\title{
Groundwater Monitoring Plan for the Solid Waste Landfill
}

\author{
J. W. Lindberg
}

C. J. Chou

October 2000

Prepared for the U.S. D epartment of Energy under Contract DE-AC06-76RL01830 


\section{DISCLAIMER}

This report was prepared as an account of work sponsored by an agency of the United States Government. Reference herein to any specific commercial product, process, or service by trade name, trademark, manufacturer, or otherwise does not necessarily constitute or imply its endorsement, recommendation, or favoring by the United States Government or any agency thereof, or Battelle Memorial Institute.

\section{PACIFIC NORTHWEST NATIONAL LABORATORY \\ operated by \\ BATTELLE \\ for the \\ UNITED STATES DEPARTMENT OF ENERGY \\ under Contract DE-AC06-76RL01830}

Printed in the United States of America

Available to DOE and DOE contractors from the

Office of Scientific and Technical Information, P.O. Box 62, Oak Ridge, TN 37831;

prices available from (615) 576-8401.

Available to the public from the National Technical Information Service,

U.S. Department of Commerce, 5285 Port Royal Rd., Springfield, VA 22161

This document was printed on recycled paper. 


\title{
Groundwater Monitoring Plan for the Solid Waste Landfill
}

\author{
J. W. Lindberg \\ C. J. Chou
}

October 2000

Prepared for

the U.S. Department of Energy

under Contract DE-AC06-76RL01830

Pacific Northwest National Laboratory

Richland, Washington 99352 


\section{Summary}

The Solid Waste Landfill (SWL) is regulated by the Washington State Department of Ecology under WAC 173-304. Between 1973 and 1976, the landfill received primarily paper waste and construction debris, but it also received asbestos, sewage, and catch tank liquid waste. Groundwater monitoring results indicate the SWL has contaminated groundwater with volatile organic compounds and possibly metals at levels that exceed regulatory limits. DynCorp, Tri-Cities, Inc. operates the facility under an interim closure plan (final closure plan will be released shortly). Pacific Northwest National Laboratory (PNNL) monitors groundwater at the site.

This monitoring plan includes well and constituent lists, and summarizes sampling, analytical, and quality control requirements. Changes from the previous monitoring plan include elimination of two radionuclides from the analyte list and some minor changes in the statistical analysis.

Existing wells in the current monitoring network only monitor the uppermost portion of the uppermost aquifer. Therefore, two new downgradient wells and one existing upgradient well are proposed to determine whether groundwater waste constituents have reached the lower portion of the uppermost aquifer. The proposed well network includes three upgradient wells and ten downgradient wells. The wells will be sampled quarterly for 14 analytes required by WAC 173-304-490 plus volatile organic compounds and filtered arsenic as site-specific analytes.

Upgradient Wells:

Downgradient Wells:

Analytes Required By WAC 173-304-490:
699-26-35A

699-24-35

699-26-35C (Proposed Existing Deeper Well)

699-25-34C

699-24-34A

699-24-34B

699-24-34C

$699-23-34 \mathrm{~A}$

699-23-34B

699-22-35

699-24-33

Two Proposed New Deeper Wells

$\begin{array}{ll}\text { Temperature } & \text { Sulfate } \\ \text { Specific Conductance } & \text { Filtered Iron } \\ \mathrm{pH} & \text { Filtered Zinc } \\ \text { Chloride } & \text { Filtered Manganese } \\ \text { Nitrate } & \text { Chemical Oxygen Demand } \\ \text { Nitrite } & \text { Total Organic Carbon } \\ \text { Ammonium } & \text { Total Coliform }\end{array}$

iii 
Site-Specific Analytes:

Volatile Organic Compounds

Filtered Arsenic

The proposed monitoring well network is designed to

- represent the quality of background groundwater quality that has not been affected by the SWL (sample and analyze groundwater from upgradient wells)

- represent the quality of groundwater passing the point of compliance (sample and analyze groundwater from downgradient wells)

- determine whether downgradient concentrations of groundwater constituents specifically required by government regulations are statistically increased over background concentrations

- determine whether concentrations of other groundwater constituents of concern (volatile organic compounds) have exceeded groundwater quality criteria (performance standards). 


\section{Contents}

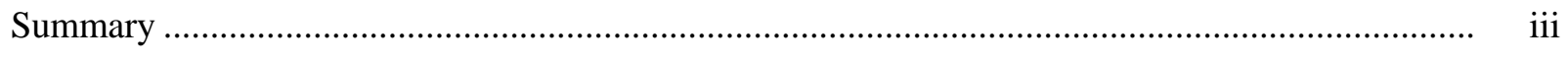

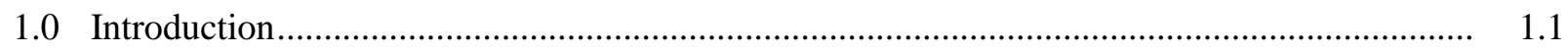

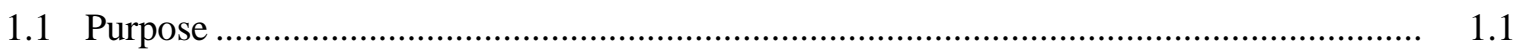

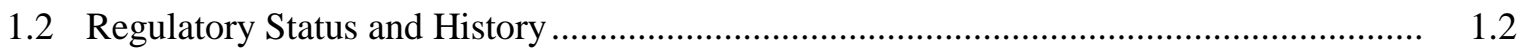

2.0 Description of the Solid Waste Landfill ................................................................. 2.1

2.1 Physical Structure and Operational History .......................................................... 2.1

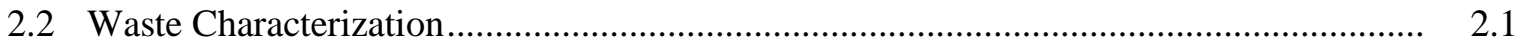

2.2.1 Waste Types and Inventory ................................................................... 2.1

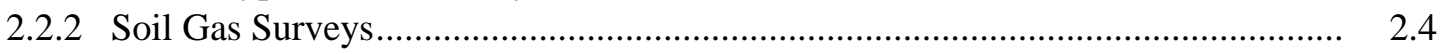

2.2.3 In Situ Gas Monitoring During Drilling .......................................................... 2.4

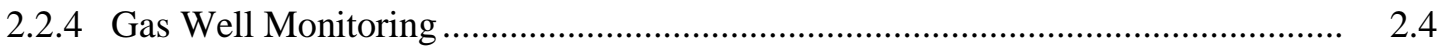

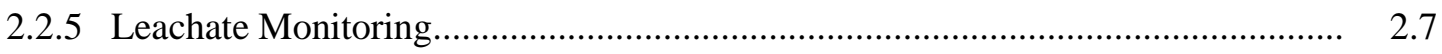

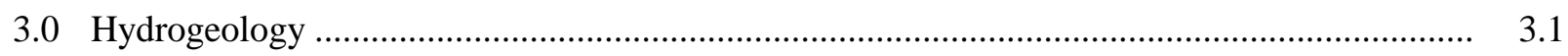

3.1 Physical Hydrogeology ..................................................................................... 3.1

3.2 Summary of Groundwater Monitoring Results ....................................................... 3.3

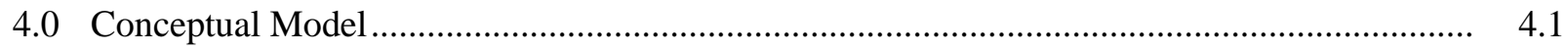

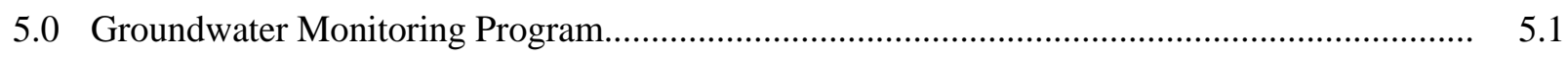

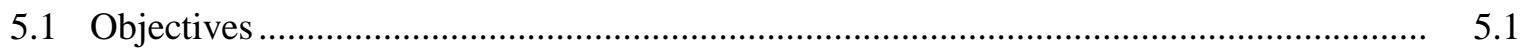

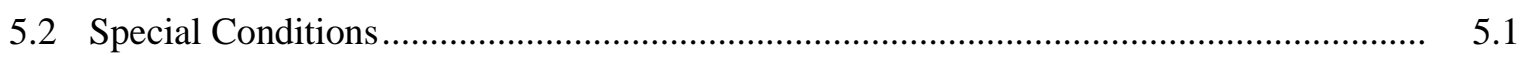

5.3 Sampling and Analysis Plan ............................................................................ 5.1

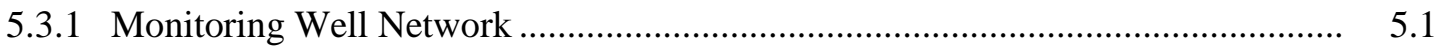

5.3.2 Constituent List and Sampling Frequency..................................................... 5.3

5.3.3 Groundwater Parameter Analysis Method Detection Limit ................................ 5.4

5.3.4 Determination of Groundwater Flow............................................................. 5.4

5.3.5 Sampling and Analysis Protocol.................................................................... 5.6

5.3.6 Quality Assurance and Quality Control.......................................................... 5.7 
6.0 Data Management, Evaluation, and Reporting ..................................................... 6.1

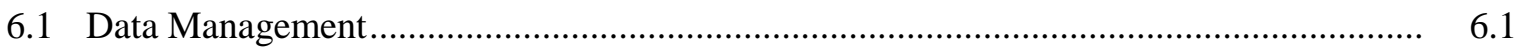

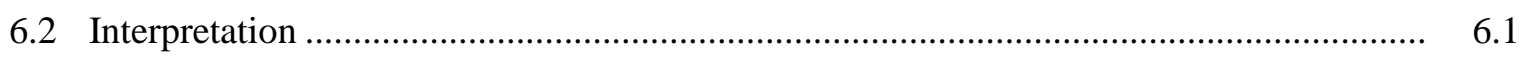

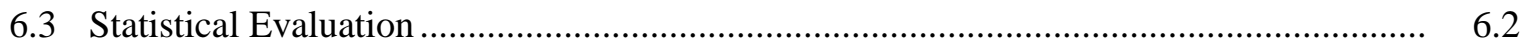

6.3.1 Background Summary Statistics.................................................................. 6.2

6.3.2 Testing the Assumption of Normality of Data.................................................. 6.2

6.3.3 Re-Establish Background Levels...................................................................... 6.4

6.3.4 Comparisons with Groundwater Performance Standards .................................... 6.6

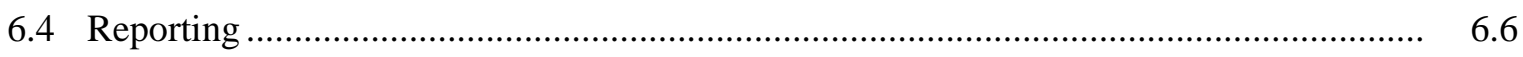

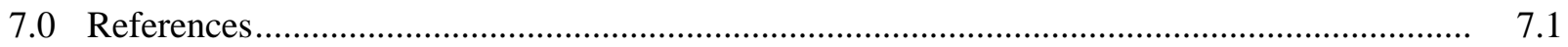

Appendix A - Leachate Monitoring Results....................................................................... A. 1

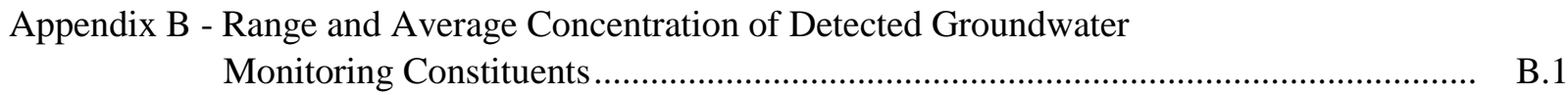

Appendix C - Construction Details of the Wells in the Monitoring Network................................ C.1 


\section{Figures}

1.1 Regulated Units on the Hanford Site Requiring Groundwater Monitoring ........................... 1.2

2.1 Map of the Solid Waste Landfill and Nonradioactive Dangerous Waste Landfill ................... 2.2

2.2 Monitoring Well Locations for Nonradioactive Dangerous Waste Landfill and Solid

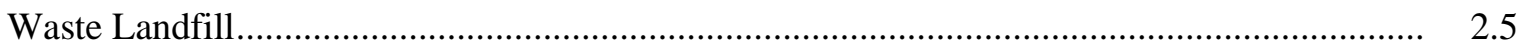

2.3 Location of Soil Gas Monitoring Stations at the Perimeter of the Solid Waste Landfill........... 2.6

3.1 Stratigraphic Column at the Nonradioactive Dangerous Waste Landfill and Solid Waste Landfill and Associated Hydrogeology .............................................................................. 3.2

3.2 Water-Table Map for Nonradioactive Dangerous Waste Landfill/Solid Waste Landfill, June 1998

\section{Tables}

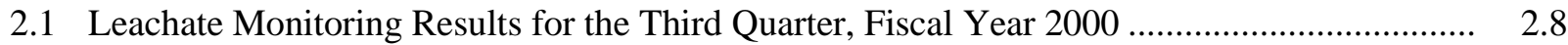

5.1 Groundwater Monitoring Wells in the Solid Waste Landfill Monitoring Network.................. 5.2

5.2 Groundwater Quality Criteria for Solid Waste Landfill Groundwater Waste Parameters and Associated Method Detection Limits

6.1 Background Summary Statistics for the Monitoring Constituent Data for the Solid Waste Landfill.

6.2 Results of Shapiro and Francia Test for Normality and Background Threshold Values for the Solid Waste Landfill

6.3 Groundwater Quality Criteria 


\subsection{Introduction}

The Solid Waste Landfill (SWL) is located in the center of the U.S. Department of Energy's (DOE's) Hanford Site in southeastern Washington State (Figure 1.1). The landfill received primarily paper waste and construction debris, but also some asbestos and sewage waste. The Nonradioactive Dangerous Waste Landfill (NRDWL), which is regulated and monitored separately, is adjacent to the SWL on the north side. The Washington State Department of Ec ology (Ecology) regulates the SWL under WAC 173-304, Washington Solid Waste Regulations. DynCorp, Tri-Cities, Inc. (DYN), under a contract to Fluor Hanford, Inc., is responsible for post-operation administration of the SWL. Currently the site is operating under an interim closure plan. The final closure plan is expected in the fall 2000.

Pacific Northwest National Laboratory (PNNL) ${ }^{1}$ conducts groundwater monitoring at the SWL. The existing monitoring network includes two upgradient wells (one shared with the NRDWL) and eight downgradient wells. The wells are sampled quarterly for a list of constituents specified by WAC 173-304-490 plus various site-specific constituents.

The monitoring network (with the possible exception of the two proposed new wells) and the frequency of sampling will remain the same as in the past. However, the statistical analysis has been changed slightly. The downgradient concentrations of volatile organic compounds will no longer be compared to background (upgradient) data, but the downgradient values will be directly compared to groundwater performance standards. Required WAC 173-304-490(2)(d) constituents will continue to be compared with background values and only compared to the performance standards when downgradient values exceed background limits. Other changes in statistical techniques include a different method to determine the goodness of fit for the distribution of the background data. Some elective constituents will no longer be analyzed for SWL objectives because they are covered under other groundwater monitoring programs. This plan proposes installation of two new downgradient wells to determine whether groundwater waste constituents have reached the lower portion of the uppermost aquifer. Existing wells only monitor the uppermost portion of the uppermost aquifer.

\subsection{Purpose}

The purpose of this plan is to present a groundwater monitoring program to determine the impact of waste disposal at the SWL on the quality of groundwater in the uppermost and interconnected aquifers underlying the facility, as required in WAC 173-304-490. This document supersedes all previous monitoring plans (DOE 1986; Fruland et al. 1989; Hodges 1994). Hodges 1996 incorporated two new wells suggested in Hodges 1994 into the monitoring network. The monitoring program proposed in this document is based on current conceptualization of the site and is consistent with data collected during 13 years of monitoring the site.

\footnotetext{
${ }^{1}$ Pacific Northwest Laboratory is operated by Battelle for the U.S. Department of Energy.
} 


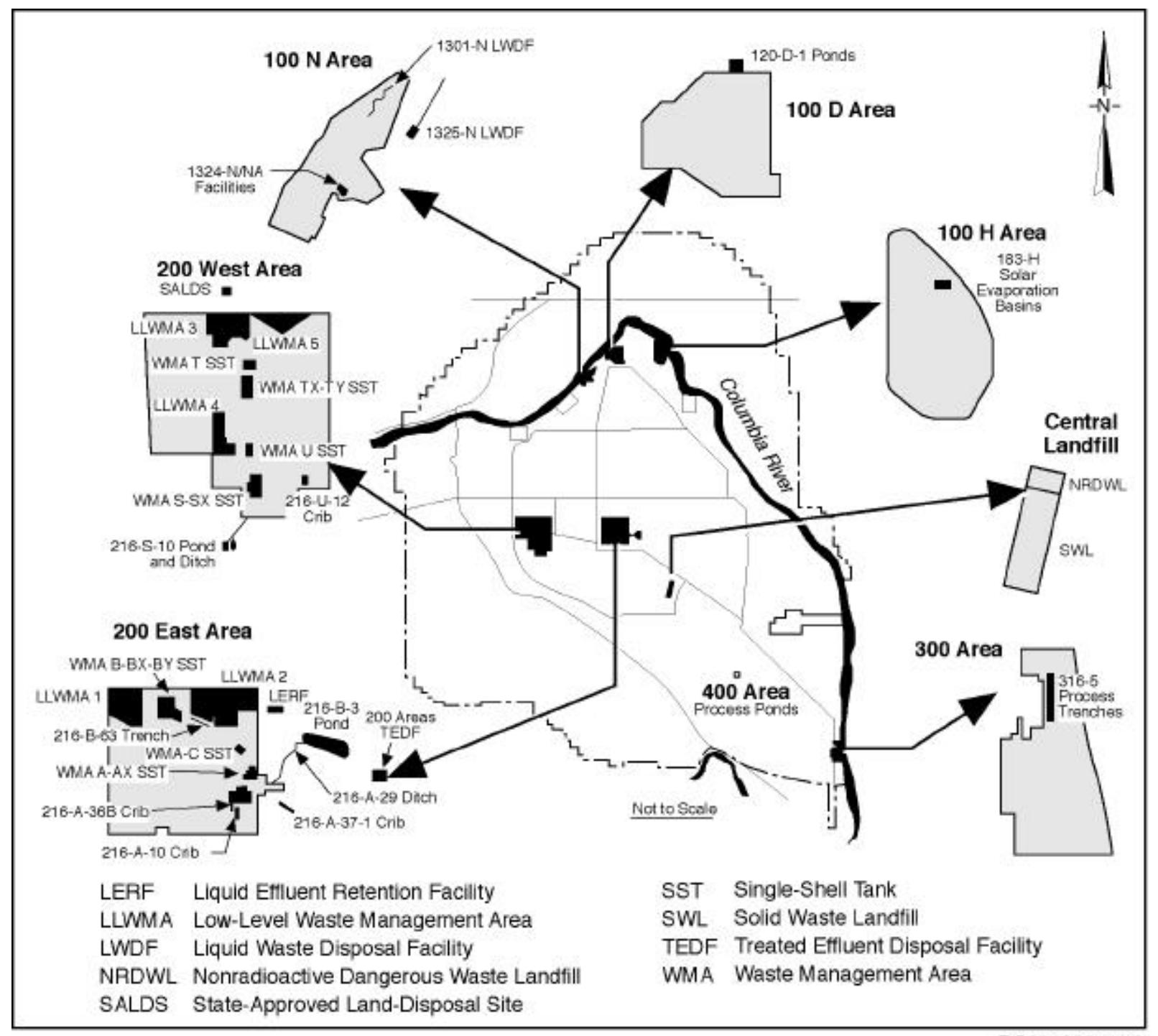

RG98120214.13

Figure 1.1. Regulated Units on the Hanford Site Requiring Groundwater Monitoring

\subsection{Regulatory Status and History}

The SWL is regulated by Washington Administrative Code (WAC 173-304), under which the regulatory agency is the Benton-Franklin Public Health Department. The U.S. Department of Energy, Richland Operations Office (RL) submitted a permit application (to continue operations at the SWL) to the BentonFranklin Public Health District in January of 1991 (DOE 1991a). The permit application was rejected because there was sufficient evidence to suggest that the SWL had contaminated groundwater. As a result of subsequent negotiation between the Benton-Franklin Public Health Department and Ecology, Ecology accepted responsibility for regulation of the SWL. 
RL submitted a revised permit application to Ecology in 1993 (DOE 1993a). Ecology reviewed the revised permit application and issued a letter to RL requesting that a corrective action program be established for the SWL. ${ }^{2}$ The letter further requested that a corrective action plan meeting the requirements of WAC 173-304-490(2)(j), be submitted to Ecology by September 30, 1994. RL subsequently requested a two-month extension, which moved the due date to November 30, 1994. A corrective action plan meeting the requirements of WAC 173-304-490(2)(j) was written (DOE 1994a) and submitted to Ecology by November 30, 1994. The corrective action plan was accepted by Ecology. However, the corrective action plan was never implemented due to other site activities having higher priority. The SWL was permanently closed in 1996 and continues to be regulated by the interim closure plan (DOE 1996a) and the requirements of WAC 173-304.

${ }^{2}$ Letter from F. Ma, Washington State Department of Ecology, to J. E. Rasmussen, DOE-RL, dated June 23, 1994, Corrective Action Program Requirements, Scale Construction, Operational Plan, and Lysimeter Installation, Hanford Site Solid Waste Landfill. 


\subsection{Description of the Solid Waste Landfill}

This section discusses the physical structures, operational history, and waste characteristics at the SWL and is largely taken from Conceptual Model for the SWL (BHI 1997) unless otherwise noted.

\subsection{Physical Structure and Operational History}

The SWL is located about 5.6 kilometers southeast of the 200 East Area (see Figure 1.1) and occupies approximately 26 hectares (65 acres). It consists of a series of parallel trenches that vary in length from 168 to 200 meters, are 5 meters wide at the base (single width) to 16 meters wide at the base (double width), and are 6 meters deep (Figure 2.1). The general method of landfilling used at the SWL was the trench method, where waste was placed in the trenches and covered with soil. Asbestos debris was segregated from general sanitary waste and placed in the single-wide trenches. Sanitary waste usually went into double-wide trenches. At the end of a typical day of operation, a portion of the spoil pile was pushed over the refuse to form the daily cover, which was typically 15 to 30 centimeters thick. After a trench was filled, the remaining spoil pile was bulldozed over the trench to form an operational cover.

The site was originally designated as the Central Landfill. The Central Landfill began operation in 1973 to receive sanitary waste, asbestos, and construction and demolition debris from Hanford Site operations. The landfill also received sewage and liquid waste (inclu ding wash-water waste from the bus garage) beginning in 1974. The Central Landfill (original area 154,000 square meters) was subdivided into two units for operational purposes. In 1975, the northern-most unit (40,000 square meters) of the Central Landfill was isolated to dispose of asbestos waste material and non-radioactive chemical waste. This northern unit was designated formally as the NRDWL because of the presence of regulated dangerous waste. It is regulated as a RCRA land disposal facility and has a separate groundwater monitoring program (Lindberg and Hartman 1999). The remainder of the Central Landfill (114,000 square meters) is designated as the SWL. In 1982, the Central Landfill was expanded 154,000 square meters to the south. This was dubbed the Phase II Area (the former area then became the Phase I Area). The total area of the Central Landfill became 268,000 square meters (see Figure 2.1).

After closure of the SWL in March 1996, an "interim cover" (which was the operational cover during operation of the SWL) was placed over the SWL trenches. The cover consists of native, well-graded sand with a very low percentage of fines (DOE 1996a). The soil was distributed evenly and leveled in order to minimize topographic lows, which could colle ct precipitation and runoff.

\subsection{Waste Characterization}

\subsubsection{Waste Types and Inventory}

Both solid and liquid waste was disposed at the SWL. There is no evidence that the solid waste contained volatile organic compounds. Analysis of one type of liquid waste indicates that it contained carbon tetrachloride, 1,1,1-trichloroethane, trichloroethene, and tetrachloroethene. Radioactive waste was not disposed in the SWL. 


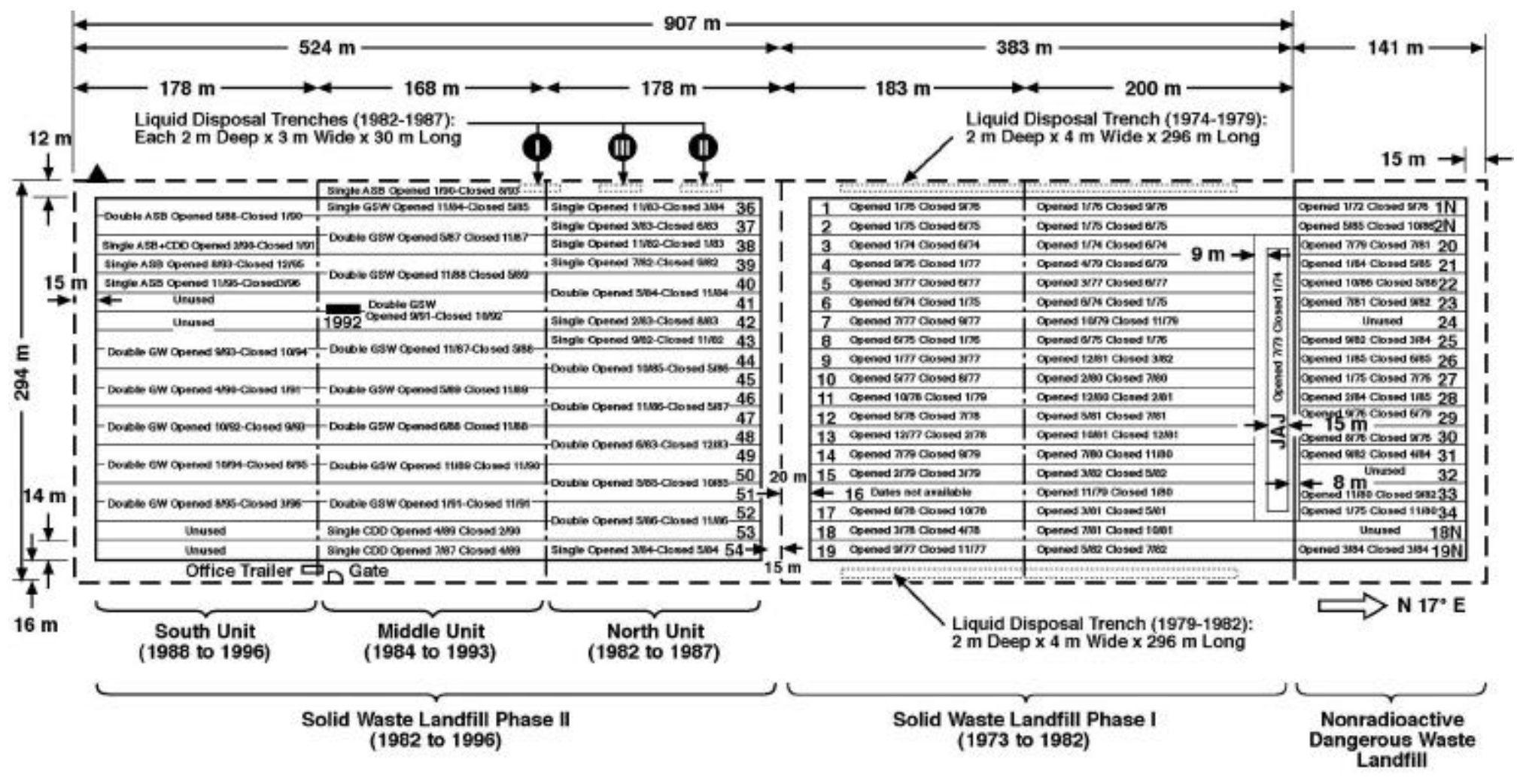

\section{Legend}

\section{--- Fence}

- - Panel Boundary

Trench Boundary

A Survey Marker (N22618.14 W/35398.87)
ASB

GSW

CDD

GW

\section{Asbestos Waste}

General Solid Waste

Construction/Demolition Debris

General Solid Waste and

Construction/Demolition Debris

E9706105.2a

1992 Basin Lysimeter with

Figure 2.1. Map of the Solid Waste Landfill and Nonradioactive Dangerous Waste Landfill (from BHI 1997) 
The types of waste disposed at the SWL include office waste, construction/demolition debris, asbestos material, bulky items, and miscellaneous waste, based on waste receipts (DOE 1993a, 1996a):

- Office waste comprises approximately $40 \%$ of the total volume of waste disposed in the SWL, and most of the office waste is waste paper products.

- Construction/demolition debris, approximately $30 \%$ of the total waste, is from construction activities and from the renovation of buildings including waste wood products like pallets.

- Asbestos material (non-radioactive or non-hazardous asbestos or material containing asbestos) accounts for approximately $10 \%$ by volume of all waste disposed at the SWL. Most of this material came from the demolition or renovation activities at Hanford Site buildings.

- Bulky items include large items of refuse such as appliances and office furniture that do not fit into solid waste collection containers. Approximately $10 \%$ of the total waste volume at SWL includes material in the bulky items category.

- Miscellaneous waste at the SWL includes garbage from Hanford Site personnel lunches, industrial waste such as packing and empty containers, medical waste from first aid stations, and various inert materials. The volume of the total estimated to be miscellaneous waste is $10 \%$.

From 1973 to 1987, sewage and 1100 Area catch tank liquid was discharged to the SWL in separate shallow trenches. The sewage originated from portable toilets and septic tanks. Catch tank liquid from the 1100 Area heavy equipment garage and bus shop also was disposed in these trenches from 1985 to 1987. Chemical analysis of the 1100 Area catch liquid showed that the following were detected (DOE 1993a):

- carbon tetrachloride

- 1,1,1-trichloroethane

- trichloroethene

- tetrachloroethene.

It is possible, but unlikely, that these organic compounds were in the form of dense nonaqueous phase liquids (DNAPLs). Sewage and other liquids were not accepted at the SWL after 1987, and disposal of radioactive and dangerous waste was always prohibited at the SWL.

Based on waste receipts, the SWL received approximately 400,266 cubic meters of solid waste and 14, 496 cubic meters of asbestos waste during the years 1973 to 1995. An estimated 3,800,000 to 5,700,000 liters of sewage were discharged to the liquid trenches from 1975 to April 1987. For the two years catch tank waste liquid was disposed at the SWL, the estimated total volume of catch tank waste liquid disposed is 380,000 liters (DOE 1996a). 


\subsubsection{Soil Gas Surveys}

A soil gas survey was conducted at the SWL from June 1988 through February 1989 to determine the areal extent of chlorinated hydrocarbons (Evans et al. 1989a). Soil gas samples were collected from probes emplaced at depths of 1.2 to 1.8 meters at sites 30 meters apart. Probes were more closely spaced near the three short disposal trenches used for 1100 Area wash-water disposal to better define the spatial distribution of contaminants at their presumed source. The survey found detectable concentrations of 1,1,1-trichloroethane, trichloroethene, tetrachloroethene, 1,1-dichloroethane, carbon tetrachloride, carbon dioxide, and methane. 1,1,1-trichloroethane, tetrachloroethene, and trichloroethene were detected as far as 130 meters west and 115 meters east of the SWL.

Results of the June 1988 to February 1989 soil gas survey show that the areas of relatively high soil gas concentrations generally do not coincide with the locations of the known liquid disposal trenches. Because it is reasonable to assume that the highest soil gas concentrations will persist at the contaminant source, these data suggest that there may be other, undocumented (completely unknown) sources of volatile organic compounds within the SWL area.

\subsubsection{In Situ Gas Monitoring During Drilling}

In situ soil gas samples were collected while drilling groundwater monitoring well 699-22-35 and 699-23-34B (Figure 2.2) at the southeast corner of the SWL in 1993 and 1994 (Hodges 1997). The soil gas samples were collected using a membrane sampling system that allows sampling at discrete intervals within the borehole. Samples were collected at approximately every 6 meters at each borehole. The only target analyte detected in the borehole samples was carbon tetrachloride. All 11 borehole samples contained detectable quantities of carbon tetrachloride in concentrations ranging from $0.1 \mathrm{ppmv}$ to $1.4 \mathrm{ppmv}$.

\subsubsection{Gas Well Monitoring}

Sixteen soil gas probes were installed at eight locations (Figure 2.3) around the perimeter of the SWL in September 1993 to monitor concentrations of landfill gases (methane, carbon dioxide, and oxygen) in accordance with WAC 173-304 and sample (field-screening analysis) for chlorinated hydrocarbons. ${ }^{1}$ Two dedicated soil-gas probes were installed at each monitoring location, one at a depth of approximately 2.7 meters (labeled with an A) and a second at a depth of 4.6 meters (labeled with a B).

While conducting the field screenings for chlorinated hydrocarbons at four times (four phases) during the period 1993 to 1997, the primary contaminant detected was 1,1,1-trichloroethane. The highest concentration was consistently detected at probe SWL-08B (4.6-meter depth) on the south side of the SWL. The second highest concentrations were at probe SWL-02B on the east side and probe SWL-08A. The concentrations of 1,1,1-trichloroethane decreased during the field screenings at all three of these locations. During 1993, low levels of tetrachloroethene (0.02 to $0.19 \mathrm{ppmv})$ were detected at seven of the

\footnotetext{
${ }^{1}$ Internal memo from R. B. Kerkow to R. R. Knight, Bechtel Hanford, Inc., Richland, Washington, dated December 17, 1993, Solid Waste Landfill-Methane Monitoring (Phase I and II).
} 


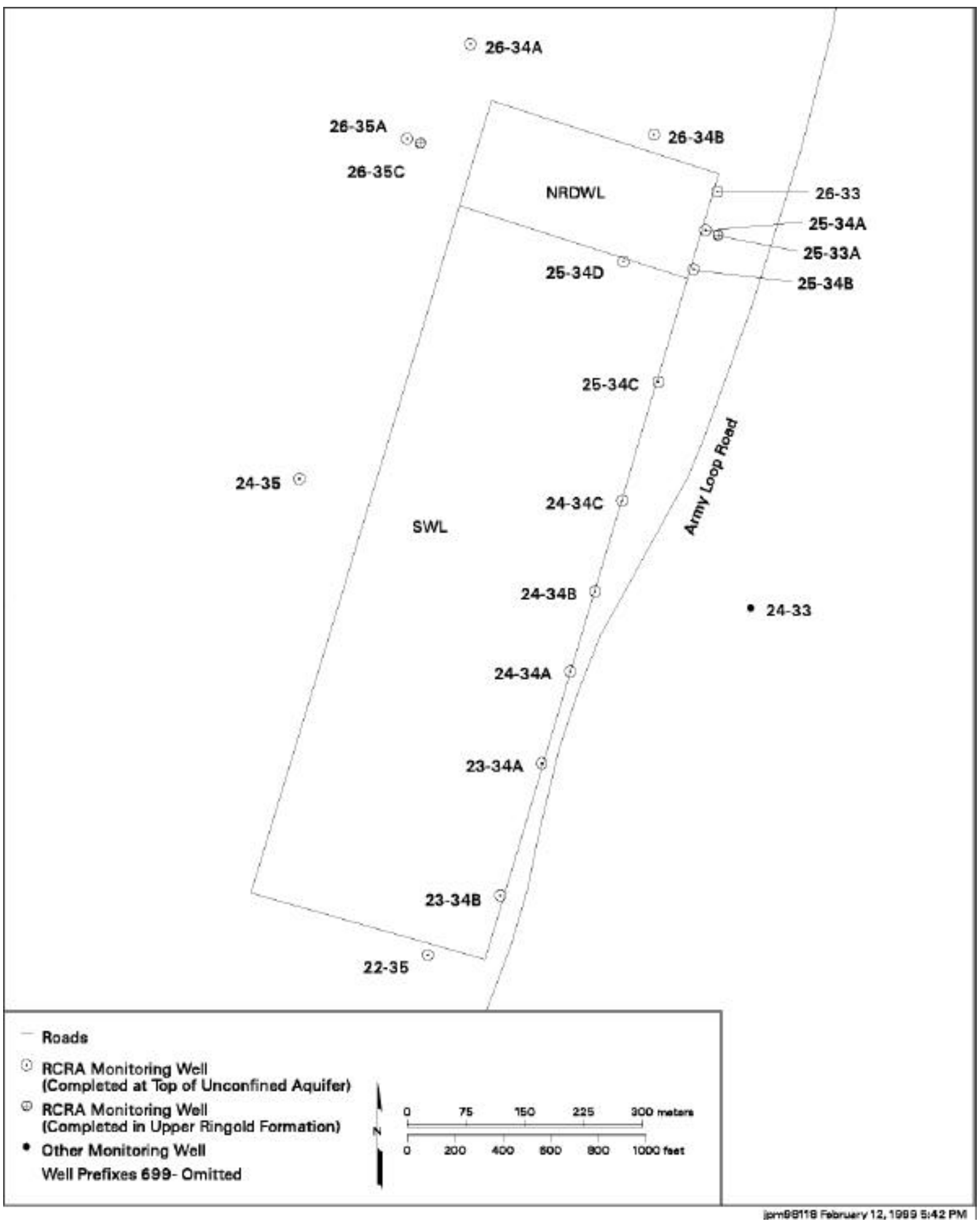

Figure 2.2. Monitoring Well Locations for Nonradioactive Dangerous Waste Landfill and Solid Waste Landfill 


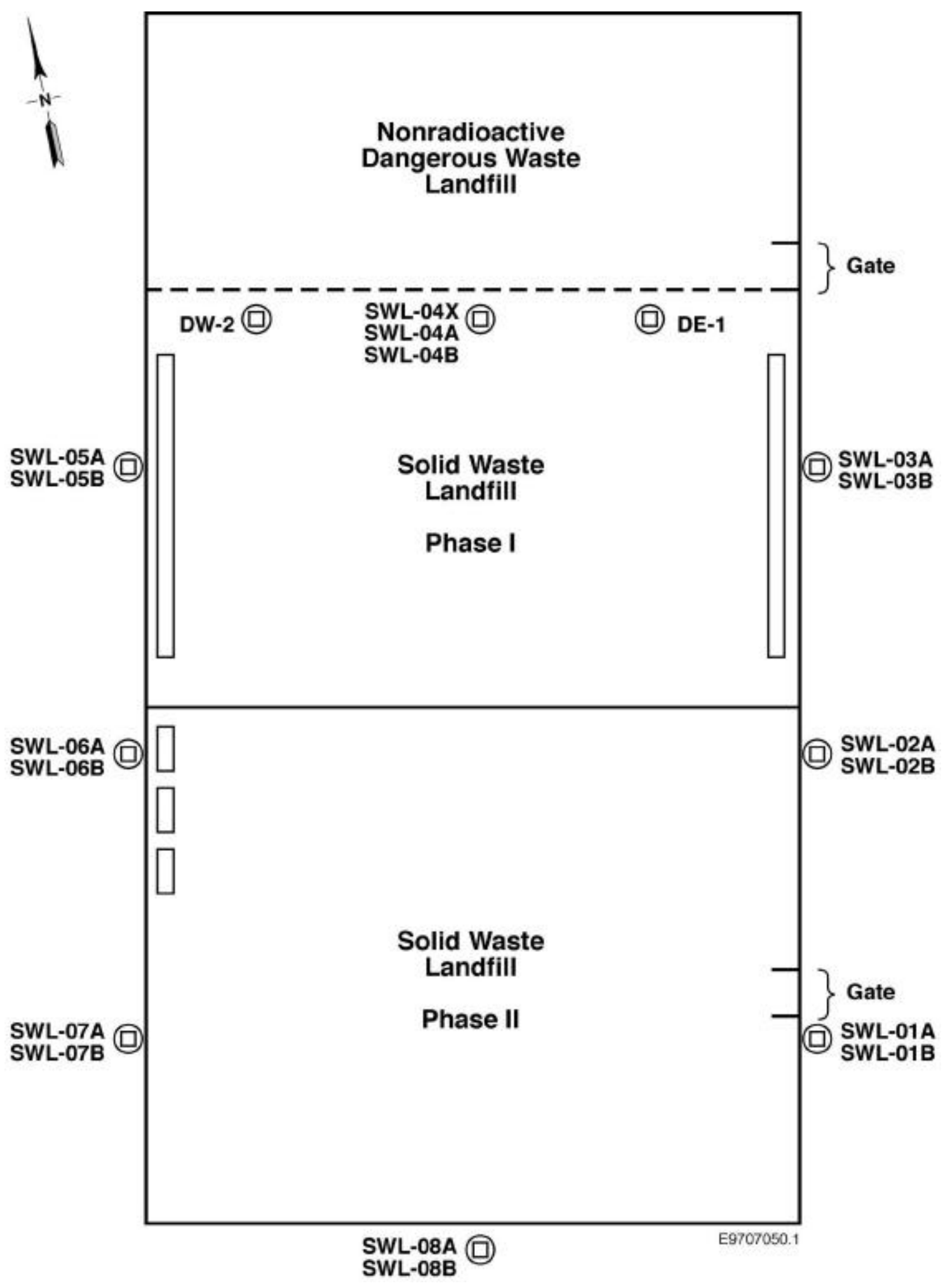

Figure 2.3. Location of Soil Gas Monitoring Stations at the Perimeter of the Solid Waste Landfill (from BHI 1997) 
probes and were not detected subsequently. In 1993, trichloroethene was detected at concentrations ranging from $<0.010$ to $0.045 \mathrm{ppmv}$ at three probes, and during 1997 was detected at trace levels at four of the probes.

\subsubsection{Leachate Monitoring}

In 1992, a basin lysimeter was installed beneath the Phase II area middle unit at the southern end of double trench 41 and 42 (see Figure 2.1). This trench was filled from north to south and closed in October 1992. The lysimeter is 21 meters long, 4.6 meters wide on one end and 3.9 meters on the other end, with a collection area of 88 square meters. A discharge pipe continuously drains the leachate by gravity flow from the basin to a nearby collection sump. The lysimeter is designed to collect leachate generated by water infiltrating through the overlying waste trench and to drain the leachate to a collection system. The leachate quality and quantity are analyzed to evaluate the impact that leachate would have on groundwater quality.

Starting in 1996, the sump associated with the lysimeter began accumulating leachate (indicating a four-year lag time between occurrence of precipitation at the surface and appearance of that same water as leachate). Initially the collection rate was 19 liters per day, but reached 38 liters per day by 1997. Leachate samples were analyzed for the indicator parameters (specific conductance, $\mathrm{pH}$, chloride, nitrate, nitrite, ammonium ion, sulfate, chemical oxygen demand, and total organic carbon) ${ }^{1}$ as specified in the landfill permit application (DOE 1993a). In addition, the samples were also analyzed for the constituents identified in WAC 173-351-990, Appendices I and II, and for four volatile organic compounds (1,1,1-trichloroethane; 1,1-dichloroethane; tetrachloroethene; and trichloroethene) that had been detected in groundwater beneath the landfill. ${ }^{2}$ After these initial rounds of sampling and analysis in 1996, a sampling and analysis plan for leachate was developed that is consistent with the provisions of the SWL interim closure plan and the permit application (DOE 1996a, 1993a). In 1997, the plan was modified to monitor specific analytes quarterly and to include all analytes per WAC 173-351-990, Appendices I and II, annually to verify no change in other analytes (Sayler 1997).

Of the primary contaminants of concern, 1,1,1-trichloroethane; 1,1-dichloroethane; tetrachloroethene; cis-1,2- dichloroethene; and trichloroethene were detected in the early rounds of sampling in 1996 and 1997. Both dichloroethane and tetrachloroethene concentrations in these early analyses exceeded the groundwater quality criteria of WAC 173-200. Several of the indicator parameters, some volatile organic constituents, and some metals continue to be above the groundwater quality criteria and/or maximum contaminant levels for public water supplies established in WAC 246-290. However, 1,1-dichloroethane and tetrachoroethene (primary contaminants of concern in the earlier analyses) are no longer detected in the leachate. Table 2.1 shows leachate monitoring results for several key constituents for the third quarter

\footnotetext{
${ }^{1}$ Letter 9653595 from Westinghouse Hanford Company to U.S. Department of Energy, Richland Operations Office, Richland, Washington, dated August 16, 1996, Leachate Test Results from Solid Waste Landfill.

${ }^{2}$ Letter 9653595 R1 from Westinghouse Hanford Company to U.S. Department of Energy, Richland Operations Office, Richland, Washington, dated September 27, 1996, Leachate Test Results from Solid Waste Landfill.
} 
Table 2.1. Leachate Monitoring Results for the Third Quarter, Fiscal Year 2000 (Data provided by DYN)

\begin{tabular}{||l|c|c|c||}
\hline \multicolumn{1}{|c|}{ Parameter } & Result & $\mathrm{GWQC}^{(\mathrm{a})}$ & $\mathrm{MCL}^{(\mathrm{b})}$ \\
\hline \hline $\mathrm{pH}$ & 7.39 & $6.5-8.5$ & $\mathrm{NA}$ \\
\hline Conductivity & $1,986 \mu \mathrm{S} / \mathrm{cm}$ & $\mathrm{NA}$ & $700 \mu \mathrm{S} / \mathrm{cm}$ \\
\hline Sulfate & $<20.2 \mathrm{mg} / \mathrm{L}$ & $250 \mathrm{mg} / \mathrm{L}$ & $250 \mathrm{mg} / \mathrm{L}$ \\
\hline Chloride & $236.2 \mathrm{mg} / \mathrm{L}$ & $250 \mathrm{mg} / \mathrm{L}$ & $250 \mathrm{mg} / \mathrm{L}$ \\
\hline Total Dissolved Solids & $1,361 \mathrm{mg} / \mathrm{L}$ & $500 \mathrm{mg} / \mathrm{L}$ & $\mathrm{NA}$ \\
\hline Arsenic & $15.6 \mu \mathrm{g} / \mathrm{L}$ & $0.05 \mu \mathrm{g} / \mathrm{L}$ & $50 \mu \mathrm{g} / \mathrm{L}$ \\
\hline Barium & $447 \mu \mathrm{g} / \mathrm{L}$ & $1,000 \mu \mathrm{g} / \mathrm{L}$ & $2,000 \mu \mathrm{g} / \mathrm{L}$ \\
\hline Mercury & $<0.125 \mu \mathrm{g} / \mathrm{L}$ & $2 \mu \mathrm{g} / \mathrm{L}$ & $2 \mu \mathrm{g} / \mathrm{L}$ \\
\hline Manganese & $2,850 \mu \mathrm{g} / \mathrm{L}$ & $50 \mu \mathrm{g} / \mathrm{L}$ & $50 \mu \mathrm{g} / \mathrm{L}$ \\
\hline Nickel & $233 \mu \mathrm{g} / \mathrm{L}$ & $\mathrm{NA}$ & $100 \mu \mathrm{g} / \mathrm{L}$ \\
\hline Cadmium & $<0.25 \mu \mathrm{g} / \mathrm{L}$ & $10 \mu \mathrm{g} / \mathrm{L}$ & $5 \mu \mathrm{g} / \mathrm{L}$ \\
\hline Copper & $4.01 \mu \mathrm{g} / \mathrm{L}$ & $1,000 \mu \mathrm{g} / \mathrm{L}$ & $\mathrm{NA}$ \\
\hline Selenium & $2.5 \mu \mathrm{g} / \mathrm{L}$ & $10 \mu \mathrm{g} / \mathrm{L}$ & $50 \mu \mathrm{g} / \mathrm{L}$ \\
\hline Zinc & $584 \mu \mathrm{g} / \mathrm{L}$ & $5,000 \mu \mathrm{g} / \mathrm{L}$ & $5,000 \mu \mathrm{g} / \mathrm{L}$ \\
\hline 1,4-Dioxane & $100 \mu \mathrm{g} / \mathrm{L}$ & $7 \mu \mathrm{g} / \mathrm{L}$ & $\mathrm{NA}$ \\
\hline 1,4-Dichlorobenzene & $5 \mu \mathrm{g} / \mathrm{L}$ & $4 \mu \mathrm{g} / \mathrm{L}$ & $\mathrm{NA}$ \\
\hline $\begin{array}{l}\text { (a) Groundwater quality criteria from WAC } 173-200 . \\
\text { (b) Maximum contaminant level from WAC } 246-290 .\end{array}$ \\
\hline \multicolumn{4}{|l|}{} \\
\hline
\end{tabular}

of fiscal year 2000. (Appendix A is a summary of all of the SWL leachate analysis results for the first quarter of fiscal year 1997 through the third quarter of fiscal year 2000.) Total dissolved solids, arsenic, manganese, 1,4-dioxane, and 1,4-dichlorobenzene are equal to or exceed the groundwater quality criteria. In addition, conductivity, manganese, and nickel exceed the maximum contaminant levels. The primary contaminants of concern listed above (i.e., 1,1,1-trichloroethane; 1,1- dichloroethane) were below the detection limits in the second quarter of fiscal year 2000. 


\subsection{Hydrogeology}

All of the wells at the SWL are completed in the upper portion of the uppermost aquifer with an average borehole depth of 43 meters. However, five wells at the NRDWL are deeper and provide geologic and hydrologic information to a depth of 78 meters below ground surface ( 83 meters above mean sea level). Therefore, much of what is known about the subsurface at the SWL is derived from the nearby wells at the NRDWL. The geology and hydrology of the SWL and the NRDWL are described in detail by Weekes et al. (1987), Fruland et al. (1989), DOE (1993a), and Hodges (1994, 1996). The following summary is taken largely from those documents unless indicated otherwise.

\subsection{Physical Hydrogeology}

The SWL is underlain by sands and gravels of the Hanford and Ringold formations (Figure 3.1). The vadose zone is 38- to 40-meters thick and consists of sand and silty gravelly sand grading downward to sandy gravel and gravel. The water table is near the top of a silty sand unit of the Hanford formation. Saturated sediment is composed of the following units:

- Saturated Hanford formation sediment: gravelly sand to sandy gravel, 18 -meters thick; estimated hydraulic conductivity (assuming saturated thickness of 18 meters) from field aquifer tests is approximately 500 to 1,500 meters per day.

- Upper Ringold and Ringold Formation unit E, divided into three units based on lithology and hydraulic conductivity (40- to 45 -meters thick):

- Slightly silty gravelly sand to sand, 4-meters thick; estimated horizontal hydraulic conductivity from field aquifer tests is 60 meters per day.

Hard, clayey silt (low permeability) 1- to 4 - meters thick; estimated vertical hydraulic conductivity from field aquifer tests ranges from 0.006 to 3 meters per day.

- Silty sand to sandy gravel, unknown thickness; estimated horizontal hydraulic conductivity from field aquifer tests ranges from 0.3 to 15 meters per day. This unit is probably unit $\mathrm{E}$, but there are no wells in the vicinity that fully penetrate the unit. Approximately 2 kilometers east at well 699-25-26, the Ringold Formation unit E is 40 meters thick (Lindsey 1991).

- Ringold Formation unit $\mathrm{C}$, unit B, the lower mud unit, and unit A are estimated as follows:

- Unit C, 10 meters, gravel and sandy gravel

- Overbank deposit, 20 meters, sandy silt and silty sand

- Unit B, 10 meters, gravel and sandy gravel

- Lower mud unit, 17 meters, silt and sandy silt

- Unit A, 28 meters, gravel and sandy gravel

- Top of basalt at a depth of $\sim 180$ meters. 


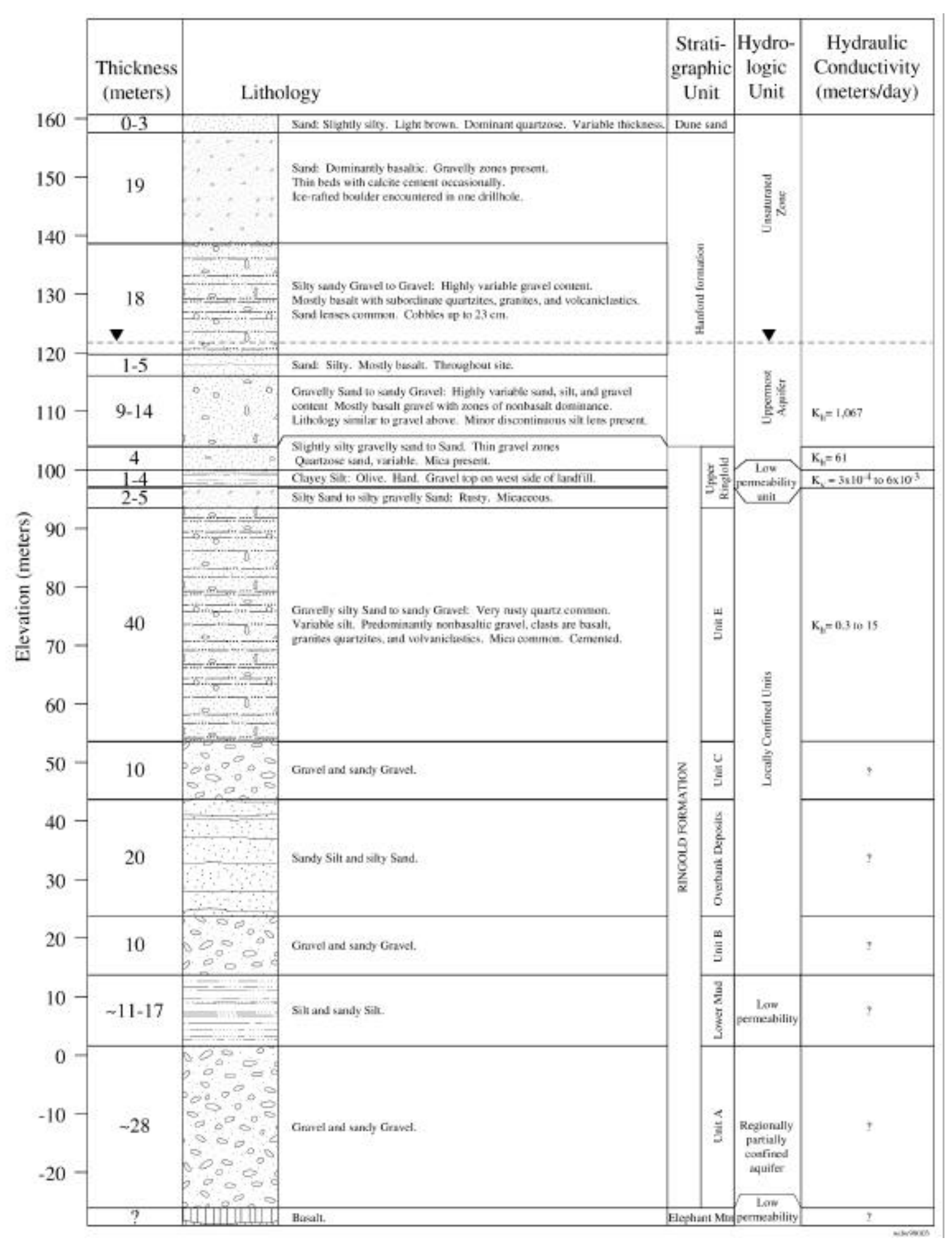

Figure 3.1. Stratigraphic Column at the Nonradioactive Dangerous Waste Landfill and Solid Waste Landfill and Associated Hydrogeology 
The uppermost aquifer is unconfined and is part of the saturated Hanford formation sediment and probably the upper portion of the Upper Ringold unit. A low-permeability unit perhaps in the lower portion of the Upper Ringold unit or in unit $\mathrm{E}$ is believed to form the base of the uppermost aquifer because the hydraulic conductivity of the aquifer base is orders of magnitude lower than the overlying sediment.

The hydraulic gradient beneath the SWL is very low because the uppermost aquifer is very transmissive. Weekes et al. (1987) reported the hydraulic gradient at the nearby NRDWL at approximately 0.00005. Previous estimates based on well data indicate that flow is generally west to east (Weekes et al. 1987, p. 43). A water-table map of the region around the SWL is shown in Figure 3.2. Assuming groundwater flows perpendicular to the equipotential lines, flow converges from the north-northeast and the southwest, and moves toward the southeast. Contaminant plumes originating in the 200 East Area move through the area from northwest to southeast, corroborate this interpretation.

Two wells at NRDWL sample the bottom of the uppermost aquifer, i.e., just above the lowpermeability unit. Heads in these wells are virtually the same as in adjacent wells completed at the top of the aquifer, indicating no significant vertical gradient (Hartman et al. 1999, Section 3.7).

Water levels beneath the SWL declined approximately 2 meters since 1988 because lower volumes of liquid waste are being discharged to the ground in the 200 Areas (see Figure 3.2 and Hartman et al. 1999, Section 3.7 and Figure 3.7-1). Based on a comparison of present levels of the water table with a hindcast water-table map (estimating water-table elevations in 1944, ERDA 1975), the water table could decline as much as an additional 2.5 to 3 meters before returning to pre-Hanford Site levels.

\subsection{Summary of Groundwater Monitoring Results}

WAC 173-304 requires that groundwater beneath solid waste landfills is monitored to determine whether or not the landfill operations have effected groundwater at the point of compliance (the perimeter fence). To comply with WAC 173-304, ten groundwater monitoring wells have been installed at the water table at two upgradient locations and eight downgradient locations (see Figure 2.2). Construction details for the SWL groundwater monitoring wells are presented in Appendix C. All but one well (699-24-33) meet the construction requirements of WAC 173-160. Well 699-24-33 was drilled in 1948 and consists of 8-inch-inside-diameter carbon steel casing that is perforated below the water table. Results from this well were used to support other well information and were not used for statistical upgradient versus downgradient comparisons. The well sampling results are also useful for providing groundwater monitoring data downgradient of the SWL between 1948 and 1987 when the other wells were constructed.

Statistical analyses of groundwater chemical data collected up to August 1988 is reported in Fruland et al. (1989). Subsequent statistical analyses are reported in RCRA annual reports and annual reports for the Hanford Site groundwater monitoring program (DOE 1991b, 1992, 1993b, 1994b, 1995, 1996b; Fruland and Lundgren 1989; Smith and Gorst 1990; Hartman and Dresel 1997, 1998; Hartman et al. 1999; and Hartman et al. 2000). 


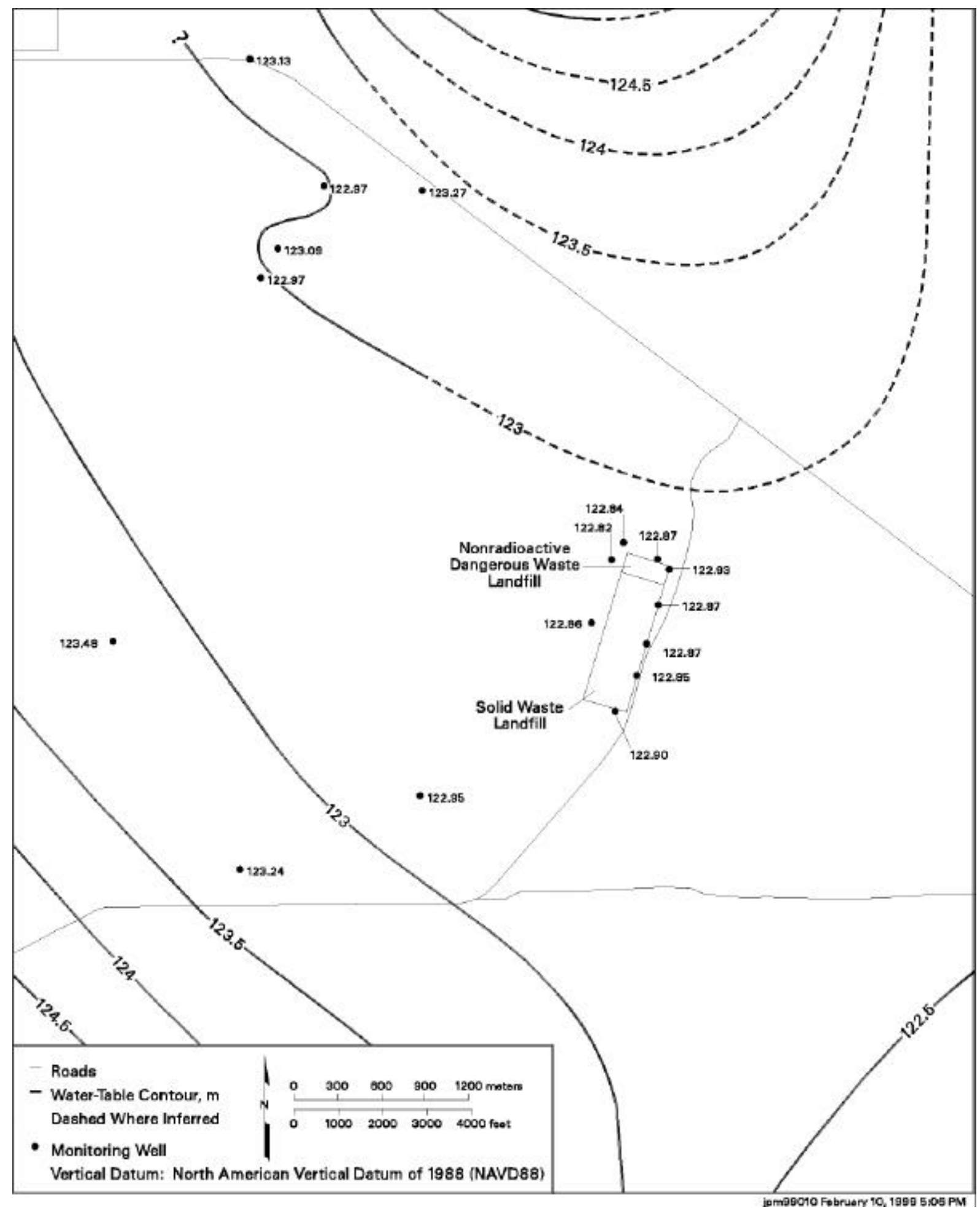

Figure 3.2. Water-Table Map for Nonradioactive Dangerous Waste Landfill/Solid Waste Landfill, June 1998 
Groundwater samples have been collected at the SWL since May 1987. Sampling continued on a quarterly basis (as required by WAC 173-304-490) through April 1990, and from August 1991 to present. Quarterly sampling was interrupted between May 1990 and August 1991 because of the loss of the analytical laboratory (DOE 1993b). Water-table elevations were measured monthly at each groundwater monitoring well through 1995, but subsequently were changed to quarterly measurements taken at the same time the wells were sampled (as required by WAC 173-304-490).

The constituent list for groundwater analyses of SWL samples consisted of those analytes required by WAC 173-304-490. In addition, total organic halogens, chlorinated hydrocarbons, gross alpha, gross beta, and tritium were included in the monitoring list as site-specific constituents. Tritium concentration was monitored to provide information on groundwater flow rates and directions. However, tritium, as well as other analytes, have been dropped from the list of SWL analytes (see Section 5.3.2).

Chlorinated hydrocarbons were included on the list of groundwater analytes because they were detected in well 699-24-33 downgradient of the SWL during a Hanford Site-wide groundwater survey in January 1986 (Hall 1988, Fruland et al. 1989). The chlorinated hydrocarbons detected were 1,1,1-trichloroethane; 1,1-dichloroethane; trichloroethene, and tetrachloroethene (Appendix B provides minimum, maximum, and average detected values for all detected analytes at the SWL). Soil gas analyses (Evans et al. 1989a, b) confirmed the presence of these four chlorinated hydrocarbons and indicated the presence (in low concentrations) of chloroform and carbon tetrachloride (see Section 2.2.2).

In addition to the routinely detected chlorinated hydrocarbons, other volatile organic compounds detected infrequently or occasionally include: 1,1,2-trichloroethane; 1,2-dichloroethane; 1,4-dichlorobenzene; 4-methyl-2-pentanone; benzene; ethylbenzene; cis-1,2- dichloroethene; trans1,2-dichloroethene; methylene chloride; toluene; and xylenes (Appendix B). Of these volatile organic compounds, only methylene chloride and 1,2-dichloroethane were detected at le vels exceeding the groundwater quality criteria (WAC 173-200). Concentrations of these two volatile organic compounds at levels exceeding their respective groundwater quality criteria were not confirmed by subsequent sampling results, and therefore, these two exceedances are considered anomalous and unrepresentative.

1,1,1-trichloroethane is one of the most commonly detected volatile organic compounds at the SWL, though the highest concentration detected was $62.5 \mu \mathrm{g} / \mathrm{L}$ at well $699-24-34 \mathrm{~B}$, which is well be low the groundwater quality criteria of $200 \mu \mathrm{g} / \mathrm{L}$ (WAC 173-200). It has been detected in all wells at the SWL including monitoring wells at the adjacent NRDWL. The concentrations of 1,1,1- trichloroethane are highest in the six groundwater monitoring wells near the southern end of the landfill (see Figure 2.2). Concentrations of 1,1,1-trichloroethane dropped steadily through 1996 and have remained steady or decreased slightly since then.

Trichloroethene was detected in downgradient monitoring wells at the SWL in concentrations as high as $8.0 \mu \mathrm{g} / \mathrm{L}$ (699-24-34B), which is above the groundwater quality criteria of $3 \mu \mathrm{g} / \mathrm{L}$ and the federal maximum contaminant levels of $5 \mu \mathrm{g} / \mathrm{L}$. The groundwater concentration pattern for trichloroethene in downgradient wells is similar to that for 1,1,1-trichloroethane where it is most concentration in the 
southern wells of the groundwater monitoring well network. Also, like 1,1,1-trichloroethane, the concentration of trichloroethene dropped steadily through 1996 and continued to drop slightly or remained steady since then.

Tetrachloroethene (sometimes called perchloroethylene - PCE) was detected in all wells at the SWL, both upgradient and downgradient. The highest detected level was $12 \mu \mathrm{g} / \mathrm{L}$ at well 699-23-34A in April 1990. Tetrachloroethene concentrations are decreasing with time but remain above the groundwater quality criteria $(0.8 \mu \mathrm{g} / \mathrm{L})$. The highest concentrations tend to occur in the downgradient wells near the southern end of the SWL. However, unlike the distribution pattern for trichloroethane and trichloroethene, concentrations of tetrachloroethene in the two most southern wells are not as high as the four wells immediately north of these two most southern wells (DOE 1993a, DOE 1994a).

1,1-dichloroethane was de tected in the downgradient monitoring wells of the SWL in concentrations as high as $7 \mu \mathrm{g} / \mathrm{L}$ (well 699-23-34A, April 1990), which is above the groundwater quality criteria of $1.0 \mu \mathrm{g} / \mathrm{L}$. The highest concentrations of 1,1-dichloroethane occur in the six southern-most downgradient wells. In one upgradient well, the concentration reached $0.4 \mu \mathrm{g} / \mathrm{L}$. The groundwater distribution pattern for 1,1-dichloroethane in downgradient wells is quite similar to that of 1,1,1-trichloroethane, which suggests it may be a breakdown product of 1,1,1-trichloroethane (DOE 1993a, DOE 1994a). Like 1,1,1-trichloroethane, the concentration of 1,1-dichloroethane decreased steadily through 1996 and has either remained steady or dropped slightly since 1996.

Carbon tetrachloride was detected in both upgradient and downgradient monitoring wells at the SWL. Between 1994 and 2000, concentrations ranged from non-detect to $3.2 \mu \mathrm{g} / \mathrm{L}$ in the two southern-most downgradient wells. Occasional detections in the other six downgradient wells have ranged from 0.6 to $9.3 \mu \mathrm{g} / \mathrm{L}$ (well 699-24-34B, February 1996) without a consistent pattern, but exceeding the groundwater quality criteria of $0.3 \mu \mathrm{g} / \mathrm{L}$. Carbon tetrachloride was detected in the upgradient well 699-26-35A, and the highest concentration was $2.0 \mu \mathrm{g} / \mathrm{L}$ in August 1995.

Chloroform was detected only in downgradient wells at the SWL. Reported concentrations have been less than the groundwater quality criteria of $7 \mu \mathrm{g} / \mathrm{L}$. Maximum reported values range from $0.34 \mu \mathrm{g} / \mathrm{L}$ at well 699-24-35 to $4.6 \mu \mathrm{g} / \mathrm{L}$ (November 1996) at well 699-22-35 (Appendix B). The highest reported value is in the southernmost well. There were only occasional detections in the other wells with the highest value at $1.5 \mu \mathrm{g} / \mathrm{L}$.

Specific conductance in downgradient wells, and sometimes upgradient wells, consistently exceeds the background threshold value of $550 \mu \mathrm{S} / \mathrm{cm}$ (see Section 6.3 .3 for an explanation and discussion of background threshold values). The highest value for specific conductance was $1,557 \mu \mathrm{g} / \mathrm{L}$ in well 699-22-35. In general specific conductance increases from north to south along the line of downgradient wells. However, in many instances well 699-24-34C has the highest specific conductance values in the monitoring well network (DOE 1994a, Hodges et al. 1996). 
The increased specific conductance observed in SWL wells is principally caused by an increased carbonate or bicarbonate concentration in the groundwater (DOE 1994a). In turn, the increased carbonate concentration is the result of high carbon dioxide in the vadose zone as observed by Evans et al. (1989a) and Jacques (1993a). The elevated carbon dioxide concentrations in the vadose zone apparently result from the breakdown of sewage beneath the SWL under oxidizing conditions. The major effect of this process is an increase in the hardness of the groundwater (DOE 1994a), which is also responsible for increasing the concentration of sulfate, lowering the $\mathrm{pH}$, and raising the specific conductance. Sulfate concentration often exceeds the background threshold value $(250 \mathrm{mg} / \mathrm{L}$ standard in WAC 173-200) in wells 699-22-35 and 699-23-34B. The lowest reported $\mathrm{pH}$ value is 3.5 in well 699-24-34B. However, since 1995 reported $\mathrm{pH}$ values have not exceeded the background threshold range of 6.2 to 8.46 .

Filtered iron and zinc and chemical oxygen occasionally exceed their respective background threshold values (160, 34, and 5,000 $\mu \mathrm{g} / \mathrm{L}$ respectively) in several SWL network monitoring wells. However, these exceedances are suspected to be sampling or laboratory errors because they are not repeatable. In almost every case, these exceedances are followed by succeeding samples with results not exceeding the background threshold values. 


\subsection{Conceptual Model}

Waste disposal at the SWL has affected groundwater quality downgradient of the site. The following statements summarize the current interpretation ("Conceptual Model") of waste disposal, movement through the vadose zone, and in groundwater.

- Volatile organic compounds were disposed in the SWL in the form of catch tank liquid from the 1100 Area heavy equipment garage and bus shop. Some of this waste has reached groundwater beneath the SWL.

- The bulk of the waste disposed at the SWL was solid waste that contained no volatile organic compounds or radioactive waste.

- Significant quantities of sewage were disposed at SWL and affect groundwater quality at the SWL. Degradation of the sewage increases the concentration of carbon dioxide in the vadose zone which, in turn, increases hardness, sulfate, and specific conductance in groundwater.

- It is possible, but unlikely, that DNAPL was disposed at the SWL.

- Collected leachate from the buried waste at the SWL is known to contain arsenic, manganese, nickel, and various volatile organic compounds. These and other dangerous waste constituents remain in the landfill and may be detected in the future by groundwater monitoring network.

- Natural precipitation or water from the waste carries contaminants through the vadose zone to groundwater.

- Volatile organic compounds are present in vadose zone vapors and are the primary contaminant of concern for groundwater. Soil gas surveys suggest that the areas of highest soil gas vapors do not correspond with areas of known disposal. Contaminants may move laterally within the vadose zone via vapor transport. However, soil gas studies to date have failed to prove this. There may be other, undocumented sources of volatile organic compounds with SWL area.

- Contaminants remain in the uppermost aquifer above the low-permeability unit. Existing wells only monitor the uppermost portion of the uppermost aquifer. Additional wells downgradient are needed to discover whether waste constituents (in either the dissolved phase or DNAPLs) have reached the lower portion of the uppermost aquifer (top of the low-permeability unit).

- Regionally, groundwater flows toward the southeast; however, flow directly beneath to the SWL may be toward the east or even northeast. The hydraulic gradient in the immediate vicinity of SWL is extremely low (approximately 0.00005). 


\subsection{Groundwater Monitoring Program}

\subsection{Objectives}

The overall objectives of the Groundwater Monitoring Program at the Hanford Site are to (a) protect human health and the environment; (b) comply with governmental regulations; and (c) contribute to groundwater investigation or remediation. Specifically, the objective of the groundwater monitoring at the SWL is to determine the impact of waste disposal at the SWL on groundwater.

\subsection{Special Conditions}

There are two hydrogeological conditions at the SWL that are of special concern to the development of this groundwater monitoring plan. The first is the low-permeability unit within the Upper Ringold unit or Ringold Formation unit E. This low-permeability layer limits the thickness of the uppermost aquifer locally to about 22 meters. It is believed to limit the depth of contamination from the SWL. A groundwater monitoring plan must account for this low-permeability zone and provide assurance that groundwater contamination from SWL has not reached the top of the low-permeability unit, as well as more shallow depths of the uppermost aquifer. (See also Section 4.0, Conceptual Model.)

The second special condition is the extremely low hydraulic gradient and the difficulty to determine an accurate direction of groundwater flow in the uppermost aquifer. Water-table maps (Hartman et al. 2000, Plate 2) indicate the flow should be generally from west to east in the immediate vicinity of the SWL. However, contaminant plumes like tritium from the 200 East Area (Hartman et al. 2000, Plate 3) are moving from the northwest to the southeast. (See also Section 4.0, Conceptual Model.)

\subsection{Sampling and Analysis Plan}

\subsubsection{Monitoring Well Network}

The eight downgradient wells and two upgradient wells (Table 5.1) of the existing monitoring well network (see Figure 2.2) are designed to

- represent the quality of background groundwater that has not been affected by the SWL [WAC 173-304-490(2)(a)(i)]

- represent the quality of groundwater passing the point of compliance (downgradient wells) [WAC 173-304-490(2)(a)(ii)]

- determine whether downgradient concentrations of groundwater constituents specifically required by governmental regulations are statistically increased over background concentrations [WAC 173-304-490(2)(f)]

- determine whether concentrations of other groundwater constituents of concern (volatile organic compounds) have exceeded groundwater quality criteria or other maximum contaminant levels. 
Table 5.1. Groundwater Monitoring Wells in the Solid Waste Landfill Monitoring Network (All wells monitor the uppermost portion of the uppermost aquifer; downgradient wells listed north to south.)

\begin{tabular}{||l|c|c||}
\hline $\begin{array}{r}\text { Well Number } \\
\text { Upgradient or } \\
\text { Downgradient }\end{array}$ & Date Installed & WAC 173-160 Compliant? \\
\hline \hline $\begin{array}{l}\text { 699-26-35A } \\
\text { Upgradient }\end{array}$ & 1986 & Yes \\
\hline $\begin{array}{l}\text { 699-24-35 } \\
\text { Upgradient }\end{array}$ & 1987 & Yes \\
\hline 699-25-34C & 1987 & Yes \\
\hline 699-24-34C & 1987 & Yes \\
\hline 699-24-34B & 1987 & Yes \\
\hline 699-24-34A & 1987 & Yes \\
\hline 999-23-34A & 1987 & Yes \\
\hline $699-23-34 B$ & 1993 & Yes \\
\hline $699-22-35$ & 1993 & Yes \\
\hline $699-24-33$ & 1948 & No \\
\hline
\end{tabular}

The eight existing downgradient wells are located around the eastern and southern boundaries of the SWL (see Figure 2.2) to detect potentially contaminated groundwater in response to groundwater flowing either eastward (interpreted from water table contours: less reliable) or southeastern (interpreted from plume maps: more reliable). Monitoring Efficiency Model ("MEMO” Domenico and Robbins 1985) results demonstrate that the downgradient wells have a monitoring efficiency of approximately $95 \%$ for the flow direction of 135 degrees clockwise from due north (southeast - the most likely flow direction)(Hodges 1994).

Wells 699-24-35 and 699-26-35A (see Figure 2.2) are two existing upgradient wells in the monitoring well network and are located west and northwest of the SWL to determine background water quality. They are screened near the water table and they are compared with downgradient water quality (from 7 of the 8 downgradient wells) to determine if the SWL has adversely affected groundwater quality. All of the existing downgradient wells are also screened near the water table. (See Sections 6.2 and 6.3 for an explanation of the methods used to compare background and downgradient water quality. Well 699-26-35A is shared with the NRDWL monitoring well network.)

Well 699-24-33 is the one well of the eight downgradient wells that is not used for upgradientdowngradient water quality comparisons. It is not used because it is an older well that is not constructed to the standards of WAC 173-160. The construction is simply an 8-inch carbon steel casing drilled to 
50 meters, perforated from 35 to 50 meters below ground surface, and constructed without any surface seal, annular seal, or surface protection. Groundwater analyses from this well will continue to be used for supporting data only.

Shallow groundwater monitoring wells on the east (downgradient) side of the SWL indicate groundwater contamination with chlorinated hydrocarbons. This contamination may be due to the disposal of wash water from the bus lot. However, the evidence for this is not entirely convincing, and there is the possibility that the detected contaminants are the dissolved fraction of one or more DNAPL plumes at the bottom of the uppermost aquifer.

Two new wells are proposed to determine the geology of the lower portion of the uppermost aquifer and to sample and analyze groundwater from the uppermost aquifer immediately above the lowpermeability unit. The purpose of the new wells is to define the depth of groundwater contamination (DOE 1996a, Section 5.3) and also to look for the presence of DNAPLs. The two new wells will be drilled into the low-permeability unit for geologic and hydrologic characterization and then backfilled and completed on top of the unit. They will be located at sites immediately outside of the landfill boundary and downgradient of positions in the landfill where volatile organic compounds are most likely buried or where existing wells show the highest concentrations of volatile organic compounds (e.g., one on the east side about midway along the SWL and another at the southern end). A third deep well that could be added to the SWL network as an upgradient well would be well 699-26-35C. This existing well is being used as an upgradient/deep well for the NRDWL monitoring well network.

Installation of new wells on the Hanford Site is subject to competing site priorities and negotiations between DOE and Ecology. The location, depth, and other details of the new wells will be determined later, and this monitoring plan will be revised to include those wells after (and if) they are installed.

Appendix A contains construction details for each existing well in the groundwater monitoring network at the SWL, as well as the proposed additional well 699-26-35C (an existing well at NRDWL).

\subsubsection{Constituent List and Sampling Frequency}

WAC 173-304-490 requires that the following list of groundwater waste constituents be monitored quarterly. These waste constituents will be the basis for future groundwater monitoring at the SWL:

$\begin{array}{ll}\text { ammonium } & \text { nitrate } \\ \text { chemical oxygen demand } & \text { nitrite } \\ \text { chloride } & \mathrm{pH} \\ \text { conductivity } & \text { sulfate } \\ \text { filtered iron } & \text { temperature } \\ \text { filtered manganese } & \text { total coliform } \\ \text { filtered zinc } & \text { total organic carbon }\end{array}$


In addition, the following site-specific parameters are also proposed to be sampled quarterly. Their selection is based on waste disposal and groundwater monitoring history at the SWL and results of leachate sample analyses. The site-specific parameters include the following:

- volatile chlorinated hydrocarbons (including, but not limited to, carbon tetrachloride, 1,1-dichloroethane, 1,2-dichloroethane, tetrachloroethene, trichloroethene, 1,1,1-trichloroethane, 1,4-dioxane, and 1,4-dichlorobenzene).

- filtered arsenic

The SWL is within the major tritium, nitrate, and iodine-129 plumes from the 200 East Area. Tritium and nitrate were analytes in the previous version of the SWL groundwater monitoring plan (Hodges 1994, 1996). The success of using tritium concentrations to determine groundwater flow rate and direction at the SWL has met with limited success. In addition, tritium is not considered to be a site-specific parameter (DOE 1993a). Therefore, it will not be monitored by this groundwater monitoring plan but will be monitored by the Hanford Groundwater Monitoring Project for the Atomic Energy Act of 1954 and for the PUREX cribs (a RCRA treatment, storage, and disposal unit) (see Hartman et al. 1999). Nitrate will continue to be an analyte because it is required by WAC 173-304-490. Total organic halogens, gross alpha, and gross beta, which were included in the list of groundwater constituents analyzed at the SWL previously, are also removed from the list. Because the groundwater samples are analyzed for volatile organics, they are specifically tested for all the likely volatile organics that could have been disposed at the SWL. Therefore, there is no need to run the indicator parameter total organic halogens. Furthermore, testing for the indicator parameters gross alpha and gross beta was discontinued because there is no evidence that any radioactively-contaminated waste was disposed at the SWL, and radioactive waste has never been detected at the SWL other than at background levels or from upgradient sources (i.e., tritium).

\subsubsection{Groundwater Parameter Analysis Method Detection Limit}

Table 5.2 lists the groundwater analysis method detection limits currently in use for groundwater parameters required in Section 5.3.2, as well as the groundwater quality criteria (also called groundwater performance standards). (Note: If there is no applicable groundwater quality criteria for a particular analyte, then the groundwater performance standard is the maximum contaminant level.) The groundwater analyses methods currently used to analyze the groundwater samples are designed, for the most part, to meet the groundwater quality criteria. However, the groundwater quality criteria for a few constituents are too low, and the corresponding cost too high, to be cost effective at the present level of technology for routine analyses. These constituents include arsenic and 1,4-dioxane. For these constituents, the analysis methods selected have corresponding method detection limits as close as possible to the groundwater quality criteria to remain useful, but cost effective, for this groundwater monitoring plan.

\subsubsection{Determination of Groundwater Flow}

WAC 173-304-490(2)(h) requires that the groundwater flow direction and flow rate be determined and reported annually (see also the reporting plans in Section 6.4). 
Table 5.2. Groundwater Quality Criteria for Solid Waste Landfill Groundwater Waste Parameters and Associated Method Detection Limits

\begin{tabular}{|c|c|c|}
\hline Groundwater Constituent & $\mathrm{GWQC}^{(\mathrm{a})}(\text { or MCL) })^{(\mathrm{b})}$ & $\mathrm{MDL}^{(\mathrm{c})}\left(\mathrm{IDL}^{(\mathrm{d})}\right.$ for metals $)$ \\
\hline Temperature & -- & -- \\
\hline Specific Conductance & $700 \mu \mathrm{S} / \mathrm{cm}(\mathrm{WAC} 246-290-310)$ & $0.278 \mu \mathrm{S} / \mathrm{cm}$ \\
\hline Field $\mathrm{pH}$ & $6.5-8.5$ & 0.1 \\
\hline Total Organic Carbon & -- & $222 \mu \mathrm{g} / \mathrm{L}$ \\
\hline Chloride & $250,000 \mu \mathrm{g} / \mathrm{L}$ & $34.6 \mu \mathrm{g} / \mathrm{L}$ \\
\hline Nitrate & $(45,000 \mu \mathrm{g} / \mathrm{L})$ & $48.7 \mu \mathrm{g} / \mathrm{L}$ \\
\hline Nitrite & $(3,300 \mu \mathrm{g} / \mathrm{L})$ & $24.3 \mu \mathrm{g} / \mathrm{L}$ \\
\hline Ammonium & -- & $37 \mu \mathrm{g} / \mathrm{L}$ \\
\hline Sulfate & $250,000 \mu \mathrm{g} / \mathrm{L}$ & $108 \mu \mathrm{g} / \mathrm{L}$ \\
\hline Iron (filtered) & $300 \mu \mathrm{g} / \mathrm{L}$ & $(56.6 \mu \mathrm{g} / \mathrm{L})$ \\
\hline Zinc (filtered) & $5,000 \mu \mathrm{g} / \mathrm{L}$ & $(4.2 \mu \mathrm{g} / \mathrm{L})$ \\
\hline Manganese (filtered) & $50 \mu \mathrm{g} / \mathrm{L}$ & $(1.9 \mu \mathrm{g} / \mathrm{L})$ \\
\hline Coliform (most prob. number) & $1 / 100 \mathrm{ml}$ & -- \\
\hline Chemical Oxygen Demand & -- & $3,067 \mu \mathrm{g} / \mathrm{L}$ \\
\hline Arsenic (filtered) & $0.05 \mu \mathrm{g} / \mathrm{L}$ & $(0.9 \mu \mathrm{g} / \mathrm{L})$ \\
\hline Carbon Tetrachloride & $0.3 \mu \mathrm{g} / \mathrm{L}$ & $0.32 \mu \mathrm{g} / \mathrm{L}$ \\
\hline 1,1-Dichloroethane & $1.0 \mu \mathrm{g} / \mathrm{L}$ & $0.36 \mu \mathrm{g} / \mathrm{L}$ \\
\hline 1,2-Dichloroethane & $0.5 \mu \mathrm{g} / \mathrm{L}$ & $0.34 \mu \mathrm{g} / \mathrm{L}$ \\
\hline Tetrachloroethene & $0.8 \mu \mathrm{g} / \mathrm{L}$ & $0.15 \mu \mathrm{g} / \mathrm{L}$ \\
\hline Trichloroethene & $3.0 \mu \mathrm{g} / \mathrm{L}$ & $0.26 \mu \mathrm{g} / \mathrm{L}$ \\
\hline 1,1,1-Trichloroethane & $(200 \mu \mathrm{g} / \mathrm{L})$ & $0.35 \mu \mathrm{g} / \mathrm{L}$ \\
\hline 1,4-Dioxane & $7.0 \mu \mathrm{g} / \mathrm{L}$ & $40 \mu \mathrm{g} / \mathrm{L}$ \\
\hline 1,4-Dichlorobenzene & $(4.0 \mu \mathrm{g} / \mathrm{L})$ & $0.10 \mu \mathrm{g} / \mathrm{L}$ \\
\hline \multicolumn{3}{|c|}{$\begin{array}{l}\text { (a) Groundwater quality criteria in W AC 173-200. } \\
\text { (b) Maximum contaminant levels in } 40 \text { CFR 141, } 40 \text { CFR 143, EPA 822-R-96-001. } \\
\text { (c) Method detection level. } \\
\text { (d) Instrument detection level. }\end{array}$} \\
\hline
\end{tabular}

Depth-to-water measurements will continue to be collected from each monitoring well when each is sampled. Therefore, depth-to-water will be measured quarterly at all network wells. These depth-towater measurements will be used to construct water-table maps which, in turn, will be re-evaluated annually to determine the direction of groundwater flow beneath the SWL. 
The water table at the SWL has a very low gradient. Water-table maps constructed previously from the depth-to-water measurements (and surveyed elevation of the ground surface and casing top at each well) show that the gradient across the site is approximately 0.00005 (Weekes et al. 1987). Determining groundwater flow direction in an area the size of the SWL when the gradient in 0.00005 is very difficult. Very small errors in depth-to-water measurements or in surveyed casing elevations are significantly large compared to the low gradient. Therefore, maps showing the major plumes of tritium, nitrate, and iodine-129 will be used to corroborate flow directions based on water-table maps.

$$
\text { Using the Darcy equation, } \quad \mathrm{v}=\frac{\mathrm{K}(\mathrm{i})}{\mathrm{n}_{(\mathrm{e})}}
$$

average groundwater flow rate (v) will be calculated from known estimates of hydraulic conductivity (K), the water-table gradient (i), and effective porosity $\left(\mathrm{n}_{(\mathrm{e})}\right)$.

Another method of determining groundwater flow direction and flow rate is the use of one or more type of down-well flow meters. One type of flow meter currently being used in the 200 East Area is one using a down-hole camera with magnetometer. This type of flow meter tracks the movement of colloidal size particles by observing the particles with the camera. The flow rate and direction of the particles are recorded and used to calculate groundwater flow rate and flow direction. This type of flow meter will be used at one or more of the SWL network wells to corroborate the interpretations of flow direction and rate with more conventional methods (i.e., water-table maps, pumping tests).

\subsubsection{Sampling and Analysis Protocol}

Groundwater monitoring for the SWL is part of the Hanford Groundwater Monitoring Project. Procedures for groundwater sampling, documentation, sample preservation, shipment, and chain-ofcustody requirements are described in PNNL or subcontractor procedures manuals ${ }^{1}$ and quality requirements are provided in the quality assurance plan. ${ }^{2}$ Samples generally are collected after three casing volumes of water have been purged from the well or after field parameters $(\mathrm{pH}$, temperature, specific conductance, and turbidity) have stabilized. For routine groundwater samples, preservatives are added to the collection bottles before their use in the field. Samples to be analyzed for metals are usually filtered in the field so that results represent dissolved metals.

Procedures for field measurements are specified in the subcontractor's or manufacturer's manuals. Analytical methods are specifie d in contracts with laboratories, and most are standard methods from Test Methods for Evaluating Solid Wastes, Physical/Chemical Methods (EPA 1986a). Alternative procedures meet the guidelines of SW-846, Chapter 10. Analytical methods are described in Gillespie (1999).

\footnotetext{
${ }^{1}$ Procedure manual ES-SSPM-001, Waste Management Technical Services, Inc., Northwest Operations, Richland, Washington.

${ }^{2}$ ETD-012, Rev. 1, Quality Assurance Plan, Hanford Groundwater Monitoring Project, Pacific Northwest National Laboratory, Richland, Washington.
} 


\subsubsection{Quality Assurance and Quality Control}

The groundwater monitoring project's quality assurance/quality control (QA/QC) program is designed to assess and enhance the reliability and validity of groundwater data. The primary quantitative measures or parameters used to assess data quality are accuracy, precision, completeness, and the method detection limit. Qualitative measures include representativeness and compatibility. Goals for data representativeness for groundwater for groundwater monitoring projects are addressed qualitatively by the specification of well locations, well construction, sampling intervals, and sampling and analysis techniques in the groundwater monitoring plan for each facility. Comparability is the confidence with which one data set can be compared to another.

The QC parameters are evaluated through laboratory checks (e.g., matrix spikes, laboratory blanks), replicate sampling and analysis, analysis of blind standards and blanks, and interlaboratory comparisons. Acceptance criteria have been established for each of these parameters, ${ }^{1}$ based on guidance from the U.S. Environmental Protection Agency (EPA 1986a). When a parameter is outside the criteria, corrective actions are taken to prevent a future occurrence and affected data are flagged in the database.

\footnotetext{
${ }^{1}$ ETD-012, Rev. 1, Quality Assurance Plan, Hanford Groundwater Monitoring Project, Pacific Northwest National Laboratory, Richland, Washington.
} 


\subsection{Data Management, Evaluation, and Reporting}

This section describes how groundwater data are stored, retrieved, evaluated, and interpreted. Statistical evaluation methods and reported requirements are also described.

\subsection{Data Management}

The contract laboratories report analytical results electronically. The results are loaded into the Hanford Environmental Information System (HEIS) database. Field-measured parameters are entered manually or through electronic transfer. Paper data reports and field records are considered to be the record copies and are stored at PNNL.

The data undergo a validation/verification process according to a documented procedure (Procedure QC-5, RCRA Groundwater Data Validation and Verification Process in PNL-MA-567 Manual) cited in the project QA plan. ${ }^{1}$ QC data are evaluated against the criteria listed in the project QA plan and data flags are assigned when the data do not meet those criteria. In addition, data are screened by scientists familiar with the local hydrogeology, compared to historical trends or spatial patterns, and flagged if they are not representative. If necessary, the lab may be asked to check calculations or reanalyze the sample, or the well may be resampled.

\subsection{Interpretation}

After data are validated and verified, the data are used to interpret groundwater conditions at the site. Interpretive techniques include:

- Hydrographs: graph water levels versus time to determine decreases, increases, seasonal, or manmade fluctuations in groundwater levels.

- Water-table maps: use water-table elevations from multiple wells to construct contour maps to estimate flow directions. Groundwater flow is assumed to be perpendicular to lines of equal potential.

- Trend plots: graph concentrations of chemical or radiological constituents versus time to determine increases, decreases, and fluctuations. May be used in tandem with hydrographs and/or water-table maps to determine if concentrations relate to changes in water level or in groundwater flow directions.

\footnotetext{
${ }^{1}$ ETD-012, Rev. 1, Quality Assurance Plan, Hanford Groundwater Monitoring Project, Pacific Northwest National Laboratory, Richland, Washington.
} 
- Plume maps: map distributions of chemical or radiological constituents areally in the aquifer to determine the source and extent of contamination. Changes in plume distribution over time aid in determination of movement of plumes and direction of flow.

- Contaminant ratios: can sometimes be used to distinguish between different sources of contamination.

\subsection{Statistical Evaluation}

Statistical evaluation of data consists of the required comparisons between downgradient compliance point wells with the background data to determine whether a statistically significant change over background values has occurred for the WAC 173-304-490(2)(d) constituents [see WAC 173-304-490(2)(f)]. If there is a statistically significant increase for parameters or constituents at any monitoring well at the compliance point [WAC 173-304-490(2)(i)(ii)], then it must be determine whether the groundwater performance standard (groundwater quality criteria or maximum contaminant level; see Table 5.1) has been exceeded.

\subsubsection{Background Summary Statistics}

Summary statistics were recalculated for the WAC 173-304-490(2)(d) constituents using quarterly monitoring data collected from March 1993 to May 2000 from upgradient wells (699-24-35 and 699-26-35A). The old summary statistics were calculated from data collected from 1987 to 1993 (Hodges 1994, 1996). Results of summary statistics from the new data are presented in Table 6.1. Some of the background data are below the laboratory's specified method detection limit. Following guidance in EPA $(1989,1992)$ and Ecology (1996), the following procedures were used in handling the non-detects. In cases where the proportion of non-detects is less than $15 \%$, not detected measurements were replaced by half of their method detection limits, and the usual calculations were performed. In cases where the proportion of non-detects is between $15 \%$ to 50\%, Cohen's method (Cohen 1959, 1961) was used to estimate the mean and standard deviation (dissolved iron, manganese, and zinc). For total organic carbon, Aitchison's adjustment (Aitchison 1955) was used because the fraction of non-detects exceeds $50 \%$ and Cohen's method may not give valid results (EPA 1992, pages 27 34). For nitrite, ammonium, coliform bacteria, and chemical oxygen demand, summary statistics are not calculated because these constituents are essentially not detected.

\subsubsection{Testing the Assumption of Normality of Data}

Background water quality is statistically defined as the $95 \%$ upper tolerance interval with a $95 \%$ confidence (see Ecology 1996, page 65). The tolerance interval defines a concentration range (from background well data) that contains at least a specified proportion (coverage) of the population with a specified probability (level of confidence). There are two types of tolerance intervals: parametric and non-parametric. Parametric tolerance interval techniques are valid when the assumption that the data are drawn from a normal (or lognormal) population holds. When data is not normally (or log-normally) distributed, a non-parametric tolerance interval is used to estimate background values. 
Table 6.1. Background Summary Statistics for the Monitoring Constituent Data for the Solid Waste Landfill

\begin{tabular}{||l|l|l|l|l|l|l|l|l|l||}
\hline $\begin{array}{c}\text { Constituent } \\
(\text { Unit) }\end{array}$ & (a)
\end{tabular}

Parametric tolerance intervals are sensitive to the assumption that the data are normally distributed. The statistical tests used for evaluating whether or not the data follow a specified distribution are called goodness-of-fit tests. A recommended test is the Shapiro-Wilk test for normality of the data (Shapiro and Wilk 1965). It is considered to be one of the very best tests of normality available (Miller 1986; Mandansky 1988).

The Shapiro-Wilk test statistic (W) will tend to be large when a probability plot of the data indicates a nearly straight line (i.e., normal distribution). Only when the plotted data show significant departure from normality the test statistic will be small. Hence, if the computed value of $\mathrm{W}$ is less than the critical value 
$\mathrm{W}_{\alpha}$ for a prechosen value of $\alpha$ (e.g., $\alpha=5 \%$ ) shown in statistical table, the hypothesis of normality is rejected. The Shapiro-Wilk test of normality can be used for sample sizes up to 50. When sample size is larger than 50 (up to 98), a slight modification of the procedure called the Shapiro-Francia test (Shapiro and Francia 1972) can be used instead. Like the Shapiro-Wilk test, the Shapiro-Francia test statistic (W') will be small when the probability plot shows significant bends or curves (i.e., non-normality). Procedures are provided in EPA (1992, pages 9-12) and Shapiro (1980, pages 20-24).

Background quality data were evaluated using quarterly monitoring data collected from March 1993 to May 2000 from upgradient wells (699-24-35 and 699-26-35A). Shapiro-Francia tests were applied first on the logarithms of the original data (to test for log-normality) because sample sizes are larger than 50. If the logged data indicate non-normality, a re-test is performed on the original data to test for normality of the original concentrations. Results are provided in Table 6.2. Specific conductance, $\mathrm{pH}$, and sulfate concentration measurements from background wells are approximately log-normally distributed. Temperature, chloride, nitrate, and iron concentrations are neither lognormal nor normal. Total organic carbon, nitrite, ammonium, zinc, manganese, coliform bacteria, and chemical oxygen demand are not tested because the fractions of non-detects are much higher than $15 \%$.

\subsubsection{Re-Establish Background Levels}

The earlier background values were established for the WAC 173-304-490(2)(d) constituents based on the tolerance interval approach using monitoring data collected from upgradient wells (699-24-35 and 699-26-35A) during May 1987 to September 1993. Since then, more information has been gained and analytical laboratory has changed. It is deemed appropriate to revise the original background values (using data collected 1993 to 2000) to reflect the most current site conditions and improve estimates of background mean and standard deviation. Both the upper and lower limits of the interval (two sided) were calculated for $\mathrm{pH}$. Only the upper limits of the intervals (one sided) were calculated for other constituents.

If a lognormal (or a normal) distribution is a reasonable approximation of the background concentrations, a parametric tolerance interval (TI) of the following form is calculated.

$$
\begin{gathered}
\mathrm{TI}=\overline{\mathrm{x}}_{\mathrm{b}} \pm \mathrm{kS} \mathrm{b}_{\mathrm{b}}(\text { two-sided }), \text { or } \\
\mathrm{TI}=\overline{\mathrm{x}}_{\mathrm{b}}+\mathrm{kS}_{\mathrm{b}}(\text { one-sided })
\end{gathered}
$$

where: $\overline{\mathrm{x}}_{\mathrm{b}}=$ background mean.

$\mathrm{k}=$ a normal tolerance factor, which depends on the number of background samples (n), coverage (P\%), and confidence level (Y). A coverage of 95\% and confidence of 95\% are used. With $\mathrm{n}=60, \mathrm{P}=95 \%$, and $\mathrm{Y}=95 \%, \mathrm{k}$ is 2.022 for a one-sided normal tolerance interval (Gibbons 1991).

$\mathrm{S}_{\mathrm{b}}=$ background standard deviation.

If background concentration does not follow a lognormal or normal distribution or the proportion of non-detects is greater than $15 \%$, a nonparametric tolerance interval is constructed (Conover 1980). A 
Table 6.2. Results of Shapiro and Francia Test for Normality and Background Threshold Values for the Solid Waste Landfill

\begin{tabular}{|c|c|c|c|c|c|}
\hline $\begin{array}{l}\text { Constituent } \\
\text { (Unit) }^{(\mathrm{a})}\end{array}$ & $\begin{array}{c}\text { Test Statistic } \\
\text { W' } \\
\text { (log-value) }\end{array}$ & $\begin{array}{c}\text { Test Statistic } \\
\text { W' } \\
\text { (raw data) }\end{array}$ & $\begin{array}{c}\text { Critical Value }^{(\mathrm{c})} \\
\mathrm{W}_{\alpha}^{\prime}\end{array}$ & $\begin{array}{c}\text { Upper } \\
\text { Tolerance } \\
\text { Limit }\end{array}$ & $\begin{array}{c}\text { Background } \\
\text { Threshold Value }\end{array}$ \\
\hline Temperature & $0.953 \mathrm{~s}$ & $0.961 \mathrm{~s}$ & 0.963 & $20.7^{(\mathrm{d})}$ & 20.7 \\
\hline $\begin{array}{l}\text { Specific } \\
\text { Conductance }\end{array}$ & $0.978 \mathrm{~ns}$ & NA & 0.960 & $583^{(\mathrm{e})}$ & 583 \\
\hline Field $\mathrm{pH}$ & $0.988 \mathrm{~ns}$ & NA & 0.963 & {$[6.68,7.84]^{(\mathrm{e})}$} & {$[6.68,7.84]$} \\
\hline TOC & $\mathrm{NC}$ & $\mathrm{NC}$ & $\mathrm{NC}$ & $\begin{array}{l}842^{(\mathrm{d})} \\
1,143^{(\mathrm{f})}\end{array}$ & 1,143 \\
\hline Chloride & $0.954 \mathrm{~s}$ & $0.962 \mathrm{~s}$ & 0.963 & $7,820^{(\mathrm{d})}$ & 7,820 \\
\hline Nitrate $\left(\right.$ as $\left.\mathrm{NO}_{3}^{-}\right)$ & $0.833 \mathrm{~s}$ & $0.844 \mathrm{~s}$ & 0.963 & $29,000^{(\mathrm{d})}$ & 29,000 \\
\hline Nitrite $\left(\right.$ as $\mathrm{NO}_{2}^{-}$) & $\mathrm{NC}$ & $\mathrm{NC}$ & $\mathrm{NC}$ & $359^{(\mathrm{g})}$ & 359 \\
\hline $\begin{array}{l}\text { Ammonium (as } \\
\mathrm{NH}_{3}^{-} \text {) }\end{array}$ & $\mathrm{NC}$ & $\mathrm{NC}$ & $\mathrm{NC}$ & $\begin{array}{l}90^{(\mathrm{d})} \\
165^{(\mathrm{g})}\end{array}$ & 165 \\
\hline Sulfate & $0.983 \mathrm{~ns}$ & NA & 0.963 & $47,200^{(\mathrm{e})}$ & 47,200 \\
\hline Iron, Dissolved & $0.960 \mathrm{~s}$ & $0.802 \mathrm{~s}$ & 0.962 & $\begin{array}{l}160^{(\mathrm{d})} \\
137^{(\mathrm{g})}\end{array}$ & 160 \\
\hline Zinc, Dissolved & $\mathrm{NC}$ & $\mathrm{NC}$ & $\mathrm{NC}$ & $\begin{array}{l}34.9^{(\mathrm{d})} \\
19^{(\mathrm{g})}\end{array}$ & 34.9 \\
\hline $\begin{array}{l}\text { Manganese, } \\
\text { Dissolved }\end{array}$ & $\mathrm{NC}$ & $\mathrm{NC}$ & $\mathrm{NC}$ & $\begin{array}{l}10^{(\mathrm{d})} \\
2.3^{(\mathrm{g})}\end{array}$ & 10 \\
\hline $\begin{array}{l}\text { Coliform } \\
\text { Bacteria }\end{array}$ & $\mathrm{NC}$ & $\mathrm{NC}$ & $\mathrm{NC}$ & $3.7^{(\mathrm{h})}$ & 3.7 \\
\hline $\begin{array}{l}\text { Chemical } \\
\text { Oxygen } \\
\text { Demand }\end{array}$ & $\mathrm{NC}$ & $\mathrm{NC}$ & $\mathrm{NC}$ & $5,000^{(\mathrm{h})}$ & 5,000 \\
\hline \multicolumn{6}{|c|}{$\begin{array}{l}\text { (a) Constituents are specified in WAC 173-304-490(2)(d). Data collected from March } 1993 \text { to May } 2000 \\
\text { from upgradient wells } 699-24-35 \text { and } 699-26-35 \mathrm{~A} \text {. } \\
\text { (b) Measuring unit for temperature is }{ }^{\circ} \mathrm{C} \text {, for specific conductance is } \mu \mathrm{S} / \mathrm{cm} \text {, for coliform bacteria is } \\
\text { colonies } / 100 \mathrm{ml} \text {, all chemical constituents are in } \mu \mathrm{g} / \mathrm{L} \text {. } \\
\text { (c) Obtained from Table A-9 (in Shapiro 1980) for } \alpha=5 \% \text {. } \\
\text { (d) Maximum value reported. } \\
\text { (e) Based on log-normal distribution. } \\
\text { (f) Based on limit of quantitation using field blank data for the second quarter of FY 2000. } \\
\text { (g) Based on limit of quantitation using method detection limit (Hartman et al. 2000, Table B.20). } \\
\text { (h) Based on laboratory practical quantitation limit. }\end{array}$} \\
\hline
\end{tabular}

two-sided nonparametric tolerance interval is just the range of the observed data. An upper one-sided non-parametric tolerance limit is the largest observation. With 56 to 60 background samples for total organic carbon, nitrite, iron, manganese, zinc, coliform bacteria, and chemical oxygen demand (see Table 6.1), the upper one-sided tolerance limit defined by the largest observation contains at least $95 \%$ of the background population with $95 \%$ probability. 
In cases where all of the background values are below the contractually established detection limits or where the proportion of non-detects is more than $15 \%$, a limit of quantitation was also calculated using the fiscal year 1999 field blanks data or based on method detection limits (Hartman et al. 2000, Appendix B). Following guidance (EPA 1986b, Ecology 1996), it was decided that for cases where the calculated upper tolerance limit is below the limit of quantitation, the most recently determined limit of quantitation will be used as the background threshold value (comparison value) between data obtained from background and downgradient compliance wells. This approach uses quality control data to target the limits of quantifiable data and provides a realistic approach for background/compliance well comparisons when upgradient wells yield values that are below the detection limit. In cases where limit of quantitation is not available (e.g., coliform bacteria and chemical oxygen demand), the contractually required quantitation limits were used as the background threshold values. It should be noted that inconsistent values (i.e., outliers) were tested and removed from the background data sets in the statistical evaluations. The exclusion of extreme observation(s) from the background data sets provides smaller variability and lower comparison values. Thus, it is more conservative. The resulting background threshold values are also presented in Table 6.2.

\subsubsection{Comparisons with Groundwater Performance Standards}

Groundwater monitoring results have been, and will continue to be, compared on a quarterly basis with background levels determined in accordance to methods presented in Section 6.3.3. In addition, when there is a statistically significant increase for parameters or constituents listed in WAC 173-304490(2)(d) the owner and/or operator need to determine whether the groundwater performance standard (groundwater quality criteria or maximum contaminant level; see Table 5.2) has been exceeded, and initiate the notification process. Results of past groundwater monitoring have detected the following primary chlorinated hydrocarbons in the groundwater beneath the SWL: 1,1-dichloroethane; 1,2-dichloroethane; 1,1,1-trichloroethane; carbon tetrachloride; trichloroethene; tetrachloroethene; and 1,4-dichlorobenzene.

These contaminants will be compared with WAC 173-200 groundwater quality criteria presented in Table 6.3. If the criterion is exceeded, Ecology will determine whether corrective action program is required. In that case, this plan will be either revised or rewritten.

\subsection{Reporting}

Chemistry and water-level data are reviewed at least quarterly and are available in HEIS.

WAC 173-304-490 requires that the groundwater flow direction in the uppermost aquifer be determined at least annually. The interpreted flow direction is reported annually (usually in March) along with interpretations of groundwater quality data for the previous fiscal year in the annual report on Hanford Site groundwater monitoring (e.g., Hartman et al. 2000). 
Table 6.3. Groundwater Quality Criteria

\begin{tabular}{||l|c||}
\hline \multicolumn{1}{|c|}{ Contaminant $^{(\text {a) }}$} & Criterion $^{(\mathrm{b})}$ \\
\hline \hline 1,1,1-Trichloroethane & $0.20 \mathrm{mg} / \mathrm{L}$ \\
\hline Carbon tetrachloride & $0.3 \mu \mathrm{g} / \mathrm{L}$ \\
\hline 1,1-dichloroethane & $1.0 \mu \mathrm{g} / \mathrm{L}$ \\
\hline 1,2-dichloroethane & $0.5 \mu \mathrm{g} / \mathrm{L}$ \\
\hline 1,4-dichlorobenzene & $4 \mu \mathrm{g} / \mathrm{L}$ \\
\hline Tetrachloroethene & $0.8 \mu \mathrm{g} / \mathrm{L}$ \\
\hline Trichloroethene & $3 \mu \mathrm{g} / \mathrm{L}$ \\
\hline $\begin{array}{l}\text { (a) Based on groundwater monitoring results, the list of contaminants will be } \\
\text { revised as necessary to include any new contaminants detected in the } \\
\text { groundwater. }\end{array}$ \\
(b) Source: WAC 173-200 (Table 1). \\
\hline
\end{tabular}

WAC 173-304-490 also requires that the jurisdictional health department $\left(\right.$ Ecology $\left.^{1}\right)$ be notified in writing within seven days when there is a statistically significant increase for parameters or constituents at any of the network groundwater monitoring wells (i.e., exceedances of the background threshold values or exceedance of performance standards). The notification must indicate what parameters or constituents have shown statistically significant increases or exceedances of standards. In addition, the jurisdictional health department (Ecology) must be notif ied within 14 days of the results of any re-sampling done as a result of the increase in groundwater parameters or constituents or exceedance of performance standards. Because several groundwater parameters or constituents (e.g., specific conductance, sulfate, zinc, and chemical oxygen demand) repeatedly exceed background threshold values, notification will not occur for parameters or constituents that have historically exceeded the background threshold values or performance standards. Notification will be limited to new exceedances. If the jurisdictional health department (Ecology) requires a corrective action program as a result of parameter or constituent exceedances, a new or revised groundwater monitoring plan will be written and contain new reporting requirements.

\footnotetext{
${ }^{1}$ Responsibility for regulating the SWL was transferred from Benton-Franklin Public Health Department to Ecology.
} 


\subsection{References}

40 CFR 141, Code of Federal Regulations, Title 40, Part 141. National Primary Drinking Water Regulations.

40 CFR 143, Code of Federal Regulations, Title 40, Part 143. National Secondary Drinking Water Regulations.

Atomic Energy Act of 1954, as amended, Ch. 1073, 68 Stat. 919, 42 USC 2011 et seq.

Aitchison, J. 1955. "On the Distribution of a Positive Random Variable Having a Discrete Probability Mass at the Origin." Journal of American Statistical Association 50(272):901-908.

BHI. 1997. Conceptual Model for the SWL. BHI-01063, Bechtel Hanford, Inc., Richland, Washington.

Cohen, A. C., Jr. 1959. "Simplified Estimators for the Normal Distribution When Samples are Single Censored or Truncated." Technometrics 1:217-237.

Cohen, A. C., Jr. 1961. "Tables for Maximum Likelihood Estimates: Singly Truncated and Singly Censored Samples." Technometrics 3:535-541.

Conover, W. J. 1980. Practical Nonparametric Statistics, $2^{\text {nd }}$ ed., Wiley, New York, New York.

DOE. 1986. Compliance Ground-Water Monitoring Plan for the Hanford Site Solid Waste Landfill. U.S. Department of Energy, Richland Operations Office, Richland, Washington.

DOE. 1991a. Hanford Site Solid Waste Landfill Permit Application. DOE-RL-90-38, U.S. Department of Energy, Richland Operations Office, Richland, Washington.

DOE. 1991b. Annual Report for RCRA Groundwater Monitoring Projects at Hanford Site Facilities for 1990. DOE/RL-91-03, U.S. Department of Energy, Richland Operations, Richland, Washington.

DOE. 1992. Annual Report for RCRA Groundwater Monitoring Projects at Hanford Site Facilities for 1991. DOE/RL-92-03, U.S. Department of Energy, Richland Operations, Richland, Washington.

DOE. 1993a. Hanford Site Solid Waste Landfill Permit Application. DOE-RL-90-38, Rev. 1, U.S. Department of Energy, Richland Operations Office, Richland, Washington.

DOE. 1993b. Annual Report for RCRA Groundwater Monitoring Projects at Hanford Site Facilities for 1992. DOE/RL-93-09, Rev. 0, U.S. Department of Energy, Richland Operations Office, Richland, Washington. 
DOE. 1994a. Corrective Action Plan for the Hanford Site Solid Waste Landfill. DOE-RL-94-143, U.S. Department of Energy, Richland Operations Office, Richland, Washington.

DOE. 1994b. Annual Report for RCRA Groundwater Monitoring Projects at Hanford Site Facilities for 1993. DOE/RL-93-88, Rev. 0, U.S. Department of Energy, Richland Operations Office, Richland, Washington.

DOE. 1995. Annual Report for RCRA Groundwater Monitoring Projects at Hanford Site Facilities for 1994. DOE/RL-94-136, Rev. 0, U.S. Department of Energy, Richland Operations Office, Richland, Washington.

DOE. 1996a. Hanford Site Solid Waste Landfill Interim Closure Plan. DOE/RL-90-38, Rev. 1, U.S. Department of Energy, Richland Operations Office, Richland, Washington.

DOE. 1996b. Annual Report for RCRA Groundwater Monitoring Projects at Hanford Site Facilities for 1995. DOE/RL-96-01, Rev. 0, U.S. Department of Energy, Richland Operations Office, Richland, Washington.

Domenico, P. A., and G. A. Robbins. 1985. "A New Method of Contaminant Plume Analysis." Groundwater 23(4):476-485.

Ecology. 1996. Implementation Guidance for the Ground Water Quality Standards. Publication \#96-02, Washington State Department of Ecology Water Quality Program, Olympia, Washington.

EPA. 1986a. Test Methods for Evaluating Solid Wastes: Physical/Chemical Methods, $3^{\text {rd }}$ ed. Office of Solid Waste and Emergency Response, U.S. Environmental Protection Agency, Washington, D.C.

EPA. 1986b. Resource Conservation and Recovery Act (RCRA) Groundwater Monitoring Technical Enforcement Guidance Document (TEGD). OWSER-9950.1, U.S. Environmental Protection Agency, Washington, D.C.

EPA. 1989. Statistical Analysis of Ground-Water Monitoring Data at RCRA Facilities-Interim Final Guidance. PB89-151047, U.S. Environmental Protection Agency, Washington, D.C.

EPA. 1992. Statistical Analysis of Ground-Water Monitoring Data at RCRA Facilities: Addendum to Interim Final Guidance. U.S. Environmental Protection Agency, Washington, D.C.

EPA 822-R-96-001. 1996. Drinking Water Regulations and Health Advisories. Office of Water, U.S. Environmental Protection Agency, Washington, D.C.

ERDA-U.S. Energy Research and Development Administration. 1975. Final Environmental Statement, Waste Management Operations, Hanford Reservation, Richland, Washington. ERDA-1538, 2 vols., U.S. Energy Research and Development Administration, Richland, Washington. 
Evans, J. C., R. M. Fruland, D. W. Glover, and C. Veverka. 1989a. Final Report: Soil-Gas Survey at the Solid Waste Landfill. PNL-7147, Pacific Northwest Laboratory, Richland, Washington.

Evans, J. C., R. W. Bryce, and D. R. Sherwood. 1989b. Hanford Site Ground-Water Monitoring for January through June 1988. PNL-6886, Pacific Northwest Laboratory, Richland, Washington.

Fruland, R. M., D. J. Bates, R. A. Hagen, J. C. Evans, C. S. Cline, and R. L. Aaberg. 1989. Interim Site Characterization Report and Ground-Water Monitoring Program for the Hanford Site Solid Waste Landfill. PNL-6823, Pacific Northwest Laboratory, Richland, Washington.

Fruland, R. M., and R. E. Lundgren (eds.). 1989. RCRA Ground-Water Monitoring Projects for Hanford Facilities: Annual Progress Report for 1988. PNL-6852, Pacific Northwest Laboratory, Richland, Washington.

Gibbons, R. D. 1991. "Statistical Tolerance Limits for Ground-Water Monitoring." Ground Water 29(4):563-570.

Gillespie, B. M. 1999. Analytical Methods, Appendix C of Hanford Site Groundwater Monitoring for Fiscal Year 1998. PNNL-12086, Pacific Northwest National Laboratory, Richland, Washington.

Hall, S. H. 1988. Ground-Water Monitoring Compliance Projects for Hanford Site Facilities: Annual Progress Report for 1987. PNL-6678, Pacific Northwest Laboratory, Richland, Washington.

Hartman, M. J.(ed.). 1999. Hanford Site Groundwater Monitoring for Fiscal Year 1998. PNNL-12086, Pacific Northwest National Laboratory, Richland, Washington.

Hartman, M. J., and P. E. Dresel (eds.). 1997. Hanford Site Groundwater Monitoring for Fiscal Year 1996. PNNL-11470, Pacific Northwest National Laboratory, Richland, Washington.

Hartman, M. J., and P. E. Dresel (eds.). 1998. Hanford Site Groundwater Monitoring for Fiscal Year 1997. PNNL-11793, Pacific Northwest National Laboratory, Richland, Washington.

Hartman, M. J., L. F. Morasch, and W. D. Webber (eds.). 2000. Hanford Site Groundwater Monitoring for Fiscal Year 1999. PNNL-13116, Pacific Northwest National Laboratory, Richland, Washin gton.

Hartman, M. J., P. E. Dresel, D. R. Newcomer, and E. C. Thornton. 1999. Integrated Monitoring Plan for the Hanford Groundwater Monitoring Project. PNNL-11989, Rev. 1, Pacific Northwest National Laboratory, Richland, Washington.

Hodges, F. N. 1994. Groundwater Monitoring Plan for the Solid Waste Landfill, Hanford, Washington. WHC-SD-EN-AP-043, Westinghouse Hanford Company, Richland, Washington.

Hodges, F. N. 1996. Groundwater Monitoring Plan for the Solid Waste Landfill, Hanford, Washington. WHC-SD-EN-AP-043, Rev. 0-A, Westinghouse Hanford Company, Richland, Washington. 
Hodges, F. N. 1997. Borehole Completion Data Package for Solid Waste Landfill Facility Wells 699-2235 and 699-23-34B. PNNL-11709, Pacific Northwest National Laboratory, Ric hland, Washington.

Hodges, F. N., P. E. Dresel, and S. S. Teel. 1996. "6.12 600 Area,” in M. J. Hartman and P. E. Dresel (eds.). Hanford Site Groundwater Monitoring for Fiscal Year 1996. PNNL-11470, Pacific Northwest National Laboratory, Richland, Washington.

Jacques, I. D. 1993. Nonradioactive Dangerous Waste Landfill Soil-Gas Survey: Final Data Report. WHC-SD-EN-TI-199, Rev. 0, Westinghouse Hanford Company, Richland, Washington.

Lindberg, J. W., and M. J. Hartman. 1999. Groundwater Monitoring Plan for the Nonradioactive Dangerous Waste Landfill. PNNL-12227, Pacific Northwest National Laboratory, Richland, Washington.

Lindsey, K. A. 1991. Revised Stratigraphy for the Ringold Formation, Hanford Site, South-Central Washington. WHC-SD-EN-EE-004, Rev. 0, Westinghouse Hanford Company, Richland, Washington.

Mandansky, A. 1988. Prescriptions for Working Statisticians. Springer-Verlag, New York, New York.

Miller, R. G., Jr. 1986. Beyond ANOVA, Basics of Applied Statistics. John Wiley \& Sons, New York. New York.

Sayler, C. A. 1997. Liquid Waste Certification Plan for the Solid Waste Landfill Leachate. DYN-SWLLWCP-397, Rev. 0, DynCorp Tri-Cities Services, Inc., Richland, Washington.

Shapiro, S. S. 1980. "How to Test Normality and Other Distributional Assumptions," in the ASQC Basic References in Quality Control: Statistical Techniques, Vol. 3., Dudewicz, E. J. (ed.), American Society of Quality Control, Milwaukee, Wisconsin.

Shapiro, S. S., and R. S. Francia. 1972. "An Approximate Analysis of Variance Test for Normality." Journal of the American Statistical Association 67(337):215-216.

Shapiro, S. S., and M. B. Wilk. 1965. "An Analysis of Variance Test for Normality (complete samples)." Biometrika 52:591-611.

Smith, R. M., and W. R. Gorst (eds.). 1990. RCRA Ground-Water Monitoring Projects for Hanford Facilities: Annual Progress Report for 1989. PNL-7305, Pacific Northwest Laboratory, Richland, Washington.

WAC 173-160, Washington Administrative Code. Minimum Standards for Construction and Maintenance of Wells. Olympia, Washington.

WAC 173-200, Washington Administrative Code. Water Quality Standards for Ground Waters of the State of Washington. Olympia, Washington. 
WAC 173-304, Washington Administrative Code. Minimum Functional Standards for Solid Waste Handling. Olympia, Washington.

WAC 173-351, Washington Administrative Code. Criteria for Municipal Solid Waste Landfills. Olympia, Washington.

WAC 246-290, Washington Administrative Code. Minimum Contaminant Levels (MCLs). Olympia, Washington.

Weekes, D. C., S. P. Luttrell, and M. R. Fuchs. 1987. Interim Hydrogeologic Characterization Report and Groundwater Monitoring System for the Nonradioactive Dangerous Waste Landfill, Hanford Site, Washington. WHC-EP-0021, Westinghouse Hanford Company, Richland, Washington. 


\section{Appendix A}

\section{Leachate Monitoring Results}

(Leachate monitoring results provided by DYN) 
Table A.1. Summary of Solid Waste Landfill Leachate Analysis (first quarter 1997 through third quarter 2000)

\begin{tabular}{|c|c|c|c|c|c|c|c|c|c|c|c|c|c|c|c|c|c|}
\hline $\begin{array}{c}\text { Analytical } \\
\text { Parameters }\end{array}$ & Units & \begin{tabular}{|c} 
1st \\
Quarter \\
1997 \\
\end{tabular} & $\begin{array}{c}\text { 2nd } \\
\text { Quarter } \\
1997 \\
\end{array}$ & $\begin{array}{c}\text { 3rd } \\
\text { Quarter } \\
1997 \\
\end{array}$ & $\begin{array}{c}\text { 4th } \\
\text { Quarter } \\
1997 \\
\end{array}$ & $\begin{array}{c}\text { 1st } \\
\text { Quarter } \\
1998 \\
\end{array}$ & $\begin{array}{c}\text { 2nd } \\
\text { Quarter } \\
1998 \\
\end{array}$ & $\begin{array}{c}\text { 3rd } \\
\text { Quarter } \\
1998 \\
\end{array}$ & \begin{tabular}{|c|c} 
4th \\
Quarter \\
1998 \\
\end{tabular} & $\begin{array}{c}\text { 1st } \\
\text { Quarter } \\
1999 \\
\end{array}$ & $\begin{array}{c}\text { 2nd } \\
\text { Quarter } \\
1999 \\
\end{array}$ & $\begin{array}{c}\text { 3rd } \\
\text { Quarter } \\
1999 \\
\end{array}$ & \begin{tabular}{|c|} 
3rd \\
Quarter \\
1999 \\
Resample \\
\end{tabular} & \begin{tabular}{|c} 
4th \\
Quarter \\
1999 \\
\end{tabular} & $\begin{array}{c}\text { 1st } \\
\text { Quarter } \\
\text { 2000 }\end{array}$ & $\begin{array}{c}\text { 2nd } \\
\text { Quarter } \\
\text { 2000 } \\
\end{array}$ & \begin{tabular}{|c} 
3rd \\
Quarter \\
2000 \\
\end{tabular} \\
\hline \multicolumn{18}{|l|}{ Indicator Parameters } \\
\hline Alkalinity & $\mathrm{mg} / \mathrm{L}$ & $\begin{array}{l}\text { Not } \\
\text { required }\end{array}$ & $\begin{array}{l}\text { Not } \\
\text { required }\end{array}$ & 930 & 870 & 810 & $\begin{array}{l}\text { Not } \\
\text { required }\end{array}$ & $\begin{array}{l}\text { Not } \\
\text { required }\end{array}$ & $\begin{array}{l}\text { Not } \\
\text { required }\end{array}$ & $\begin{array}{l}\text { Not } \\
\text { required }\end{array}$ & 734 & 748 & & \begin{tabular}{|l|} 
Not \\
required
\end{tabular} & $\begin{array}{l}\text { Not } \\
\text { required }\end{array}$ & $\begin{array}{l}\text { Not } \\
\text { required }\end{array}$ & $\begin{array}{l}\text { Not } \\
\text { required }\end{array}$ \\
\hline Ammonia as $\mathrm{N}$ & $\mathrm{mg} / \mathrm{L}$ & 0.7 & 1.7 & 0.41 & 0.5 & 0.28 & 0.6 & 0.77 & 0.7 & 0.7 & 0.729 & 0.6 & & 0.7 & 0.5 & $\mid<0.909$ & 0.618 \\
\hline Bromide & $\mathrm{mg} / \mathrm{L}$ & & & & & & & & & $\begin{array}{l}\text { Not } \\
\text { required }\end{array}$ & 2 & 2 & & 3 & 2 & 2.526 & $<10.1$ \\
\hline $\begin{array}{l}\text { Chemical Oxygen } \\
\text { Demand }\end{array}$ & $\mathrm{ppm}$ & 1,053 & 410 & 210 & 180 & 200 & 237 & 222 & 203 & 211 & 203 & $\begin{array}{l}\text { Not } \\
\text { sampled }\end{array}$ & & 242 & 221 & 216 & 228 \\
\hline Chloride & $\mathrm{mg} / \mathrm{L}$ & 210 & 200 & 250 & 230 & 22 & 212 & 214 & 218 & 212.5 & 208.8 & 233 & & 238.9 & 223.5 & 188.3 & 236.2 \\
\hline Conductivity & $\begin{array}{l}\mu \mathrm{mhos} \\
/ \mathrm{cm}\end{array}$ & 2,890 & 2,400 & 2,200 & 2,000 & 2,000 & 1,987 & 2,030 & 2,130 & 1,870 & 2,100 & 2,070 & & 2,000 & 1,970 & 1,943 & 1,986 \\
\hline Fluoride & $\mathrm{mg} / \mathrm{L}$ & 27 & 6.8 & $<0.3$ & $<0.6$ & $<0.3$ & \begin{tabular}{|l|} 
Not \\
required
\end{tabular} & $\begin{array}{l}\text { Not } \\
\text { required }\end{array}$ & $\begin{array}{l}\text { Not } \\
\text { required }\end{array}$ & \begin{tabular}{|l|} 
Not \\
required
\end{tabular} & 0.05 & 0.6 & & $<0.1$ & $<0.07$ & $<0.07$ & $<0.707$ \\
\hline Nitrate as $\mathrm{N}$ & $\mathrm{mg} / \mathrm{L}$ & 0.2 & $<0.3$ & $<0.3$ & 0.07 & $<0.03$ & $\begin{array}{l}\text { Not } \\
\text { required }\end{array}$ & $\begin{array}{l}\text { Not } \\
\text { required }\end{array}$ & $\begin{array}{l}\text { Not } \\
\text { required }\end{array}$ & $\begin{array}{l}\text { Not } \\
\text { required }\end{array}$ & $<0.095$ & $<0.095$ & & $<0.19$ & $<0.4$ & $<0.4$ & $<4.04$ \\
\hline Nitrite as $\mathrm{N}$ & $\mathrm{mg} / \mathrm{L}$ & $<0.15$ & $<0.3$ & $<0.3$ & $<0.06$ & $<0.03$ & \begin{tabular}{|l|} 
Not \\
required
\end{tabular} & $\begin{array}{l}\text { Not } \\
\text { required }\end{array}$ & $\begin{array}{l}\text { Not } \\
\text { required }\end{array}$ & \begin{tabular}{|l|}
$\begin{array}{l}\text { Not } \\
\text { required }\end{array}$ \\
\end{tabular} & $<0.4$ & $<0.2$ & & $<0.4$ & $<0.2$ & $<2.02$ & $<2.02$ \\
\hline $\mathrm{pH}$ & & 7.08 & 6.97 & 7.04 & 7.02 & 7.17 & 6.95 & 7.35 & 6.96 & 7.32 & 7.17 & 6.92 & & 7.6 & 6.14 & 7.43 & 7.39 \\
\hline Phosphate & $\mathrm{mg} / \mathrm{L}$ & & & & & & & & & \begin{tabular}{|l|} 
Not \\
required
\end{tabular} & $<0.29$ & $<0.295$ & & $<0.59$ & $<0.6$ & $<0.6$ & $<6.06$ \\
\hline Sulfate & $\mathrm{mg} / \mathrm{L}$ & $<1.5$ & $<3.0$ & $<0.3$ & 0.4 & 1.3 & $\begin{array}{l}\text { Not } \\
\text { required }\end{array}$ & $\begin{array}{l}\text { Not } \\
\text { required }\end{array}$ & $\begin{array}{l}\text { Not } \\
\text { required }\end{array}$ & \begin{tabular}{|l|} 
Not \\
required
\end{tabular} & 6.345 & 6.85 & & 8 & 8 & 7.664 & $<20.2$ \\
\hline Total Dissolved Solids & $\mathrm{mg} / \mathrm{L}$ & $\begin{array}{l}\text { Not } \\
\text { required }\end{array}$ & \begin{tabular}{|l|}
$\begin{array}{l}\text { Not } \\
\text { required }\end{array}$ \\
\end{tabular} & 1,300 & 1,400 & 1,400 & \begin{tabular}{|l|} 
Not \\
required
\end{tabular} & $\begin{array}{l}\text { Not } \\
\text { required }\end{array}$ & $\begin{array}{l}\text { Not } \\
\text { required }\end{array}$ & \begin{tabular}{|l|}
$\begin{array}{l}\text { Not } \\
\text { required }\end{array}$ \\
\end{tabular} & 1190 & 1312 & & 1300 & 1,288 & 1,297 & 1,361 \\
\hline Total Organic Carbon & $\mathrm{mg} / \mathrm{L}$ & 330 & 140 & 68 & 68 & 65 & 90.2 & 56 & 65.4 & 74.1 & 63.5 & 69.1 & & 59.55 & 61.6 & 58.05 & 61.45 \\
\hline Total Organic Halides & $\mu \mathrm{g} / \mathrm{L}$ & 330 & 590 & $<0.5$ & 610 & 710 & \begin{tabular}{|l|} 
Not \\
required
\end{tabular} & \begin{tabular}{|l|}
$\begin{array}{l}\text { Not } \\
\text { required }\end{array}$ \\
\end{tabular} & $\begin{array}{l}\text { Not } \\
\text { required }\end{array}$ & \begin{tabular}{|l|} 
Not \\
required
\end{tabular} & 83.9 & 1.06 & & 724 & 586 & 945 & 708 \\
\hline \multicolumn{18}{|l|}{ Inorganics } \\
\hline Aluminum & $\mu \mathrm{g} / \mathrm{L}$ & $\begin{array}{l}\text { Not } \\
\text { required }\end{array}$ & $\begin{array}{l}\text { Not } \\
\text { required }\end{array}$ & \begin{tabular}{|l} 
Not \\
required
\end{tabular} & $<200$ & \begin{tabular}{|l} 
Not \\
required
\end{tabular} & $\begin{array}{l}\text { Not } \\
\text { required }\end{array}$ & $\begin{array}{l}\text { Not } \\
\text { required }\end{array}$ & \begin{tabular}{|l} 
Not \\
required
\end{tabular} & \begin{tabular}{|l} 
Not \\
required
\end{tabular} & 29.2 & 95.9 & 139 & 27.2 & 21.5 & 22.1 & 31.7 \\
\hline Antimony & $\mu \mathrm{g} / \mathrm{L}$ & $\begin{array}{l}\text { Not } \\
\text { required }\end{array}$ & \begin{tabular}{|l|l} 
Not \\
required
\end{tabular} & $<1$ & $<1$ & $<10$ & \begin{tabular}{|l} 
Not \\
required
\end{tabular} & $\begin{array}{l}\text { Not } \\
\text { required }\end{array}$ & $\begin{array}{l}\text { Not } \\
\text { required }\end{array}$ & $\begin{array}{l}\text { Not } \\
\text { required }\end{array}$ & 27.3 & 236 & 14.6 & 0.812 & 0.28 & $<0.25$ & 0.263 \\
\hline Arsenic & $\mu \mathrm{g} / \mathrm{L}$ & 27 & 19 & 22 & 23 & 28 & 8.5 & 15 & 25.9 & 38.5 & 21.2 & 39.9 & 66 & 19.2 & 17.5 & 13 & 15.6 \\
\hline Barium & $\mu \mathrm{g} / \mathrm{L}$ & 720 & 620 & 580 & 530 & 500 & 469 & 404 & 451 & 489 & 456 & 475 & 495 & 458 & 444 & 384 & 447 \\
\hline
\end{tabular}




\begin{tabular}{|c|c|c|c|c|c|c|c|c|c|c|c|c|c|c|c|c|c|}
\hline $\begin{array}{c}\text { Analytical } \\
\text { Parameters }\end{array}$ & Units & \begin{tabular}{|c|} 
1st \\
Quarter \\
1997 \\
\end{tabular} & \begin{tabular}{|c|c} 
2nd \\
Quarter \\
1997 \\
\end{tabular} & $\begin{array}{c}\text { 3rd } \\
\text { Quarter } \\
1997 \\
\end{array}$ & $\begin{array}{c}\text { 4th } \\
\text { Quarter } \\
1997 \\
\end{array}$ & $\begin{array}{c}\text { 1st } \\
\text { Quarter } \\
1998 \\
\end{array}$ & $\begin{array}{c}\text { 2nd } \\
\text { Quarter } \\
1998 \\
\end{array}$ & $\begin{array}{c}\text { 3rd } \\
\text { Quarter } \\
1998 \\
\end{array}$ & $\begin{array}{c}\text { 4th } \\
\text { Quarter } \\
1998 \\
\end{array}$ & $\begin{array}{c}\text { 1st } \\
\text { Quarter } \\
1999 \\
\end{array}$ & $\begin{array}{c}\text { 2nd } \\
\text { Quarter } \\
1999 \\
\end{array}$ & $\begin{array}{c}\text { 3rd } \\
\text { Quarter } \\
1999 \\
\end{array}$ & \begin{tabular}{|c|} 
3rd \\
Quarter \\
1999 \\
Resample \\
\end{tabular} & $\begin{array}{c}\text { 4th } \\
\text { Quarter } \\
1999\end{array}$ & $\begin{array}{c}\text { 1st } \\
\text { Quarter } \\
2000 \\
\end{array}$ & $\begin{array}{c}\text { 2nd } \\
\text { Quarter } \\
2000 \\
\end{array}$ & $\begin{array}{c}\text { 3rd } \\
\text { Quarter } \\
2000 \\
\end{array}$ \\
\hline Beryllium & $\mu \mathrm{g} / \mathrm{L}$ & $\begin{array}{l}\begin{array}{l}\text { Not } \\
\text { required }\end{array} \\
\end{array}$ & $\begin{array}{l}\text { Not } \\
\text { required }\end{array}$ & $<3$ & $<3$ & $<5$ & $\begin{array}{l}\begin{array}{l}\text { Not } \\
\text { required }\end{array} \\
\end{array}$ & \begin{tabular}{|l}
$\begin{array}{l}\text { Not } \\
\text { required }\end{array}$ \\
\end{tabular} & \begin{tabular}{|l}
$\begin{array}{l}\text { Not } \\
\text { required }\end{array}$ \\
\end{tabular} & \begin{tabular}{|l|l|}
$\begin{array}{l}\text { Not } \\
\text { required }\end{array}$ \\
\end{tabular} & 2 & 0.611 & 0.865 & $<0.25$ & $<0.125$ & $\mid<0.125$ & $<0.125$ \\
\hline Cadmium & $\mu \mathrm{g} / \mathrm{L}$ & \begin{tabular}{|l|} 
Not \\
required
\end{tabular} & $\begin{array}{l}\text { Not } \\
\text { required }\end{array}$ & $<0.5$ & $<0.5$ & $<5$ & \begin{tabular}{|l} 
Not \\
required
\end{tabular} & 1.1 & \begin{tabular}{|l} 
Not \\
required
\end{tabular} & \begin{tabular}{|l|}
$\begin{array}{l}\text { Not } \\
\text { required }\end{array}$ \\
\end{tabular} & 2.1 & $<0.55$ & 0.57 & $<0.5$ & 0.45 & 0.29 & $<0.25$ \\
\hline Calcium & $\mathrm{mg} / \mathrm{L}$ & \begin{tabular}{|l|}
$\begin{array}{l}\text { Not } \\
\text { required }\end{array}$ \\
\end{tabular} & \begin{tabular}{|l}
$\begin{array}{l}\text { Not } \\
\text { required }\end{array}$ \\
\end{tabular} & 240 & 220 & 220 & \begin{tabular}{|l|l|}
$\begin{array}{l}\text { Not } \\
\text { required }\end{array}$ \\
\end{tabular} & \begin{tabular}{|l|}
$\begin{array}{l}\text { Not } \\
\text { required }\end{array}$ \\
\end{tabular} & \begin{tabular}{|l|l}
$\begin{array}{l}\text { Not } \\
\text { required }\end{array}$ \\
\end{tabular} & \begin{tabular}{|l|}
$\begin{array}{l}\text { Not } \\
\text { required }\end{array}$ \\
\end{tabular} & \begin{tabular}{|l|l|}
$\begin{array}{l}\text { Not } \\
\text { required }\end{array}$ \\
\end{tabular} & \begin{tabular}{|l|l|}
$\begin{array}{l}\text { Not } \\
\text { required }\end{array}$ \\
\end{tabular} & & \begin{tabular}{|l|l}
$\begin{array}{l}\text { Not } \\
\text { required }\end{array}$ \\
\end{tabular} & \begin{tabular}{|l|l|}
$\begin{array}{l}\text { Not } \\
\text { required }\end{array}$ \\
\end{tabular} & \begin{tabular}{|l|l|}
$\begin{array}{l}\text { Not } \\
\text { required }\end{array}$ \\
\end{tabular} & \begin{tabular}{|l|l}
$\begin{array}{l}\text { Not } \\
\text { required }\end{array}$ \\
\end{tabular} \\
\hline Chromium & $\mu \mathrm{g} / \mathrm{L}$ & $<10$ & $<10$ & $<10$ & $<10$ & $<10$ & $<7$ & 2.9 & 3.7 & 6.6 & $<6$ & $<3.85$ & $<3.85$ & $<3$ & $<1.5$ & $<1.5$ & 1.7 \\
\hline Cobalt & $\mu \mathrm{g} / \mathrm{L}$ & 29 & $<50$ & $<50$ & $<50$ & 12 & $<13$ & $\begin{array}{l}\text { Not } \\
\text { required }\end{array}$ & \begin{tabular}{|l} 
Not \\
required
\end{tabular} & \begin{tabular}{|l} 
Not \\
required
\end{tabular} & 5.3 & 4.14 & 10.4 & 4.55 & 4.01 & 4.2 & 4.25 \\
\hline Copper & $\mu \mathrm{g} / \mathrm{L}$ & $\begin{array}{l}\text { Not } \\
\text { required }\end{array}$ & $\begin{array}{l}\text { Not } \\
\text { required }\end{array}$ & $<20$ & $<20$ & 19 & $\begin{array}{l}\text { Not } \\
\text { required }\end{array}$ & $\begin{array}{l}\text { Not } \\
\text { required }\end{array}$ & $\begin{array}{l}\text { Not } \\
\text { required }\end{array}$ & $\begin{array}{l}\text { Not } \\
\text { required }\end{array}$ & 14.5 & 15.5 & 2.5 & 7.97 & 4.05 & 2.78 & 4.01 \\
\hline Iron & $\mu \mathrm{g} / \mathrm{L}$ & 39,000 & 20,000 & 19,000 & 18,000 & 19,000 & 17,600 & $\begin{array}{l}\text { Not } \\
\text { required }\end{array}$ & $\begin{array}{l}\text { Not } \\
\text { required }\end{array}$ & $\begin{array}{l}\text { Not } \\
\text { required }\end{array}$ & $\begin{array}{l}\text { Not } \\
\text { required }\end{array}$ & $\begin{array}{l}\text { Not } \\
\text { required }\end{array}$ & & $\begin{array}{l}\text { Not } \\
\text { required }\end{array}$ & $\begin{array}{l}\text { Not } \\
\text { required }\end{array}$ & $\begin{array}{l}\text { Not } \\
\text { required }\end{array}$ & $\begin{array}{l}\text { Not } \\
\text { required }\end{array}$ \\
\hline Lead & $\mu \mathrm{g} / \mathrm{L}$ & $\begin{array}{l}\text { Not } \\
\text { required }\end{array}$ & $\begin{array}{l}\text { Not } \\
\text { required }\end{array}$ & 0.52 & 7.3 & $<5$ & $\begin{array}{l}\text { Not } \\
\text { required }\end{array}$ & $<0.2$ & $\begin{array}{l}\text { Not } \\
\text { required }\end{array}$ & $\begin{array}{l}\text { Not } \\
\text { required }\end{array}$ & 5.18 & 4.94 & 2.16 & $<3$ & 3.59 & $<1.5$ & $<1.5$ \\
\hline Magnesium & $\mu \mathrm{g} / \mathrm{L}$ & \begin{tabular}{|l|}
$\begin{array}{l}\text { Not } \\
\text { required }\end{array}$ \\
\end{tabular} & \begin{tabular}{|l|}
$\begin{array}{l}\text { Not } \\
\text { required }\end{array}$ \\
\end{tabular} & 130,000 & 110,000 & \begin{tabular}{|l|}
$\begin{array}{l}\text { Not } \\
\text { required }\end{array}$ \\
\end{tabular} & \begin{tabular}{|l} 
Not \\
required
\end{tabular} & \begin{tabular}{|l|}
$\begin{array}{l}\text { Not } \\
\text { required }\end{array}$ \\
\end{tabular} & \begin{tabular}{|l|}
$\begin{array}{l}\text { Not } \\
\text { required }\end{array}$ \\
\end{tabular} & \begin{tabular}{|l|} 
Not \\
required
\end{tabular} & \begin{tabular}{|l|}
$\begin{array}{l}\text { Not } \\
\text { required }\end{array}$ \\
\end{tabular} & \begin{tabular}{|l} 
Not \\
required
\end{tabular} & & \begin{tabular}{|l} 
Not \\
required
\end{tabular} & \begin{tabular}{|l|} 
Not \\
required
\end{tabular} & \begin{tabular}{|l|}
$\begin{array}{l}\text { Not } \\
\text { required }\end{array}$ \\
\end{tabular} & \begin{tabular}{|l|}
$\begin{array}{l}\text { Not } \\
\text { required }\end{array}$ \\
\end{tabular} \\
\hline Manganese & $\mu \mathrm{g} / \mathrm{L}$ & 1,400 & 930 & 1,400 & 1,500 & 1,600 & 1,650 & \begin{tabular}{|l} 
Not \\
required
\end{tabular} & \begin{tabular}{|l|}
$\begin{array}{l}\text { Not } \\
\text { required }\end{array}$ \\
\end{tabular} & \begin{tabular}{|l|}
$\begin{array}{l}\text { Not } \\
\text { required }\end{array}$ \\
\end{tabular} & 2,500 & 2,360 & 2,700 & 2,480 & 2,480 & 2,310 & 2,850 \\
\hline Mercury & $\mu \mathrm{g} / \mathrm{L}$ & $<0.2$ & $<0.2$ & 0.41 & $<0.2$ & 10 & $<0.2$ & $<0.2$ & $<0.2$ & 2.27 & $<2$ & 4.14 & $<4.4$ & $<0.25$ & $<0.125$ & 0.255 & $<0.125$ \\
\hline Molybdenum & $\mu \mathrm{g} / \mathrm{L}$ & & & & & & & & & \begin{tabular}{|l|} 
Not \\
required
\end{tabular} & 50 & $<132$ & $<132$ & 6.79 & QC fail & 7.22 & 6.17 \\
\hline Nickel & $\mu \mathrm{g} / \mathrm{L}$ & 200 & 220 & 240 & 220 & 210 & 217 & $\begin{array}{l}\text { Not } \\
\text { required }\end{array}$ & $\begin{array}{l}\text { Not } \\
\text { required }\end{array}$ & \begin{tabular}{|l|} 
Not \\
required
\end{tabular} & 218 & 215 & 213 & 208 & 179 & 191 & 233 \\
\hline Potassium & $\mu \mathrm{g} / \mathrm{L}$ & \begin{tabular}{|l} 
Not \\
required
\end{tabular} & $\begin{array}{l}\text { Not } \\
\text { required }\end{array}$ & 15 & 13 & 14 & \begin{tabular}{|l} 
Not \\
required
\end{tabular} & $\begin{array}{l}\text { Not } \\
\text { required }\end{array}$ & \begin{tabular}{|l} 
Not \\
required
\end{tabular} & $\begin{array}{l}\text { Not } \\
\text { required }\end{array}$ & \begin{tabular}{|l} 
Not \\
required
\end{tabular} & $\begin{array}{l}\text { Not } \\
\text { required }\end{array}$ & & $\begin{array}{l}\text { Not } \\
\text { required }\end{array}$ & \begin{tabular}{|l|} 
Not \\
required
\end{tabular} & $\begin{array}{l}\text { Not } \\
\text { required }\end{array}$ & \begin{tabular}{|l} 
Not \\
required
\end{tabular} \\
\hline Selenium & $\mu \mathrm{g} / \mathrm{L}$ & $\begin{array}{l}\text { Not } \\
\text { required }\end{array}$ & $\begin{array}{l}\text { Not } \\
\text { required }\end{array}$ & $<2$ & $<2$ & $<20$ & $\begin{array}{l}\text { Not } \\
\text { required }\end{array}$ & 4.6 & $\begin{array}{l}\text { Not } \\
\text { required }\end{array}$ & $\begin{array}{l}\text { Not } \\
\text { required }\end{array}$ & $\mid<12$ & $<55$ & $\mid<55$ & 3.65 & 2.79 & 2.48 & 2.5 \\
\hline Silver & $\mu \mathrm{g} / \mathrm{L}$ & $\begin{array}{l}\text { Not } \\
\text { required }\end{array}$ & $\begin{array}{l}\text { Not } \\
\text { required }\end{array}$ & $<20$ & $<0.5$ & $<5$ & $\begin{array}{l}\text { Not } \\
\text { required }\end{array}$ & $<0.2$ & $\begin{array}{l}\text { Not } \\
\text { required }\end{array}$ & $\begin{array}{l}\text { Not } \\
\text { required }\end{array}$ & $\mid<2$ & 6.06 & $\mid<1.1$ & $<0.5$ & $<0.25$ & $<0.25$ & $<0.25$ \\
\hline Sodium & $\mu \mathrm{g} / \mathrm{L}$ & $\begin{array}{l}\text { Not } \\
\text { required }\end{array}$ & $\begin{array}{l}\text { Not } \\
\text { required }\end{array}$ & 64 & 62 & 61 & $\begin{array}{l}\text { Not } \\
\text { required }\end{array}$ & $\begin{array}{l}\text { Not } \\
\text { required }\end{array}$ & $\begin{array}{l}\text { Not } \\
\text { required }\end{array}$ & $\begin{array}{l}\text { Not } \\
\text { required }\end{array}$ & $\begin{array}{l}\text { Not } \\
\text { required }\end{array}$ & $\begin{array}{l}\text { Not } \\
\text { required }\end{array}$ & & $\begin{array}{l}\text { Not } \\
\text { required }\end{array}$ & $\begin{array}{l}\text { Not } \\
\text { required }\end{array}$ & $\begin{array}{l}\text { Not } \\
\text { required }\end{array}$ & $\begin{array}{l}\text { Not } \\
\text { required }\end{array}$ \\
\hline Thallium & $\mu \mathrm{g} / \mathrm{L}$ & $\begin{array}{l}\text { Not } \\
\text { required }\end{array}$ & $\begin{array}{l}\text { Not } \\
\text { required }\end{array}$ & $<1,500$ & $<0.5$ & $<5$ & $\begin{array}{l}\text { Not } \\
\text { required }\end{array}$ & $\begin{array}{l}\text { Not } \\
\text { required }\end{array}$ & $\begin{array}{l}\text { Not } \\
\text { required }\end{array}$ & $\begin{array}{l}\text { Not } \\
\text { required }\end{array}$ & $\mid<1$ & 0.715 & 0.85 & $<0.25$ & $\mid<0.125$ & $\mid<0.125$ & $<0.125$ \\
\hline Thorium & $\mu \mathrm{g} / \mathrm{L}$ & & & & & & & & & \begin{tabular}{|l|}
$\begin{array}{l}\text { Not } \\
\text { required }\end{array}$ \\
\end{tabular} & $<1$ & $<16.5$ & $<16.5$ & $<0.25$ & 0.131 & $<0.125$ & $<0.125$ \\
\hline Uranium & $\mu \mathrm{g} / \mathrm{L}$ & & & & & & & & & \begin{tabular}{|l|} 
Not \\
required
\end{tabular} & 7 & $<1.1$ & 1.13 & $<0.25$ & 0.163 & 0.206 & $<0.125$ \\
\hline Vanadium & $\mu \mathrm{g} / \mathrm{L}$ & \begin{tabular}{|l|} 
Not \\
required
\end{tabular} & $\begin{array}{l}\text { Not } \\
\text { required }\end{array}$ & $<50$ & $<50$ & \begin{tabular}{|l|} 
Not \\
required
\end{tabular} & \begin{tabular}{|l|} 
Not \\
required
\end{tabular} & \begin{tabular}{|l|} 
Not \\
required
\end{tabular} & \begin{tabular}{|l|} 
Not \\
required
\end{tabular} & \begin{tabular}{|l|} 
Not \\
required
\end{tabular} & 9.13 & $<1.65$ & 1.8 & 3.01 & 2.54 & 2.49 & 2.98 \\
\hline
\end{tabular}




\begin{tabular}{|c|c|c|c|c|c|c|c|c|c|c|c|c|c|c|c|c|c|}
\hline $\begin{array}{l}\text { Analytical } \\
\text { Parameters }\end{array}$ & Units & $\begin{array}{c}\text { 1st } \\
\text { Quarter } \\
1997\end{array}$ & $\begin{array}{c}\text { 2nd } \\
\text { Quarter } \\
1997\end{array}$ & $\begin{array}{c}\text { 3rd } \\
\text { Quarter } \\
1997\end{array}$ & $\begin{array}{c}\text { 4th } \\
\text { Quarter } \\
1997\end{array}$ & $\begin{array}{c}\text { 1st } \\
\text { Quarter } \\
1998\end{array}$ & $\begin{array}{c}\text { 2nd } \\
\text { Quarter } \\
1998\end{array}$ & $\begin{array}{c}\text { 3rd } \\
\text { Quarter } \\
1998\end{array}$ & $\begin{array}{c}\text { 4th } \\
\text { Quarter } \\
1998\end{array}$ & $\begin{array}{c}\text { 1st } \\
\text { Quarter } \\
1999\end{array}$ & $\begin{array}{c}\text { 2nd } \\
\text { Quarter } \\
1999\end{array}$ & $\begin{array}{c}\text { 3rd } \\
\text { Quarter } \\
1999\end{array}$ & \begin{tabular}{|c|} 
3rd \\
Quarter \\
1999 \\
Resample
\end{tabular} & $\begin{array}{c}\text { 4th } \\
\text { Quarter } \\
1999\end{array}$ & $\begin{array}{c}\text { 1st } \\
\text { Quarter } \\
2000\end{array}$ & $\begin{array}{c}\text { 2nd } \\
\text { Quarter } \\
2000\end{array}$ & $\begin{array}{c}\text { 3rd } \\
\text { Quarter } \\
2000\end{array}$ \\
\hline Zinc & $\mu \mathrm{g} / \mathrm{L}$ & $\begin{array}{l}\begin{array}{l}\text { Not } \\
\text { required }\end{array} \\
\end{array}$ & $\begin{array}{l}\text { Not } \\
\text { required }\end{array}$ & 1,300 & 2,800 & 41 & $\begin{array}{l}\begin{array}{l}\text { Not } \\
\text { required }\end{array} \\
\end{array}$ & $\begin{array}{l}\begin{array}{l}\text { Not } \\
\text { required }\end{array} \\
\end{array}$ & $\begin{array}{l}\begin{array}{l}\text { Not } \\
\text { required }\end{array} \\
\end{array}$ & $\begin{array}{l}\begin{array}{l}\text { Not } \\
\text { required }\end{array} \\
\end{array}$ & 1,880 & 646 & 15 & 1,490 & 649 & 448 & 584 \\
\hline \multicolumn{18}{|l|}{ Organics } \\
\hline \begin{tabular}{|l|}
$1,1,1,2-$ \\
Tetrachloroethane \\
\end{tabular} & $\mu \mathrm{g} / \mathrm{L}$ & \begin{tabular}{|l|}
$\begin{array}{l}\text { Not } \\
\text { required }\end{array}$ \\
\end{tabular} & $<0.4$ & $<0.4$ & Not required & $<0.4$ & \begin{tabular}{|l|}
$\begin{array}{l}\text { Not } \\
\text { required }\end{array}$ \\
\end{tabular} & \begin{tabular}{|l|}
$\begin{array}{l}\text { Not } \\
\text { required }\end{array}$ \\
\end{tabular} & \begin{tabular}{|l|}
$\begin{array}{l}\text { Not } \\
\text { required }\end{array}$ \\
\end{tabular} & \begin{tabular}{|l|}
$\begin{array}{l}\text { Not } \\
\text { required }\end{array}$ \\
\end{tabular} & \begin{tabular}{|l|}
$\begin{array}{l}\text { Not } \\
\text { required }\end{array}$ \\
\end{tabular} & \begin{tabular}{|l|}
$\begin{array}{l}\text { Not } \\
\text { required }\end{array}$ \\
\end{tabular} & & \begin{tabular}{|l|}
$\begin{array}{l}\text { Not } \\
\text { required }\end{array}$ \\
\end{tabular} & \begin{tabular}{|l|}
$\begin{array}{l}\text { Not } \\
\text { required }\end{array}$ \\
\end{tabular} & \begin{tabular}{|l|}
$\begin{array}{l}\text { Not } \\
\text { required }\end{array}$ \\
\end{tabular} & \begin{tabular}{|l|}
$\begin{array}{l}\text { Not } \\
\text { required }\end{array}$ \\
\end{tabular} \\
\hline 1,1,1-Trichloroethane & $\mu \mathrm{g} / \mathrm{L}$ & $<0.4$ & $<0.4$ & $<0.4$ & $<0.4$ & $<0.4$ & $<0.60$ & $<0.6$ & 0.6 & $<300$ & $<0.6$ & $<0.6$ & & $<0.6$ & $<0.6$ & $<0.6$ & $<0.6$ \\
\hline \begin{tabular}{|l|}
$1,1,2,2-$ \\
Tetrachloroethane
\end{tabular} & $\mu \mathrm{g} / \mathrm{L}$ & $<0.4$ & $<0.4$ & $<0.4$ & Not required & $<0.4$ & $\begin{array}{l}\text { Not } \\
\text { required }\end{array}$ & $\begin{array}{l}\text { Not } \\
\text { required }\end{array}$ & $\begin{array}{l}\text { Not } \\
\text { required }\end{array}$ & $\begin{array}{l}\text { Not } \\
\text { required }\end{array}$ & $\begin{array}{l}\text { Not } \\
\text { required }\end{array}$ & $\begin{array}{l}\text { Not } \\
\text { required }\end{array}$ & & $\begin{array}{l}\text { Not } \\
\text { required }\end{array}$ & $\begin{array}{l}\text { Not } \\
\text { required }\end{array}$ & $\begin{array}{l}\text { Not } \\
\text { required }\end{array}$ & $<0.6$ \\
\hline 1,1,2-Trichloroethane & $\mu \mathrm{g} / \mathrm{L}$ & $<0.4$ & $<0.4$ & $<0.4$ & Not required & $<0.4$ & $<0.60$ & $<0.6$ & \begin{tabular}{|l|}
$\begin{array}{l}\text { Not } \\
\text { required }\end{array}$ \\
\end{tabular} & \begin{tabular}{|l|}
$\begin{array}{l}\text { Not } \\
\text { required }\end{array}$ \\
\end{tabular} & $<0.6$ & $<0.6$ & & $<0.6$ & $<0.6$ & $<0.6$ & $<0.6$ \\
\hline 1,1-Dichloroethane & $\mu \mathrm{g} / \mathrm{L}$ & $<0.4$ & $<0.4$ & 0.44 & 1.4 & 0.8 & $<0.30$ & $<0.3$ & 1 & $<200$ & $<0.6$ & $<0.3$ & & $<0.3$ & $<0.3$ & $<0.3$ & $<0.3$ \\
\hline 1,1-Dichloroethene & $\mu \mathrm{g} / \mathrm{L}$ & $<0.4$ & $<0.4$ & $<0.4$ & Not required & $<0.4$ & \begin{tabular}{|l|}
$\begin{array}{l}\text { Not } \\
\text { required }\end{array}$ \\
\end{tabular} & $<0.4$ & \begin{tabular}{|l} 
Not \\
required
\end{tabular} & \begin{tabular}{|l|} 
Not \\
required
\end{tabular} & \begin{tabular}{|l|} 
Not \\
required
\end{tabular} & $<0.4$ & & $<0.4$ & $<0.4$ & $<0.4$ & $<0.4$ \\
\hline $\begin{array}{l}1,2,3- \\
\text { Trichloropropane }\end{array}$ & $\mu \mathrm{g} / \mathrm{L}$ & $\begin{array}{l}\text { Not } \\
\text { required }\end{array}$ & $<0.4$ & $<0.4$ & Not required & $<0.4$ & $\begin{array}{l}\text { Not } \\
\text { required }\end{array}$ & $\begin{array}{l}\text { Not } \\
\text { required }\end{array}$ & $\begin{array}{l}\text { Not } \\
\text { required }\end{array}$ & $\begin{array}{l}\text { Not } \\
\text { required }\end{array}$ & $\begin{array}{l}\text { Not } \\
\text { required }\end{array}$ & $\begin{array}{l}\text { Not } \\
\text { required }\end{array}$ & & \begin{tabular}{|l|} 
Not \\
required
\end{tabular} & $\begin{array}{l}\text { Not } \\
\text { required }\end{array}$ & $\begin{array}{l}\text { Not } \\
\text { required }\end{array}$ & $\begin{array}{l}\text { Not } \\
\text { required }\end{array}$ \\
\hline \begin{tabular}{|l|}
$1,2,4-$ \\
Trichlorobenzene
\end{tabular} & $\mu \mathrm{g} / \mathrm{L}$ & & & & & & & & & & & & & $\mid<64$ & $<5.4$ & $<5.4$ & $<5.4$ \\
\hline $\begin{array}{l}\text { 1,2-Dibromo-3- } \\
\text { chloropropane }\end{array}$ & $\mu \mathrm{g} / \mathrm{L}$ & $\begin{array}{l}\text { Not } \\
\text { required }\end{array}$ & $<0.4$ & $\begin{array}{l}\text { Not } \\
\text { required }\end{array}$ & Not required & $<0.4$ & $\begin{array}{l}\text { Not } \\
\text { required }\end{array}$ & $\begin{array}{l}\text { Not } \\
\text { required }\end{array}$ & $\begin{array}{l}\text { Not } \\
\text { required }\end{array}$ & \begin{tabular}{|l|} 
Not \\
required
\end{tabular} & $\begin{array}{l}\text { Not } \\
\text { required }\end{array}$ & $\begin{array}{l}\text { Not } \\
\text { required }\end{array}$ & & \begin{tabular}{|l|} 
Not \\
required
\end{tabular} & $\begin{array}{l}\text { Not } \\
\text { required }\end{array}$ & $\begin{array}{l}\text { Not } \\
\text { required }\end{array}$ & $\begin{array}{l}\text { Not } \\
\text { required }\end{array}$ \\
\hline 1,2-Dibromoethane & $\mu \mathrm{g} / \mathrm{L}$ & $\begin{array}{l}\text { Not } \\
\text { required }\end{array}$ & $<0.4$ & $<0.4$ & Not required & $<0.4$ & $\begin{array}{l}\text { Not } \\
\text { required }\end{array}$ & $\begin{array}{l}\text { Not } \\
\text { required }\end{array}$ & $\begin{array}{l}\text { Not } \\
\text { required }\end{array}$ & $\begin{array}{l}\text { Not } \\
\text { required }\end{array}$ & $\begin{array}{l}\text { Not } \\
\text { required }\end{array}$ & $\begin{array}{l}\text { Not } \\
\text { required }\end{array}$ & & $\begin{array}{l}\text { Not } \\
\text { required }\end{array}$ & $\begin{array}{l}\text { Not } \\
\text { required }\end{array}$ & $\begin{array}{l}\text { Not } \\
\text { required }\end{array}$ & $\begin{array}{l}\text { Not } \\
\text { required }\end{array}$ \\
\hline 1,2-Dichlorobenzene & $\mu \mathrm{g} / \mathrm{L}$ & $<0.4$ & $<0.4$ & $<0.4$ & Not required & $<0.4$ & $\begin{array}{l}\text { Not } \\
\text { required }\end{array}$ & $\begin{array}{l}\text { Not } \\
\text { required }\end{array}$ & $\begin{array}{l}\text { Not } \\
\text { required }\end{array}$ & $\begin{array}{l}\text { Not } \\
\text { required }\end{array}$ & $\begin{array}{l}\text { Not } \\
\text { required }\end{array}$ & $\begin{array}{l}\text { Not } \\
\text { required }\end{array}$ & & $\begin{array}{l}\text { Not } \\
\text { required }\end{array}$ & $\begin{array}{l}\text { Not } \\
\text { required }\end{array}$ & $\begin{array}{l}\text { Not } \\
\text { required }\end{array}$ & $\begin{array}{l}\text { Not } \\
\text { required }\end{array}$ \\
\hline 1,2-Dichloroethane & $\mu \mathrm{g} / \mathrm{L}$ & $<0.4$ & $<0.4$ & $<0.4$ & Not required & $<0.4$ & $\begin{array}{l}\begin{array}{l}\text { Not } \\
\text { required }\end{array} \\
\end{array}$ & $<0.5$ & $\begin{array}{l}\text { Not } \\
\text { required }\end{array}$ & \begin{tabular}{|l|} 
Not \\
required
\end{tabular} & $<0.5$ & $<0.5$ & & $<0.5$ & $<0.5$ & $<0.5$ & $<0.5$ \\
\hline 1,2-Dichloroethene & $\mu \mathrm{g} / \mathrm{L}$ & & & & & & & & & $\begin{array}{l}\text { Not } \\
\text { required }\end{array}$ & $<0.4$ & $<1.2$ & & $<0.4$ & $<1.2$ & $<1.2$ & $<1.2$ \\
\hline 1,2-Dichloropropane & $\mu \mathrm{g} / \mathrm{L}$ & $<0.4$ & $<0.4$ & $<0.4$ & Not required & $<0.4$ & $\begin{array}{l}\text { Not } \\
\text { required }\end{array}$ & $\begin{array}{l}\text { Not } \\
\text { required }\end{array}$ & $\begin{array}{l}\text { Not } \\
\text { required }\end{array}$ & $\begin{array}{l}\text { Not } \\
\text { required }\end{array}$ & $\begin{array}{l}\text { Not } \\
\text { required }\end{array}$ & $\begin{array}{l}\text { Not } \\
\text { required }\end{array}$ & & $\begin{array}{l}\text { Not } \\
\text { required }\end{array}$ & $\begin{array}{l}\text { Not } \\
\text { required }\end{array}$ & $\begin{array}{l}\text { Not } \\
\text { required }\end{array}$ & $\begin{array}{l}\text { Not } \\
\text { required }\end{array}$ \\
\hline $\begin{array}{l}\text { 1,4-Dichlorobenzene } \\
\text { (SVOA) }\end{array}$ & & & & & & 4 & 9 & $<5.6$ & $\mid<280$ & $\mid<280$ & 10 & 4 & & $\mid<56$ & 12 & $<5.6$ & 10 \\
\hline $\begin{array}{l}\text { 1,4-Dichlorobenzene } \\
\text { (VOA) }\end{array}$ & $\mu \mathrm{g} / \mathrm{L}$ & 8.9 & 8.7 & 10 & 7.7 & 6.8 & 8 & 5 & 9 & $<300$ & 5 & 5 & & 6 & 6 & 4 & 5 \\
\hline 1,4-Dioxane & $\mu \mathrm{g} / \mathrm{L}$ & $<50$ & $<40$ & $<1,000$ & 89 & 89 & 110 & 65 & 52 & $<1300$ & 40 & & 44 & 180 & 150 & 57 & 100 \\
\hline 1-Butanol & $\mu \mathrm{g} / \mathrm{L}$ & & & & & & & & & & & & & $<1500$ & $<150$ & $<150$ & $<150$ \\
\hline 2,4-Dichlorophenol & $\mu \mathrm{g} / \mathrm{L}$ & & & & & & & & & & & & & $<11$ & $<1.1$ & $<1.1$ & $<1.1$ \\
\hline 2,4-Dinitrotolulene & $\mu \mathrm{g} / \mathrm{L}$ & & & & & & & & & & & & & $<16$ & $<1.6$ & $<1.6$ & $<1.6$ \\
\hline
\end{tabular}




\begin{tabular}{|c|c|c|c|c|c|c|c|c|c|c|c|c|c|c|c|c|c|}
\hline $\begin{array}{c}\text { Analytical } \\
\text { Parameters }\end{array}$ & Units & \begin{tabular}{|c} 
1st \\
Quarter \\
1997 \\
\end{tabular} & $\begin{array}{c}\text { 2nd } \\
\text { Quarter } \\
1997 \\
\end{array}$ & \begin{tabular}{|c|} 
3rd \\
Quarter \\
1997 \\
\end{tabular} & $\begin{array}{c}\text { 4th } \\
\text { Quarter } \\
1997 \\
\end{array}$ & $\begin{array}{c}\text { 1st } \\
\text { Quarter } \\
1998 \\
\end{array}$ & $\begin{array}{c}\text { 2nd } \\
\text { Quarter } \\
1998 \\
\end{array}$ & $\begin{array}{c}\text { 3rd } \\
\text { Quarter } \\
1998 \\
\end{array}$ & \begin{tabular}{|c|c} 
4th \\
Quarter \\
1998 \\
\end{tabular} & $\begin{array}{c}\text { 1st } \\
\text { Quarter } \\
1999 \\
\end{array}$ & $\begin{array}{c}\text { 2nd } \\
\text { Quarter } \\
1999 \\
\end{array}$ & $\begin{array}{c}\text { 3rd } \\
\text { Quarter } \\
1999 \\
\end{array}$ & \begin{tabular}{|c|} 
3rd \\
Quarter \\
1999 \\
Resample \\
\end{tabular} & \begin{tabular}{|c} 
4th \\
Quarter \\
1999 \\
\end{tabular} & $\begin{array}{c}\text { 1st } \\
\text { Quarter } \\
2000\end{array}$ & $\begin{array}{c}\text { 2nd } \\
\text { Quarter } \\
\text { 2000 } \\
\end{array}$ & \begin{tabular}{|c} 
3rd \\
Quarter \\
2000 \\
\end{tabular} \\
\hline 2-Butanone (MEK) & $\mu \mathrm{g} / \mathrm{L}$ & 92 & 8.7 & 24 & 1.8 & \begin{tabular}{|l}
$\begin{array}{l}\text { Not } \\
\text { required }\end{array}$ \\
\end{tabular} & $<3.1$ & $<3.1$ & \begin{tabular}{|l} 
Not \\
required
\end{tabular} & \begin{tabular}{|l} 
Not \\
required
\end{tabular} & $<3.1$ & $<3.1$ & & $<3.1$ & $<3.1$ & 12 & 17 \\
\hline 2-Butoxyethanol & $\mu \mathrm{g} / \mathrm{L}$ & & & & & & & & & & & & & $<12$ & $<1.2$ & 2 & $<1.2$ \\
\hline 2-Chlorophenol & $\mu \mathrm{g} / \mathrm{L}$ & & & & & & & & & & & & & $<9$ & $<0.9$ & $<0.9$ & $<0.9$ \\
\hline 2-Hexanone & $\mu \mathrm{g} / \mathrm{L}$ & 11 & \begin{tabular}{|l|l|}
$\begin{array}{l}\text { Not } \\
\text { required }\end{array}$ \\
\end{tabular} & $<8$ & Not required & \begin{tabular}{|l|l|}
$\begin{array}{l}\text { Not } \\
\text { required }\end{array}$ \\
\end{tabular} & $<1.1$ & $<1.1$ & \begin{tabular}{|l|l|}
$\begin{array}{l}\text { Not } \\
\text { required }\end{array}$ \\
\end{tabular} & \begin{tabular}{|l|l|}
$\begin{array}{l}\text { Not } \\
\text { required }\end{array}$ \\
\end{tabular} & $<1.1$ & $<1.1$ & & $<1.1$ & $<1.1$ & $<1.1$ & $<1.1$ \\
\hline 2-Methylphenol & $\mu \mathrm{g} / \mathrm{L}$ & $<0.47$ & $<0.45$ & 1.1 & 1.8 & 0.59 & $<1$ & 1 & $<80$ & $<80$ & $<1.6$ & $<1.6$ & & $<16$ & $<1.6$ & $<1.6$ & $<1.6$ \\
\hline 2-Methylpyridine & $\mu \mathrm{g} / \mathrm{L}$ & & & & & & & & & & & & & $<6$ & $<0.6$ & $<0.6$ & $<0.6$ \\
\hline 2-Nitrophenol & $\mu \mathrm{g} / \mathrm{L}$ & & & & & & & & & & & & & $<17$ & $<1.7$ & $<1.7$ & $<1.7$ \\
\hline 2-Pentanone & $\mu \mathrm{g} / \mathrm{L}$ & & & & & & & & & & & & & $<2.3$ & $<2.3$ & $<2.3$ & 12 \\
\hline 3-\& 4-Methylphenol & $\mu \mathrm{g} / \mathrm{L}$ & 880 & 690 & 91 & 3.9 & 0.63 & $<1.3$ & $<2.1$ & $<110$ & $<110$ & $<2.1$ & $<2.1$ & & $<21$ & $<2.1$ & $<2.1$ & $<2.1$ \\
\hline $\begin{array}{l}\text { 4-Chloro-3- } \\
\text { methylphenol }\end{array}$ & $\mu \mathrm{g} / \mathrm{L}$ & & & & & & & & & & & & & $<7$ & $<0.7$ & $<0.7$ & $<0.7$ \\
\hline 4-Methyl-2-pentanone & $\mu \mathrm{g} / \mathrm{L}$ & 16 & 6.9 & 1.4 & $<8$ & \begin{tabular}{|l|}
$\begin{array}{l}\text { Not } \\
\text { required }\end{array}$ \\
\end{tabular} & $<0.9$ & $<0.9$ & \begin{tabular}{|l|}
$\begin{array}{l}\text { Not } \\
\text { required }\end{array}$ \\
\end{tabular} & \begin{tabular}{|l|}
$\begin{array}{l}\text { Not } \\
\text { required }\end{array}$ \\
\end{tabular} & $<0.9$ & $<0.9$ & & $<0.9$ & $<0.9$ & $<0.9$ & $<0.9$ \\
\hline 4-Nitrophenol & $\mu \mathrm{g} / \mathrm{L}$ & & & & & & & & & & & & & $<11$ & $<1.1$ & $<1.1$ & $<1.1$ \\
\hline Acenaphthene & $\mu \mathrm{g} / \mathrm{L}$ & & & & & & & & & & & & & $<35$ & $<3.5$ & $<3.5$ & $<3.5$ \\
\hline Acetone & $\mu \mathrm{g} / \mathrm{L}$ & $<8$ & 29 & 85 & 9.4 & \begin{tabular}{|l|}
$\begin{array}{l}\text { Not } \\
\text { required }\end{array}$ \\
\end{tabular} & 8 & 8 & \begin{tabular}{|l|}
$\begin{array}{l}\text { Not } \\
\text { required }\end{array}$ \\
\end{tabular} & \begin{tabular}{|l|}
$\begin{array}{l}\text { Not } \\
\text { required }\end{array}$ \\
\end{tabular} & 22 & 15 & & 12 & 8 & 19 & 20 \\
\hline Acetophenone & $\mu \mathrm{g} / \mathrm{L}$ & & & & & & & & & & & & & $<12$ & $<1.2$ & $<1.2$ & $<1.2$ \\
\hline Acryonitrile & $\mu \mathrm{g} / \mathrm{L}$ & \begin{tabular}{|l|}
$\begin{array}{l}\text { Not } \\
\text { required }\end{array}$ \\
\end{tabular} & \begin{tabular}{|l|}
$\begin{array}{l}\text { Not } \\
\text { required }\end{array}$ \\
\end{tabular} & $<2$ & Not required & \begin{tabular}{|l|}
$\begin{array}{l}\text { Not } \\
\text { required }\end{array}$ \\
\end{tabular} & \begin{tabular}{|l|}
$\begin{array}{l}\text { Not } \\
\text { required }\end{array}$ \\
\end{tabular} & \begin{tabular}{|l|}
$\begin{array}{l}\text { Not } \\
\text { required }\end{array}$ \\
\end{tabular} & \begin{tabular}{|l|}
$\begin{array}{l}\text { Not } \\
\text { required }\end{array}$ \\
\end{tabular} & \begin{tabular}{|l|} 
Not \\
required
\end{tabular} & \begin{tabular}{|l|}
$\begin{array}{l}\text { Not } \\
\text { required }\end{array}$ \\
\end{tabular} & \begin{tabular}{|l|}
$\begin{array}{l}\text { Not } \\
\text { required }\end{array}$ \\
\end{tabular} & & \begin{tabular}{|l|}
$\begin{array}{l}\text { Not } \\
\text { required }\end{array}$ \\
\end{tabular} & \begin{tabular}{|l|}
$\begin{array}{l}\text { Not } \\
\text { required }\end{array}$ \\
\end{tabular} & \begin{tabular}{|l|}
$\begin{array}{l}\text { Not } \\
\text { required }\end{array}$ \\
\end{tabular} & \begin{tabular}{|l|}
$\begin{array}{l}\text { Not } \\
\text { required }\end{array}$ \\
\end{tabular} \\
\hline Benzene & $\mu \mathrm{g} / \mathrm{L}$ & $<0.4$ & $<0.4$ & $<0.4$ & Not required & $<0.4$ & $<0.5$ & $<0.5$ & \begin{tabular}{|l|}
$\begin{array}{l}\text { Not } \\
\text { required }\end{array}$ \\
\end{tabular} & \begin{tabular}{|l|}
$\begin{array}{l}\text { Not } \\
\text { required }\end{array}$ \\
\end{tabular} & $<0.5$ & $<0.5$ & & $<0.5$ & $<0.5$ & $<0.5$ & $<0.5$ \\
\hline Benzothiazole & $\mu \mathrm{g} / \mathrm{L}$ & & & & & & & & & & & & & $<10$ & $<1$ & $<1$ & $<1$ \\
\hline Benzyl Alcohol & $\mu \mathrm{g} / \mathrm{L}$ & & & & & & & & & & & & & $<9$ & $<0.9$ & $<0.9$ & $<0.9$ \\
\hline $\begin{array}{l}\text { Bis(2-Ethylhexyl) } \\
\text { phtalate }\end{array}$ & $\mu \mathrm{g} / \mathrm{L}$ & & & & & & & & & & & 18 & & $<35$ & 1 & $<3.5$ & $<3.5$ \\
\hline $\begin{array}{l}\text { Bromochloro- } \\
\text { methane }\end{array}$ & $\mu \mathrm{g} / \mathrm{L}$ & $\begin{array}{l}\text { Not } \\
\text { required }\end{array}$ & $<0.4$ & $<0.4$ & Not required & $<0.4$ & $\begin{array}{l}\text { Not } \\
\text { required }\end{array}$ & \begin{tabular}{|l} 
Not \\
required
\end{tabular} & $\begin{array}{l}\text { Not } \\
\text { required }\end{array}$ & $\begin{array}{l}\text { Not } \\
\text { required }\end{array}$ & \begin{tabular}{|l|} 
Not \\
required
\end{tabular} & \begin{tabular}{|l} 
Not \\
required
\end{tabular} & & \begin{tabular}{|l|}
$\begin{array}{l}\text { Not } \\
\text { required }\end{array}$ \\
\end{tabular} & \begin{tabular}{|l|} 
Not \\
required
\end{tabular} & \begin{tabular}{|l|}
$\begin{array}{l}\text { Not } \\
\text { required }\end{array}$ \\
\end{tabular} & $\begin{array}{l}\text { Not } \\
\text { required }\end{array}$ \\
\hline $\begin{array}{l}\text { Bromodichloro- } \\
\text { methane }\end{array}$ & $\mu \mathrm{g} / \mathrm{L}$ & $<0.4$ & $<0.4$ & $<0.4$ & Not required & $<0.4$ & $<0.4$ & $<0.4$ & $\begin{array}{l}\text { Not } \\
\text { required }\end{array}$ & $\begin{array}{l}\text { Not } \\
\text { required }\end{array}$ & $<0.4$ & $<0.4$ & & $<0.4$ & $<0.4$ & $<0.4$ & $<0.4$ \\
\hline Bromoform & $\mu \mathrm{g} / \mathrm{L}$ & $<0.4$ & $<0.4$ & $<0.4$ & Not required & $<0.4$ & \begin{tabular}{|l|} 
Not \\
required
\end{tabular} & \begin{tabular}{|l|} 
Not \\
required
\end{tabular} & $\begin{array}{l}\text { Not } \\
\text { required }\end{array}$ & \begin{tabular}{|l|} 
Not \\
required
\end{tabular} & \begin{tabular}{|l|} 
Not \\
required
\end{tabular} & \begin{tabular}{|l|} 
Not \\
required
\end{tabular} & & \begin{tabular}{|l|} 
Not \\
required
\end{tabular} & \begin{tabular}{|l|} 
Not \\
required
\end{tabular} & \begin{tabular}{|l|}
$\begin{array}{l}\text { Not } \\
\text { required }\end{array}$ \\
\end{tabular} & $\begin{array}{l}\text { Not } \\
\text { required }\end{array}$ \\
\hline Bromomethane & $\mu \mathrm{g} / \mathrm{L}$ & $<0.4$ & \begin{tabular}{|l|} 
Not \\
required
\end{tabular} & $<0.4$ & Not required & \begin{tabular}{|l|} 
Not \\
required
\end{tabular} & \begin{tabular}{|l|} 
Not \\
required
\end{tabular} & \begin{tabular}{|l|} 
Not \\
required
\end{tabular} & \begin{tabular}{|l|}
$\begin{array}{l}\text { Not } \\
\text { required }\end{array}$ \\
\end{tabular} & $\begin{array}{l}\text { Not } \\
\text { required }\end{array}$ & $\begin{array}{l}\text { Not } \\
\text { required }\end{array}$ & \begin{tabular}{|l|} 
Not \\
required
\end{tabular} & & \begin{tabular}{|l|} 
Not \\
required
\end{tabular} & $\begin{array}{l}\text { Not } \\
\text { required }\end{array}$ & \begin{tabular}{|l|} 
Not \\
required
\end{tabular} & \begin{tabular}{|l|} 
Not \\
required
\end{tabular} \\
\hline
\end{tabular}




\begin{tabular}{|c|c|c|c|c|c|c|c|c|c|c|c|c|c|c|c|c|c|}
\hline $\begin{array}{c}\text { Analytical } \\
\text { Parameters }\end{array}$ & Units & \begin{tabular}{|c} 
1st \\
Quarter \\
1997 \\
\end{tabular} & $\begin{array}{c}\text { 2nd } \\
\text { Quarter } \\
1997 \\
\end{array}$ & \begin{tabular}{|c|} 
3rd \\
Quarter \\
1997 \\
\end{tabular} & $\begin{array}{c}\text { 4th } \\
\text { Quarter } \\
1997 \\
\end{array}$ & \begin{tabular}{|c} 
1st \\
Quarter \\
1998 \\
\end{tabular} & $\begin{array}{c}\text { 2nd } \\
\text { Quarter } \\
1998 \\
\end{array}$ & $\begin{array}{c}\text { 3rd } \\
\text { Quarter } \\
1998 \\
\end{array}$ & \begin{tabular}{|c|c} 
4th \\
Quarter \\
1998 \\
\end{tabular} & $\begin{array}{c}\text { 1st } \\
\text { Quarter } \\
1999 \\
\end{array}$ & $\begin{array}{c}\text { 2nd } \\
\text { Quarter } \\
1999 \\
\end{array}$ & $\begin{array}{c}\text { 3rd } \\
\text { Quarter } \\
1999 \\
\end{array}$ & \begin{tabular}{|c} 
3rd \\
Quarter \\
1999 \\
Resample \\
\end{tabular} & \begin{tabular}{|c} 
4th \\
Quarter \\
1999
\end{tabular} & $\begin{array}{c}\text { 1st } \\
\text { Quarter } \\
2000\end{array}$ & $\begin{array}{c}\text { 2nd } \\
\text { Quarter } \\
2000 \\
\end{array}$ & \begin{tabular}{|c} 
3rd \\
Quarter \\
2000 \\
\end{tabular} \\
\hline Carbon Disulfide & $\mu \mathrm{g} / \mathrm{L}$ & \begin{tabular}{|l}
$\begin{array}{l}\text { Not } \\
\text { required }\end{array}$ \\
\end{tabular} & $\begin{array}{l}\begin{array}{l}\text { Not } \\
\text { required }\end{array} \\
\end{array}$ & $<0.4$ & Not required & \begin{tabular}{|l}
$\begin{array}{l}\text { Not } \\
\text { required }\end{array}$ \\
\end{tabular} & $<0.6$ & $<0.6$ & $\begin{array}{l}\begin{array}{l}\text { Not } \\
\text { required }\end{array} \\
\end{array}$ & \begin{tabular}{|l}
$\begin{array}{l}\text { Not } \\
\text { required }\end{array}$ \\
\end{tabular} & $<0.6$ & $<0.6$ & & $<0.6$ & $<0.6$ & $<0.6$ & $<0.6$ \\
\hline Carbon Tetrachloride & $\mu \mathrm{g} / \mathrm{L}$ & $<0.4$ & $<0.4$ & $<0.4$ & $<0.4$ & $<0.4$ & $<0.6$ & $<0.6$ & $<0.6$ & $<300$ & $<0.6$ & $<0.6$ & & $<0.6$ & $<0.6$ & $<0.6$ & $<0.6$ \\
\hline Chlorobenzene & $\mu \mathrm{g} / \mathrm{L}$ & $<0.4$ & $<0.4$ & $<0.4$ & Not required & $<0.4$ & $<0.4$ & $<0.4$ & $\begin{array}{l}\text { Not } \\
\text { required }\end{array}$ & \begin{tabular}{|l|} 
Not \\
required
\end{tabular} & $<0.4$ & $<0.4$ & & $<0.4$ & $<0.4$ & $<0.4$ & $<0.4$ \\
\hline Chloroethane & $\mu \mathrm{g} / \mathrm{L}$ & 4.8 & 4 & 11 & 4.9 & 2.9 & \begin{tabular}{|l|}
$\begin{array}{l}\text { Not } \\
\text { required }\end{array}$ \\
\end{tabular} & \begin{tabular}{|l|}
$\begin{array}{l}\text { Not } \\
\text { required }\end{array}$ \\
\end{tabular} & \begin{tabular}{|l|}
$\begin{array}{l}\text { Not } \\
\text { required }\end{array}$ \\
\end{tabular} & \begin{tabular}{|l|}
$\begin{array}{l}\text { Not } \\
\text { required }\end{array}$ \\
\end{tabular} & \begin{tabular}{|l|}
$\begin{array}{l}\text { Not } \\
\text { required }\end{array}$ \\
\end{tabular} & \begin{tabular}{|l|}
$\begin{array}{l}\text { Not } \\
\text { required }\end{array}$ \\
\end{tabular} & & \begin{tabular}{|l|l}
$\begin{array}{l}\text { Not } \\
\text { required }\end{array}$ \\
\end{tabular} & \begin{tabular}{|l|}
$\begin{array}{l}\text { Not } \\
\text { required }\end{array}$ \\
\end{tabular} & \begin{tabular}{|l|}
$\begin{array}{l}\text { Not } \\
\text { required }\end{array}$ \\
\end{tabular} & \begin{tabular}{|l|}
$\begin{array}{l}\text { Not } \\
\text { required }\end{array}$ \\
\end{tabular} \\
\hline Chloroform & $\mu \mathrm{g} / \mathrm{L}$ & $<0.4$ & $<0.4$ & $<0.4$ & Not required & $<0.4$ & $<0.4$ & $<0.4$ & $<0.4$ & $<200$ & $<0.4$ & $<0.4$ & & $<0.4$ & $<0.4$ & $<0.4$ & $<0.4$ \\
\hline Chloromethane & $\mu \mathrm{g} / \mathrm{L}$ & $<0.4$ & $<0.4$ & 6.1 & Not required & $<0.4$ & \begin{tabular}{|l} 
Not \\
required
\end{tabular} & \begin{tabular}{|l|}
$\begin{array}{l}\text { Not } \\
\text { required }\end{array}$ \\
\end{tabular} & \begin{tabular}{|l|}
$\begin{array}{l}\text { Not } \\
\text { required }\end{array}$ \\
\end{tabular} & \begin{tabular}{|l} 
Not \\
required
\end{tabular} & \begin{tabular}{|l|}
$\begin{array}{l}\text { Not } \\
\text { required }\end{array}$ \\
\end{tabular} & \begin{tabular}{|l|}
$\begin{array}{l}\text { Not } \\
\text { required }\end{array}$ \\
\end{tabular} & & \begin{tabular}{|l} 
Not \\
required
\end{tabular} & \begin{tabular}{|l|} 
Not \\
required
\end{tabular} & \begin{tabular}{|l|}
$\begin{array}{l}\text { Not } \\
\text { required }\end{array}$ \\
\end{tabular} & \begin{tabular}{|l|}
$\begin{array}{l}\text { Not } \\
\text { required }\end{array}$ \\
\end{tabular} \\
\hline \begin{tabular}{|l} 
Cis-1,2- \\
Dichloroethylene \\
\end{tabular} & $\mu \mathrm{g} / \mathrm{L}$ & 1.1 & 0.88 & 1.8 & Not required & $\begin{array}{l}\text { Not } \\
\text { required }\end{array}$ & $\begin{array}{l}\text { Not } \\
\text { required }\end{array}$ & $\begin{array}{l}\text { Not } \\
\text { required }\end{array}$ & $\begin{array}{l}\text { Not } \\
\text { required }\end{array}$ & \begin{tabular}{|l} 
Not \\
required
\end{tabular} & $<1.2$ & $\begin{array}{l}\text { Not } \\
\text { required }\end{array}$ & & $\begin{array}{l}\text { Not } \\
\text { required }\end{array}$ & \begin{tabular}{|l} 
Not \\
required
\end{tabular} & \begin{tabular}{|l} 
Not \\
required
\end{tabular} & \begin{tabular}{|l} 
Not \\
required
\end{tabular} \\
\hline \begin{tabular}{|l|} 
Cis-1,3- \\
Dichloropropene \\
\end{tabular} & $\mu \mathrm{g} / \mathrm{L}$ & $<0.4$ & \begin{tabular}{|l|}
$\begin{array}{l}\text { Not } \\
\text { required }\end{array}$ \\
\end{tabular} & $<0.4$ & Not required & $<0.4$ & $\begin{array}{l}\text { Not } \\
\text { required }\end{array}$ & \begin{tabular}{|l|}
$\begin{array}{l}\text { Not } \\
\text { required }\end{array}$ \\
\end{tabular} & \begin{tabular}{|l|}
$\begin{array}{l}\text { Not } \\
\text { required }\end{array}$ \\
\end{tabular} & \begin{tabular}{|l|}
$\begin{array}{l}\text { Not } \\
\text { required }\end{array}$ \\
\end{tabular} & $\begin{array}{l}\text { Not } \\
\text { required }\end{array}$ & \begin{tabular}{|l|}
$\begin{array}{l}\text { Not } \\
\text { required }\end{array}$ \\
\end{tabular} & & $\begin{array}{l}\text { Not } \\
\text { required }\end{array}$ & \begin{tabular}{|l|}
$\begin{array}{l}\text { Not } \\
\text { required }\end{array}$ \\
\end{tabular} & \begin{tabular}{|l|}
$\begin{array}{l}\text { Not } \\
\text { required }\end{array}$ \\
\end{tabular} & \begin{tabular}{|l|}
$\begin{array}{l}\text { Not } \\
\text { required }\end{array}$ \\
\end{tabular} \\
\hline Decane & $\mu \mathrm{g} / \mathrm{L}$ & & & & & & & & & & & & & $<24$ & $<2.4$ & $<2.4$ & $<2.4$ \\
\hline \begin{tabular}{|l} 
Dibromochloro- \\
methane
\end{tabular} & $\mu \mathrm{g} / \mathrm{L}$ & $<0.4$ & $<0.4$ & $<0.4$ & Not required & $<0.4$ & \begin{tabular}{|l} 
Not \\
required
\end{tabular} & \begin{tabular}{|l|}
$\begin{array}{l}\text { Not } \\
\text { required }\end{array}$ \\
\end{tabular} & \begin{tabular}{|l|}
$\begin{array}{l}\text { Not } \\
\text { required }\end{array}$ \\
\end{tabular} & \begin{tabular}{|l} 
Not \\
required
\end{tabular} & \begin{tabular}{|l} 
Not \\
required
\end{tabular} & \begin{tabular}{|l} 
Not \\
required
\end{tabular} & & \begin{tabular}{|l} 
Not \\
required
\end{tabular} & \begin{tabular}{|l} 
Not \\
required
\end{tabular} & \begin{tabular}{|l|}
$\begin{array}{l}\text { Not } \\
\text { required }\end{array}$ \\
\end{tabular} & \begin{tabular}{|l|}
$\begin{array}{l}\text { Not } \\
\text { required }\end{array}$ \\
\end{tabular} \\
\hline Dibromomethane & $\mu \mathrm{g} / \mathrm{L}$ & \begin{tabular}{|l|}
$\begin{array}{l}\text { Not } \\
\text { required }\end{array}$ \\
\end{tabular} & $<0.4$ & $<0.4$ & Not required & $<0.4$ & \begin{tabular}{|l|}
$\begin{array}{l}\text { Not } \\
\text { required }\end{array}$ \\
\end{tabular} & \begin{tabular}{|l|}
$\begin{array}{l}\text { Not } \\
\text { required }\end{array}$ \\
\end{tabular} & \begin{tabular}{|l|}
$\begin{array}{l}\text { Not } \\
\text { required }\end{array}$ \\
\end{tabular} & \begin{tabular}{|l|}
$\begin{array}{l}\text { Not } \\
\text { required }\end{array}$ \\
\end{tabular} & \begin{tabular}{|l|}
$\begin{array}{l}\text { Not } \\
\text { required }\end{array}$ \\
\end{tabular} & \begin{tabular}{|l|}
$\begin{array}{l}\text { Not } \\
\text { required }\end{array}$ \\
\end{tabular} & & $\begin{array}{l}\text { Not } \\
\text { required }\end{array}$ & \begin{tabular}{|l|}
$\begin{array}{l}\text { Not } \\
\text { required }\end{array}$ \\
\end{tabular} & \begin{tabular}{|l|}
$\begin{array}{l}\text { Not } \\
\text { required }\end{array}$ \\
\end{tabular} & \begin{tabular}{|l|}
$\begin{array}{l}\text { Not } \\
\text { required }\end{array}$ \\
\end{tabular} \\
\hline Di-n-Octylphthalene & $\mu \mathrm{g} / \mathrm{L}$ & & & & & & & & & & & & & $<18$ & $<1.8$ & $<1.8$ & $<1.8$ \\
\hline Dodecane & $\mu \mathrm{g} / \mathrm{L}$ & & & & & & & & & & & & & $<27$ & $<2.7$ & $<2.7$ & $<2.7$ \\
\hline Ethyl Cyanide & $\mu \mathrm{g} / \mathrm{L}$ & & & & & & & & & & & & & $<3$ & $<3$ & $<3$ & $<3$ \\
\hline Ethylbenzene & $\mu \mathrm{g} / \mathrm{L}$ & 1.1 & $<0.4$ & $<0.4$ & $<0.4$ & $<0.4$ & \begin{tabular}{|l|}
$\begin{array}{l}\text { Not } \\
\text { required }\end{array}$ \\
\end{tabular} & \begin{tabular}{|l|}
$\begin{array}{l}\text { Not } \\
\text { required }\end{array}$ \\
\end{tabular} & \begin{tabular}{|l|}
$\begin{array}{l}\text { Not } \\
\text { required }\end{array}$ \\
\end{tabular} & \begin{tabular}{|l|}
$\begin{array}{l}\text { Not } \\
\text { required }\end{array}$ \\
\end{tabular} & \begin{tabular}{|l|}
$\begin{array}{l}\text { Not } \\
\text { required }\end{array}$ \\
\end{tabular} & \begin{tabular}{|l|}
$\begin{array}{l}\text { Not } \\
\text { required }\end{array}$ \\
\end{tabular} & & \begin{tabular}{|l}
$\begin{array}{l}\text { Not } \\
\text { required }\end{array}$ \\
\end{tabular} & \begin{tabular}{|l|}
$\begin{array}{l}\text { Not } \\
\text { required }\end{array}$ \\
\end{tabular} & \begin{tabular}{|l|}
$\begin{array}{l}\text { Not } \\
\text { required }\end{array}$ \\
\end{tabular} & \begin{tabular}{|l|}
$\begin{array}{l}\text { Not } \\
\text { required }\end{array}$ \\
\end{tabular} \\
\hline Hexachloroethane & $\mu \mathrm{g} / \mathrm{L}$ & & & & & & & & & & & & & $<63$ & $<6.3$ & $<6.3$ & $<6.3$ \\
\hline Methyl Iodide & $\mu \mathrm{g} / \mathrm{L}$ & \begin{tabular}{|l|} 
Not \\
required
\end{tabular} & $\begin{array}{l}\text { Not } \\
\text { required }\end{array}$ & $<0.4$ & Not required & $\begin{array}{l}\text { Not } \\
\text { required }\end{array}$ & $\begin{array}{l}\text { Not } \\
\text { required }\end{array}$ & $\begin{array}{l}\text { Not } \\
\text { required }\end{array}$ & $\begin{array}{l}\text { Not } \\
\text { required }\end{array}$ & \begin{tabular}{|l|} 
Not \\
required
\end{tabular} & $\begin{array}{l}\text { Not } \\
\text { required }\end{array}$ & $\begin{array}{l}\text { Not } \\
\text { required }\end{array}$ & & $\begin{array}{l}\text { Not } \\
\text { required }\end{array}$ & $\begin{array}{l}\text { Not } \\
\text { required }\end{array}$ & $\begin{array}{l}\text { Not } \\
\text { required }\end{array}$ & $\begin{array}{l}\text { Not } \\
\text { required }\end{array}$ \\
\hline Methylene Chloride & $\mu \mathrm{g} / \mathrm{L}$ & $<0.4$ & $<0.4$ & 17 & 2.8 & 1.8 & 1 & 0.6 & 0.7 & $<200$ & 4 & $<0.4$ & & $<0.4$ & $<0.4$ & $<0.4$ & $<0.4$ \\
\hline Napthalene & $\mu \mathrm{g} / \mathrm{L}$ & & & & & & & & & & & & & $<42$ & $<4.2$ & $<4.2$ & $<4.2$ \\
\hline \begin{tabular}{|l|}
$\mathrm{N}-$ \\
Nitrosodimethylamine \\
\end{tabular} & $\mu \mathrm{g} / \mathrm{L}$ & & & & & & & & & & & & & $<8$ & $<0.8$ & $<0.8$ & $<0.8$ \\
\hline \begin{tabular}{|l|} 
N-Nitroso-di-n- \\
Propylamine \\
\end{tabular} & $\mu \mathrm{g} / \mathrm{L}$ & & & & & & & & & & & & & $<14$ & $<1.4$ & $<1.4$ & $<1.4$ \\
\hline Pentachlorophenol & $\mu \mathrm{g} / \mathrm{L}$ & & & & & & & & & & & & & & & $<2.6$ & $<2.6$ \\
\hline Phenol & $\mu \mathrm{g} / \mathrm{L}$ & 96 & 62 & 1 & 0.2 & $<0.45$ & $<0.42$ & $<2$ & $<100$ & $<100$ & $<2$ & $<2$ & & $<20$ & $<2$ & $<2$ & $<2$ \\
\hline Pyrene & $\mu \mathrm{g} / \mathrm{L}$ & & & & & & & & & & & & & $<5$ & $<0.5$ & $<0.5$ & $<0.5$ \\
\hline
\end{tabular}




\begin{tabular}{|c|c|c|c|c|c|c|c|c|c|c|c|c|c|c|c|c|c|}
\hline $\begin{array}{l}\text { Analytical } \\
\text { Parameters }\end{array}$ & Units & $\begin{array}{c}\text { 1st } \\
\text { Quarter } \\
1997\end{array}$ & $\begin{array}{c}\text { 2nd } \\
\text { Quarter } \\
1997\end{array}$ & $\begin{array}{c}\text { 3rd } \\
\text { Quarter } \\
1997\end{array}$ & $\begin{array}{c}\text { 4th } \\
\text { Quarter } \\
1997\end{array}$ & $\begin{array}{c}\text { 1st } \\
\text { Quarter } \\
1998\end{array}$ & $\begin{array}{c}\text { 2nd } \\
\text { Quarter } \\
1998\end{array}$ & $\begin{array}{c}\text { 3rd } \\
\text { Quarter } \\
1998\end{array}$ & $\begin{array}{c}\text { 4th } \\
\text { Quarter } \\
1998\end{array}$ & $\begin{array}{c}\text { 1st } \\
\text { Quarter } \\
1999\end{array}$ & $\begin{array}{c}\text { 2nd } \\
\text { Quarter } \\
1999\end{array}$ & $\begin{array}{c}\text { 3rd } \\
\text { Quarter } \\
1999\end{array}$ & \begin{tabular}{|c|} 
3rd \\
Quarter \\
1999 \\
Resample
\end{tabular} & $\begin{array}{c}\text { 4th } \\
\text { Quarter } \\
1999\end{array}$ & $\begin{array}{c}\text { 1st } \\
\text { Quarter } \\
2000\end{array}$ & $\begin{array}{c}\text { 2nd } \\
\text { Quarter } \\
2000\end{array}$ & $\begin{array}{c}\text { 3rd } \\
\text { Quarter } \\
2000\end{array}$ \\
\hline Styrene & $\mu \mathrm{g} / \mathrm{L}$ & $\begin{array}{l}\begin{array}{l}\text { Not } \\
\text { required }\end{array} \\
\end{array}$ & $<0.4$ & $<0.4$ & Not required & $<0.4$ & $\begin{array}{l}\begin{array}{l}\text { Not } \\
\text { required }\end{array} \\
\end{array}$ & $\begin{array}{l}\begin{array}{l}\text { Not } \\
\text { required }\end{array} \\
\end{array}$ & $\begin{array}{l}\begin{array}{l}\text { Not } \\
\text { required }\end{array} \\
\end{array}$ & \begin{tabular}{|l}
$\begin{array}{l}\text { Not } \\
\text { required }\end{array}$ \\
\end{tabular} & $\begin{array}{l}\begin{array}{l}\text { Not } \\
\text { required }\end{array} \\
\end{array}$ & $\begin{array}{l}\begin{array}{l}\text { Not } \\
\text { required }\end{array} \\
\end{array}$ & & $\begin{array}{l}\begin{array}{l}\text { Not } \\
\text { required }\end{array} \\
\end{array}$ & $\begin{array}{l}\begin{array}{l}\text { Not } \\
\text { required }\end{array} \\
\end{array}$ & $\begin{array}{l}\begin{array}{l}\text { Not } \\
\text { required }\end{array} \\
\end{array}$ & $\begin{array}{l}\begin{array}{l}\text { Not } \\
\text { required }\end{array} \\
\end{array}$ \\
\hline Tetrachloroethene & $\mu \mathrm{g} / \mathrm{L}$ & $<0.4$ & $<0.4$ & $<0.4$ & $<0.4$ & 7.2 & \begin{tabular}{|l|} 
Not \\
required
\end{tabular} & $<0.5$ & 84 & $<250$ & $<0.5$ & $<0.5$ & & $<0.5$ & $<0.5$ & $<0.5$ & $<0.5$ \\
\hline Tetradecane & $\mu \mathrm{g} / \mathrm{L}$ & & & & & & & & & & & & & $<30$ & $<3$ & $<3$ & $<3$ \\
\hline Tetrahydrofuran & $\mu \mathrm{g} / \mathrm{L}$ & & & & & & & & & \begin{tabular}{|l|}
$\begin{array}{l}\text { Not } \\
\text { required }\end{array}$ \\
\end{tabular} & 24 & 22 & & 22 & 24 & 21 & 21 \\
\hline Toluene & $\mu \mathrm{g} / \mathrm{L}$ & 20 & 85 & 13 & 2.4 & 6.3 & 1 & 0.7 & 1 & $<350$ & $<0.7$ & $<0.7$ & & $<0.7$ & $<0.7$ & $<0.7$ & $<0.7$ \\
\hline Total Methylphenols & $\mu \mathrm{g} / \mathrm{L}$ & & & & & & & & & & & & & $<36$ & $<3.6$ & $<3.6$ & $<3.6$ \\
\hline Total Xylenes & $\mu \mathrm{g} / \mathrm{L}$ & 1.91 & 0.58 & 0.53 & 0.46 & $<0.8$ & $<1.2$ & $<1.2$ & 1 & $<600$ & $<1.2$ & $<1.2$ & & $<1.2$ & $<1.2$ & $<1.2$ & $<1.2$ \\
\hline $\begin{array}{l}\text { Trans-1,2- } \\
\text { Dichloroethylene }\end{array}$ & $\mu \mathrm{g} / \mathrm{L}$ & $<0.4$ & $<0.4$ & $<0.4$ & Not required & $\begin{array}{l}\text { Not } \\
\text { required }\end{array}$ & $\begin{array}{l}\text { Not } \\
\text { required }\end{array}$ & $\begin{array}{l}\text { Not } \\
\text { required }\end{array}$ & $\begin{array}{l}\text { Not } \\
\text { required }\end{array}$ & $\begin{array}{l}\text { Not } \\
\text { required }\end{array}$ & $\begin{array}{l}\text { Not } \\
\text { required }\end{array}$ & $\begin{array}{l}\text { Not } \\
\text { required }\end{array}$ & & $\begin{array}{l}\text { Not } \\
\text { required }\end{array}$ & $\begin{array}{l}\text { Not } \\
\text { required }\end{array}$ & $\begin{array}{l}\text { Not } \\
\text { required }\end{array}$ & $\begin{array}{l}\text { Not } \\
\text { required }\end{array}$ \\
\hline $\begin{array}{l}\text { Trans-1,3- } \\
\text { Dichloropropene }\end{array}$ & $\mu \mathrm{g} / \mathrm{L}$ & $<0.4$ & $\begin{array}{l}\text { Not } \\
\text { required }\end{array}$ & $\begin{array}{l}\text { Not } \\
\text { required }\end{array}$ & Not required & $<0.4$ & $\begin{array}{l}\text { Not } \\
\text { required }\end{array}$ & $\begin{array}{l}\text { Not } \\
\text { required }\end{array}$ & $\begin{array}{l}\text { Not } \\
\text { required }\end{array}$ & $\begin{array}{l}\text { Not } \\
\text { required }\end{array}$ & $\begin{array}{l}\text { Not } \\
\text { required }\end{array}$ & $\begin{array}{l}\text { Not } \\
\text { required }\end{array}$ & & \begin{tabular}{|l|} 
Not \\
required
\end{tabular} & $\begin{array}{l}\text { Not } \\
\text { required }\end{array}$ & $\begin{array}{l}\text { Not } \\
\text { required }\end{array}$ & $\begin{array}{l}\text { Not } \\
\text { required }\end{array}$ \\
\hline $\begin{array}{l}\text { Trans-1,4-Dichloro- } \\
\text { 2-butene }\end{array}$ & $\mu \mathrm{g} / \mathrm{L}$ & \begin{tabular}{|l} 
Not \\
required
\end{tabular} & \begin{tabular}{|l|} 
Not \\
required
\end{tabular} & $<2$ & Not required & \begin{tabular}{|l|}
$\begin{array}{l}\text { Not } \\
\text { required }\end{array}$ \\
\end{tabular} & \begin{tabular}{|l|} 
Not \\
required
\end{tabular} & \begin{tabular}{|l|} 
Not \\
required
\end{tabular} & \begin{tabular}{|l|} 
Not \\
required
\end{tabular} & \begin{tabular}{|l|} 
Not \\
required
\end{tabular} & \begin{tabular}{|l|} 
Not \\
required
\end{tabular} & \begin{tabular}{|l|} 
Not \\
required
\end{tabular} & & \begin{tabular}{|l|} 
Not \\
required
\end{tabular} & \begin{tabular}{|l|} 
Not \\
required
\end{tabular} & \begin{tabular}{|l|} 
Not \\
required
\end{tabular} & \begin{tabular}{|l|} 
Not \\
required
\end{tabular} \\
\hline Trichloroethene & $\mu \mathrm{g} / \mathrm{L}$ & 0.68 & $<0.4$ & 0.51 & 0.48 & $<0.4$ & $\begin{array}{l}\text { Not } \\
\text { required }\end{array}$ & $<0.5$ & 0.7 & $<250$ & $<0.5$ & $<0.5$ & & $<0.5$ & $<0.5$ & $<0.5$ & $<0.5$ \\
\hline \begin{tabular}{|l}
$\begin{array}{l}\text { Trichlorofluoro- } \\
\text { methane }\end{array}$ \\
\end{tabular} & $\mu \mathrm{g} / \mathrm{L}$ & $<0.4$ & $<0.4$ & $<0.4$ & Not required & $<0.4$ & \begin{tabular}{|l|}
$\begin{array}{l}\text { Not } \\
\text { required }\end{array}$ \\
\end{tabular} & \begin{tabular}{|l|}
$\begin{array}{l}\text { Not } \\
\text { required }\end{array}$ \\
\end{tabular} & \begin{tabular}{|l|}
$\begin{array}{l}\text { Not } \\
\text { required }\end{array}$ \\
\end{tabular} & \begin{tabular}{|l|}
$\begin{array}{l}\text { Not } \\
\text { required }\end{array}$ \\
\end{tabular} & \begin{tabular}{|l|}
$\begin{array}{l}\text { Not } \\
\text { required }\end{array}$ \\
\end{tabular} & \begin{tabular}{|l|}
$\begin{array}{l}\text { Not } \\
\text { required }\end{array}$ \\
\end{tabular} & & \begin{tabular}{|l}
$\begin{array}{l}\text { Not } \\
\text { required }\end{array}$ \\
\end{tabular} & \begin{tabular}{|l|}
$\begin{array}{l}\text { Not } \\
\text { required }\end{array}$ \\
\end{tabular} & \begin{tabular}{|l|}
$\begin{array}{l}\text { Not } \\
\text { required }\end{array}$ \\
\end{tabular} & \begin{tabular}{|l|l}
$\begin{array}{l}\text { Not } \\
\text { required }\end{array}$ \\
\end{tabular} \\
\hline Tri -n-Butylphosphate & $\mu \mathrm{g} / \mathrm{L}$ & & & & & & & & & & & & & $<7$ & $<0.7$ & $<0.7$ & $<0.7$ \\
\hline $\begin{array}{l}\text { Tris(2-Chloroethyl) } \\
\text { Phosphate }\end{array}$ & $\mu \mathrm{g} / \mathrm{L}$ & & & & & & & & & & & & & $<15$ & $<1.5$ & $<1.5$ & $<1.5$ \\
\hline Vinyl Acetate & $\mu \mathrm{g} / \mathrm{L}$ & $\begin{array}{l}\text { Not } \\
\text { required }\end{array}$ & \begin{tabular}{|l} 
Not \\
required
\end{tabular} & $<2$ & Not required & $\begin{array}{l}\text { Not } \\
\text { required }\end{array}$ & $\begin{array}{l}\text { Not } \\
\text { required }\end{array}$ & $\begin{array}{l}\text { Not } \\
\text { required }\end{array}$ & $\begin{array}{l}\text { Not } \\
\text { required }\end{array}$ & \begin{tabular}{|l} 
Not \\
required
\end{tabular} & $\begin{array}{l}\text { Not } \\
\text { required }\end{array}$ & \begin{tabular}{|l} 
Not \\
required
\end{tabular} & & \begin{tabular}{|l} 
Not \\
required
\end{tabular} & $\begin{array}{l}\text { Not } \\
\text { required }\end{array}$ & \begin{tabular}{|l} 
Not \\
required
\end{tabular} & $\begin{array}{l}\text { Not } \\
\text { required }\end{array}$ \\
\hline Vinyl Chloride & $\mu \mathrm{g} / \mathrm{L}$ & $<0.4$ & $<0.4$ & $<0.4$ & Not required & $<0.4$ & $<0.6$ & $<0.6$ & $\begin{array}{l}\text { Not } \\
\text { required }\end{array}$ & $\begin{array}{l}\text { Not } \\
\text { required }\end{array}$ & $<0.6$ & $<0.6$ & & $<0.6$ & $<0.6$ & $<0.6$ & $<0.6$ \\
\hline
\end{tabular}




\section{Appendix B}

Range and Average Concentration of Detected Groundwater Monitoring Constituents 
Table B.1. Range and Average Concentration of Detected Groundwater Monitoring Constituents

\begin{tabular}{|c|c|c|c|c|c|c|c|}
\hline Constituent & Well Number & Filtered & Minimum & Maximum & Average & Units & $\begin{array}{c}\text { Number of } \\
\text { Samples } \\
\end{array}$ \\
\hline 1,1,1-Trichloroethane & $699-22-35$ & $\mathrm{~N}$ & 4.1 & 38 & 14.23461538 & $\mu \mathrm{g} / \mathrm{L}$ & 26 \\
\hline 1,1,1-Trichloroethane & 699-23-34A & $\mathrm{N}$ & 2 & 60 & 22.42156863 & $\mu \mathrm{g} / \mathrm{L}$ & 52 \\
\hline 1,1,1-Trichloroethane & 699-23-34B & $\mathrm{N}$ & 1.5 & 30 & 12.77307692 & $\mu \mathrm{g} / \mathrm{L}$ & 26 \\
\hline 1,1,1-Trichloroethane & 699-24-33 & $\mathrm{N}$ & 0 & 26.33333333 & 9.269496855 & $\mu \mathrm{g} / \mathrm{L}$ & 54 \\
\hline 1,1,1-Trichloroethane & 699-24-34A & $\mathrm{N}$ & 3 & 44 & 15.44795918 & $\mu \mathrm{g} / \mathrm{L}$ & 50 \\
\hline 1,1,1-Trichloroethane & 699-24-34B & $\mathrm{N}$ & 2 & 62.5 & 16.419 & $\mu \mathrm{g} / \mathrm{L}$ & 51 \\
\hline 1,1,1-Trichloroethane & 699-24-34C & $\mathrm{N}$ & 0 & 35 & 11.82941176 & $\mu \mathrm{g} / \mathrm{L}$ & 52 \\
\hline 1,1,1-Trichloroethane & 699-24-35 & $\mathrm{N}$ & 0 & 6.8 & 2.680392157 & $\mu \mathrm{g} / \mathrm{L}$ & 52 \\
\hline 1,1,1-Trichloroethane & $699-25-34 \mathrm{C}$ & $\mathrm{N}$ & 0 & 8.1 & 2.989 & $\mu \mathrm{g} / \mathrm{L}$ & 51 \\
\hline 1,1,1-Trichloroethane & 699-26-35A & $\mathrm{N}$ & 0 & 4 & 1.20452381 & $\mu \mathrm{g} / \mathrm{L}$ & 42 \\
\hline 1,1,2-Trichloroethane & 699-23-34A & $\mathrm{N}$ & 0 & 0.06 & 0.0012 & $\mu \mathrm{g} / \mathrm{L}$ & 51 \\
\hline 1,1,2-Trichloroethane & 699-24-34B & $\mathrm{N}$ & 0 & 0.5 & 0.010204082 & $\mu \mathrm{g} / \mathrm{L}$ & 50 \\
\hline 1,1,2-Trichloroethane & 699-24-34C & $\mathrm{N}$ & 0 & 0.6 & 0.012 & $\mu \mathrm{g} / \mathrm{L}$ & 51 \\
\hline 1,1,2-Trichloroethane & 699-24-35 & $\mathrm{N}$ & 0 & 0.28 & 0.0056 & $\mu \mathrm{g} / \mathrm{L}$ & 51 \\
\hline 1,1,2-Trichloroethane & $699-25-34 \mathrm{C}$ & $\mathrm{N}$ & 0 & 0.06 & 0.00122449 & $\mu \mathrm{g} / \mathrm{L}$ & 50 \\
\hline 1,1-Dichloroethane & $699-22-35$ & $\mathrm{~N}$ & 1.2 & 5.5 & 3.480769231 & $\mu \mathrm{g} / \mathrm{L}$ & 26 \\
\hline 1,1-Dichloroethane & 699-23-34A & $\mathrm{N}$ & 0 & 7 & 2.586078431 & $\mu \mathrm{g} / \mathrm{L}$ & 52 \\
\hline 1,1-Dichloroethane & 699-23-34B & $\mathrm{N}$ & 0 & 5.4 & 3.130769231 & $\mu \mathrm{g} / \mathrm{L}$ & 26 \\
\hline 1,1-Dichloroethane & 699-24-33 & $\mathrm{N}$ & 0 & 2.2 & 0.8625 & $\mu \mathrm{g} / \mathrm{L}$ & 51 \\
\hline 1,1-Dichloroethane & 699-24-34A & $\mathrm{N}$ & 0 & 5.1 & 1.701734694 & $\mu \mathrm{g} / \mathrm{L}$ & 50 \\
\hline 1,1-Dichloroethane & 699-24-34B & $\mathrm{N}$ & 0 & 6 & 1.6607 & $\mu \mathrm{g} / \mathrm{L}$ & 51 \\
\hline 1,1-Dichloroethane & 699-24-34C & $\mathrm{N}$ & 0 & 4 & 1.372352941 & $\mu \mathrm{g} / \mathrm{L}$ & 52 \\
\hline 1,1-Dichloroethane & $699-24-35$ & $\mathrm{~N}$ & 0 & 1.4 & 0.135960784 & $\mu \mathrm{g} / \mathrm{L}$ & 52 \\
\hline 1,1-Dichloroethane & 699-25-34C & $\mathrm{N}$ & 0 & 1.4 & 0.173 & $\mu \mathrm{g} / \mathrm{L}$ & 51 \\
\hline 1,1-Dichloroethane & 699-26-35A & $\mathrm{N}$ & 0 & 1.3 & 0.046428571 & $\mu \mathrm{g} / \mathrm{L}$ & 42 \\
\hline 1,2-Dichloroethane & 699-23-34A & $\mathrm{N}$ & 0 & 0.3 & 0.013333333 & $\mu \mathrm{g} / \mathrm{L}$ & 52 \\
\hline 1,2-Dichloroethane & 699-23-34B & $\mathrm{N}$ & 0 & 1 & 0.038461538 & $\mu \mathrm{g} / \mathrm{L}$ & 26 \\
\hline 1,2-Dichloroethane & 699-24-34A & $\mathrm{N}$ & 0 & 0.63 & 0.012857143 & $\mu \mathrm{g} / \mathrm{L}$ & 50 \\
\hline 1,2-Dichloroethane & 699-24-34B & $\mathrm{N}$ & 0 & 0.5 & 0.01 & $\mu \mathrm{g} / \mathrm{L}$ & 51 \\
\hline 1,2-Dichloroethane & 699-24-34C & $\mathrm{N}$ & 0 & 0.5 & 0.009803922 & $\mu \mathrm{g} / \mathrm{L}$ & 52 \\
\hline 1,2-Dichloroethane & 699-24-35 & $\mathrm{N}$ & 0 & 0.5 & 0.01 & $\mu \mathrm{g} / \mathrm{L}$ & 51 \\
\hline 1,2-Dichloroethane & 699-25-34C & $\mathrm{N}$ & 0 & 0.12 & 0.00244898 & $\mu \mathrm{g} / \mathrm{L}$ & 50 \\
\hline 1,2-Dichloroethane & 699-26-35A & $\mathrm{N}$ & 0 & 1 & 0.024390244 & $\mu \mathrm{g} / \mathrm{L}$ & 41 \\
\hline 1,4-Dichlorobenzene & 699-22-35 & $\mathrm{N}$ & 0 & 0.1 & 0.003846154 & $\mu \mathrm{g} / \mathrm{L}$ & 26 \\
\hline 1,4-Dichlorobenzene & 699-23-34A & $\mathrm{N}$ & 0 & 1 & 0.240869565 & $\mu \mathrm{g} / \mathrm{L}$ & 47 \\
\hline 1,4-Dichlorobenzene & 699-23-34B & $\mathrm{N}$ & 0 & 0.87 & 0.117192308 & $\mu \mathrm{g} / \mathrm{L}$ & 26 \\
\hline 1,4-Dichlorobenzene & 699-24-33 & $\mathrm{N}$ & 0 & 0.5 & 0.015468085 & $\mu \mathrm{g} / \mathrm{L}$ & 48 \\
\hline 1,4-Dichlorobenzene & 699-24-34A & $\mathrm{N}$ & 0 & 0.37 & 0.073840909 & $\mu \mathrm{g} / \mathrm{L}$ & 45 \\
\hline 1,4-Dichlorobenzene & 699-24-34B & $\mathrm{N}$ & 0 & 0.43 & 0.085822222 & $\mu \mathrm{g} / \mathrm{L}$ & 46 \\
\hline 1,4-Dichlorobenzene & 699-24-34C & $\mathrm{N}$ & 0 & 0.38 & 0.009347826 & $\mu \mathrm{g} / \mathrm{L}$ & 47 \\
\hline 1,4-Dichlorobenzene & 699-24-35 & $\mathrm{N}$ & 0 & 0.055 & 0.001195652 & $\mu \mathrm{g} / \mathrm{L}$ & 47 \\
\hline 1,4-Dichlorobenzene & 699-26-35A & $\mathrm{N}$ & 0 & 0.05 & 0.001315789 & $\mu \mathrm{g} / \mathrm{L}$ & 38 \\
\hline
\end{tabular}




\begin{tabular}{|c|c|c|c|c|c|c|c|}
\hline Constituent & Well Number & Filtered & Minimum & Maximum & Average & Units & $\begin{array}{c}\text { Number of } \\
\text { Samples }\end{array}$ \\
\hline 1-(o-Chlorophenyl)thiourea & 699-23-34A & $\mathrm{N}$ & 200 & 200 & 200 & $\mu \mathrm{g} / \mathrm{L}$ & 1 \\
\hline 1-(o-Chlorophenyl)thiourea & $699-24-34 \mathrm{~A}$ & $\mathrm{~N}$ & 200 & 200 & 200 & $\mu \mathrm{g} / \mathrm{L}$ & 1 \\
\hline 1-(o-Chlorophenyl)thiourea & 699-24-34B & $\mathrm{N}$ & 200 & 200 & 200 & $\mu \mathrm{g} / \mathrm{L}$ & 1 \\
\hline 1-(o-Chlorophenyl)thiourea & $699-24-34 \mathrm{C}$ & $\mathrm{N}$ & 200 & 200 & 200 & $\mu \mathrm{g} / \mathrm{L}$ & 1 \\
\hline 1-(o-Chlorophenyl)thiourea & $699-24-35$ & $\mathrm{~N}$ & 200 & 200 & 200 & $\mu \mathrm{g} / \mathrm{L}$ & 1 \\
\hline 1-(o-Chlorophenyl)thiourea & $699-25-34 \mathrm{C}$ & $\mathrm{N}$ & 200 & 200 & 200 & $\mu \mathrm{g} / \mathrm{L}$ & 1 \\
\hline 1-(o-Chlorophenyl)thiourea & $699-26-35 \mathrm{~A}$ & $\mathrm{~N}$ & 200 & 200 & 200 & $\mu \mathrm{g} / \mathrm{L}$ & 1 \\
\hline 1-Acetyl-2-thiourea & $699-23-34 \mathrm{~A}$ & $\mathrm{~N}$ & 200 & 200 & 200 & $\mu \mathrm{g} / \mathrm{L}$ & 1 \\
\hline 1-Acetyl-2-thiourea & $699-24-34 \mathrm{~A}$ & $\mathrm{~N}$ & 200 & 200 & 200 & $\mu \mathrm{g} / \mathrm{L}$ & 1 \\
\hline 1-Acetyl-2-thiourea & $699-24-34 \mathrm{~B}$ & $\mathrm{~N}$ & 200 & 200 & 200 & $\mu \mathrm{g} / \mathrm{L}$ & 1 \\
\hline 1-Acetyl-2-thiourea & $699-24-34 \mathrm{C}$ & $\mathrm{N}$ & 200 & 200 & 200 & $\mu \mathrm{g} / \mathrm{L}$ & 1 \\
\hline 1-Acetyl-2-thiourea & $699-24-35$ & $\mathrm{~N}$ & 200 & 200 & 200 & $\mu \mathrm{g} / \mathrm{L}$ & 1 \\
\hline 1-Acetyl-2-thiourea & $699-25-34 \mathrm{C}$ & $\mathrm{N}$ & 200 & 200 & 200 & $\mu \mathrm{g} / \mathrm{L}$ & 1 \\
\hline 1-Acetyl-2-thiourea & $699-26-35 \mathrm{~A}$ & $\mathrm{~N}$ & 200 & 200 & 200 & $\mu \mathrm{g} / \mathrm{L}$ & 1 \\
\hline 1-Naphthyl-2-thiourea & $699-23-34 \mathrm{~A}$ & $\mathrm{~N}$ & 200 & 200 & 200 & $\mu \mathrm{g} / \mathrm{L}$ & 1 \\
\hline 1-Naphthyl-2-thiourea & $699-24-34 \mathrm{~A}$ & $\mathrm{~N}$ & 200 & 200 & 200 & $\mu \mathrm{g} / \mathrm{L}$ & 1 \\
\hline 1-Naphthyl-2-thiourea & 699-24-34B & $\mathrm{N}$ & 200 & 200 & 200 & $\mu \mathrm{g} / \mathrm{L}$ & 1 \\
\hline 1-Naphthyl-2-thiourea & $699-24-34 \mathrm{C}$ & $\mathrm{N}$ & 200 & 200 & 200 & $\mu \mathrm{g} / \mathrm{L}$ & 1 \\
\hline 1-Naphthyl-2-thiourea & $699-24-35$ & $\mathrm{~N}$ & 200 & 200 & 200 & $\mu \mathrm{g} / \mathrm{L}$ & 1 \\
\hline 1-Naphthyl-2-thiourea & $699-25-34 \mathrm{C}$ & $\mathrm{N}$ & 200 & 200 & 200 & $\mu \mathrm{g} / \mathrm{L}$ & 1 \\
\hline 1-Naphthyl-2-thiourea & 699-26-35A & $\mathrm{N}$ & 200 & 200 & 200 & $\mu \mathrm{g} / \mathrm{L}$ & 1 \\
\hline Alkalinity & $699-22-35$ & $\mathrm{~N}$ & 288000 & 288000 & 288000 & $\mu \mathrm{g} / \mathrm{L}$ & 1 \\
\hline Alkalinity & $699-23-34 \mathrm{~A}$ & $\mathrm{~N}$ & 239000 & 239000 & 239000 & $\mu \mathrm{g} / \mathrm{L}$ & 1 \\
\hline Alkalinity & $699-23-34 \mathrm{~B}$ & $\mathrm{~N}$ & 302000 & 302000 & 302000 & $\mu \mathrm{g} / \mathrm{L}$ & 1 \\
\hline Alkalinity & $699-24-33$ & $\mathrm{~N}$ & 237000 & 237000 & 237000 & $\mu \mathrm{g} / \mathrm{L}$ & 1 \\
\hline Alkalinity & 699-24-34A & $\mathrm{N}$ & 210000 & 210000 & 210000 & $\mu \mathrm{g} / \mathrm{L}$ & 1 \\
\hline Alkalinity & $699-24-34 \mathrm{~B}$ & $\mathrm{~N}$ & 228000 & 228000 & 228000 & $\mu \mathrm{g} / \mathrm{L}$ & 1 \\
\hline Alkalinity & $699-24-34 \mathrm{C}$ & $\mathrm{N}$ & 261000 & 261000 & 261000 & $\mu \mathrm{g} / \mathrm{L}$ & 1 \\
\hline Alka linity & $699-25-34 \mathrm{C}$ & $\mathrm{N}$ & 187000 & 187000 & 187000 & $\mu \mathrm{g} / \mathrm{L}$ & 1 \\
\hline Alkalinity & $699-26-35 \mathrm{~A}$ & $\mathrm{~N}$ & 163000 & 163000 & 163000 & $\mu \mathrm{g} / \mathrm{L}$ & 1 \\
\hline Alpha & 699-23-34A & $\mathrm{N}$ & 1.3 & 3.73 & 2.695 & $\mathrm{pCi} / \mathrm{L}$ & 4 \\
\hline Alpha & $699-24-33$ & $\mathrm{~N}$ & 1.08 & 4.62 & 2.729166667 & $\mathrm{pCi} / \mathrm{L}$ & 6 \\
\hline Alpha & $699-24-34 \mathrm{~A}$ & $\mathrm{~N}$ & 2.4 & 4.38 & 3.755 & $\mathrm{pCi} / \mathrm{L}$ & 4 \\
\hline Alpha & 699-24-34B & $\mathrm{N}$ & 1.93 & 5.05 & 2.9025 & $\mathrm{pCi} / \mathrm{L}$ & 4 \\
\hline Alpha & $699-24-34 \mathrm{C}$ & $\mathrm{N}$ & 2.62 & 3.88 & 3.108333333 & $\mathrm{pCi} / \mathrm{L}$ & 3 \\
\hline Alpha & 699-24-35 & $\mathrm{N}$ & 2.62 & 4.57 & 4.04375 & $\mathrm{pCi} / \mathrm{L}$ & 4 \\
\hline Alpha & $699-25-34 \mathrm{C}$ & $\mathrm{N}$ & 2.44 & 4.25 & 3.3375 & $\mathrm{pCi} / \mathrm{L}$ & 4 \\
\hline Alpha & 699-26-35A & $\mathrm{N}$ & 2.13 & 2.13 & 2.13 & $\mathrm{pCi} / \mathrm{L}$ & 1 \\
\hline Aluminum & $699-22-35$ & $\mathrm{Y}$ & 0 & 239 & 22.75 & $\mu \mathrm{g} / \mathrm{L}$ & 26 \\
\hline Aluminum & $699-23-34 \mathrm{~A}$ & $\mathrm{Y}$ & 0 & 52.8 & 4.930232558 & $\mu \mathrm{g} / \mathrm{L}$ & 43 \\
\hline Aluminum & 699-23-34B & $\mathrm{Y}$ & 0 & 74.6 & 6.25 & $\mu \mathrm{g} / \mathrm{L}$ & 26 \\
\hline Aluminum & 699-24-33 & $\mathrm{Y}$ & 0 & 75 & 5.243902439 & $\mu \mathrm{g} / \mathrm{L}$ & 41 \\
\hline Aluminum & $699-24-34 \mathrm{~A}$ & Y & 0 & 128 & 10.81463415 & $\mu \mathrm{g} / \mathrm{L}$ & 41 \\
\hline Aluminum & 699-24-34B & $\mathrm{Y}$ & 0 & 413 & 18.20232558 & $\mu \mathrm{g} / \mathrm{L}$ & 43 \\
\hline Aluminum & $699-24-34 \mathrm{C}$ & Y & 0 & 92.7 & 5.206818182 & $\mu \mathrm{g} / \mathrm{L}$ & 44 \\
\hline
\end{tabular}

B. 2 


\begin{tabular}{|c|c|c|c|c|c|c|c|}
\hline Constituent & Well Number & Filtered & Minimum & Maximum & Average & Units & \begin{tabular}{|c|} 
Number of \\
Samples \\
\end{tabular} \\
\hline Aluminum & \begin{tabular}{|l|}
$699-24-35$ \\
\end{tabular} & $\mathrm{Y}$ & 0 & 80 & 5.786363636 & $\mu \mathrm{g} / \mathrm{L}$ & 44 \\
\hline Aluminum & 699-25-34C & $\mathrm{Y}$ & 0 & 60.2 & 4.193023256 & $\mu \mathrm{g} / \mathrm{L}$ & 43 \\
\hline Aluminum & 699-26-35A & $\mathrm{N}$ & 0 & 522 & 52.2 & $\mu \mathrm{g} / \mathrm{L}$ & 10 \\
\hline Aluminum & 699-26-35A & $\mathrm{Y}$ & 0 & 53.3 & 5.741666667 & $\mu \mathrm{g} / \mathrm{L}$ & 36 \\
\hline Ammonia & 699-24-33 & $\mathrm{N}$ & 0 & 28 & 1.75 & $\mu \mathrm{g} / \mathrm{L}$ & 16 \\
\hline A mmonia & $699-25-34 \mathrm{C}$ & $\mathrm{N}$ & 0 & 68 & 4.25 & $\mu \mathrm{g} / \mathrm{L}$ & 16 \\
\hline Ammonium ion & 699-22-35 & $\mathrm{N}$ & 0 & 30 & 4.5 & $\mu \mathrm{g} / \mathrm{L}$ & 10 \\
\hline Ammonium ion & 699-23-34A & $\mathrm{N}$ & 0 & 100 & 16.78787879 & $\mu \mathrm{g} / \mathrm{L}$ & 33 \\
\hline Ammonium ion & 699-23-34B & $\mathrm{N}$ & 0 & 60 & 15 & $\mu \mathrm{g} / \mathrm{L}$ & 10 \\
\hline Ammonium ion & 699-24-33 & $\mathrm{N}$ & 0 & 156.6666667 & 13.83838384 & $\mu \mathrm{g} / \mathrm{L}$ & 33 \\
\hline Ammonium ion & 699-24-34A & $\mathrm{N}$ & 0 & 100 & 12.29032258 & $\mu \mathrm{g} / \mathrm{L}$ & 31 \\
\hline Ammonium ion & 699-24-34B & $\mathrm{N}$ & 0 & 100 & 10.75757576 & $\mu \mathrm{g} / \mathrm{L}$ & 33 \\
\hline Ammonium ion & 699-24-34C & $\mathrm{N}$ & 0 & 100 & 12.90909091 & $\mu \mathrm{g} / \mathrm{L}$ & 33 \\
\hline Ammonium ion & 699-24-35 & $\mathrm{N}$ & 0 & 100 & 14.45454545 & $\mu \mathrm{g} / \mathrm{L}$ & 33 \\
\hline Ammonium ion & 699-25-34C & $\mathrm{N}$ & 0 & 100 & 13.33333333 & $\mu \mathrm{g} / \mathrm{L}$ & 33 \\
\hline Ammonium ion & 699-26-35A & $\mathrm{N}$ & 0 & 100 & 20.47619048 & $\mu \mathrm{g} / \mathrm{L}$ & 21 \\
\hline Antimony & 699-23-34B & $\mathrm{Y}$ & 0 & 40 & 4.073076923 & $\mu \mathrm{g} / \mathrm{L}$ & 26 \\
\hline Antimony & 699-24-33 & $\mathrm{Y}$ & 0 & 900 & 19.56521739 & $\mu \mathrm{g} / \mathrm{L}$ & 46 \\
\hline Antimony & 699-24-34B & $\mathrm{Y}$ & 0 & 31.4 & 0.682608696 & $\mu \mathrm{g} / \mathrm{L}$ & 46 \\
\hline Antimony & 699-24-35 & $\mathrm{Y}$ & 0 & 17.5 & 0.372340426 & $\mu \mathrm{g} / \mathrm{L}$ & 47 \\
\hline Antimony & 699-25-34C & $\mathrm{Y}$ & 0 & 46 & 1 & $\mu \mathrm{g} / \mathrm{L}$ & 46 \\
\hline Antimony & 699-26-35A & $\mathrm{Y}$ & 0 & 35 & 0.897435897 & $\mu \mathrm{g} / \mathrm{L}$ & 39 \\
\hline Antimony-125 & 699-24-33 & $\mathrm{N}$ & -11 & 13.60000038 & 3.648888932 & $\mathrm{pCi} / \mathrm{L}$ & 9 \\
\hline Arsenic & 699-24-34A & $\mathrm{N}$ & 0 & 5 & 0.454545455 & $\mu \mathrm{g} / \mathrm{L}$ & 11 \\
\hline Arsenic & 699-24-34B & $\mathrm{N}$ & 0 & 6 & 1.090909091 & $\mu \mathrm{g} / \mathrm{L}$ & 11 \\
\hline Arsenic & 699-24-35 & $\mathrm{N}$ & 0 & 7 & 2.272727273 & $\mu \mathrm{g} / \mathrm{L}$ & 11 \\
\hline Arsenic & 699-25-34C & $\mathrm{N}$ & 0 & 22 & 3.2 & $\mu \mathrm{g} / \mathrm{L}$ & 10 \\
\hline Arsenic & 699-26-35A & $\mathrm{N}$ & 0 & 5.2 & 1.381818182 & $\mu \mathrm{g} / \mathrm{L}$ & 11 \\
\hline Arsenic & 699-26-35A & $\mathrm{Y}$ & 0 & 6.3 & 3.15 & $\mu \mathrm{g} / \mathrm{L}$ & 2 \\
\hline Arsenic, filtered & 699-24-33 & $\mathrm{N}$ & 0 & 5 & 0.416666667 & $\mu \mathrm{g} / \mathrm{L}$ & 12 \\
\hline Arsenic, filtered & 699-24-35 & $\mathrm{N}$ & 0 & 6 & 1.909090909 & $\mu \mathrm{g} / \mathrm{L}$ & 11 \\
\hline Arsenic, filtered & 699-25-34C & $\mathrm{N}$ & 0 & 6 & 1.1 & $\mu \mathrm{g} / \mathrm{L}$ & 10 \\
\hline Arsenic, filtered & 699-26-35A & $\mathrm{N}$ & 0 & 5 & 0.833333333 & $\mu \mathrm{g} / \mathrm{L}$ & 6 \\
\hline Barium & 699-22-35 & $\mathrm{Y}$ & 97 & 152 & 129.1153846 & $\mu \mathrm{g} / \mathrm{L}$ & 26 \\
\hline Barium & 699-23-34A & $\mathrm{N}$ & 70.9 & 84 & 77.46470588 & $\mu \mathrm{g} / \mathrm{L}$ & 17 \\
\hline Barium & 699-23-34A & $\mathrm{Y}$ & 68 & 150 & 91.05208333 & $\mu \mathrm{g} / \mathrm{L}$ & 48 \\
\hline Barium & 699-23-34B & $\mathrm{Y}$ & 52.8 & 143 & 121.2038462 & $\mu \mathrm{g} / \mathrm{L}$ & 26 \\
\hline Barium & $699-24-33$ & $\mathrm{~N}$ & 47.33333333 & 63.6 & 58.1037037 & $\mu \mathrm{g} / \mathrm{L}$ & 9 \\
\hline Barium & 699-24-33 & $\mathrm{Y}$ & 53 & 114 & 74.35217391 & $\mu \mathrm{g} / \mathrm{L}$ & 46 \\
\hline Barium & 699-24-34A & $\mathrm{N}$ & 57 & 69 & 63.33333333 & $\mu \mathrm{g} / \mathrm{L}$ & 15 \\
\hline Barium & 699-24-34A & $\mathrm{Y}$ & 58 & 121 & 75.42391304 & $\mu \mathrm{g} / \mathrm{L}$ & 46 \\
\hline Barium & 699-24-34B & $\mathrm{N}$ & 61.4 & 82 & 67.8375 & $\mu \mathrm{g} / \mathrm{L}$ & 16 \\
\hline Barium & 699-24-34B & $\mathrm{Y}$ & 60 & 131 & 77.79791667 & $\mu \mathrm{g} / \mathrm{L}$ & 48 \\
\hline Barium & 699-24-34C & $\mathrm{N}$ & 46 & 61 & 51.10588235 & $\mu \mathrm{g} / \mathrm{L}$ & 17 \\
\hline
\end{tabular}




\begin{tabular}{|c|c|c|c|c|c|c|c|}
\hline Constituent & Well Number & Filtered & Minimum & Maximum & Average & Units & \begin{tabular}{|c|} 
Number of \\
Samples \\
\end{tabular} \\
\hline Barium & 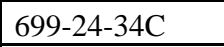 & $\mathrm{Y}$ & 46 & 104 & 61.91020408 & $\mu \mathrm{g} / \mathrm{L}$ & 49 \\
\hline Barium & 699-24-35 & $\mathrm{N}$ & 42 & 60 & 47.52941176 & $\mu \mathrm{g} / \mathrm{L}$ & 17 \\
\hline Barium & 699-24-35 & $\mathrm{Y}$ & 41 & 2800 & 113.7755102 & $\mu \mathrm{g} / \mathrm{L}$ & 49 \\
\hline Barium & 699-25-34C & $\mathrm{N}$ & 33 & 45 & 39.5625 & $\mu \mathrm{g} / \mathrm{L}$ & 16 \\
\hline Barium & 699-25-34C & $\mathrm{Y}$ & 33 & 75.4 & 52.11041667 & $\mu \mathrm{g} / \mathrm{L}$ & 48 \\
\hline Barium & 699-26-35A & $\mathrm{N}$ & 28 & 44 & 33.75 & $\mu \mathrm{g} / \mathrm{L}$ & 14 \\
\hline Barium & 699-26-35A & $\mathrm{Y}$ & 29 & 55.3 & 39.61707317 & $\mu \mathrm{g} / \mathrm{L}$ & 41 \\
\hline Benzene & 699-22-35 & $\mathrm{N}$ & 0 & 0.54 & 0.029 & $\mu \mathrm{g} / \mathrm{L}$ & 25 \\
\hline Benzene & 699-23-34A & $\mathrm{N}$ & 0 & 0.17 & 0.003777778 & $\mu \mathrm{g} / \mathrm{L}$ & 45 \\
\hline Benzene & 699-23-34B & $\mathrm{N}$ & 0 & 0.09 & 0.0052 & $\mu \mathrm{g} / \mathrm{L}$ & 25 \\
\hline Benzene & $699-24-34 \mathrm{C}$ & $\mathrm{N}$ & 0 & 0.21 & 0.004666667 & $\mu \mathrm{g} / \mathrm{L}$ & 45 \\
\hline Benzene & 699-26-35A & $\mathrm{N}$ & 0 & 0.4 & 0.01 & $\mu \mathrm{g} / \mathrm{L}$ & 40 \\
\hline Beryllium & $699-22-35$ & $\mathrm{Y}$ & 0 & 0.61 & 0.181153846 & $\mu \mathrm{g} / \mathrm{L}$ & 26 \\
\hline Beryllium & 699-23-34A & $\mathrm{Y}$ & 0 & 0.71 & 0.076956522 & $\mu \mathrm{g} / \mathrm{L}$ & 46 \\
\hline Bery llium & 699-23-34B & $\mathrm{Y}$ & 0 & 0.8 & 0.189230769 & $\mu \mathrm{g} / \mathrm{L}$ & 26 \\
\hline Beryllium & 699-24-33 & $\mathrm{Y}$ & 0 & 0.91 & 0.066195652 & $\mu \mathrm{g} / \mathrm{L}$ & 46 \\
\hline Beryllium & 699-24-34A & $\mathrm{Y}$ & 0 & 0.79 & 0.059090909 & $\mu \mathrm{g} / \mathrm{L}$ & 44 \\
\hline Beryllium & 699-24-34B & $\mathrm{Y}$ & 0 & 0.74 & 0.044565217 & $\mu \mathrm{g} / \mathrm{L}$ & 46 \\
\hline Beryllium & 699-24-34C & $\mathrm{Y}$ & 0 & 6 & 0.234468085 & $\mu \mathrm{g} / \mathrm{L}$ & 47 \\
\hline Beryllium & 699-24-35 & $\mathrm{Y}$ & 0 & 7 & 0.303617021 & $\mu \mathrm{g} / \mathrm{L}$ & 47 \\
\hline Beryllium & 699-25-34C & $\mathrm{Y}$ & 0 & 0.73 & 0.077826087 & $\mu \mathrm{g} / \mathrm{L}$ & 46 \\
\hline Beryllium & 699-26-35A & $\mathrm{Y}$ & 0 & 0.84 & 0.149487179 & $\mu \mathrm{g} / \mathrm{L}$ & 39 \\
\hline Beryllium-7 & 699-24-33 & $\mathrm{N}$ & -154 & 10.5 & -43.55000019 & $\mathrm{pCi} / \mathrm{L}$ & 4 \\
\hline Boron & 699-23-34A & $\mathrm{N}$ & 30 & 98 & 42.21428571 & $\mu \mathrm{g} / \mathrm{L}$ & 7 \\
\hline Boron & 699-23-34A & $\mathrm{Y}$ & 26 & 40 & 33.16666667 & $\mu \mathrm{g} / \mathrm{L}$ & 6 \\
\hline Boron & 699-24-33 & $\mathrm{N}$ & 36 & 57 & 44.5 & $\mu \mathrm{g} / \mathrm{L}$ & 5 \\
\hline Boron & 699-24-33 & $\mathrm{Y}$ & 39.5 & 51 & 44.9 & $\mu \mathrm{g} / \mathrm{L}$ & 5 \\
\hline Boron & 699-24-34A & $\mathrm{N}$ & 35 & 164.5 & 65.3 & $\mu \mathrm{g} / \mathrm{L}$ & 5 \\
\hline Boron & 699-24-34A & $\mathrm{Y}$ & 38 & 68.5 & 46.625 & $\mu \mathrm{g} / \mathrm{L}$ & 4 \\
\hline Boron & 699-24-34B & $\mathrm{N}$ & 32 & 65 & 45.25 & $\mu \mathrm{g} / \mathrm{L}$ & 6 \\
\hline Boron & 699-24-34B & $\mathrm{Y}$ & 34 & 46 & 38.83333333 & $\mu \mathrm{g} / \mathrm{L}$ & 6 \\
\hline Boron & 699-24-34C & $\mathrm{N}$ & 31 & 49 & 39.92857143 & $\mu \mathrm{g} / \mathrm{L}$ & 7 \\
\hline Boron & $699-24-34 \mathrm{C}$ & $\mathrm{Y}$ & 36 & 46 & 39.5 & $\mu \mathrm{g} / \mathrm{L}$ & 7 \\
\hline Boron & 699-24-35 & $\mathrm{N}$ & 28 & 138 & 47.71428571 & $\mu \mathrm{g} / \mathrm{L}$ & 7 \\
\hline Boron & 699-24-35 & $\mathrm{Y}$ & 25 & 88 & 39.85714286 & $\mu \mathrm{g} / \mathrm{L}$ & 7 \\
\hline Boron & $699-25-34 \mathrm{C}$ & $\mathrm{N}$ & 29 & 71 & 42.42857143 & $\mu \mathrm{g} / \mathrm{L}$ & 7 \\
\hline Boron & $699-25-34 \mathrm{C}$ & $\mathrm{Y}$ & 28 & 44 & 35.57142857 & $\mu \mathrm{g} / \mathrm{L}$ & 7 \\
\hline Boron & 699-26-35A & $\mathrm{N}$ & 29 & 29 & 29 & $\mu \mathrm{g} / \mathrm{L}$ & 1 \\
\hline Boron & 699-26-35A & $\mathrm{Y}$ & 42 & 42 & 42 & $\mu \mathrm{g} / \mathrm{L}$ & 1 \\
\hline Bromide & 699-22-35 & $\mathrm{N}$ & 0 & 60 & 18.21428571 & $\mu \mathrm{g} / \mathrm{L}$ & 14 \\
\hline Bromide & 699-23-34A & $\mathrm{N}$ & 0 & 100 & 14.2 & $\mu \mathrm{g} / \mathrm{L}$ & 35 \\
\hline Bromide & 699-23-34B & $\mathrm{N}$ & 0 & 100 & 22.92857143 & $\mu \mathrm{g} / \mathrm{L}$ & 14 \\
\hline Bromide & 699-24-33 & $\mathrm{N}$ & 0 & 99 & 14.61764706 & $\mu \mathrm{g} / \mathrm{L}$ & 34 \\
\hline Bromide & 699-24-34A & $\mathrm{N}$ & 0 & 200 & 17.96969697 & $\mu \mathrm{g} / \mathrm{L}$ & 33 \\
\hline
\end{tabular}




\begin{tabular}{|c|c|c|c|c|c|c|c|}
\hline Constituent & Well Number & Filtered & Minimum & Maximum & Average & Units & \begin{tabular}{|c|} 
Number of \\
Samples \\
\end{tabular} \\
\hline Bromide & 699-24-34B & $\mathrm{N}$ & 0 & 101 & 16.94117647 & $\mu \mathrm{g} / \mathrm{L}$ & 34 \\
\hline Bromide & 699-24-34C & $\mathrm{N}$ & 0 & 95 & 11.08571429 & $\mu \mathrm{g} / \mathrm{L}$ & 35 \\
\hline Bromide & 699-24-35 & $\mathrm{N}$ & 0 & 106 & 13.05714286 & $\mu \mathrm{g} / \mathrm{L}$ & 35 \\
\hline Bromide & 699-25-34C & $\mathrm{N}$ & 0 & 100 & 8.257142857 & $\mu \mathrm{g} / \mathrm{L}$ & 35 \\
\hline Bromide & 699-26-35A & $\mathrm{N}$ & 0 & 99 & 8.586206897 & $\mu \mathrm{g} / \mathrm{L}$ & 29 \\
\hline Cadmium & 699-22-35 & $\mathrm{Y}$ & 0 & 3.2 & 0.288461538 & $\mu \mathrm{g} / \mathrm{L}$ & 26 \\
\hline Cadmium & 699-23-34A & $\mathrm{N}$ & 0 & 2 & 0.117647059 & $\mu \mathrm{g} / \mathrm{L}$ & 17 \\
\hline Cadmium & 699-23-34A & $\mathrm{Y}$ & 0 & 2 & 0.104166667 & $\mu \mathrm{g} / \mathrm{L}$ & 48 \\
\hline Cadmium & 699-23-34B & $\mathrm{Y}$ & 0 & 3.4 & 0.192307692 & $\mu \mathrm{g} / \mathrm{L}$ & 26 \\
\hline Cadmium & 699-24-34A & $\mathrm{N}$ & 0 & 3.65 & 0.376666667 & $\mu \mathrm{g} / \mathrm{L}$ & 15 \\
\hline Cadmium & 699-24-34A & $\mathrm{Y}$ & 0 & 3 & 0.108695652 & $\mu \mathrm{g} / \mathrm{L}$ & 46 \\
\hline Cadmium & 699-24-34B & $\mathrm{N}$ & 0 & 3 & 0.3125 & $\mu \mathrm{g} / \mathrm{L}$ & 16 \\
\hline Cadmium & 699-24-34C & $\mathrm{N}$ & 0 & 2 & 0.117647059 & $\mu \mathrm{g} / \mathrm{L}$ & 17 \\
\hline Cadmium & 699-24-34C & $\mathrm{Y}$ & 0 & 2.2 & 0.07755102 & $\mu \mathrm{g} / \mathrm{L}$ & 49 \\
\hline Cadmium & 699-24-35 & $\mathrm{N}$ & 0 & 3 & 0.411764706 & $\mu \mathrm{g} / \mathrm{L}$ & 17 \\
\hline Cadmium & 699-24-35 & $\mathrm{Y}$ & 0 & 3.7 & 0.173469388 & $\mu \mathrm{g} / \mathrm{L}$ & 49 \\
\hline Cadmium & $699-25-34 \mathrm{C}$ & $\mathrm{N}$ & 0 & 8 & 0.5 & $\mu \mathrm{g} / \mathrm{L}$ & 16 \\
\hline Cadmium & 699-25-34C & $\mathrm{Y}$ & 0 & 4.65 & 0.148958333 & $\mu \mathrm{g} / \mathrm{L}$ & 48 \\
\hline Cadmium & 699-26-35A & $\mathrm{Y}$ & 0 & 2.1 & 0.051219512 & $\mu \mathrm{g} / \mathrm{L}$ & 41 \\
\hline Calcium & 699-22-35 & $\mathrm{Y}$ & 91000 & 129000 & 112057.6923 & $\mu \mathrm{g} / \mathrm{L}$ & 26 \\
\hline Calcium & 699-23-34A & $\mathrm{N}$ & 63900 & 81000 & 73129.41176 & $\mu \mathrm{g} / \mathrm{L}$ & 17 \\
\hline Calcium & 699-23-34A & $\mathrm{Y}$ & 53900 & 104000 & 83048.95833 & $\mu \mathrm{g} / \mathrm{L}$ & 48 \\
\hline Calcium & 699-23-34B & $\mathrm{Y}$ & 63000 & 123000 & 104719.2308 & $\mu \mathrm{g} / \mathrm{L}$ & 26 \\
\hline Calcium & 699-24-33 & $\mathrm{N}$ & 63300 & 75000 & 68175 & $\mu \mathrm{g} / \mathrm{L}$ & 8 \\
\hline Calcium & 699-24-33 & $\mathrm{Y}$ & 49300 & 109000 & 81355.43478 & $\mu \mathrm{g} / \mathrm{L}$ & 46 \\
\hline Calcium & 699-24-34A & $\mathrm{N}$ & 52000 & 76500 & 67850 & $\mu \mathrm{g} / \mathrm{L}$ & 15 \\
\hline Calcium & 699-24-34A & $\mathrm{Y}$ & 50800 & 92300 & 75706.52174 & $\mu \mathrm{g} / \mathrm{L}$ & 46 \\
\hline Calcium & 699-24-34B & $\mathrm{N}$ & 58200 & 87800 & 71975 & $\mu \mathrm{g} / \mathrm{L}$ & 16 \\
\hline Calcium & 699-24-34B & $\mathrm{Y}$ & 55700 & 99400 & 78765.625 & $\mu \mathrm{g} / \mathrm{L}$ & 48 \\
\hline Calcium & 699-24-34C & $\mathrm{N}$ & 55400 & 88000 & 69302.94118 & $\mu \mathrm{g} / \mathrm{L}$ & 17 \\
\hline Calcium & 699-24-34C & $\mathrm{Y}$ & 51200 & 110000 & 85993.87755 & $\mu \mathrm{g} / \mathrm{L}$ & 49 \\
\hline Calcium & 699-24-35 & $\mathrm{N}$ & 37800 & 63100 & 46370.58824 & $\mu \mathrm{g} / \mathrm{L}$ & 17 \\
\hline Calcium & 699-24-35 & $\mathrm{Y}$ & 34100 & 290000 & 62729.59184 & $\mu \mathrm{g} / \mathrm{L}$ & 49 \\
\hline Calcium & 699-25-34C & $\mathrm{N}$ & 35900 & 56000 & 44500 & $\mu \mathrm{g} / \mathrm{L}$ & 16 \\
\hline Calcium & $699-25-34 \mathrm{C}$ & $\mathrm{Y}$ & 31200 & 86400 & 61317.70833 & $\mu \mathrm{g} / \mathrm{L}$ & 48 \\
\hline Calcium & 699-26-35A & $\mathrm{N}$ & 31000 & 46000 & 39757.14286 & $\mu \mathrm{g} / \mathrm{L}$ & 14 \\
\hline Calcium & 699-26-35A & $\mathrm{Y}$ & 30900 & 65600 & 47707.31707 & $\mu \mathrm{g} / \mathrm{L}$ & 41 \\
\hline Carbon tetrachloride & 699-22-35 & $\mathrm{N}$ & 0 & 3.2 & 0.581923077 & $\mu \mathrm{g} / \mathrm{L}$ & 26 \\
\hline Carbon tetrachloride & 699-23-34A & $\mathrm{N}$ & 0 & 7 & 0.146730769 & $\mu \mathrm{g} / \mathrm{L}$ & 53 \\
\hline Carbon tetrachloride & 699-23-34B & $\mathrm{N}$ & 0 & 2.1 & 0.34 & $\mu \mathrm{g} / \mathrm{L}$ & 26 \\
\hline Carbon tetrachloride & 699-24-33 & $\mathrm{N}$ & 0 & 1.6 & 0.087264151 & $\mu \mathrm{g} / \mathrm{L}$ & 54 \\
\hline Carbon tetrachloride & 699-24-34A & $\mathrm{N}$ & 0 & 5 & 0.1274 & $\mu \mathrm{g} / \mathrm{L}$ & 51 \\
\hline Carbon tetrachloride & 699-24-34B & $\mathrm{N}$ & 0 & 9.3 & 0.314901961 & $\mu \mathrm{g} / \mathrm{L}$ & 52 \\
\hline Carbon tetrachloride & 699-24-34C & $\mathrm{N}$ & 0 & 4 & 0.136826923 & $\mu \mathrm{g} / \mathrm{L}$ & 53 \\
\hline
\end{tabular}




\begin{tabular}{|c|c|c|c|c|c|c|c|}
\hline Constituent & Well Number & Filtered & Minimum & Maximum & Average & Units & \begin{tabular}{|c|} 
Number of \\
Samples \\
\end{tabular} \\
\hline Carbon tetrachloride & $699-24-35$ & $\mathrm{~N}$ & 0 & 0.58 & 0.018823529 & $\mu \mathrm{g} / \mathrm{L}$ & 52 \\
\hline Carbon tetrachloride & $699-25-34 \mathrm{C}$ & $\mathrm{N}$ & 0 & 1 & 0.10256 & $\mu \mathrm{g} / \mathrm{L}$ & 51 \\
\hline Carbon tetrachloride & 699-26-35A & $\mathrm{N}$ & 0 & 2 & 0.184285714 & $\mu \mathrm{g} / \mathrm{L}$ & 42 \\
\hline Cerium/Praseodymium-144 & 699-24-33 & $\mathrm{N}$ & 1.480000019 & 14.89999962 & 6.307499886 & $\mathrm{pCi} / \mathrm{L}$ & 4 \\
\hline Cesium-134 & 699-24-33 & $\mathrm{N}$ & -6.110000134 & 2.829999924 & -1.895000041 & $\mathrm{pCi} / \mathrm{L}$ & 4 \\
\hline Cesium-137 & 699-23-34A & $\mathrm{N}$ & -0.331 & 3.6 & 2.2878 & $\mathrm{pCi} / \mathrm{L}$ & 5 \\
\hline Cesium-137 & 699-24-33 & $\mathrm{N}$ & -8.930000305 & 7.510000229 & -0.77515 & $\mathrm{pCi} / \mathrm{L}$ & 20 \\
\hline Cesium-137 & 699-24-34A & $\mathrm{N}$ & -1.14 & 2.86 & 0.2808 & $\mathrm{pCi} / \mathrm{L}$ & 5 \\
\hline Cesium-137 & 699-24-34B & $\mathrm{N}$ & -2.7845 & 8.27 & 1.8811 & $\mathrm{pCi} / \mathrm{L}$ & 5 \\
\hline Cesium-137 & 699-24-34C & $\mathrm{N}$ & -3.72 & 1.66 & -1.032 & $\mathrm{pCi} / \mathrm{L}$ & 5 \\
\hline Cesium-137 & 699-24-35 & $\mathrm{N}$ & -1.42 & 2.63 & 0.5502 & $\mathrm{pCi} / \mathrm{L}$ & 5 \\
\hline Cesium-137 & 699-25-34C & $\mathrm{N}$ & -3.12 & 3.65 & 1.279 & $\mathrm{pCi} / \mathrm{L}$ & 5 \\
\hline Chemical Oxygen Demand & 699-22-35 & $\mathrm{N}$ & 2600 & 33000 & 4576.153846 & $\mu \mathrm{g} / \mathrm{L}$ & 26 \\
\hline Chemical Oxygen Demand & 699-23-34A & $\mathrm{N}$ & 2550 & 19000 & 3558 & $\mu \mathrm{g} / \mathrm{L}$ & 35 \\
\hline Chemical Oxygen Demand & 699-23-34B & $\mathrm{N}$ & 2600 & 25000 & 4117.692308 & $\mu \mathrm{g} / \mathrm{L}$ & 26 \\
\hline Chemical Oxygen Demand & 699-24-33 & $\mathrm{N}$ & 2550 & 34000 & 5388.571429 & $\mu \mathrm{g} / \mathrm{L}$ & 35 \\
\hline Chemical Oxygen Demand & 699-24-34A & $\mathrm{N}$ & 2550 & 26000 & 3988.857143 & $\mu \mathrm{g} / \mathrm{L}$ & 35 \\
\hline Chemical Oxygen Demand & 699-24-34B & $\mathrm{N}$ & 2550 & 25000 & 4046.857143 & $\mu \mathrm{g} / \mathrm{L}$ & 35 \\
\hline Chemical Oxygen Demand & 699-24-34C & $\mathrm{N}$ & 2550 & 24000 & 3931.714286 & $\mu \mathrm{g} / \mathrm{L}$ & 35 \\
\hline Chemical Oxygen Demand & 699-24-35 & $\mathrm{N}$ & 2550 & 41000 & 4246 & $\mu \mathrm{g} / \mathrm{L}$ & 35 \\
\hline Chemical Oxygen Demand & 699-25-34C & $\mathrm{N}$ & 2550 & 50000 & 4531.714286 & $\mu \mathrm{g} / \mathrm{L}$ & 35 \\
\hline Chemical Oxygen Demand & 699-26-35A & $\mathrm{N}$ & 2550 & 38000 & 4274.571429 & $\mu \mathrm{g} / \mathrm{L}$ & 35 \\
\hline Chloride & 699-22-35 & $\mathrm{N}$ & 0 & 7100 & 5876.153846 & $\mu \mathrm{g} / \mathrm{L}$ & 26 \\
\hline Chloride & 699-23-34A & $\mathrm{N}$ & 5270 & 25000 & 7143.333333 & $\mu \mathrm{g} / \mathrm{L}$ & 51 \\
\hline Chloride & 699-23-34B & $\mathrm{N}$ & 5470 & 7700 & 6095.192308 & $\mu \mathrm{g} / \mathrm{L}$ & 26 \\
\hline Chloride & 699-24-33 & $\mathrm{N}$ & 4370 & 9040 & 7199.239766 & $\mu \mathrm{g} / \mathrm{L}$ & 57 \\
\hline Chloride & 699-24-34A & $\mathrm{N}$ & 5300 & 8600 & \begin{tabular}{|l}
6808.163265 \\
\end{tabular} & $\mu \mathrm{g} / \mathrm{L}$ & 49 \\
\hline Chloride & 699-24-34B & $\mathrm{N}$ & 5360 & 8775 & 6968.2 & $\mu \mathrm{g} / \mathrm{L}$ & 50 \\
\hline Chloride & 699-24-34C & $\mathrm{N}$ & 5700 & 9200 & 7251.568627 & $\mu \mathrm{g} / \mathrm{L}$ & 51 \\
\hline Chloride & 699-24-35 & $\mathrm{N}$ & 5200 & 8660 & 6531.764706 & $\mu \mathrm{g} / \mathrm{L}$ & 51 \\
\hline Chloride & 699-25-34C & $\mathrm{N}$ & 6100 & 9120 & 7160.8 & $\mu \mathrm{g} / \mathrm{L}$ & 50 \\
\hline Chloride & 699-26-35A & $\mathrm{N}$ & 6000 & 8620 & 7119.148936 & $\mu \mathrm{g} / \mathrm{L}$ & 47 \\
\hline Chloroform & 699-22-35 & $\mathrm{N}$ & 0 & 4.6 & 1.052307692 & $\mu \mathrm{g} / \mathrm{L}$ & 26 \\
\hline Chloroform & 699-23-34A & $\mathrm{N}$ & 0 & 0.92 & 0.10425 & $\mu \mathrm{g} / \mathrm{L}$ & 53 \\
\hline Chloroform & 699-23-34B & $\mathrm{N}$ & 0 & 1 & 0.379307692 & $\mu \mathrm{g} / \mathrm{L}$ & 26 \\
\hline Chloroform & 699-24-33 & $\mathrm{N}$ & 0 & 0.91 & 0.040365385 & $\mu \mathrm{g} / \mathrm{L}$ & 53 \\
\hline Chloroform & 699-24-34A & $\mathrm{N}$ & 0 & 0.6 & 0.03994 & $\mu \mathrm{g} / \mathrm{L}$ & 51 \\
\hline Chloroform & 699-24-34B & $\mathrm{N}$ & 0 & 0.6 & 0.065627451 & $\mu \mathrm{g} / \mathrm{L}$ & 52 \\
\hline Chloroform & 699-24-34C & $\mathrm{N}$ & 0 & 1.5 & 0.08625 & $\mu \mathrm{g} / \mathrm{L}$ & 53 \\
\hline Chloroform & 699-24-35 & $\mathrm{N}$ & 0 & 0.34 & 0.007647059 & $\mu \mathrm{g} / \mathrm{L}$ & 52 \\
\hline Chloroform & $699-25-34 \mathrm{C}$ & $\mathrm{N}$ & 0 & 0.95 & 0.09202 & $\mu \mathrm{g} / \mathrm{L}$ & 51 \\
\hline Chloroform & 699-26-35A & $\mathrm{N}$ & 0 & 1 & 0.075428571 & $\mu \mathrm{g} / \mathrm{L}$ & 42 \\
\hline Chromium & $699-22-35$ & $\mathrm{Y}$ & 0 & 7.2 & 2.080769231 & $\mu \mathrm{g} / \mathrm{L}$ & 26 \\
\hline Chromium & 699-23-34A & $\mathrm{N}$ & 0 & 17 & 1.647058824 & $\mu \mathrm{g} / \mathrm{L}$ & 17 \\
\hline Chromium & 699-23-34A & $\mathrm{Y}$ & 0 & 13 & 2.527083333 & $\mu \mathrm{g} / \mathrm{L}$ & 48 \\
\hline
\end{tabular}




\begin{tabular}{|c|c|c|c|c|c|c|c|}
\hline Constituent & Well Number & Filtered & Minimum & Maximum & Average & Units & \begin{tabular}{|c|} 
Number of \\
Samples \\
\end{tabular} \\
\hline Chromium & 699-23-34B & $\mathrm{Y}$ & 0 & 19.8 & 2.607692308 & $\mu \mathrm{g} / \mathrm{L}$ & 26 \\
\hline Chromium & 699-24-33 & $\mathrm{N}$ & 0 & 10.33333333 & 1.148148148 & $\mu \mathrm{g} / \mathrm{L}$ & 9 \\
\hline Chromium & $699-24-33$ & $\mathrm{Y}$ & 0 & 14 & 5.215217391 & $\mu \mathrm{g} / \mathrm{L}$ & 46 \\
\hline Chromium & 699-24-34A & $\mathrm{N}$ & 0 & 56 & 7.066666667 & $\mu \mathrm{g} / \mathrm{L}$ & 15 \\
\hline Chromium & 699-24-34A & $\mathrm{Y}$ & 0 & 15 & 3.2 & $\mu \mathrm{g} / \mathrm{L}$ & 46 \\
\hline Chromium & 699-24-34B & $\mathrm{N}$ & 0 & 14 & 2.40625 & $\mu \mathrm{g} / \mathrm{L}$ & 16 \\
\hline Chromium & 699-24-34B & $\mathrm{Y}$ & 0 & 17 & 4.236458333 & $\mu \mathrm{g} / \mathrm{L}$ & 48 \\
\hline Chromium & 699-24-34C & $\mathrm{N}$ & 0 & 37 & 3.470588235 & $\mu \mathrm{g} / \mathrm{L}$ & 17 \\
\hline Chromium & 699-24-34C & \begin{tabular}{|l|}
$Y$ \\
\end{tabular} & 0 & 16 & 6.102040816 & $\mu \mathrm{g} / \mathrm{L}$ & 49 \\
\hline Chromium & 699-24-35 & $\mathrm{N}$ & 0 & 29 & 4.058823529 & $\mu \mathrm{g} / \mathrm{L}$ & 17 \\
\hline Chromium & 699-24-35 & $\mathrm{Y}$ & 0 & 380 & 14.9755102 & $\mu \mathrm{g} / \mathrm{L}$ & 49 \\
\hline Chromium & $699-25-34 \mathrm{C}$ & $\mathrm{N}$ & 0 & 30 & 4.625 & $\mu \mathrm{g} / \mathrm{L}$ & 16 \\
\hline Chromium & $699-25-34 \mathrm{C}$ & $\mathrm{Y}$ & 0 & 93 & 11.60416667 & $\mu \mathrm{g} / \mathrm{L}$ & 48 \\
\hline Chromium & $699-26-35 \mathrm{~A}$ & $\mathrm{~N}$ & 0 & 15 & 1.071428571 & $\mu \mathrm{g} / \mathrm{L}$ & 14 \\
\hline Chromium & 699-26-35A & $\mathrm{Y}$ & 0 & 24 & 13.15121951 & $\mu \mathrm{g} / \mathrm{L}$ & 41 \\
\hline cis -1,2-Dichloroethylene & $699-22-35$ & $\mathrm{~N}$ & 0 & 0.051 & 0.003307692 & $\mu \mathrm{g} / \mathrm{L}$ & 26 \\
\hline cis-1,2-Dichloroethylene & 699-23-34A & $\mathrm{N}$ & 0 & 0.13 & 0.005945946 & & 37 \\
\hline cis-1,2-Dichloroethylene & 699-23-34B & $\mathrm{N}$ & 0 & 0.2 & 0.013846154 & $\mu \mathrm{g} / \mathrm{L}$ & 26 \\
\hline cis -1,2-Dichloroethylene & $699-24-33$ & $\mathrm{~N}$ & 0 & 0.05 & 0.001282051 & & 39 \\
\hline cis -1,2-Dichloroethylene & $699-24-34 \mathrm{~A}$ & $\mathrm{~N}$ & 0 & 1.7 & 0.096486486 & $\mu \mathrm{g} / \mathrm{L}$ & 37 \\
\hline cis -1,2-Dichloroethylene & 699-24-34B & $\mathrm{N}$ & 0 & 0.56 & 0.037189189 & & 37 \\
\hline cis-1,2-Dichloroethylene & 699-24-34C & $\mathrm{N}$ & 0 & 1.3 & 0.060378378 & & 37 \\
\hline cis -1,2-Dichloroethylene & $699-24-35$ & $\mathrm{~N}$ & 0 & 0.27 & 0.013888889 & $\mu \mathrm{g} / \mathrm{L}$ & 36 \\
\hline cis -1,2-Dichloroethylene & $699-25-34 \mathrm{C}$ & $\mathrm{N}$ & 0 & 0.23 & 0.009444444 & $\mu \mathrm{g} / \mathrm{L}$ & 36 \\
\hline Citrus red No. 2 & $699-23-34 \mathrm{~A}$ & $\mathrm{~N}$ & 1000 & 1000 & 1000 & $\mu \mathrm{g} / \mathrm{L}$ & 1 \\
\hline Citrus red No. 2 & 699-24-34A & $\mathrm{N}$ & 1000 & 1000 & 1000 & $\mu \mathrm{g} / \mathrm{L}$ & 1 \\
\hline Citrus red No. 2 & 699-24-34B & $\mathrm{N}$ & 1000 & 1000 & 1000 & $\mu \mathrm{g} / \mathrm{L}$ & 1 \\
\hline Citrus red No. 2 & 699-24-34C & $\mathrm{N}$ & 1000 & 1000 & 1000 & $\mu \mathrm{g} / \mathrm{L}$ & 1 \\
\hline Citrus red No. 2 & 699-24-35 & $\mathrm{N}$ & 1000 & 1000 & 1000 & $\mu \mathrm{g} / \mathrm{L}$ & 1 \\
\hline Citrus red No. 2 & $699-25-34 \mathrm{C}$ & $\mathrm{N}$ & 1000 & 1000 & 1000 & $\mu \mathrm{g} / \mathrm{L}$ & 1 \\
\hline Citrus red No. 2 & 699-26-35A & $\mathrm{N}$ & 1000 & 1000 & 1000 & $\mu \mathrm{g} / \mathrm{L}$ & 1 \\
\hline Cobalt & 699-22-35 & $\mathrm{Y}$ & 0 & 8.2 & 0.315384615 & $\mu \mathrm{g} / \mathrm{L}$ & 26 \\
\hline Cobalt & 699-23-34B & $\mathrm{Y}$ & 0 & 7.5 & 0.423076923 & $\mu \mathrm{g} / \mathrm{L}$ & 26 \\
\hline Cobalt & 699-24-34C & $\mathrm{Y}$ & 0 & 4.9 & 0.119512195 & $\mu \mathrm{g} / \mathrm{L}$ & 41 \\
\hline Cobalt & 699-24-35 & $\mathrm{Y}$ & 0 & 200 & 4.87804878 & $\mu \mathrm{g} / \mathrm{L}$ & 41 \\
\hline Cobalt & $699-25-34 \mathrm{C}$ & $\mathrm{Y}$ & 0 & 11 & 0.363414634 & $\mu \mathrm{g} / \mathrm{L}$ & 41 \\
\hline Cobalt -60 & 699-23-34A & $\mathrm{N}$ & 2.07 & 6.04 & 3.254 & $\mathrm{pCi} / \mathrm{L}$ & 5 \\
\hline Cobalt-60 & $699-24-33$ & $\mathrm{~N}$ & \begin{tabular}{|l|}
-14.1 \\
\end{tabular} & 22 & 2.840958311 & $\mathrm{pCi} / \mathrm{L}$ & 24 \\
\hline Cobalt-60 & 699-24-34A & $\mathrm{N}$ & \begin{tabular}{|l|}
-1.66 \\
\end{tabular} & 4.74 & 1.442 & $\mathrm{pCi} / \mathrm{L}$ & 5 \\
\hline Cobalt-60 & 699-24-34B & $\mathrm{N}$ & 0.977 & 4.8 & 3.3074 & $\mathrm{pCi} / \mathrm{L}$ & 5 \\
\hline Cobalt -60 & 699-24-34C & $\mathrm{N}$ & -3.11 & 4.03 & 0.6258 & $\mathrm{pCi} / \mathrm{L}$ & 5 \\
\hline Cobalt-60 & $699-24-35$ & $\mathrm{~N}$ & -2.76 & 6.48 & 2.2156 & $\mathrm{pCi} / \mathrm{L}$ & 5 \\
\hline Cobalt-60 & 699-25-34C & $\mathrm{N}$ & -3.91 & 1.7 & -0.565 & $\mathrm{pCi} / \mathrm{L}$ & 5 \\
\hline $\begin{array}{l}\text { Coliform (Membrane Filter } \\
\text { Technique) }\end{array}$ & 699-24-34C & $\mathrm{N}$ & 0 & 7 & 1.75 & $\mu \mathrm{g} / \mathrm{L}$ & 4 \\
\hline
\end{tabular}




\begin{tabular}{|c|c|c|c|c|c|c|c|}
\hline Constituent & Well Number & Filtered & Minimum & Maximum & Average & Units & \begin{tabular}{|c|} 
Number of \\
Samples \\
\end{tabular} \\
\hline Coliform Bacteria & $699-22-35$ & $\mathrm{~N}$ & 0 & 1 & 0.291666667 & $\mathrm{Col} / 100 \mathrm{~mL}$ & 24 \\
\hline Coliform Bacteria & 699-23-34A & $\mathrm{N}$ & 0 & 2.2 & 0.895555556 & MPN & 45 \\
\hline Coliform Bacteria & 699-23-34B & $\mathrm{N}$ & 0 & 6 & 0.52 & $\mathrm{Col} / 100 \mathrm{~mL}$ & 25 \\
\hline Coliform Bacteria & 699-24-33 & $\mathrm{N}$ & 0 & 3 & 0.658974359 & MPN & 39 \\
\hline Coliform Bacteria & 699-24-34A & $\mathrm{N}$ & 0 & 2.2 & 1.019148936 & MPN & 47 \\
\hline Coliform Bacteria & 699-24-34B & $\mathrm{N}$ & 0 & 9 & 1.071111111 & MPN & 45 \\
\hline Coliform Bacteria & 699-24-34C & $\mathrm{N}$ & 0 & 2.2 & 0.873913043 & MPN & 46 \\
\hline Coliform Bacteria & 699-24-35 & $\mathrm{N}$ & 0 & 2.2 & 0.94893617 & MPN & 47 \\
\hline Coliform Bacteria & $699-25-34 \mathrm{C}$ & $\mathrm{N}$ & 0 & 5.1 & 0.979545455 & MPN & 45 \\
\hline Coliform Bacteria & 699-26-35A & $\mathrm{N}$ & 0 & 16 & 1.505 & MPN & 40 \\
\hline Copper & 699-22-35 & \begin{tabular}{|l|}
$\mathrm{Y}$ \\
\end{tabular} & 0 & 14 & 0.634615385 & $\mu \mathrm{g} / \mathrm{L}$ & 26 \\
\hline Copper & 699-23-34A & $\mathrm{N}$ & 0 & 6 & 0.352941176 & $\mu \mathrm{g} / \mathrm{L}$ & 17 \\
\hline Copper & $699-23-34 \mathrm{~A}$ & $\mathrm{Y}$ & 0 & 14.1 & 1.002083333 & $\mu \mathrm{g} / \mathrm{L}$ & 48 \\
\hline Copper & 699-23-34B & \begin{tabular}{|l}
$\mathrm{Y}$ \\
\end{tabular} & 0 & 18.7 & 1.961538462 & $\mu \mathrm{g} / \mathrm{L}$ & 26 \\
\hline Copper & 699-24-33 & \begin{tabular}{|l}
$\mathrm{Y}$ \\
\end{tabular} & 0 & 9.9 & 0.910869565 & $\mu \mathrm{g} / \mathrm{L}$ & 46 \\
\hline Copper & 699-24-34A & $\mathrm{N}$ & 0 & 37 & 3.8666666667 & $\mu \mathrm{g} / \mathrm{L}$ & 15 \\
\hline Copper & 699-24-34A & $\mathrm{Y}$ & 0 & 12.2 & 0.460869565 & $\mu \mathrm{g} / \mathrm{L}$ & 46 \\
\hline Copper & 699-24-34B & $\mathrm{N}$ & 0 & 10 & 0.625 & $\mu \mathrm{g} / \mathrm{L}$ & 16 \\
\hline Copper & 699-24-34B & $\mathrm{Y}$ & 0 & 17 & 0.610416667 & $\mu \mathrm{g} / \mathrm{L}$ & 48 \\
\hline Copper & 699-24-34C & $\mathrm{N}$ & 0 & 26 & 1.529411765 & $\mu \mathrm{g} / \mathrm{L}$ & 17 \\
\hline Copper & 699-24-34C & \begin{tabular}{|l|}
$\mathrm{Y}$ \\
\end{tabular} & 0 & 18 & 0.934693878 & $\mu \mathrm{g} / \mathrm{L}$ & 49 \\
\hline Copper & 699-24-35 & $\mathrm{N}$ & 0 & 51 & 4.470588235 & $\mu \mathrm{g} / \mathrm{L}$ & 17 \\
\hline Copper & 699-24-35 & \begin{tabular}{|l|}
$\mathrm{Y}$ \\
\end{tabular} & 0 & 500 & 11.52959184 & $\mu \mathrm{g} / \mathrm{L}$ & 49 \\
\hline Copper & $699-25-34 \mathrm{C}$ & $\mathrm{N}$ & 0 & 42 & 3.375 & $\mu \mathrm{g} / \mathrm{L}$ & 16 \\
\hline Copper & 699-25-34C & \begin{tabular}{|l|}
$\mathrm{Y}$ \\
\end{tabular} & 0 & 16.25 & 0.730208333 & $\mu \mathrm{g} / \mathrm{L}$ & 48 \\
\hline Copper & 699-26-35A & $\mathrm{Y}$ & 0 & 14 & 1.2 & $\mu \mathrm{g} / \mathrm{L}$ & 41 \\
\hline Dibutylphosphate & 699-26-35A & $\mathrm{N}$ & 10000 & 10000 & 10000 & $\mu \mathrm{g} / \mathrm{L}$ & 1 \\
\hline Diethylstilbesterol & 699-23-34A & $\mathrm{N}$ & 200 & 200 & 200 & $\mu \mathrm{g} / \mathrm{L}$ & 1 \\
\hline Diethylstilbesterol & 699-24-34A & $\mathrm{N}$ & 200 & 200 & 200 & $\mu \mathrm{g} / \mathrm{L}$ & 1 \\
\hline Diethylstilbesterol & 699-24-34B & $\mathrm{N}$ & 200 & 200 & 200 & $\mu \mathrm{g} / \mathrm{L}$ & 1 \\
\hline Diethylstilbesterol & $699-24-34 \mathrm{C}$ & $\mathrm{N}$ & 200 & 200 & 200 & $\mu \mathrm{g} / \mathrm{L}$ & 1 \\
\hline Diethylstilbesterol & 699-24-35 & $\mathrm{N}$ & 200 & 200 & 200 & $\mu \mathrm{g} / \mathrm{L}$ & 1 \\
\hline Diethylstilbesterol & $699-25-34 \mathrm{C}$ & $\mathrm{N}$ & 200 & 200 & 200 & $\mu \mathrm{g} / \mathrm{L}$ & 1 \\
\hline Diethylstilbesterol & 699-26-35A & $\mathrm{N}$ & 200 & 200 & 200 & $\mu \mathrm{g} / \mathrm{L}$ & 1 \\
\hline Ethylbenzene & 699-22-35 & $\mathrm{N}$ & 0 & 0.16 & 0.0064 & $\mu \mathrm{g} / \mathrm{L}$ & 25 \\
\hline Ethylbenzene & 699-23-34A & $\mathrm{N}$ & 0 & 0.11 & 0.003055556 & & 36 \\
\hline Ethylbenzene & 699-24-33 & $\mathrm{N}$ & 0 & 5.1 & 0.138421053 & & 38 \\
\hline Ethylbenzene & 699-24-34A & $\mathrm{N}$ & 0 & 0.097 & 0.004361111 & & 36 \\
\hline Ethylbenzene & 699-24-34B & $\mathrm{N}$ & 0 & 0.35 & 0.014916667 & & 36 \\
\hline Ethylbenzene & $699-24-34 \mathrm{C}$ & $\mathrm{N}$ & 0 & 0.12 & 0.003333333 & & 36 \\
\hline Ethylbenzene & 699-24-35 & $\mathrm{N}$ & 0 & 0.14 & 0.004 & $\mu \mathrm{g} / \mathrm{L}$ & 35 \\
\hline Ethylbenzene & $699-25-34 \mathrm{C}$ & $\mathrm{N}$ & 0 & 0.11 & 0.004914286 & $\mu \mathrm{g} / \mathrm{L}$ & 35 \\
\hline Ethylbenzene & 699-26-35A & $\mathrm{N}$ & 0 & 0.1 & 0.004909091 & $\mu \mathrm{g} / \mathrm{L}$ & 33 \\
\hline Ethylene glycol & 699-23-34A & $\mathrm{N}$ & 10000 & 10000 & 10000 & $\mu \mathrm{g} / \mathrm{L}$ & 1 \\
\hline Ethylene glycol & 699-24-34A & $\mathrm{N}$ & 10000 & 10000 & 10000 & $\mu \mathrm{g} / \mathrm{L}$ & 1 \\
\hline
\end{tabular}




\begin{tabular}{|c|c|c|c|c|c|c|c|}
\hline Constituent & Well Number & Filtered & Minimum & Maximum & Average & Units & \begin{tabular}{|c|} 
Number of \\
Samples \\
\end{tabular} \\
\hline Ethylene glycol & 699-24-34B & $\mathrm{N}$ & 10000 & 10000 & 10000 & $\mu \mathrm{g} / \mathrm{L}$ & 1 \\
\hline Ethylene glycol & 699-24-34C & $\mathrm{N}$ & 10000 & 10000 & 10000 & $\mu \mathrm{g} / \mathrm{L}$ & 1 \\
\hline Ethylene glycol & 699-24-35 & $\mathrm{N}$ & 10000 & 10000 & 10000 & $\mu \mathrm{g} / \mathrm{L}$ & 1 \\
\hline Ethylene glycol & 699-25-34C & $\mathrm{N}$ & 10000 & 10000 & 10000 & $\mu \mathrm{g} / \mathrm{L}$ & 1 \\
\hline Ethylenethiourea & 699-23-34A & $\mathrm{N}$ & 200 & 200 & 200 & $\mu \mathrm{g} / \mathrm{L}$ & 1 \\
\hline Ethylenethiourea & 699-24-34A & $\mathrm{N}$ & 200 & 200 & 200 & $\mu \mathrm{g} / \mathrm{L}$ & 1 \\
\hline Ethylenethiourea & 699-24-34B & $\mathrm{N}$ & 200 & 200 & 200 & $\mu \mathrm{g} / \mathrm{L}$ & 1 \\
\hline Ethylenethiourea & 699-24-34C & $\mathrm{N}$ & 200 & 200 & 200 & $\mu \mathrm{g} / \mathrm{L}$ & 1 \\
\hline Ethylenethiourea & 699-24-35 & $\mathrm{N}$ & 200 & 200 & 200 & $\mu \mathrm{g} / \mathrm{L}$ & 1 \\
\hline Ethylenethiourea & 699-25-34C & $\mathrm{N}$ & 200 & 200 & 200 & $\mu \mathrm{g} / \mathrm{L}$ & 1 \\
\hline Ethylenethiourea & 699-26-35A & $\mathrm{N}$ & 200 & 200 & 200 & $\mu \mathrm{g} / \mathrm{L}$ & 1 \\
\hline Europium-154 & 699-24-33 & $\mathrm{N}$ & -1.779999971 & 5.300000191 & 0.900000066 & $\mathrm{pCi} / \mathrm{L}$ & 4 \\
\hline Europium-155 & 699-24-33 & $\mathrm{N}$ & -3.849999905 & 1.429999948 & -0.862749998 & $\mathrm{pCi} / \mathrm{L}$ & 4 \\
\hline Fluoride & 699-22-35 & $\mathrm{N}$ & 0 & 1200 & 478.6730769 & $\mu \mathrm{g} / \mathrm{L}$ & 26 \\
\hline Fluoride & 699-23-34A & $\mathrm{N}$ & 0 & 1400 & 558.4019608 & $\mu \mathrm{g} / \mathrm{L}$ & 51 \\
\hline Fluoride & 699-23-34B & $\mathrm{N}$ & 139 & 1300 & 597.3269231 & $\mu \mathrm{g} / \mathrm{L}$ & 26 \\
\hline Fluoride & 699-24-33 & $\mathrm{N}$ & 0 & 1100 & 517.0628655 & $\mu \mathrm{g} / \mathrm{L}$ & 57 \\
\hline Fluoride & 699-24-34A & $\mathrm{N}$ & 195 & 1300 & 546.5918367 & $\mu \mathrm{g} / \mathrm{L}$ & 49 \\
\hline Fluoride & 699-24-34B & $\mathrm{N}$ & 200 & 1300 & 560.1316667 & $\mu \mathrm{g} / \mathrm{L}$ & 50 \\
\hline Fluoride & 699-24-34C & $\mathrm{N}$ & 202 & 1200 & 552.5343137 & $\mu \mathrm{g} / \mathrm{L}$ & 51 \\
\hline Fluoride & 699-24-35 & $\mathrm{N}$ & 218.5 & 1000 & 494.9803922 & $\mu \mathrm{g} / \mathrm{L}$ & 51 \\
\hline Fluoride & 699-25-34C & $\mathrm{N}$ & 244 & 1000 & 537.44 & $\mu \mathrm{g} / \mathrm{L}$ & 50 \\
\hline Fluoride & 699-26-35A & $\mathrm{N}$ & 0 & 900 & 500.2553191 & $\mu \mathrm{g} / \mathrm{L}$ & 47 \\
\hline Gross alpha & $699-22-35$ & $\mathrm{~N}$ & 2.85 & 12.2 & 5.802307692 & $\mathrm{pCi} / \mathrm{L}$ & 26 \\
\hline Gross alpha & 699-23-34A & $\mathrm{N}$ & 2.147 & 7.48 & 4.379813953 & $\mathrm{pCi} / \mathrm{L}$ & 43 \\
\hline Gross alpha & 699-23-34B & $\mathrm{N}$ & 1.65 & 11.4 & 5.593192308 & $\mathrm{pCi} / \mathrm{L}$ & 26 \\
\hline Gross alpha & 699-24-33 & $\mathrm{N}$ & 1.42 & 7.46 & 3.944535717 & $\mathrm{pCi} / \mathrm{L}$ & 56 \\
\hline Gross alpha & 699-24-34A & $\mathrm{N}$ & 1.68 & 51.6 & 5.456848837 & $\mathrm{pCi} / \mathrm{L}$ & 43 \\
\hline Gross alpha & 699-24-34B & $\mathrm{N}$ & 1.55 & 9.78 & 4.143918605 & $\mathrm{pCi} / \mathrm{L}$ & 43 \\
\hline Gross alpha & 699-24-34C & $\mathrm{N}$ & 2.15 & 7.58 & 4.070627907 & $\mathrm{pCi} / \mathrm{L}$ & 43 \\
\hline Gross alpha & 699-24-35 & $\mathrm{N}$ & 1.16 & 5.52 & 3.773325581 & $\mathrm{pCi} / \mathrm{L}$ & 43 \\
\hline Gross alpha & 699-25-34C & $\mathrm{N}$ & 1.46 & 5.76 & 3.528130952 & $\mathrm{pCi} / \mathrm{L}$ & 42 \\
\hline Gross alpha & 699-26-35A & $\mathrm{N}$ & 1 & 5.53 & 3.188636364 & $\mathrm{pCi} / \mathrm{L}$ & 44 \\
\hline Gross beta & 699-22-35 & $\mathrm{N}$ & 8.904 & 16.1 & 12.42457692 & $\mathrm{pCi} / \mathrm{L}$ & 26 \\
\hline Gross beta & 699-23-34A & $\mathrm{N}$ & 8.699 & 30.4 & 13.81093617 & $\mathrm{pCi} / \mathrm{L}$ & 47 \\
\hline Gross beta & 699-23-34B & $\mathrm{N}$ & 8.75 & 21.2 & 12.52057692 & $\mathrm{pCi} / \mathrm{L}$ & 26 \\
\hline Gross beta & 699-24-33 & $\mathrm{N}$ & 5.555 & 31.25 & 16.3506029 & $\mathrm{pCi} / \mathrm{L}$ & 68 \\
\hline Gross beta & 699-24-34A & $\mathrm{N}$ & 4.27 & 29.1 & 14.25441489 & $\mathrm{pCi} / \mathrm{L}$ & 47 \\
\hline Gross beta & 699-24-34B & $\mathrm{N}$ & 9.89 & 30 & 15.11225532 & $\mathrm{pCi} / \mathrm{L}$ & 47 \\
\hline Gross beta & 699-24-34C & $\mathrm{N}$ & 11.2 & 28.8 & 16.08458696 & $\mathrm{pCi} / \mathrm{L}$ & 46 \\
\hline Gross beta & 699-24-35 & $\mathrm{N}$ & 7.49 & 27.4 & 13.16010638 & $\mathrm{pCi} / \mathrm{L}$ & 47 \\
\hline Gross beta & 699-25-34C & $\mathrm{N}$ & 10.095 & 34 & 16.73930435 & $\mathrm{pCi} / \mathrm{L}$ & 46 \\
\hline Gross beta & 699-26-35A & $\mathrm{N}$ & 8.929 & 35.7 & 16.88015556 & $\mathrm{pCi} / \mathrm{L}$ & 45 \\
\hline Iodine-129 & 699-22-35 & $\mathrm{N}$ & 0.0746 & 0.0746 & 0.0746 & $\mathrm{pCi} / \mathrm{L}$ & 1 \\
\hline Iodine-129 & 699-23-34A & $\mathrm{N}$ & -0.068 & 0.22 & 0.076 & $\mathrm{pCi} / \mathrm{L}$ & 2 \\
\hline
\end{tabular}




\begin{tabular}{|c|c|c|c|c|c|c|c|}
\hline Constituent & Well Number & Filtered & Minimum & Maximum & Average & Units & \begin{tabular}{|c|} 
Number of \\
Samples \\
\end{tabular} \\
\hline Iodine-129 & 699-23-34B & $\mathrm{N}$ & 0.262 & 0.262 & 0.262 & $\mathrm{pCi} / \mathrm{L}$ & 1 \\
\hline Iodine-129 & 699-24-33 & $\mathrm{N}$ & 0.743 & 2.71 & 1.7265 & $\mathrm{pCi} / \mathrm{L}$ & 2 \\
\hline Iodine-129 & 699-26-35A & $\mathrm{N}$ & 1.75 & 2.85 & 2.0625 & $\mathrm{pCi} / \mathrm{L}$ & 4 \\
\hline Iron & 699-22-35 & $\mathrm{Y}$ & 14 & 260 & 55.07115385 & $\mu \mathrm{g} / \mathrm{L}$ & 26 \\
\hline Iron & 699-23-34A & $\mathrm{N}$ & 28 & 816 & 232.7647059 & $\mu \mathrm{g} / \mathrm{L}$ & 17 \\
\hline Iron & 699-23-34A & $\mathrm{Y}$ & 0 & 133 & 46.62083333 & $\mu \mathrm{g} / \mathrm{L}$ & 48 \\
\hline Iron & 699-23-34B & $\mathrm{Y}$ & 23 & 241 & 58.04615385 & $\mu \mathrm{g} / \mathrm{L}$ & 26 \\
\hline Iron & 699-24-33 & $\mathrm{N}$ & 0 & 4130 & 504.9444444 & $\mu \mathrm{g} / \mathrm{L}$ & 9 \\
\hline Iron & 699-24-33 & $\mathrm{Y}$ & 0 & 174 & 25.83913043 & $\mu \mathrm{g} / \mathrm{L}$ & 46 \\
\hline Iron & 699-24-34A & $\mathrm{N}$ & 60 & 1620 & 455.3 & $\mu \mathrm{g} / \mathrm{L}$ & 15 \\
\hline Iron & 699-24-34A & $\mathrm{Y}$ & 0 & 253 & 63.03913043 & $\mu \mathrm{g} / \mathrm{L}$ & 46 \\
\hline Iron & 699-24-34B & $\mathrm{N}$ & 29 & 4620 & 594.84375 & $\mu \mathrm{g} / \mathrm{L}$ & 16 \\
\hline Iron & 699-24-34B & $\mathrm{Y}$ & 0 & 408 & 55.28333333 & $\mu \mathrm{g} / \mathrm{L}$ & 48 \\
\hline Iron & 699-24-34C & $\mathrm{N}$ & 55 & 1030 & 319.4117647 & $\mu \mathrm{g} / \mathrm{L}$ & 17 \\
\hline Iron & 699-24-34C & $\mathrm{Y}$ & 0 & 103 & 46.31122449 & $\mu \mathrm{g} / \mathrm{L}$ & 49 \\
\hline Iron & 699-24-35 & $\mathrm{N}$ & 0 & 2080 & 243.6176471 & $\mu \mathrm{g} / \mathrm{L}$ & 17 \\
\hline Iron & 699-24-35 & $\mathrm{Y}$ & 0 & 410000 & 8417.107143 & $\mu \mathrm{g} / \mathrm{L}$ & 49 \\
\hline Iron & $699-25-34 \mathrm{C}$ & $\mathrm{N}$ & 28 & 34000 & 2390.125 & $\mu \mathrm{g} / \mathrm{L}$ & 16 \\
\hline Iron & 699-25-34C & $\mathrm{Y}$ & \begin{tabular}{|l|}
0 \\
\end{tabular} & 400 & 46.87083333 & $\mu \mathrm{g} / \mathrm{L}$ & 48 \\
\hline Iron & 699-26-35A & $\mathrm{N}$ & 0 & 4610 & 734.0357143 & $\mu \mathrm{g} / \mathrm{L}$ & 14 \\
\hline Iron & 699-26-35A & $\mathrm{Y}$ & 0 & 99.3 & 22.6 & $\mu \mathrm{g} / \mathrm{L}$ & 41 \\
\hline Lead & 699-23-34A & $\mathrm{N}$ & 0 & 7.5 & 0.681818182 & $\mu \mathrm{g} / \mathrm{L}$ & 11 \\
\hline Lead & 699-24-34A & $\mathrm{N}$ & 0 & 8 & 0.727272727 & $\mu \mathrm{g} / \mathrm{L}$ & 11 \\
\hline Lead & 699-24-34B & \begin{tabular}{|l|}
$\mathrm{N}$ \\
\end{tabular} & 0 & 7 & 0.75 & $\mu \mathrm{g} / \mathrm{L}$ & 11 \\
\hline Lead & 699-24-34C & $\mathrm{N}$ & 0 & 3 & 0.272727273 & $\mu \mathrm{g} / \mathrm{L}$ & 11 \\
\hline Lead & 699-25-34C & $\mathrm{N}$ & 0 & 7 & 0.95 & $\mu \mathrm{g} / \mathrm{L}$ & 10 \\
\hline Lead & 699-26-35A & $\mathrm{N}$ & 0 & 5.8 & 0.527272727 & $\mu \mathrm{g} / \mathrm{L}$ & 11 \\
\hline Lead & 699-26-35A & $\mathrm{Y}$ & 0 & 5.8 & 2.9 & $\mu \mathrm{g} / \mathrm{L}$ & 2 \\
\hline Lithium & 699-23-34A & $\mathrm{N}$ & 0 & 10.5 & 2.928571429 & $\mu \mathrm{g} / \mathrm{L}$ & 7 \\
\hline Lithium & 699-23-34A & \begin{tabular}{|l|}
$\mathrm{Y}$ \\
\end{tabular} & 0 & 11.5 & 1.916666667 & $\mu \mathrm{g} / \mathrm{L}$ & 6 \\
\hline Lithium & 699-24-34B & $\mathrm{N}$ & 0 & 11 & 1.833333333 & $\mu \mathrm{g} / \mathrm{L}$ & 6 \\
\hline Lithium & 699-24-34B & $\mathrm{Y}$ & 0 & 10 & 1.666666667 & $\mu \mathrm{g} / \mathrm{L}$ & 6 \\
\hline M+P-Xylene & 699-24-34B & $\mathrm{N}$ & 0 & 0.3 & 0.042857143 & $\mu \mathrm{g} / \mathrm{L}$ & 7 \\
\hline M+P-Xylene & 699-26-35A & $\mathrm{N}$ & 0 & 0.5 & 0.0625 & $\mu \mathrm{g} / \mathrm{L}$ & 8 \\
\hline Magnesium & 699-22-35 & $\mathrm{Y}$ & 21000 & 28900 & 25448.07692 & $\mu \mathrm{g} / \mathrm{L}$ & 26 \\
\hline Magnesium & 699-23-34A & $\mathrm{N}$ & 14700 & 17500 & 16067.64706 & $\mu \mathrm{g} / \mathrm{L}$ & 17 \\
\hline Magnesium & 699-23-34A & \begin{tabular}{|l|}
$\mathrm{Y}$ \\
\end{tabular} & \begin{tabular}{|l|}
13900 \\
\end{tabular} & 22500 & 18137.5 & $\mu \mathrm{g} / \mathrm{L}$ & 48 \\
\hline Magnesium & 699-23-34B & $\mathrm{Y}$ & 15800 & 25300 & 21688.46154 & $\mu \mathrm{g} / \mathrm{L}$ & 26 \\
\hline Magnesium & \begin{tabular}{|l|}
$699-24-33$ \\
\end{tabular} & \begin{tabular}{|l|}
$\mathrm{N}$ \\
\end{tabular} & \begin{tabular}{|l|}
13700 \\
\end{tabular} & 17000 & 15362.5 & $\mu \mathrm{g} / \mathrm{L}$ & 8 \\
\hline Magnesium & 699-24-33 & $\mathrm{Y}$ & 14400 & 24600 & 18476.08696 & $\mu \mathrm{g} / \mathrm{L}$ & 46 \\
\hline Magnesium & 699-24-34A & $\mathrm{N}$ & \begin{tabular}{|l|}
14050 \\
\end{tabular} & 17000 & 15290 & $\mu \mathrm{g} / \mathrm{L}$ & 15 \\
\hline Magnesium & 699-24-34A & $\mathrm{Y}$ & 14400 & 21000 & 17207.6087 & $\mu \mathrm{g} / \mathrm{L}$ & 46 \\
\hline Magnesium & 699-24-34B & $\mathrm{N}$ & 14500 & 18800 & 16031.25 & $\mu \mathrm{g} / \mathrm{L}$ & 16 \\
\hline Magnesium & 699-24-34B & $\mathrm{Y}$ & 14600 & 22000 & 17678.125 & $\mu \mathrm{g} / \mathrm{L}$ & 48 \\
\hline
\end{tabular}




\begin{tabular}{|c|c|c|c|c|c|c|c|}
\hline Constituent & Well Number & Filtered & Minimum & Maximum & Average & Units & \begin{tabular}{|c|} 
Number of \\
Samples \\
\end{tabular} \\
\hline Magnesium & 699-24-34C & $\mathrm{N}$ & 14300 & 17000 & 15429.41176 & $\mu \mathrm{g} / \mathrm{L}$ & 17 \\
\hline Magnesium & 699-24-34C & $\mathrm{Y}$ & 14700 & 22000 & 18128.57143 & $\mu \mathrm{g} / \mathrm{L}$ & 49 \\
\hline Magnesium & 699-24-35 & $\mathrm{N}$ & 10500 & 14900 & 11697.05882 & $\mu \mathrm{g} / \mathrm{L}$ & 17 \\
\hline Magnesium & 699-24-35 & $\mathrm{Y}$ & 1400 & 180000 & 16800 & $\mu \mathrm{g} / \mathrm{L}$ & 49 \\
\hline Magnesium & 699-25-34C & $\mathrm{N}$ & 10400 & 15000 & 11918.75 & $\mu \mathrm{g} / \mathrm{L}$ & 16 \\
\hline Magnesium & 699-25-34C & $\mathrm{Y}$ & 10600 & 21300 & 15482.29167 & $\mu \mathrm{g} / \mathrm{L}$ & 48 \\
\hline Magnesium & 699-26-35A & $\mathrm{N}$ & 9500 & 13000 & 11164.28571 & $\mu \mathrm{g} / \mathrm{L}$ & 14 \\
\hline Magnesium & 699-26-35A & $\mathrm{Y}$ & 10200 & 17500 & 13160.97561 & $\mu \mathrm{g} / \mathrm{L}$ & 41 \\
\hline Manganese & 699-22-35 & $\mathrm{Y}$ & 0.315 & 72 & 6.847884615 & $\mu \mathrm{g} / \mathrm{L}$ & 26 \\
\hline Manganese & 699-23-34A & $\mathrm{N}$ & 0 & 6 & 0.352941176 & $\mu \mathrm{g} / \mathrm{L}$ & 17 \\
\hline Manganese & 699-23-34A & $\mathrm{Y}$ & 0 & 6 & 1.935 & $\mu \mathrm{g} / \mathrm{L}$ & 48 \\
\hline Manganese & 699-23-34B & $\mathrm{Y}$ & 0.67 & 59 & 6.056538462 & $\mu \mathrm{g} / \mathrm{L}$ & 26 \\
\hline Manganese & 699-24-33 & $\mathrm{N}$ & 0 & 40.8 & 4.533333333 & $\mu \mathrm{g} / \mathrm{L}$ & 9 \\
\hline Manganese & 699-24-33 & $\mathrm{Y}$ & 0 & 6.4 & 1.486847826 & $\mu \mathrm{g} / \mathrm{L}$ & 46 \\
\hline Manganese & 699-24-34A & $\mathrm{N}$ & 0 & 15 & 3.592666667 & $\mu \mathrm{g} / \mathrm{L}$ & 15 \\
\hline Manganese & 699-24-34A & $\mathrm{Y}$ & 0 & 6.4 & 1.813695652 & $\mu \mathrm{g} / \mathrm{L}$ & 46 \\
\hline Manganese & 699-24-34B & $\mathrm{N}$ & 0 & 36 & 3.0625 & $\mu \mathrm{g} / \mathrm{L}$ & 16 \\
\hline Manganese & 699-24-34B & $\mathrm{Y}$ & 0 & 17 & 2.075 & $\mu \mathrm{g} / \mathrm{L}$ & 48 \\
\hline Manganese & 699-24-34C & $\mathrm{N}$ & 0 & 37 & 3.705882353 & $\mu \mathrm{g} / \mathrm{L}$ & 17 \\
\hline Manganese & 699-24-34C & $\mathrm{Y}$ & 0 & 35 & 2.988163265 & $\mu \mathrm{g} / \mathrm{L}$ & 49 \\
\hline Manganese & 699-24-35 & $\mathrm{N}$ & 0 & 9 & 0.882352941 & $\mu \mathrm{g} / \mathrm{L}$ & 17 \\
\hline Manganese & 699-24-35 & $\mathrm{Y}$ & 0 & 7900 & 162.7493878 & $\mu \mathrm{g} / \mathrm{L}$ & 49 \\
\hline Manganese & 699-25-34C & $\mathrm{N}$ & 0 & 42 & 3.8125 & $\mu \mathrm{g} / \mathrm{L}$ & 16 \\
\hline Manganese & 699-25-34C & $\mathrm{Y}$ & 0 & 75 & 3.4484375 & $\mu \mathrm{g} / \mathrm{L}$ & 48 \\
\hline Manganese & 699-26-35A & $\mathrm{N}$ & 0 & 44 & 6.571428571 & $\mu \mathrm{g} / \mathrm{L}$ & 14 \\
\hline Manganese & 699-26-35A & $\mathrm{Y}$ & 0 & 11 & 1.54902439 & $\mu \mathrm{g} / \mathrm{L}$ & 41 \\
\hline Methylenechloride & $699-22-35$ & $\mathrm{~N}$ & 0 & 0.7 & 0.042692308 & $\mu \mathrm{g} / \mathrm{L}$ & 26 \\
\hline Methylenechloride & 699-23-34A & $\mathrm{N}$ & 0 & 3 & 0.068711538 & $\mu \mathrm{g} / \mathrm{L}$ & 53 \\
\hline Methylenechloride & 699-23-34B & $\mathrm{N}$ & 0 & 0.35 & 0.024230769 & $\mu \mathrm{g} / \mathrm{L}$ & 26 \\
\hline Methylenechloride & 699-24-33 & $\mathrm{N}$ & 0 & 4 & 0.096557692 & $\mu \mathrm{g} / \mathrm{L}$ & 53 \\
\hline Methylenechloride & 699-24-34A & $\mathrm{N}$ & 0 & 1200 & 24.08378 & $\mu \mathrm{g} / \mathrm{L}$ & 51 \\
\hline Methylenechloride & 699-24-34B & $\mathrm{N}$ & 0 & 3 & 0.081764706 & $\mu \mathrm{g} / \mathrm{L}$ & 52 \\
\hline Methylenechloride & 699-24-34C & $\mathrm{N}$ & 0 & 160 & 3.113846154 & $\mu \mathrm{g} / \mathrm{L}$ & 53 \\
\hline Methylenechloride & 699-24-35 & $\mathrm{N}$ & 0 & 510 & 10.09931373 & $\mu \mathrm{g} / \mathrm{L}$ & 52 \\
\hline Methylenechloride & 699-25-34C & $\mathrm{N}$ & 0 & 3.5 & 0.07358 & $\mu \mathrm{g} / \mathrm{L}$ & 51 \\
\hline Methylenechloride & 699-26-35A & $\mathrm{N}$ & 0 & 6 & 0.254357143 & $\mu \mathrm{g} / \mathrm{L}$ & 42 \\
\hline Monobutyl phosphate & 699-26-35A & $\mathrm{N}$ & 10000 & 10000 & 10000 & $\mu \mathrm{g} / \mathrm{L}$ & 1 \\
\hline N-Phenylthiourea & 699-23-34A & $\mathrm{N}$ & 500 & 500 & 500 & $\mu \mathrm{g} / \mathrm{L}$ & 1 \\
\hline N-Phenylthiourea & 699-24-34A & $\mathrm{N}$ & 500 & 500 & 500 & $\mu \mathrm{g} / \mathrm{L}$ & 1 \\
\hline N-Phenylthiourea & 699-24-34B & $\mathrm{N}$ & 500 & 500 & 500 & $\mu \mathrm{g} / \mathrm{L}$ & 1 \\
\hline N-Phenylthiourea & 699-24-34C & $\mathrm{N}$ & 500 & 500 & 500 & $\mu \mathrm{g} / \mathrm{L}$ & 1 \\
\hline N-Phenylthiourea & 699-24-35 & $\mathrm{N}$ & 500 & 500 & 500 & $\mu \mathrm{g} / \mathrm{L}$ & 1 \\
\hline N-Phenylthiourea & $699-25-34 \mathrm{C}$ & $\mathrm{N}$ & 500 & 500 & 500 & $\mu \mathrm{g} / \mathrm{L}$ & 1 \\
\hline N-Phenylthiourea & 699-26-35A & $\mathrm{N}$ & 500 & 500 & 500 & $\mu \mathrm{g} / \mathrm{L}$ & 1 \\
\hline
\end{tabular}




\begin{tabular}{|c|c|c|c|c|c|c|c|}
\hline Constituent & Well Number & Filtered & Minimum & Maximum & Average & Units & $\begin{array}{c}\text { Number of } \\
\text { Samples }\end{array}$ \\
\hline Nickel & $699-22-35$ & $\mathrm{Y}$ & 0 & 19 & 1.1 & $\mu \mathrm{g} / \mathrm{L}$ & 26 \\
\hline Nickel & $699-23-34 \mathrm{~A}$ & $\mathrm{~N}$ & 0 & 11 & 0.647058824 & $\mu \mathrm{g} / \mathrm{L}$ & 17 \\
\hline Nickel & 699-23-34A & $\mathrm{Y}$ & 0 & 48 & 1.229166667 & $\mu \mathrm{g} / \mathrm{L}$ & 48 \\
\hline Nickel & 699-23-34B & $\mathrm{Y}$ & 0 & 13 & 0.946153846 & $\mu \mathrm{g} / \mathrm{L}$ & 26 \\
\hline Nickel & 699-24-34A & $\mathrm{Y}$ & 0 & 15 & 0.326086957 & $\mu \mathrm{g} / \mathrm{L}$ & 46 \\
\hline Nickel & 699-24-34B & $\mathrm{Y}$ & 0 & 11.1 & 0.460416667 & $\mu \mathrm{g} / \mathrm{L}$ & 48 \\
\hline Nickel & $699-24-34 \mathrm{C}$ & $\mathrm{N}$ & 0 & 19 & 1.117647059 & $\mu \mathrm{g} / \mathrm{L}$ & 17 \\
\hline Nickel & $699-24-34 \mathrm{C}$ & $\mathrm{Y}$ & 0 & 18 & 0.846938776 & $\mu \mathrm{g} / \mathrm{L}$ & 49 \\
\hline Nickel & 699-24-35 & $\mathrm{N}$ & 0 & 10 & 0.588235294 & $\mu \mathrm{g} / \mathrm{L}$ & 17 \\
\hline Nickel & 699-24-35 & $\mathrm{Y}$ & 0 & 580 & 14.57346939 & $\mu \mathrm{g} / \mathrm{L}$ & 49 \\
\hline Nickel & $699-25-34 \mathrm{C}$ & $\mathrm{N}$ & 0 & 12 & 0.75 & $\mu \mathrm{g} / \mathrm{L}$ & 16 \\
\hline Nickel & $699-25-34 \mathrm{C}$ & $\mathrm{Y}$ & 0 & 430 & 9.566666667 & $\mu \mathrm{g} / \mathrm{L}$ & 48 \\
\hline Nickel & 699-26-35A & $\mathrm{Y}$ & 0 & 11.4 & 0.551219512 & $\mu \mathrm{g} / \mathrm{L}$ & 41 \\
\hline Nitrate & $699-22-35$ & $\mathrm{~N}$ & 11000 & 15582.336 & 13971.77908 & $\mu \mathrm{g} / \mathrm{L}$ & 26 \\
\hline Nitrate & 699-23-34A & $\mathrm{N}$ & 10491.516 & 510000 & 25933.17992 & $\mu \mathrm{g} / \mathrm{L}$ & 51 \\
\hline Nitrate & 699-23-34B & $\mathrm{N}$ & 11000 & 22842.288 & 13424.018 & $\mu \mathrm{g} / \mathrm{L}$ & 26 \\
\hline Nitrate & $699-24-33$ & $\mathrm{~N}$ & 14165.76 & 40000 & 25806.64702 & $\mu \mathrm{g} / \mathrm{L}$ & 63 \\
\hline Nitrate & 699-24-34A & $\mathrm{N}$ & 11000 & 33150 & 17627.07592 & $\mu \mathrm{g} / \mathrm{L}$ & 49 \\
\hline Nitrate & 699-24-34B & $\mathrm{N}$ & 11509.68 & 35900 & 20671.15632 & $\mu \mathrm{g} / \mathrm{L}$ & 50 \\
\hline Nitrate & $699-24-34 \mathrm{C}$ & $\mathrm{N}$ & 14165.76 & 37000 & 24712.93565 & $\mu \mathrm{g} / \mathrm{L}$ & 51 \\
\hline Nitrate & $699-24-35$ & $\mathrm{~N}$ & 10491.516 & 29400 & 16099.26757 & $\mu \mathrm{g} / \mathrm{L}$ & 51 \\
\hline Nitrate & $699-25-34 \mathrm{C}$ & $\mathrm{N}$ & 17264.52 & 35100 & 26089.8278 & $\mu \mathrm{g} / \mathrm{L}$ & 50 \\
\hline Nitrate & 699-26-35A & $\mathrm{N}$ & 19654.992 & 33800 & 25379.06715 & $\mu \mathrm{g} / \mathrm{L}$ & 47 \\
\hline Nitrite & 699-24-34C & $\mathrm{N}$ & 0 & 1130 & 24.56521739 & $\mu \mathrm{g} / \mathrm{L}$ & 46 \\
\hline o-Xylene & 699-24-34A & $\mathrm{N}$ & 0 & 0.21 & 0.03 & $\mu \mathrm{g} / \mathrm{L}$ & 7 \\
\hline o-Xylene & 699-24-34B & $\mathrm{N}$ & 0 & 0.23 & 0.032857143 & $\mu \mathrm{g} / \mathrm{L}$ & 7 \\
\hline o-Xylene & $699-25-34 \mathrm{C}$ & $\mathrm{N}$ & 0 & 0.17 & 0.024285714 & $\mu \mathrm{g} / \mathrm{L}$ & 7 \\
\hline pH Measurement & $699-22-35$ & $\mathrm{~N}$ & 6.595 & 7.2175 & 6.913240741 & $\mathrm{pH}$ & 27 \\
\hline pH Measurement & 699-23-34A & $\mathrm{N}$ & 5.1 & 7.61 & 6.675740741 & $\mathrm{pH}$ & 54 \\
\hline $\mathrm{pH}$ Measurement & 699-23-34B & $\mathrm{N}$ & 6.7025 & 8.03 & 6.924296296 & $\mathrm{pH}$ & 27 \\
\hline pH Measurement & $699-24-33$ & $\mathrm{~N}$ & 6.6875 & 7.755 & 7.150125 & $\mathrm{pH}$ & 60 \\
\hline pH Measurement & 699-24-34A & $\mathrm{N}$ & 3.9 & 7.425 & 6.6997 & $\mathrm{pH}$ & 50 \\
\hline pH Measurement & 699-24-34B & $\mathrm{N}$ & 3.5 & 7.3 & 6.725735294 & $\mathrm{pH}$ & 51 \\
\hline pH Measurement & 699-24-34C & $\mathrm{N}$ & 6.3 & 7.6 & 6.9675 & $\mathrm{pH}$ & 52 \\
\hline pH Measurement & 699-24-35 & $\mathrm{N}$ & 5.5 & 8.45 & 7.113621795 & $\mathrm{pH}$ & 52 \\
\hline pH Measurement & $699-25-34 \mathrm{C}$ & $\mathrm{N}$ & 6.55 & 7.8 & 7.27122549 & $\mathrm{pH}$ & 51 \\
\hline $\mathrm{pH}$ Measurement & 699-26-35A & $\mathrm{N}$ & 5.4 & 8.275 & 7.354460784 & $\mathrm{pH}$ & 51 \\
\hline Phenol & $699-26-35 \mathrm{~A}$ & $\mathrm{~N}$ & 0 & 4.1 & 0.215789474 & $\mu \mathrm{g} / \mathrm{L}$ & 19 \\
\hline Potassium & 699-22-35 & $\mathrm{Y}$ & 7600 & 11000 & 9618.461538 & $\mu \mathrm{g} / \mathrm{L}$ & 26 \\
\hline Potassium & 699-23-34A & $\mathrm{N}$ & 6860 & 8130 & 7500 & $\mu \mathrm{g} / \mathrm{L}$ & 17 \\
\hline Potassium & 699-23-34A & $\mathrm{Y}$ & 6800 & 10100 & 7897.083333 & $\mu \mathrm{g} / \mathrm{L}$ & 48 \\
\hline Potassium & 699-23-34B & $\mathrm{Y}$ & 6850 & 10600 & 8461.923077 & $\mu \mathrm{g} / \mathrm{L}$ & 26 \\
\hline Potassium & $699-24-33$ & $\mathrm{~N}$ & 6170 & 8100 & 7053.888889 & $\mu \mathrm{g} / \mathrm{L}$ & 9 \\
\hline Potassium & 699-24-33 & $\mathrm{Y}$ & 6780 & 8765 & 7737.608696 & $\mu \mathrm{g} / \mathrm{L}$ & 46 \\
\hline Potassium & 699-24-34A & $\mathrm{N}$ & 7020 & 8090 & 7318.333333 & $\mu \mathrm{g} / \mathrm{L}$ & 15 \\
\hline
\end{tabular}

B. 12 


\begin{tabular}{|c|c|c|c|c|c|c|c|}
\hline Constituent & Well Number & Filtered & Minimum & Maximum & Average & Units & $\begin{array}{c}\text { Number of } \\
\text { Samples } \\
\end{array}$ \\
\hline Potassium & 699-24-34A & $\mathrm{Y}$ & 6500 & 9840 & 7736.195652 & $\mu \mathrm{g} / \mathrm{L}$ & 46 \\
\hline Potassium & 699-24-34B & $\mathrm{N}$ & 6910 & 8890 & 7360.3125 & $\mu \mathrm{g} / \mathrm{L}$ & 16 \\
\hline Potassium & 699-24-34B & $\mathrm{Y}$ & 6730 & 8830 & 7702.916667 & $\mu \mathrm{g} / \mathrm{L}$ & 48 \\
\hline Potassium & 699-24-34C & $\mathrm{N}$ & 6350 & 8000 & 7084.117647 & $\mu \mathrm{g} / \mathrm{L}$ & 17 \\
\hline Potassium & 699-24-34C & $\mathrm{Y}$ & 6030 & 9210 & 7681.122449 & $\mu \mathrm{g} / \mathrm{L}$ & 49 \\
\hline Potassium & 699-24-35 & $\mathrm{N}$ & 6120 & 8100 & 6932.058824 & $\mu \mathrm{g} / \mathrm{L}$ & 17 \\
\hline Potassium & 699-24-35 & $\mathrm{Y}$ & 5940 & 22000 & 7712.653061 & $\mu \mathrm{g} / \mathrm{L}$ & 49 \\
\hline Potassium & $699-25-34 \mathrm{C}$ & $\mathrm{N}$ & 5460 & 7100 & 6288.125 & $\mu \mathrm{g} / \mathrm{L}$ & 16 \\
\hline Potassium & $699-25-34 \mathrm{C}$ & $\mathrm{Y}$ & 5980 & 8910 & 7123.958333 & $\mu \mathrm{g} / \mathrm{L}$ & 48 \\
\hline Potassium & $699-26-35 \mathrm{~A}$ & $\mathrm{~N}$ & 5200 & 6900 & 6230 & $\mu \mathrm{g} / \mathrm{L}$ & 14 \\
\hline Potassium & $699-26-35 \mathrm{~A}$ & $\mathrm{Y}$ & 4220 & 8570 & 6600.97561 & $\mu \mathrm{g} / \mathrm{L}$ & 41 \\
\hline Potassium-40 & 699-24-33 & $\mathrm{N}$ & 58.5 & 211 & 98.67500019 & $\mathrm{pCi} / \mathrm{L}$ & 4 \\
\hline Radium & 699-23-34A & $\mathrm{N}$ & 0.168 & 0.364 & 0.234333333 & $\mathrm{pCi} / \mathrm{L}$ & 3 \\
\hline Radium & $699-24-33$ & $\mathrm{~N}$ & -0.00908 & 0.466 & 0.25523 & $\mathrm{pCi} / \mathrm{L}$ & 4 \\
\hline Radium & 699-24-34A & $\mathrm{N}$ & 0.0135 & 0.312 & 0.136766667 & $\mathrm{pCi} / \mathrm{L}$ & 3 \\
\hline Radium & 699-24-34B & $\mathrm{N}$ & -0.0648 & 0.261 & 0.114733333 & $\mathrm{pCi} / \mathrm{L}$ & 3 \\
\hline Radium & 699-24-34C & $\mathrm{N}$ & -0.0176 & 0.128 & 0.071466667 & $\mathrm{pCi} / \mathrm{L}$ & 3 \\
\hline Radium & 699-24-35 & $\mathrm{N}$ & 0.0571 & 0.224 & 0.128366667 & $\mathrm{pCi} / \mathrm{L}$ & 3 \\
\hline Radium & $699-25-34 \mathrm{C}$ & $\mathrm{N}$ & 0.0376 & 0.317 & 0.1652 & $\mathrm{pCi} / \mathrm{L}$ & 3 \\
\hline Radium & $699-26-35 \mathrm{~A}$ & $\mathrm{~N}$ & -0.049 & 0.108 & 0.03209125 & $\mathrm{pCi} / \mathrm{L}$ & 8 \\
\hline Ruthenium-106 & 699-23-34A & $\mathrm{N}$ & -19.8 & 31.5 & 4.724 & $\mathrm{pCi} / \mathrm{L}$ & 5 \\
\hline Ruthenium-106 & 699-24-33 & $\mathrm{N}$ & -32.59999847 & 78.8 & 9.33450016 & $\mathrm{pCi} / \mathrm{L}$ & 20 \\
\hline Ruthenium-106 & 699-24-34A & $\mathrm{N}$ & -33.3 & 24.1 & 4.292 & $\mathrm{pCi} / \mathrm{L}$ & 5 \\
\hline Ruthenium-106 & 699-24-34B & $\mathrm{N}$ & -13.6 & 18.7 & 6.312 & $\mathrm{pCi} / \mathrm{L}$ & 5 \\
\hline Ruthenium-106 & 699-24-34C & $\mathrm{N}$ & -18.7 & -1.05 & -9.326 & $\mathrm{pCi} / \mathrm{L}$ & 5 \\
\hline Ruthenium-106 & 699-24-35 & $\mathrm{N}$ & -6.33 & 51 & 25.534 & $\mathrm{pCi} / \mathrm{L}$ & 5 \\
\hline Ruthenium-106 & $699-25-34 \mathrm{C}$ & $\mathrm{N}$ & -17.7 & 44.9 & 0.976 & $\mathrm{pCi} / \mathrm{L}$ & 5 \\
\hline Selenium & 699-23-34A & $\mathrm{N}$ & 0 & 3 & 0.272727273 & $\mu \mathrm{g} / \mathrm{L}$ & 11 \\
\hline Selenium & $699-24-34 \mathrm{~A}$ & $\mathrm{~N}$ & 0 & 2.5 & 0.227272727 & $\mu \mathrm{g} / \mathrm{L}$ & 11 \\
\hline Silicon & 699-23-34A & $\mathrm{N}$ & 19100 & 21700 & 20242.85714 & $\mu \mathrm{g} / \mathrm{L}$ & 7 \\
\hline Silicon & 699-23-34A & $\mathrm{Y}$ & 18600 & 21000 & 20025 & $\mu \mathrm{g} / \mathrm{L}$ & 6 \\
\hline Silicon & 699-24-33 & $\mathrm{N}$ & 18600 & 20900 & 19730 & $\mu \mathrm{g} / \mathrm{L}$ & 5 \\
\hline Silicon & $699-24-33$ & $\mathrm{Y}$ & 19600 & 23200 & 20620 & $\mu \mathrm{g} / \mathrm{L}$ & 5 \\
\hline Silicon & 699-24-34A & $\mathrm{N}$ & 18700 & 21700 & 19810 & $\mu \mathrm{g} / \mathrm{L}$ & 5 \\
\hline Silicon & 699-24-34A & $\mathrm{Y}$ & 19100 & 20000 & 19725 & $\mu \mathrm{g} / \mathrm{L}$ & 4 \\
\hline Silicon & 699-24-34B & $\mathrm{N}$ & 19550 & 24600 & 21041.66667 & $\mu \mathrm{g} / \mathrm{L}$ & 6 \\
\hline Silicon & 699-24-34B & $\mathrm{Y}$ & 20100 & 21300 & 20650 & $\mu \mathrm{g} / \mathrm{L}$ & 6 \\
\hline Silicon & 699-24-34C & $\mathrm{N}$ & 18800 & 21800 & 19585.71429 & $\mu \mathrm{g} / \mathrm{L}$ & 7 \\
\hline Silicon & 699-24-34C & $\mathrm{Y}$ & 18600 & 22300 & 20200 & $\mu \mathrm{g} / \mathrm{L}$ & 7 \\
\hline Silicon & 699-24-35 & $\mathrm{N}$ & 17800 & 21700 & 19557.14286 & $\mu \mathrm{g} / \mathrm{L}$ & 7 \\
\hline Silicon & 699-24-35 & $\mathrm{Y}$ & 17800 & 21950 & 19307.14286 & $\mu \mathrm{g} / \mathrm{L}$ & 7 \\
\hline Silicon & $699-25-34 \mathrm{C}$ & $\mathrm{N}$ & 18400 & 22700 & 20057.14286 & $\mu \mathrm{g} / \mathrm{L}$ & 7 \\
\hline Silicon & $699-25-34 \mathrm{C}$ & $\mathrm{Y}$ & 18900 & 23300 & 20357.14286 & $\mu \mathrm{g} / \mathrm{L}$ & 7 \\
\hline Silicon & 699-26-35A & $\mathrm{N}$ & 18700 & 18700 & 18700 & $\mu \mathrm{g} / \mathrm{L}$ & 1 \\
\hline Silicon & 699-26-35A & $\mathrm{Y}$ & 19800 & 19800 & 19800 & $\mu \mathrm{g} / \mathrm{L}$ & 1 \\
\hline
\end{tabular}




\begin{tabular}{|c|c|c|c|c|c|c|c|}
\hline Constituent & Well Number & Filtered & Minimum & Maximum & Average & Units & \begin{tabular}{|c|} 
Number of \\
Samples \\
\end{tabular} \\
\hline Silver & 699-22-35 & $\mathrm{Y}$ & 0 & 8.7 & 0.615384615 & $\mu \mathrm{g} / \mathrm{L}$ & 26 \\
\hline Silver & 699-23-34A & $\mathrm{Y}$ & 0 & 5.6 & 0.116666667 & $\mu \mathrm{g} / \mathrm{L}$ & 48 \\
\hline Silver & 699-23-34B & $\mathrm{Y}$ & 0 & 5.7 & 0.219230769 & $\mu \mathrm{g} / \mathrm{L}$ & 26 \\
\hline Silver & 699-24-33 & $\mathrm{Y}$ & 0 & 5.3 & 0.115217391 & $\mu \mathrm{g} / \mathrm{L}$ & 46 \\
\hline Silver & 699-24-34A & $\mathrm{Y}$ & 0 & 27 & 0.586956522 & $\mu \mathrm{g} / \mathrm{L}$ & 46 \\
\hline Silver & 699-24-34B & $\mathrm{N}$ & 0 & 11 & 0.6875 & $\mu \mathrm{g} / \mathrm{L}$ & 16 \\
\hline Silver & 699-24-34B & $\mathrm{Y}$ & 0 & 3 & 0.0625 & $\mu \mathrm{g} / \mathrm{L}$ & 48 \\
\hline Silver & $699-24-34 \mathrm{C}$ & $\mathrm{Y}$ & 0 & 5.9 & 0.330612245 & $\mu \mathrm{g} / \mathrm{L}$ & 49 \\
\hline Silver & 699-24-35 & $\mathrm{Y}$ & 0 & 8.2 & 0.344897959 & $\mu \mathrm{g} / \mathrm{L}$ & 49 \\
\hline Silver & 699-25-34C & $\mathrm{Y}$ & 0 & 9.6 & 0.2 & $\mu \mathrm{g} / \mathrm{L}$ & 48 \\
\hline Silver & 699-26-35A & $\mathrm{Y}$ & 0 & 6.4 & 0.236585366 & $\mu \mathrm{g} / \mathrm{L}$ & 41 \\
\hline Sodium & 699-22-35 & $\mathrm{Y}$ & 22000 & 27000 & 24628.84615 & $\mu \mathrm{g} / \mathrm{L}$ & 26 \\
\hline Sodium & 699-23-34A & $\mathrm{N}$ & 20400 & 25000 & 22488.23529 & $\mu \mathrm{g} / \mathrm{L}$ & 17 \\
\hline Sodium & 699-23-34A & $\mathrm{Y}$ & 20000 & 25000 & 22619.79167 & $\mu \mathrm{g} / \mathrm{L}$ & 48 \\
\hline Sodium & 699-23-34B & $\mathrm{Y}$ & 22000 & 26000 & 23690.38462 & $\mu \mathrm{g} / \mathrm{L}$ & 26 \\
\hline Sodium & 699-24-33 & $\mathrm{N}$ & 20600 & 24100 & 22637.03704 & $\mu \mathrm{g} / \mathrm{L}$ & 9 \\
\hline Sodium & 699-24-33 & $\mathrm{Y}$ & 20000 & 26200 & 23557.6087 & $\mu \mathrm{g} / \mathrm{L}$ & 46 \\
\hline Sodium & 699-24-34A & $\mathrm{N}$ & 21100 & 26100 & 22706.66667 & $\mu \mathrm{g} / \mathrm{L}$ & 15 \\
\hline Sodium & 699-24-34A & $\mathrm{Y}$ & 20000 & 26900 & 22782.6087 & $\mu \mathrm{g} / \mathrm{L}$ & 46 \\
\hline Sodium & 699-24-34B & $\mathrm{N}$ & 21600 & 28600 & 22996.875 & $\mu \mathrm{g} / \mathrm{L}$ & 16 \\
\hline Sodium & 699-24-34B & $\mathrm{Y}$ & 19850 & 26300 & 23090.625 & $\mu \mathrm{g} / \mathrm{L}$ & 48 \\
\hline Sodium & $699-24-34 \mathrm{C}$ & $\mathrm{N}$ & 20600 & 26200 & 22582.35294 & $\mu \mathrm{g} / \mathrm{L}$ & 17 \\
\hline Sodium & 699-24-34C & $\mathrm{Y}$ & 19600 & 27000 & 23392.85714 & $\mu \mathrm{g} / \mathrm{L}$ & 49 \\
\hline Sodium & 699-24-35 & $\mathrm{N}$ & 20800 & 26150 & 22626.47059 & $\mu \mathrm{g} / \mathrm{L}$ & 17 \\
\hline Sodium & 699-24-35 & $\mathrm{Y}$ & 20000 & 74000 & 23530.61224 & $\mu \mathrm{g} / \mathrm{L}$ & 49 \\
\hline Sodium & $699-25-34 \mathrm{C}$ & $\mathrm{N}$ & 20600 & 27000 & 23050 & $\mu \mathrm{g} / \mathrm{L}$ & 16 \\
\hline Sodium & $699-25-34 \mathrm{C}$ & $\mathrm{Y}$ & 19500 & 27000 & 23731.25 & $\mu \mathrm{g} / \mathrm{L}$ & 48 \\
\hline Sodium & 699-26-35A & $\mathrm{N}$ & 20500 & 24100 & 22564.28571 & $\mu \mathrm{g} / \mathrm{L}$ & 14 \\
\hline Sodium & 699-26-35A & $\mathrm{Y}$ & 20900 & 27000 & 23358.53659 & $\mu \mathrm{g} / \mathrm{L}$ & 41 \\
\hline Specific Conductance & $699-22-35$ & $\mathrm{~N}$ & 484.25 & 1556.75 & 786.1851852 & $\mu \mathrm{S} / \mathrm{cm}$ & 27 \\
\hline Specific conductance & 699-23-34A & $\mathrm{N}$ & 265.5 & 1248 & 613.712963 & $\mu \mathrm{S} / \mathrm{cm}$ & 54 \\
\hline Specific Conductance & 699-23-34B & $\mathrm{N}$ & 441.75 & 1426.75 & 745.6888889 & $\mu \mathrm{S} / \mathrm{cm}$ & 27 \\
\hline Specific conductance & 699-24-33 & $\mathrm{N}$ & 299.75 & 1323 & 618.1958333 & $\mu \mathrm{S} / \mathrm{cm}$ & 60 \\
\hline Specific conductance & 699-24-34A & $\mathrm{N}$ & 439 & 1232 & 591.625 & $\mu \mathrm{S} / \mathrm{cm}$ & 50 \\
\hline Specific conductance & 699-24-34B & $\mathrm{N}$ & 285.75 & 1251 & 614.0784314 & $\mu \mathrm{S} / \mathrm{cm}$ & 51 \\
\hline Specific conductance & 699-24-34C & $\mathrm{N}$ & 388.5 & 1344.25 & 641.4375 & $\mu \mathrm{S} / \mathrm{cm}$ & 52 \\
\hline Specific conductance & 699-24-35 & $\mathrm{N}$ & 280.25 & 1032.25 & 488.3365385 & $\mu \mathrm{S} / \mathrm{cm}$ & 52 \\
\hline Specific conductance & $699-25-34 \mathrm{C}$ & $\mathrm{N}$ & 287 & 1120 & 511.5147059 & $\mu \mathrm{S} / \mathrm{cm}$ & 51 \\
\hline Specific conductance & 699-26-35A & $\mathrm{N}$ & 206 & 912.25 & 429.4460784 & $\mu \mathrm{S} / \mathrm{cm}$ & 51 \\
\hline Strontium (elemental) & 699-22-35 & $\mathrm{Y}$ & 450 & 605 & 533.9 & $\mu \mathrm{g} / \mathrm{L}$ & 20 \\
\hline Strontium (elemental) & 699-23-34A & $\mathrm{N}$ & 273 & 321 & 295.5384615 & $\mu \mathrm{g} / \mathrm{L}$ & 13 \\
\hline Strontium (elemental) & 699-23-34A & $\mathrm{Y}$ & 0 & 425 & 327.46875 & $\mu \mathrm{g} / \mathrm{L}$ & 32 \\
\hline Strontium (elemental) & 699-23-34B & $\mathrm{Y}$ & 269 & 533 & 452.925 & $\mu \mathrm{g} / \mathrm{L}$ & 20 \\
\hline Strontium (elemental) & 699-24-33 & $\mathrm{N}$ & 256 & 290 & 277.6666667 & $\mu \mathrm{g} / \mathrm{L}$ & 6 \\
\hline
\end{tabular}




\begin{tabular}{|c|c|c|c|c|c|c|c|}
\hline Constituent & Well Number & Filtered & Minimum & Maximum & Average & Units & \begin{tabular}{|c|} 
Number of \\
Samples \\
\end{tabular} \\
\hline 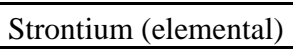 & 699-24-33 & $\mathrm{Y}$ & 0 & 447 & 307.6875 & $\mu \mathrm{g} / \mathrm{L}$ & 32 \\
\hline Strontium (elemental) & 699-24-34A & $\mathrm{N}$ & 0 & 301 & 244.1818182 & $\mu \mathrm{g} / \mathrm{L}$ & 11 \\
\hline Strontium (elemental) & 699-24-34A & $\mathrm{Y}$ & 0 & 376 & 299.85 & $\mu \mathrm{g} / \mathrm{L}$ & 30 \\
\hline Strontium (elemental) & 699-24-34B & $\mathrm{N}$ & 0 & 351 & 262.375 & $\mu \mathrm{g} / \mathrm{L}$ & 12 \\
\hline Strontium (elemental) & 699-24-34B & $\mathrm{Y}$ & 0 & 389 & 305.109375 & $\mu \mathrm{g} / \mathrm{L}$ & 32 \\
\hline Strontium (elemental) & 699-24-34C & $\mathrm{N}$ & 0 & 324 & 261.8461538 & $\mu \mathrm{g} / \mathrm{L}$ & 13 \\
\hline Strontium (elemental) & 699-24-34C & $\mathrm{Y}$ & 0 & 410 & 321.469697 & $\mu \mathrm{g} / \mathrm{L}$ & 33 \\
\hline Strontium (elemental) & 699-24-35 & $\mathrm{N}$ & 0 & 274 & 197.8076923 & $\mu \mathrm{g} / \mathrm{L}$ & 13 \\
\hline Strontium (elemental) & 699-24-35 & $\mathrm{Y}$ & 0 & 340 & 251.1875 & $\mu \mathrm{g} / \mathrm{L}$ & 32 \\
\hline Strontium (elemental) & $699-25-34 \mathrm{C}$ & $\mathrm{N}$ & 0 & 224 & 184.9166667 & $\mu \mathrm{g} / \mathrm{L}$ & 12 \\
\hline Strontium (elemental) & $699-25-34 \mathrm{C}$ & $\mathrm{Y}$ & 0 & 384 & 260.515625 & $\mu \mathrm{g} / \mathrm{L}$ & 32 \\
\hline Strontium (elemental) & 699-26-35A & $\mathrm{N}$ & 161 & 192 & 176.4 & $\mu \mathrm{g} / \mathrm{L}$ & 5 \\
\hline Strontium (elemental) & 699-26-35A & $\mathrm{Y}$ & 171 & 294 & 224.7916667 & $\mu \mathrm{g} / \mathrm{L}$ & 24 \\
\hline Strontium-90 & 699-23-34A & $\mathrm{N}$ & -0.308 & 0.878 & 0.0772 & $\mathrm{pCi} / \mathrm{L}$ & 4 \\
\hline Strontium-90 & 699-24-33 & $\mathrm{N}$ & -0.374 & 0.512 & 0.08127 & $\mathrm{pCi} / \mathrm{L}$ & 4 \\
\hline Strontium-90 & 699-24-34A & $\mathrm{N}$ & -0.548 & 0.00438 & -0.265405 & $\mathrm{pCi} / \mathrm{L}$ & 4 \\
\hline Strontium-90 & 699-24-34B & $\mathrm{N}$ & -0.285 & 1.23 & 0.268575 & $\mathrm{pCi} / \mathrm{L}$ & 4 \\
\hline Strontium-90 & 699-24-34C & $\mathrm{N}$ & -0.385 & 0.444 & 0.11375 & $\mathrm{pCi} / \mathrm{L}$ & 4 \\
\hline Strontium-90 & 699-24-35 & $\mathrm{N}$ & -0.49 & 0.525 & -0.0065 & $\mathrm{pCi} / \mathrm{L}$ & 4 \\
\hline Strontium-90 & $699-25-34 \mathrm{C}$ & $\mathrm{N}$ & -0.568 & 0.435 & -0.206 & $\mathrm{pCi} / \mathrm{L}$ & 4 \\
\hline Sulfate & $699-22-35$ & $\mathrm{~N}$ & 49000 & 527000 & 71134.61538 & $\mu \mathrm{g} / \mathrm{L}$ & 26 \\
\hline Sulfate & 699-23-34A & $\mathrm{N}$ & 41300 & 73000 & 45894.11765 & $\mu \mathrm{g} / \mathrm{L}$ & 51 \\
\hline Sulfate & 699-23-34B & $\mathrm{N}$ & 39300 & 56400 & 51140.38462 & $\mu \mathrm{g} / \mathrm{L}$ & 26 \\
\hline Sulfate & 699-24-33 & $\mathrm{N}$ & 37000 & 55633.33333 & 42306.72515 & $\mu \mathrm{g} / \mathrm{L}$ & 57 \\
\hline Sulfate & 699-24-34A & $\mathrm{N}$ & 40900 & 57700 & 44513.26531 & $\mu \mathrm{g} / \mathrm{L}$ & 49 \\
\hline Sulfate & 699-24-34B & $\mathrm{N}$ & 37000 & 47700 & 43151 & $\mu \mathrm{g} / \mathrm{L}$ & 50 \\
\hline Sulfate & $699-24-34 \mathrm{C}$ & $\mathrm{N}$ & 32000 & 47000 & 41698.03922 & $\mu \mathrm{g} / \mathrm{L}$ & 51 \\
\hline Sulfate & 699-24-35 & $\mathrm{N}$ & 38400 & 51500 & 44864.70588 & $\mu \mathrm{g} / \mathrm{L}$ & 51 \\
\hline Sulfate & 699-25-34C & $\mathrm{N}$ & 35600 & 51000 & 40783 & $\mu \mathrm{g} / \mathrm{L}$ & 50 \\
\hline Sulfate & 699-26-35A & $\mathrm{N}$ & 33800 & 46700 & 39102.12766 & $\mu \mathrm{g} / \mathrm{L}$ & 47 \\
\hline Technetium-99 & 699-23-34A & $\mathrm{N}$ & 10.9 & 10.9 & 10.9 & $\mathrm{pCi} / \mathrm{L}$ & 1 \\
\hline Technetium-99 & 699-23-34B & $\mathrm{N}$ & 4.09 & 4.09 & 4.09 & $\mathrm{pCi} / \mathrm{L}$ & 1 \\
\hline Technetium-99 & 699-24-33 & $\mathrm{N}$ & 1.070000052 & 1.070000052 & 1.070000052 & $\mathrm{pCi} / \mathrm{L}$ & 1 \\
\hline Temperature & $699-22-35$ & $\mathrm{~N}$ & 16.475 & 19.6 & 17.92037037 & $\operatorname{Deg} C$ & 27 \\
\hline Temperature & 699-23-34A & $\mathrm{N}$ & 15 & 22 & 18.24814815 & Deg C & 54 \\
\hline Temperature & 699-23-34B & $\mathrm{N}$ & 17 & 25 & 18.23037037 & Deg C & 27 \\
\hline Temperature & 699-24-33 & $\mathrm{N}$ & 17 & 21 & 19.53467742 & $\operatorname{Deg} C$ & 62 \\
\hline Temperature & 699-24-34A & $\mathrm{N}$ & 16 & 25.2 & 18.63571429 & Deg C & 49 \\
\hline Temperature & 699-24-34B & $\mathrm{N}$ & 16 & 22 & 18.7005 & Deg C & 50 \\
\hline Temperature & 699-24-34C & $\mathrm{N}$ & 16 & 21 & 18.718 & $\operatorname{Deg} C$ & 50 \\
\hline Temperature & 699-24-35 & $\mathrm{N}$ & 16 & 25 & 18.27320261 & Deg C & 51 \\
\hline Temperature & $699-25-34 \mathrm{C}$ & $\mathrm{N}$ & 17 & 25 & 19.20102041 & $\operatorname{Deg} C$ & 49 \\
\hline Temperature & 699-26-35A & $\mathrm{N}$ & 18.6 & 26.6 & 19.85691489 & Deg C & 47 \\
\hline Tetrachloroethene & 699-22-35 & $\mathrm{N}$ & 1 & 3 & 1.755769231 & $\mu \mathrm{g} / \mathrm{L}$ & 26 \\
\hline Tetrachloroethene & 699-23-34A & $\mathrm{N}$ & 0 & 12 & 4.276470588 & $\mu \mathrm{g} / \mathrm{L}$ & 52 \\
\hline
\end{tabular}




\begin{tabular}{|c|c|c|c|c|c|c|c|}
\hline Constituent & Well Number & Filtered & Minimum & Maximum & Average & Units & \begin{tabular}{|c|} 
Number of \\
Samples \\
\end{tabular} \\
\hline Tetrachloroethene & 699-23-34B & $\mathrm{N}$ & 0.95 & 7 & 2.188846154 & $\mu \mathrm{g} / \mathrm{L}$ & 26 \\
\hline Tetrachloroethene & 699-24-33 & $\mathrm{N}$ & 0 & 11 & 2.822641509 & $\mu \mathrm{g} / \mathrm{L}$ & 54 \\
\hline Tetrachloroethene & 699-24-34A & $\mathrm{N}$ & 0 & 9 & 3.632653061 & $\mu \mathrm{g} / \mathrm{L}$ & 50 \\
\hline Tetrachloroethene & 699-24-34B & $\mathrm{N}$ & 0 & 11 & 4.492 & $\mu \mathrm{g} / \mathrm{L}$ & 51 \\
\hline Tetrachloroethene & 699-24-34C & $\mathrm{N}$ & 0 & 9 & 3.670588235 & $\mu \mathrm{g} / \mathrm{L}$ & 52 \\
\hline Tetrachloroethene & 699-24-35 & $\mathrm{N}$ & 0 & 3 & 0.754117647 & $\mu \mathrm{g} / \mathrm{L}$ & 52 \\
\hline Tetrachloroethene & 699-25-34C & $\mathrm{N}$ & 0 & 6.5 & 1.1948 & $\mu \mathrm{g} / \mathrm{L}$ & 51 \\
\hline Tetrachloroethene & 699-26-35A & $\mathrm{N}$ & 0 & 3 & 0.489047619 & $\mu \mathrm{g} / \mathrm{L}$ & 42 \\
\hline Thiourea & 699-23-34A & $\mathrm{N}$ & 200 & 200 & 200 & $\mu \mathrm{g} / \mathrm{L}$ & 1 \\
\hline Thiourea & 699-24-34A & $\mathrm{N}$ & 200 & 200 & 200 & $\mu \mathrm{g} / \mathrm{L}$ & 1 \\
\hline Thiourea & 699-24-34B & $\mathrm{N}$ & 200 & 200 & 200 & $\mu \mathrm{g} / \mathrm{L}$ & 1 \\
\hline Thiourea & 699-24-34C & $\mathrm{N}$ & 200 & 200 & 200 & $\mu \mathrm{g} / \mathrm{L}$ & 1 \\
\hline Thiourea & 699-24-35 & $\mathrm{N}$ & 200 & 200 & 200 & $\mu \mathrm{g} / \mathrm{L}$ & 1 \\
\hline Thiourea & 699-25-34C & $\mathrm{N}$ & 200 & 200 & 200 & $\mu \mathrm{g} / \mathrm{L}$ & 1 \\
\hline Thiourea & 699-26-35A & $\mathrm{N}$ & 200 & 200 & 200 & $\mu \mathrm{g} / \mathrm{L}$ & 1 \\
\hline Tin & 699-22-35 & $\mathrm{Y}$ & 0 & 28 & 4.5 & $\mu \mathrm{g} / \mathrm{L}$ & 12 \\
\hline Tin & 699-23-34A & $\mathrm{Y}$ & 0 & 69 & 4.269230769 & $\mu \mathrm{g} / \mathrm{L}$ & 26 \\
\hline Tin & 699-23-34B & $\mathrm{Y}$ & 0 & 88 & 10.08333333 & $\mu \mathrm{g} / \mathrm{L}$ & 12 \\
\hline Tin & 699-24-33 & $\mathrm{Y}$ & 0 & 41 & 2.92 & $\mu \mathrm{g} / \mathrm{L}$ & 25 \\
\hline Tin & 699-24-34A & $\mathrm{Y}$ & 0 & 44 & 1.833333333 & $\mu \mathrm{g} / \mathrm{L}$ & 24 \\
\hline Tin & 699-24-34B & $\mathrm{Y}$ & 0 & 50 & 4.230769231 & $\mu \mathrm{g} / \mathrm{L}$ & 26 \\
\hline Tin & 699-24-35 & $\mathrm{Y}$ & 0 & 28.6 & 1.744444444 & $\mu \mathrm{g} / \mathrm{L}$ & 27 \\
\hline Toluene & 699-22-35 & $\mathrm{N}$ & 0 & 0.17 & 0.0084 & $\mu \mathrm{g} / \mathrm{L}$ & 25 \\
\hline Toluene & 699-23-34B & $\mathrm{N}$ & 0 & 0.054 & 0.00216 & $\mu \mathrm{g} / \mathrm{L}$ & 25 \\
\hline Toluene & 699-24-33 & $\mathrm{N}$ & 0 & 0.058 & 0.00126087 & $\mu \mathrm{g} / \mathrm{L}$ & 46 \\
\hline Toluene & 699-24-34A & $\mathrm{N}$ & 0 & 0.9 & 0.021266667 & $\mu \mathrm{g} / \mathrm{L}$ & 45 \\
\hline Toluene & 699-24-34B & $\mathrm{N}$ & 0 & 0.061 & 0.002688889 & $\mu \mathrm{g} / \mathrm{L}$ & 45 \\
\hline Toluene & 699-24-35 & $\mathrm{N}$ & 0 & 0.08 & 0.003977273 & $\mu \mathrm{g} / \mathrm{L}$ & 44 \\
\hline Toluene & $699-25-34 \mathrm{C}$ & $\mathrm{N}$ & 0 & 0.084 & 0.002883721 & $\mu \mathrm{g} / \mathrm{L}$ & 43 \\
\hline Toluene & 699-26-35A & $\mathrm{N}$ & 0 & 0.2 & 0.005 & $\mu \mathrm{g} / \mathrm{L}$ & 40 \\
\hline Total carbon & 699-22-35 & $\mathrm{N}$ & 26800 & 105000 & 77506.81818 & $\mu \mathrm{g} / \mathrm{L}$ & 22 \\
\hline Total carbon & 699-23-34A & $\mathrm{N}$ & 23000 & 96700 & 68856.75676 & $\mu \mathrm{g} / \mathrm{L}$ & 37 \\
\hline Total carbon & 699-23-34B & $\mathrm{N}$ & 36500 & 108000 & 74615.90909 & $\mu \mathrm{g} / \mathrm{L}$ & 22 \\
\hline Total carbon & 699-24-33 & $\mathrm{N}$ & 20700 & 78150 & 60095.94595 & $\mu \mathrm{g} / \mathrm{L}$ & 37 \\
\hline Total carbon & 699-24-34A & $\mathrm{N}$ & 27300 & 89000 & 62363.88889 & $\mu \mathrm{g} / \mathrm{L}$ & 36 \\
\hline Total carbon & 699-24-34B & $\mathrm{N}$ & 24200 & 91000 & 64283.78378 & $\mu \mathrm{g} / \mathrm{L}$ & 37 \\
\hline Total carbon & 699-24-34C & $\mathrm{N}$ & 28600 & 97000 & 66143.24324 & $\mu \mathrm{g} / \mathrm{L}$ & 37 \\
\hline Total carbon & 699-24-35 & $\mathrm{N}$ & 18100 & 62450 & 43293.24324 & $\mu \mathrm{g} / \mathrm{L}$ & 37 \\
\hline Total carbon & $699-25-34 \mathrm{C}$ & $\mathrm{N}$ & 20600 & 61300 & 44688.57143 & $\mu \mathrm{g} / \mathrm{L}$ & 35 \\
\hline Total carbon & 699-26-35A & $\mathrm{N}$ & 4590 & 42300 & 31557.25 & $\mu \mathrm{g} / \mathrm{L}$ & 40 \\
\hline Total dissolved solids & $699-22-35$ & $\mathrm{~N}$ & 440000 & 582000 & 494545.4545 & $\mu \mathrm{g} / \mathrm{L}$ & 22 \\
\hline Total dissolved solids & 699-23-34A & $\mathrm{N}$ & 325000 & 668000000 & 74653785.71 & $\mu \mathrm{g} / \mathrm{L}$ & 28 \\
\hline Total dissolved solids & 699-23-34B & $\mathrm{N}$ & 304000 & 495500 & 456886.3636 & $\mu \mathrm{g} / \mathrm{L}$ & 22 \\
\hline Total dissolved solids & $699-24-33$ & $\mathrm{~N}$ & 311000 & 367000000 & 15687500 & $\mu \mathrm{g} / \mathrm{L}$ & 24 \\
\hline
\end{tabular}




\begin{tabular}{|c|c|c|c|c|c|c|c|}
\hline Constituent & Well Number & Filtered & Minimum & Maximum & Average & Units & \begin{tabular}{|c|}
$\begin{array}{c}\text { Number of } \\
\text { Samples }\end{array}$ \\
\end{tabular} \\
\hline Total dissolved solids & 699-24-34A & $\mathrm{N}$ & 351000 & 367000000 & 63211178.57 & $\mu \mathrm{g} / \mathrm{L}$ & 28 \\
\hline Total dissolved solids & 699-24-34B & $\mathrm{N}$ & 350000 & 383000000 & 65325857.14 & $\mu \mathrm{g} / \mathrm{L}$ & 28 \\
\hline Total dissolved solids & 699-24-34C & $\mathrm{N}$ & 400500 & 377000000 & 64853089.29 & $\mu \mathrm{g} / \mathrm{L}$ & 28 \\
\hline Total dissolved solids & 699-24-35 & $\mathrm{N}$ & 310000 & 295000000 & 50669017.86 & $\mu \mathrm{g} / \mathrm{L}$ & 28 \\
\hline Total dissolved solids & 699-25-34C & $\mathrm{N}$ & 332000 & 306000000 & 39015648.15 & $\mu \mathrm{g} / \mathrm{L}$ & 27 \\
\hline Total dissolved solids & 699-26-35A & $\mathrm{N}$ & 249000 & 269000000 & 39296666.67 & $\mu \mathrm{g} / \mathrm{L}$ & 27 \\
\hline Total halogens (all) & $699-22-35$ & $\mathrm{~N}$ & 19.775 & 27.21666667 & 23.49583333 & $\mu \mathrm{g} / \mathrm{L}$ & 2 \\
\hline Total halogens (all) & 699-23-34A & $\mathrm{N}$ & 8.2625 & 10.525 & 9.39375 & $\mu \mathrm{g} / \mathrm{L}$ & 2 \\
\hline Total halogens (all) & 699-23-34B & $\mathrm{N}$ & 12.15 & 22.075 & 17.1125 & $\mu \mathrm{g} / \mathrm{L}$ & 2 \\
\hline Total halogens (all) & 699-24-33 & $\mathrm{N}$ & 6.875 & 7.8875 & 7.38125 & $\mu \mathrm{g} / \mathrm{L}$ & 2 \\
\hline Total halogens (all) & 699-24-34A & $\mathrm{N}$ & 6.2 & 6.475 & 6.3375 & $\mu \mathrm{g} / \mathrm{L}$ & 2 \\
\hline Total halogens (all) & 699-24-34B & $\mathrm{N}$ & 7.3875 & 9.525 & 8.45625 & $\mu \mathrm{g} / \mathrm{L}$ & 2 \\
\hline Total halogens (all) & 699-24-34C & $\mathrm{N}$ & 6.5875 & 7.125 & 6.85625 & $\mu \mathrm{g} / \mathrm{L}$ & 2 \\
\hline Total halogens (all) & 699-24-35 & $\mathrm{N}$ & 4.2625 & 4.4 & 4.33125 & $\mu \mathrm{g} / \mathrm{L}$ & 2 \\
\hline Total halogens (all) & $699-25-34 \mathrm{C}$ & $\mathrm{N}$ & 2.65 & 4.15 & 3.4 & $\mu \mathrm{g} / \mathrm{L}$ & 2 \\
\hline Total halogens (all) & 699-26-35A & $\mathrm{N}$ & 3.2625 & 3.575 & 3.41875 & $\mu \mathrm{g} / \mathrm{L}$ & 2 \\
\hline Total organic carbon & $699-22-35$ & $\mathrm{~N}$ & 141.75 & 705.5 & 371.25 & $\mu \mathrm{g} / \mathrm{L}$ & 26 \\
\hline Total organic carbon & 699-23-34A & $\mathrm{N}$ & 110 & 1100 & 470.4215686 & $\mu \mathrm{g} / \mathrm{L}$ & 51 \\
\hline Total organic carbon & 699-23-34B & $\mathrm{N}$ & 110 & 900 & 384.6442308 & $\mu \mathrm{g} / \mathrm{L}$ & 26 \\
\hline Total organic carbon & 699-24-33 & $\mathrm{N}$ & 132.5 & 19850 & 879.5680272 & $\mu \mathrm{g} / \mathrm{L}$ & 49 \\
\hline Total organic carbon & 699-24-34A & $\mathrm{N}$ & 110 & 1750 & 482.0255102 & $\mu \mathrm{g} / \mathrm{L}$ & 49 \\
\hline Total organic carbon & 699-24-34B & $\mathrm{N}$ & 125 & 1250 & 464.625 & $\mu \mathrm{g} / \mathrm{L}$ & 50 \\
\hline Total organic carbon & 699-24-34C & $\mathrm{N}$ & 110 & 1000 & 474.9901961 & $\mu \mathrm{g} / \mathrm{L}$ & 51 \\
\hline Total organic carbon & 699-24-35 & $\mathrm{N}$ & 162.5 & 1000 & 462.9787582 & $\mu \mathrm{g} / \mathrm{L}$ & 52 \\
\hline Total organic carbon & 699-25-34C & $\mathrm{N}$ & 112.5 & 1500 & 493.82 & $\mu \mathrm{g} / \mathrm{L}$ & 50 \\
\hline Total organic carbon & 699-26-35A & $\mathrm{N}$ & 32 & 1264.5 & 486.2755102 & $\mu \mathrm{g} / \mathrm{L}$ & 49 \\
\hline Total organic halides & 699-22-35 & $\mathrm{N}$ & 6.475 & 45.625 & 22.3587 & $\mu \mathrm{g} / \mathrm{L}$ & 25 \\
\hline Total organic halides & $699-23-34 \mathrm{~A}$ & $\mathrm{~N}$ & 4.9 & 68.8 & 27.2088447 & $\mu \mathrm{g} / \mathrm{L}$ & 45 \\
\hline Total organic halides & 699-23-34B & $\mathrm{N}$ & 4.4625 & 38.95 & 19.35546875 & $\mu \mathrm{g} / \mathrm{L}$ & 24 \\
\hline Total organic halides & $699-24-33$ & $\mathrm{~N}$ & 2.65 & 62.5 & 15.72608156 & $\mu \mathrm{g} / \mathrm{L}$ & 47 \\
\hline Total organic halides & 699-24-34A & $\mathrm{N}$ & 2.4725 & 826 & 47.79841667 & $\mu \mathrm{g} / \mathrm{L}$ & 46 \\
\hline Total organic halides & 699-24-34B & $\mathrm{N}$ & 4.02 & 343.25 & 27.68011111 & $\mu \mathrm{g} / \mathrm{L}$ & 45 \\
\hline Total organic halides & 699-24-34C & $\mathrm{N}$ & 3.4075 & 673.75 & 31.82127778 & $\mu \mathrm{g} / \mathrm{L}$ & 45 \\
\hline Total organic halides & 699-24-35 & $\mathrm{N}$ & 2 & 914.5 & 37.43714692 & $\mu \mathrm{g} / \mathrm{L}$ & 44 \\
\hline Total organic halides & $699-25-34 \mathrm{C}$ & $\mathrm{N}$ & 2.65 & 17.5 & 8.724331395 & $\mu \mathrm{g} / \mathrm{L}$ & 44 \\
\hline Total organic halides & 699-26-35A & $\mathrm{N}$ & 3.0025 & 100 & 12.52895833 & $\mu \mathrm{g} / \mathrm{L}$ & 48 \\
\hline trans-1,2-Dichloroethylene & 699-24-34A & $\mathrm{N}$ & 0 & 2 & 0.0408 & $\mu \mathrm{g} / \mathrm{L}$ & 51 \\
\hline trans-1,2-Dichloroethylene & 699-24-34B & $\mathrm{N}$ & 0 & 0.23 & 0.004509804 & $\mu \mathrm{g} / \mathrm{L}$ & 52 \\
\hline trans-1,2-Dichloroethylene & 699-24-34C & $\mathrm{N}$ & 0 & 1.7 & 0.033846154 & $\mu \mathrm{g} / \mathrm{L}$ & 53 \\
\hline trans-1,2-Dichloroethylene & 699-24-35 & $\mathrm{N}$ & 0 & 0.15 & 0.002941176 & $\mu \mathrm{g} / \mathrm{L}$ & 52 \\
\hline Trichloroethene & 699-22-35 & $\mathrm{N}$ & 0.54 & 4.3 & 1.4884 & $\mu \mathrm{g} / \mathrm{L}$ & 25 \\
\hline Trichloroethene & 699-23-34A & $\mathrm{N}$ & 0 & 10 & 2.8818 & $\mu \mathrm{g} / \mathrm{L}$ & 51 \\
\hline Trichloroethene & $699-23-34 \mathrm{~B}$ & $\mathrm{~N}$ & 0.43 & 2.6 & 1.3132 & $\mu \mathrm{g} / \mathrm{L}$ & 25 \\
\hline Trichloroethene & 699-24-33 & $\mathrm{N}$ & 0 & 3 & 1.132884615 & $\mu g / L$ & 53 \\
\hline
\end{tabular}




\begin{tabular}{|c|c|c|c|c|c|c|c|}
\hline Constituent & Well Number & Filtered & Minimum & Maximum & Average & Units & $\begin{array}{c}\text { Number of } \\
\text { Samples } \\
\end{array}$ \\
\hline Trichloroethene & 699-24-34A & $\mathrm{N}$ & 0 & 7 & 1.991736111 & $\mu \mathrm{g} / \mathrm{L}$ & 49 \\
\hline Trichloroethene & 699-24-34B & $\mathrm{N}$ & 0 & 8 & 2.116122449 & $\mu \mathrm{g} / \mathrm{L}$ & 50 \\
\hline Trichloroethene & 699-24-34C & $\mathrm{N}$ & 0 & 4 & 1.3603 & $\mu \mathrm{g} / \mathrm{L}$ & 51 \\
\hline Trichloroethene & 699-24-35 & $\mathrm{N}$ & 0 & 1.1 & 0.21283 & $\mu \mathrm{g} / \mathrm{L}$ & 51 \\
\hline Trichloroethene & 699-25-34C & $\mathrm{N}$ & 0 & 3 & 0.58244898 & $\mu \mathrm{g} / \mathrm{L}$ & 50 \\
\hline Trichloroethene & 699-26-35A & $\mathrm{N}$ & 0 & 1 & 0.194390244 & $\mu \mathrm{g} / \mathrm{L}$ & 41 \\
\hline Tritium & 699-22-35 & $\mathrm{N}$ & -118 & 422 & 140.9323333 & $\mathrm{pCi} / \mathrm{L}$ & 27 \\
\hline Tritium & 699-23-34A & $\mathrm{N}$ & 206 & 158000 & 30940.55 & $\mathrm{pCi} / \mathrm{L}$ & 40 \\
\hline Tritium & 699-23-34B & $\mathrm{N}$ & -83.2 & 88400 & 3651.761538 & $\mathrm{pCi} / \mathrm{L}$ & 26 \\
\hline Tritium & 699-24-33 & $\mathrm{N}$ & 22800 & 330000 & 158478.0317 & $\mathrm{pCi} / \mathrm{L}$ & 63 \\
\hline Tritium & 699-24-34A & $\mathrm{N}$ & 2280 & 216000 & 43585.86842 & $\mathrm{pCi} / \mathrm{L}$ & 38 \\
\hline Tritium & 699-24-34B & $\mathrm{N}$ & 3770 & 301000 & 89763.925 & $\mathrm{pCi} / \mathrm{L}$ & 40 \\
\hline Tritium & 699-24-34C & $\mathrm{N}$ & -47.7 & 326000 & 138302.7075 & $\mathrm{pCi} / \mathrm{L}$ & 40 \\
\hline Tritium & \begin{tabular}{|l|}
$699-24-35$ \\
\end{tabular} & $\mathrm{~N}$ & 391 & 163000 & 29339.6575 & $\mathrm{pCi} / \mathrm{L}$ & 40 \\
\hline Tritium & 699-25-34C & $\mathrm{N}$ & 42400 & 298000 & 162755.75 & $\mathrm{pCi} / \mathrm{L}$ & 40 \\
\hline Tritium & 699-26-35A & $\mathrm{N}$ & 51800 & 297000 & 163028.75 & $\mathrm{pCi} / \mathrm{L}$ & 40 \\
\hline Turbidity & 699-22-35 & $\mathrm{N}$ & 0.47 & 4.575 & 1.343409091 & NTU & 22 \\
\hline Turbidity & \begin{tabular}{|l|}
$699-22-35$ \\
\end{tabular} & $\mathrm{Y}$ & 0.34 & \begin{tabular}{|l|}
0.59 \\
\end{tabular} & 0.4275 & NTU & 4 \\
\hline Turbidity & 699-23-34A & $\mathrm{N}$ & 0.36 & 4.09 & 1.817272727 & NTU & 22 \\
\hline Turbidity & 699-23-34A & $\mathrm{Y}$ & 0.27 & 0.74 & 0.476666667 & NTU & 3 \\
\hline Turbidity & 699-23-34B & \begin{tabular}{|l|}
$\mathrm{N}$ \\
\end{tabular} & 0.38 & 4.11 & 1.34797619 & NTU & 21 \\
\hline Turbidity & 699-23-34B & \begin{tabular}{|l|}
$Y$ \\
\end{tabular} & 0.26 & 0.81 & 0.496666667 & NTU & 3 \\
\hline Turbidity & 699-24-33 & $\mathrm{N}$ & 0.09 & 2.32 & 0.780340909 & NTU & 22 \\
\hline Turbidity & 699-24-33 & $\mathrm{Y}$ & 0.34 & 0.8 & 0.4875 & NTU & 4 \\
\hline Turbidity & 699-24-34A & $\mathrm{N}$ & 0.27 & 4.35 & 1.819801587 & NTU & 21 \\
\hline Turbidity & 699-24-34A & $\mathrm{Y}$ & 0.32 & 0.63 & 0.426666667 & NTU & 3 \\
\hline Turbidity & 699-24-34B & $\mathrm{N}$ & 0.17 & 4.17 & 1.590833333 & NTU & 21 \\
\hline Turbidity & 699-24-34B & $\mathrm{Y}$ & 0.23 & 0.57 & 0.343333333 & NTU & 3 \\
\hline Turbidity & 699-24-34C & \begin{tabular}{|l|}
$\mathrm{N}$ \\
\end{tabular} & 0.47 & 4.92 & 2.645454545 & NTU & 22 \\
\hline Turbidity & 699-24-34C & $\mathrm{Y}$ & 0.17 & 0.53 & 0.363333333 & NTU & 3 \\
\hline Turbidity & 699-24-35 & $\mathrm{N}$ & 0.57 & 4.25 & 1.811428571 & NTU & 21 \\
\hline Turbidity & 699-24-35 & $\mathrm{Y}$ & 0.13 & 0.55 & 0.31 & NTU & 4 \\
\hline Turbidity & 699-25-34C & $\mathrm{N}$ & 0.28 & 6.1 & 2.156363636 & NTU & 22 \\
\hline Turbidity & 699-25-34C & \begin{tabular}{|l|}
$\mathrm{Y}$ \\
\end{tabular} & 0.16 & 1.13 & 0.513333333 & NTU & 3 \\
\hline Turbidity & 699-26-35A & $\mathrm{N}$ & 0.1 & 1.466666667 & 0.658174603 & NTU & 21 \\
\hline Turbidity & 699-26-35A & $\mathrm{Y}$ & 0.27 & 0.36 & 0.306666667 & NTU & 3 \\
\hline Uranium & 699-24-33 & $\mathrm{N}$ & 4.329999924 & 4.329999924 & 4.329999924 & $\mu \mathrm{g} / \mathrm{L}$ & 1 \\
\hline Vanadium & \begin{tabular}{|c|}
$699-22-35$ \\
\end{tabular} & \begin{tabular}{|l|}
$\mathrm{Y}$ \\
\end{tabular} & 5.6 & 26.6 & 15.29807692 & $\mu \mathrm{g} / \mathrm{L}$ & 26 \\
\hline Vanadium & 699-23-34A & $\mathrm{N}$ & 0 & 18 & 10.53117647 & $\mu \mathrm{g} / \mathrm{L}$ & 17 \\
\hline Vanadium & 699-23-34A & $\mathrm{Y}$ & 0 & 34 & 13.15625 & $\mu \mathrm{g} / \mathrm{L}$ & 48 \\
\hline Vanadium & 699-23-34B & $\mathrm{Y}$ & 5.2 & 31 & 15.98846154 & $\mu \mathrm{g} / \mathrm{L}$ & 26 \\
\hline Vanadium & \begin{tabular}{|l|}
$699-24-33$ \\
\end{tabular} & $\mathrm{~N}$ & 0 & 17 & 11.87407407 & $\mu \mathrm{g} / \mathrm{L}$ & 9 \\
\hline Vanadium & 699-24-33 & $\mathrm{Y}$ & 0 & 35.5 & 14.79782609 & $\mu \mathrm{g} / \mathrm{L}$ & 46 \\
\hline Vanadium & 699-24-34A & $\mathrm{N}$ & 0 & 20 & 13.08 & $\mu \mathrm{g} / \mathrm{L}$ & 15 \\
\hline Vanadium & 699-24-34A & $\mathrm{Y}$ & 0 & 33.8 & 13.74021739 & $\mu \mathrm{g} / \mathrm{L}$ & 46 \\
\hline Vanadium & 699-24-34B & $\mathrm{N}$ & 0 & 19 & 12.2375 & $\mu \mathrm{g} / \mathrm{L}$ & 16 \\
\hline
\end{tabular}




\begin{tabular}{|c|c|c|c|c|c|c|c|}
\hline Constituent & Well Number & Filtered & Minimum & Maximum & Average & Units & \begin{tabular}{|c|} 
Number of \\
Samples \\
\end{tabular} \\
\hline Vanadium & 699-24-34B & $\mathrm{Y}$ & 0 & 28.8 & 13.64791667 & $\mu \mathrm{g} / \mathrm{L}$ & 48 \\
\hline Vanadium & 699-24-34C & $\mathrm{N}$ & 0 & 16 & 11.86470588 & $\mu \mathrm{g} / \mathrm{L}$ & 17 \\
\hline Vanadium & 699-24-34C & $\mathrm{Y}$ & 0 & 43.2 & 15.53979592 & $\mu \mathrm{g} / \mathrm{L}$ & 49 \\
\hline Vanadium & 699-24-35 & $\mathrm{N}$ & 0 & 24 & 16.88235294 & $\mu \mathrm{g} / \mathrm{L}$ & 17 \\
\hline Vanadium & 699-24-35 & $\mathrm{Y}$ & 0 & 660 & 30.45 & $\mu \mathrm{g} / \mathrm{L}$ & 49 \\
\hline Vanadium & 699-25-34C & $\mathrm{N}$ & 0 & 70 & 21.625 & $\mu \mathrm{g} / \mathrm{L}$ & 16 \\
\hline Vanadium & $699-25-34 \mathrm{C}$ & $\mathrm{Y}$ & 0 & 41 & 17.14166667 & $\mu \mathrm{g} / \mathrm{L}$ & 48 \\
\hline Vanadium & 699-26-35A & $\mathrm{N}$ & 0 & 26 & 15.78571429 & $\mu \mathrm{g} / \mathrm{L}$ & 14 \\
\hline Vanadium & 699-26-35A & $\mathrm{Y}$ & 0 & 36.6 & 19.61707317 & $\mu \mathrm{g} / \mathrm{L}$ & 41 \\
\hline Vinyl chloride & 699-22-35 & $\mathrm{N}$ & 0 & 1.8 & 0.1008 & $\mu \mathrm{g} / \mathrm{L}$ & 25 \\
\hline Vinyl chloride & 699-23-34B & $\mathrm{N}$ & 0 & 1.5 & 0.06 & $\mu \mathrm{g} / \mathrm{L}$ & 25 \\
\hline Vinyl chloride & 699-24-35 & $\mathrm{N}$ & 0 & 0.37 & 0.0074 & $\mu \mathrm{g} / \mathrm{L}$ & 51 \\
\hline Xylenes (total) & 699-22-35 & $\mathrm{N}$ & 0 & 0.58 & 0.051 & $\mu \mathrm{g} / \mathrm{L}$ & 20 \\
\hline Xylenes (total) & 699-23-34B & $\mathrm{N}$ & 0 & 0.039 & 0.00195 & $\mu \mathrm{g} / \mathrm{L}$ & 20 \\
\hline Xylenes (total) & 699-24-33 & $\mathrm{N}$ & 0 & 0.07 & 0.001627907 & $\mu \mathrm{g} / \mathrm{L}$ & 43 \\
\hline Xylenes (total) & 699-24-34A & $\mathrm{N}$ & 0 & 0.22 & 0.0055 & $\mu \mathrm{g} / \mathrm{L}$ & 40 \\
\hline Xylenes (total) & 699-26-35A & $\mathrm{N}$ & 0 & 0.22 & 0.006470588 & $\mu \mathrm{g} / \mathrm{L}$ & 34 \\
\hline Zinc & 699-22-35 & $\mathrm{Y}$ & 0 & 48.6 & 9.234615385 & $\mu \mathrm{g} / \mathrm{L}$ & 26 \\
\hline Zinc & 699-23-34A & $\mathrm{N}$ & 0 & 64 & 18.58352941 & $\mu \mathrm{g} / \mathrm{L}$ & 17 \\
\hline Zinc & 699-23-34A & $\mathrm{Y}$ & 0 & 37 & 8.764583333 & $\mu \mathrm{g} / \mathrm{L}$ & 48 \\
\hline Zinc & 699-23-34B & $\mathrm{Y}$ & 0 & 310 & 20.7 & $\mu \mathrm{g} / \mathrm{L}$ & 26 \\
\hline Zinc & 699-24-33 & $\mathrm{N}$ & 0 & 10 & 2.69 & $\mu \mathrm{g} / \mathrm{L}$ & 8 \\
\hline Zinc & 699-24-33 & $\mathrm{Y}$ & 0 & 77.6 & 11.81956522 & $\mu \mathrm{g} / \mathrm{L}$ & 46 \\
\hline Zinc & 699-24-34A & $\mathrm{N}$ & 0 & 95 & 29.44 & $\mu \mathrm{g} / \mathrm{L}$ & 15 \\
\hline Zinc & 699-24-34A & $\mathrm{Y}$ & 0 & 234 & 14.74456522 & $\mu \mathrm{g} / \mathrm{L}$ & 46 \\
\hline Zinc & 699-24-34B & $\mathrm{N}$ & 0 & 62 & 14.83125 & $\mu \mathrm{g} / \mathrm{L}$ & 16 \\
\hline Zinc & 699-24-34B & $\mathrm{Y}$ & 0 & 315 & 19.60416667 & $\mu \mathrm{g} / \mathrm{L}$ & 48 \\
\hline Zinc & 699-24-34C & $\mathrm{N}$ & 12.4 & 130 & 49.02352941 & $\mu \mathrm{g} / \mathrm{L}$ & 17 \\
\hline Zinc & 699-24-34C & $\mathrm{Y}$ & 0 & 188 & 27.53571429 & $\mu \mathrm{g} / \mathrm{L}$ & 49 \\
\hline Zinc & 699-24-35 & $\mathrm{N}$ & 0 & 43 & 10.70588235 & $\mu \mathrm{g} / \mathrm{L}$ & 17 \\
\hline Zinc & $699-24-35$ & $\mathrm{Y}$ & 0 & 880 & 25.76632653 & $\mu \mathrm{g} / \mathrm{L}$ & 49 \\
\hline Zinc & 699-25-34C & $\mathrm{N}$ & 0 & 455 & 49.25 & $\mu \mathrm{g} / \mathrm{L}$ & 16 \\
\hline Zinc & 699-25-34C & $\mathrm{Y}$ & 0 & 49 & 11.31145833 & $\mu \mathrm{g} / \mathrm{L}$ & 48 \\
\hline Zinc & 699-26-35A & $\mathrm{N}$ & 0 & 17 & 3.857142857 & $\mu \mathrm{g} / \mathrm{L}$ & 14 \\
\hline Zinc & 699-26-35A & $\mathrm{Y}$ & 0 & 53 & 7.490243902 & $\mu \mathrm{g} / \mathrm{L}$ & 41 \\
\hline Zinc-65 & 699-24-33 & $\mathrm{N}$ & -17.60000038 & 13.60000038 & -3.014999986 & $\mathrm{pCi} / \mathrm{L}$ & 4 \\
\hline Zirconium/Niobium-95 & 699-24-33 & $\mathrm{N}$ & -32 & 3.559999943 & -5.695000052 & $\mathrm{pCi} / \mathrm{L}$ & 4 \\
\hline \multicolumn{8}{|c|}{$\begin{array}{l}\text { 1. Data are since } 1986 \text { for SWL network wells. } \\
\text { 2. Units converted to } \mu \mathrm{g} / \mathrm{L} \text {. } \\
\text { 3. Non-detects changed to } 0.0 \text {. } \\
\text { 4. Duplicate values on same date are a veraged. } \\
\text { 5. Constituents for SWL wells are listed only whe }\end{array}$} \\
\hline
\end{tabular}




\section{Appendix C}

Construction Details of the Wells in the Monitoring Network 
WELL CONSTRUCTION AND COMPLETION SUMMARY

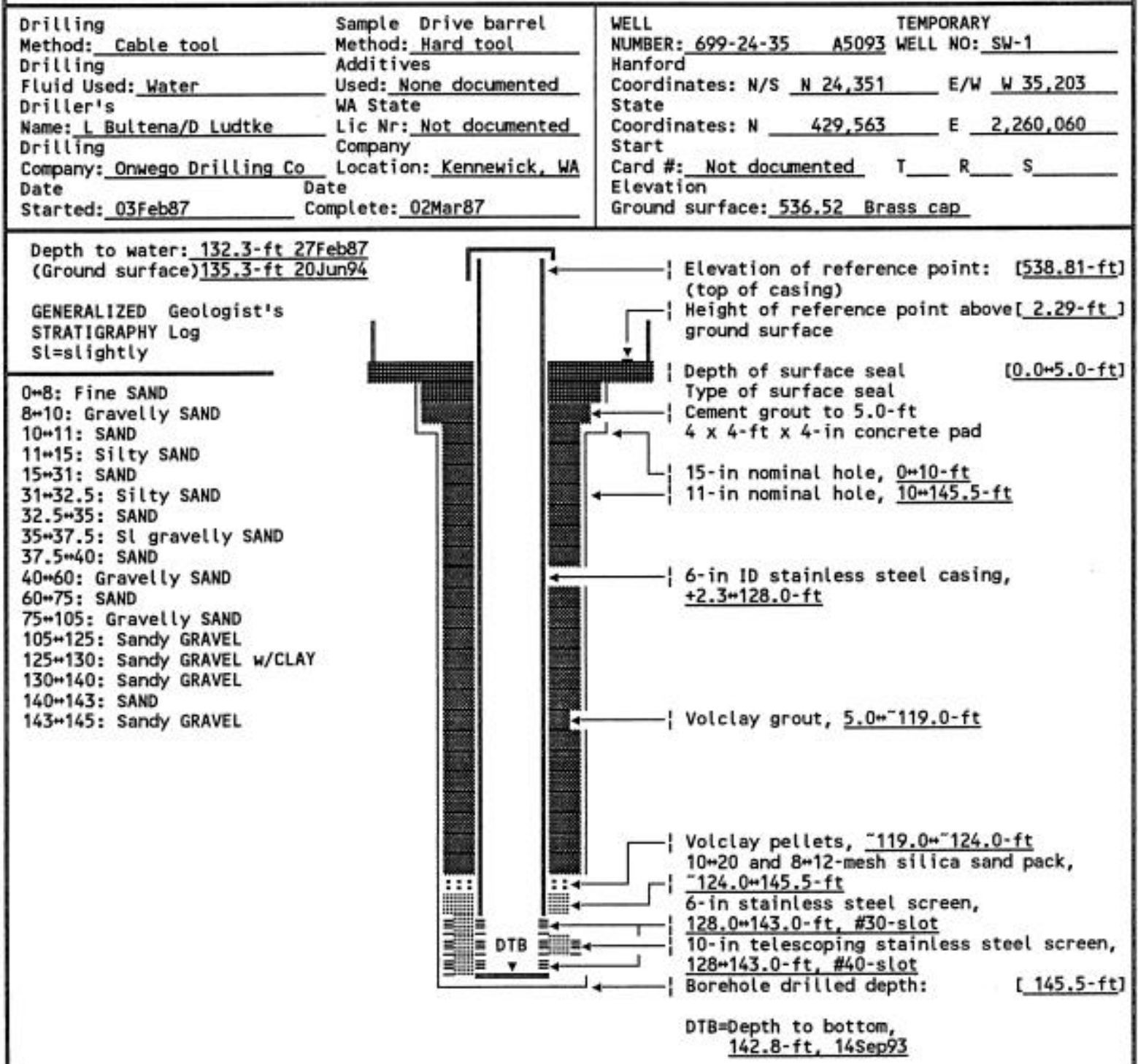

Drawing By: RKL/6N24W35.ASB

Date : $14 \operatorname{Sep} 94$

Reference : HAMFORD WELLS 


\section{SUMMARY OF CONSTRUCTION DATA AND FIELD OBSERVATIONS \\ RESOURCE PROTECTION WELL - 699-24-35}

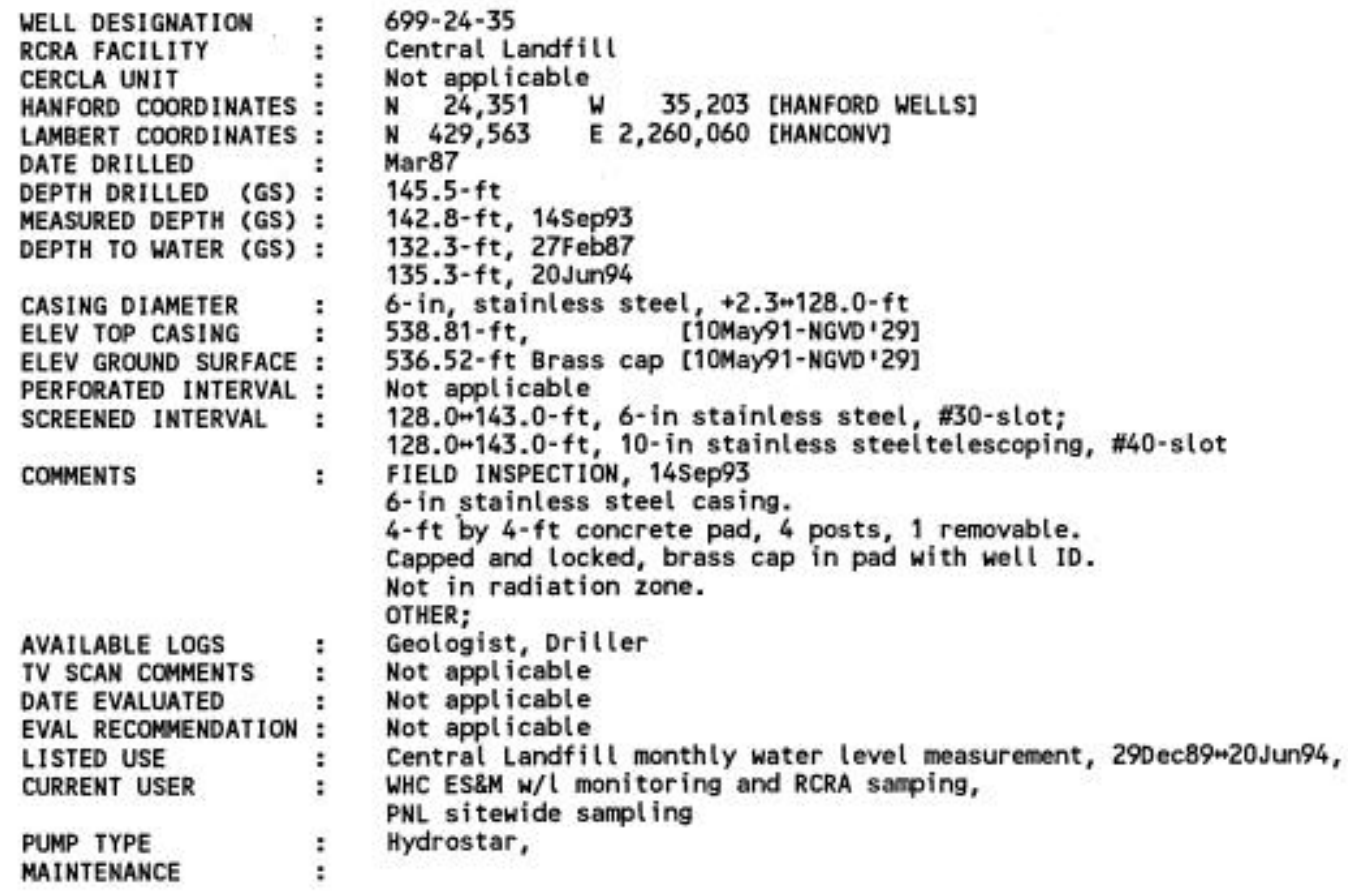




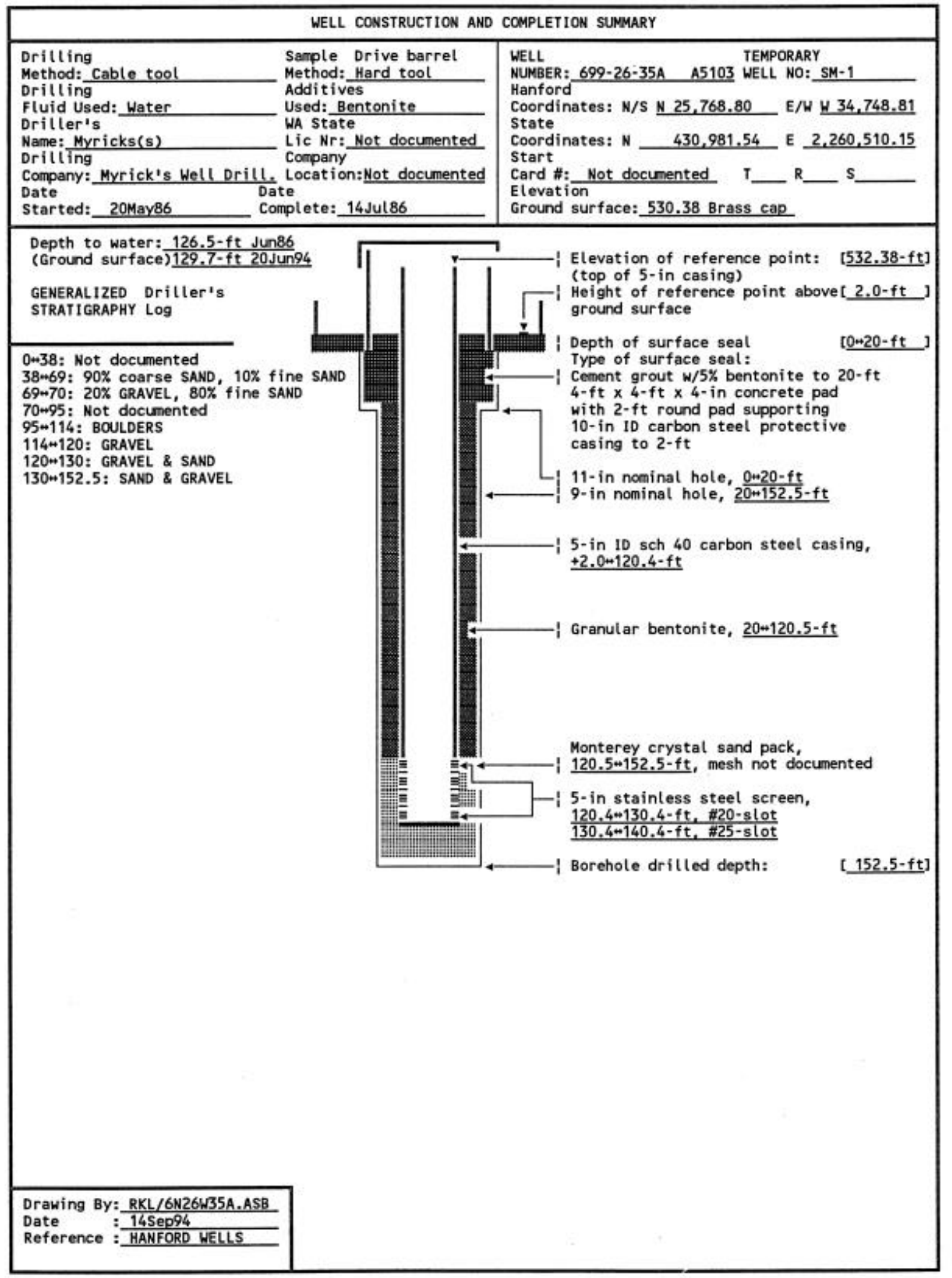




\section{SUMMARY OF CONSTRUCTION DATA AND FIELD OBSERVATIONS RESOURCE PROTECTION WELL - 699-26-35A}

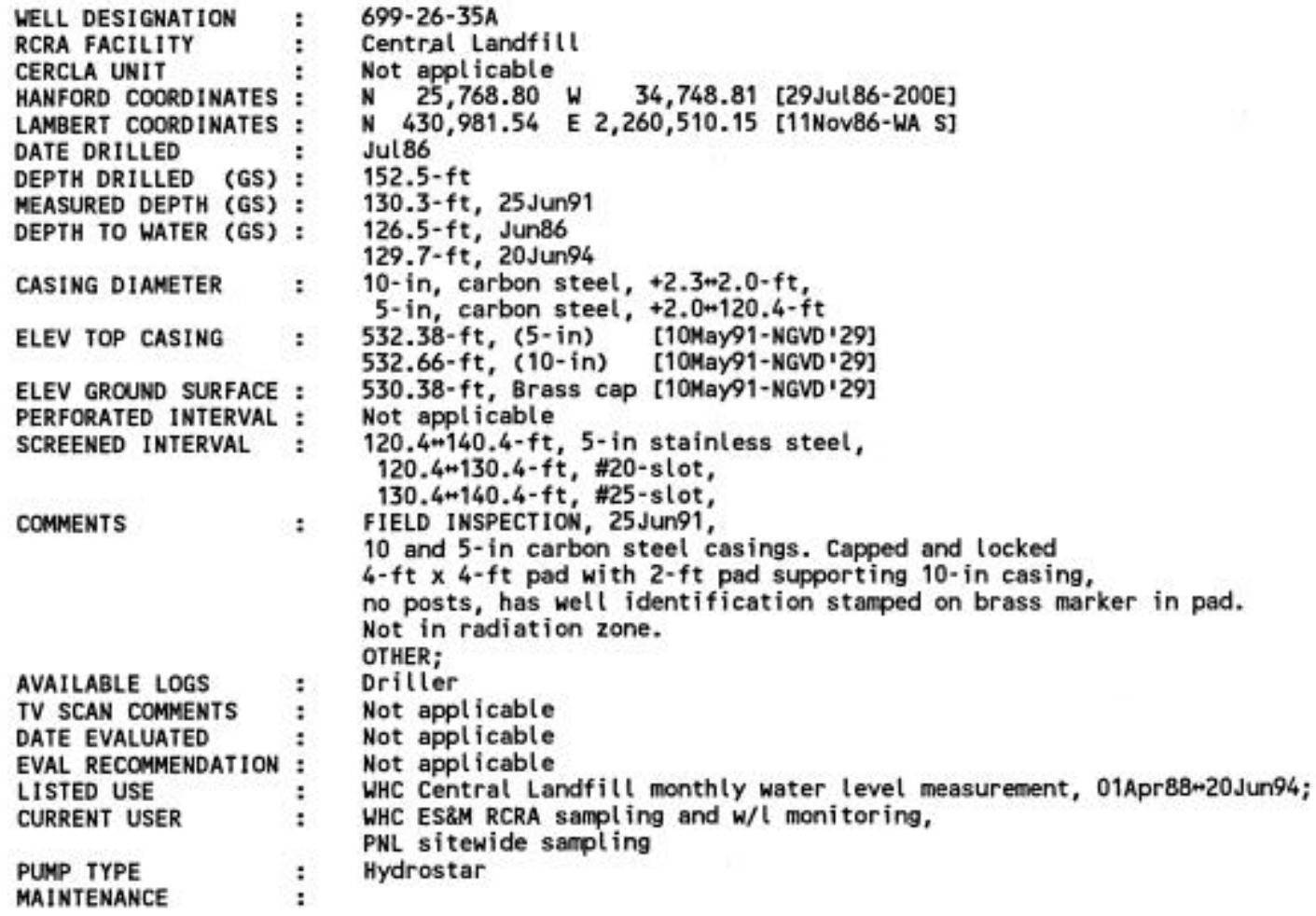




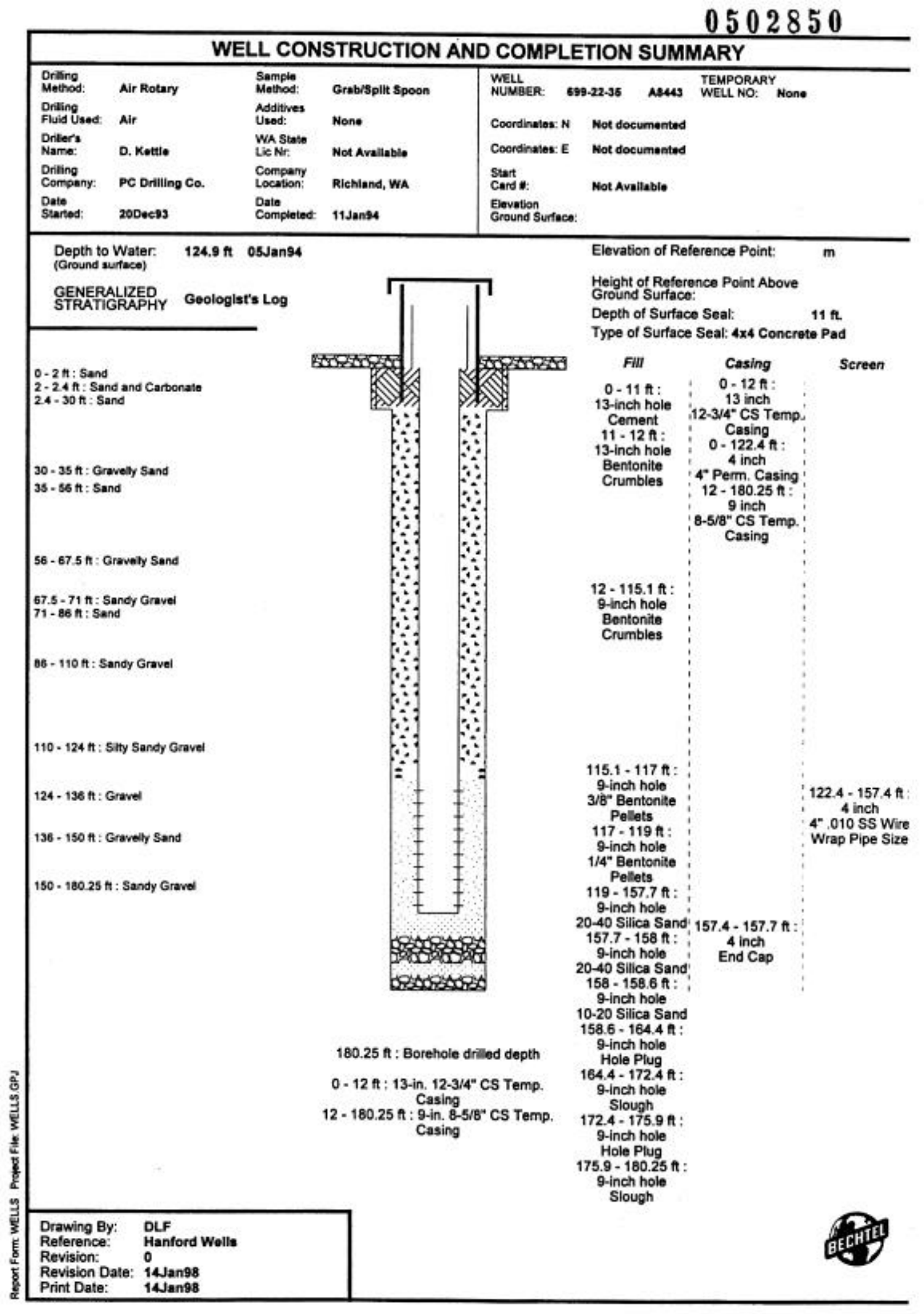

C. 5 


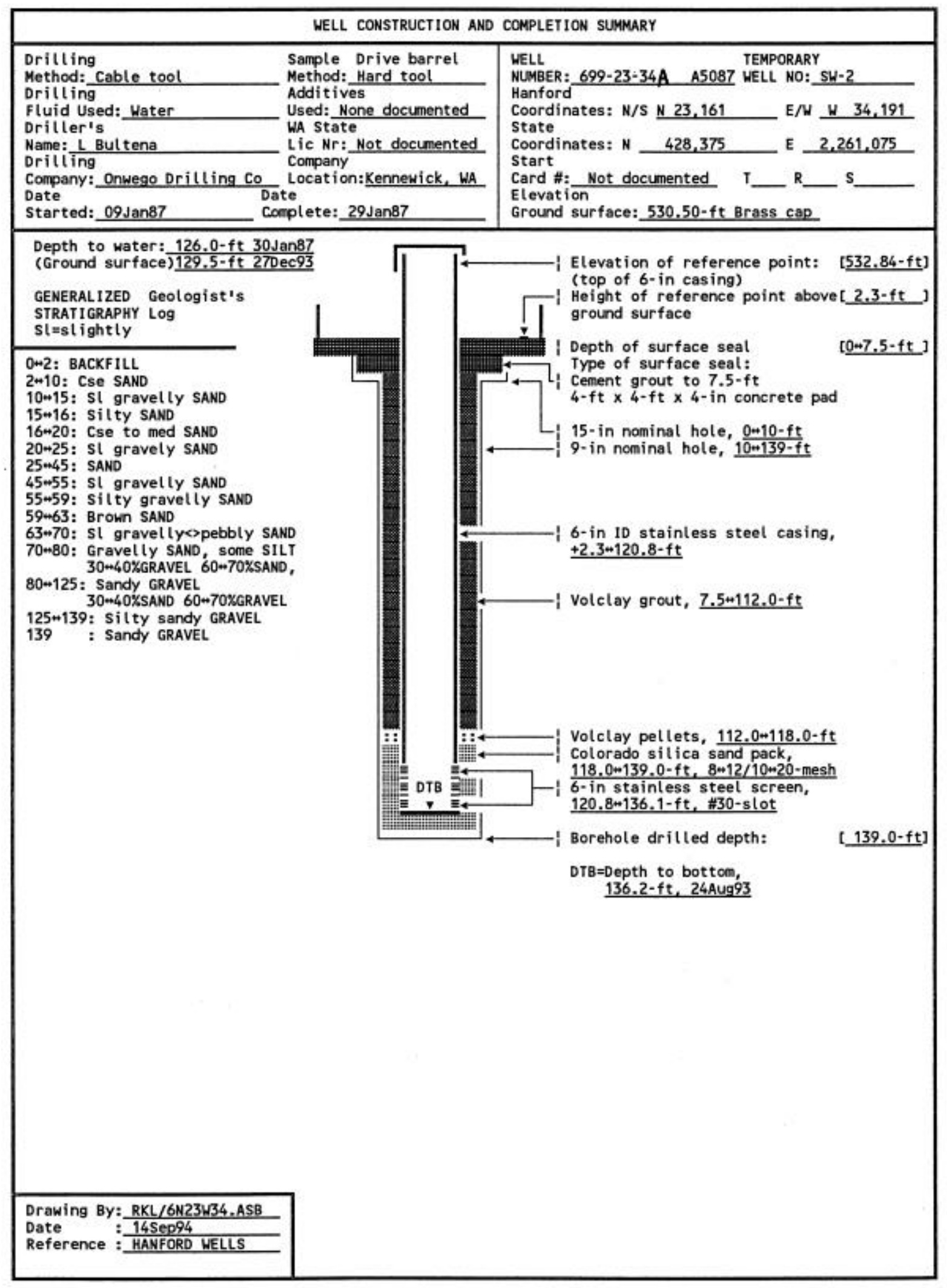




\section{SUMMARY OF CONSTRUCTION DATA AND FIELD OBSERVATIONS RESOURCE PROTECTION WELL - 699-23-34A}

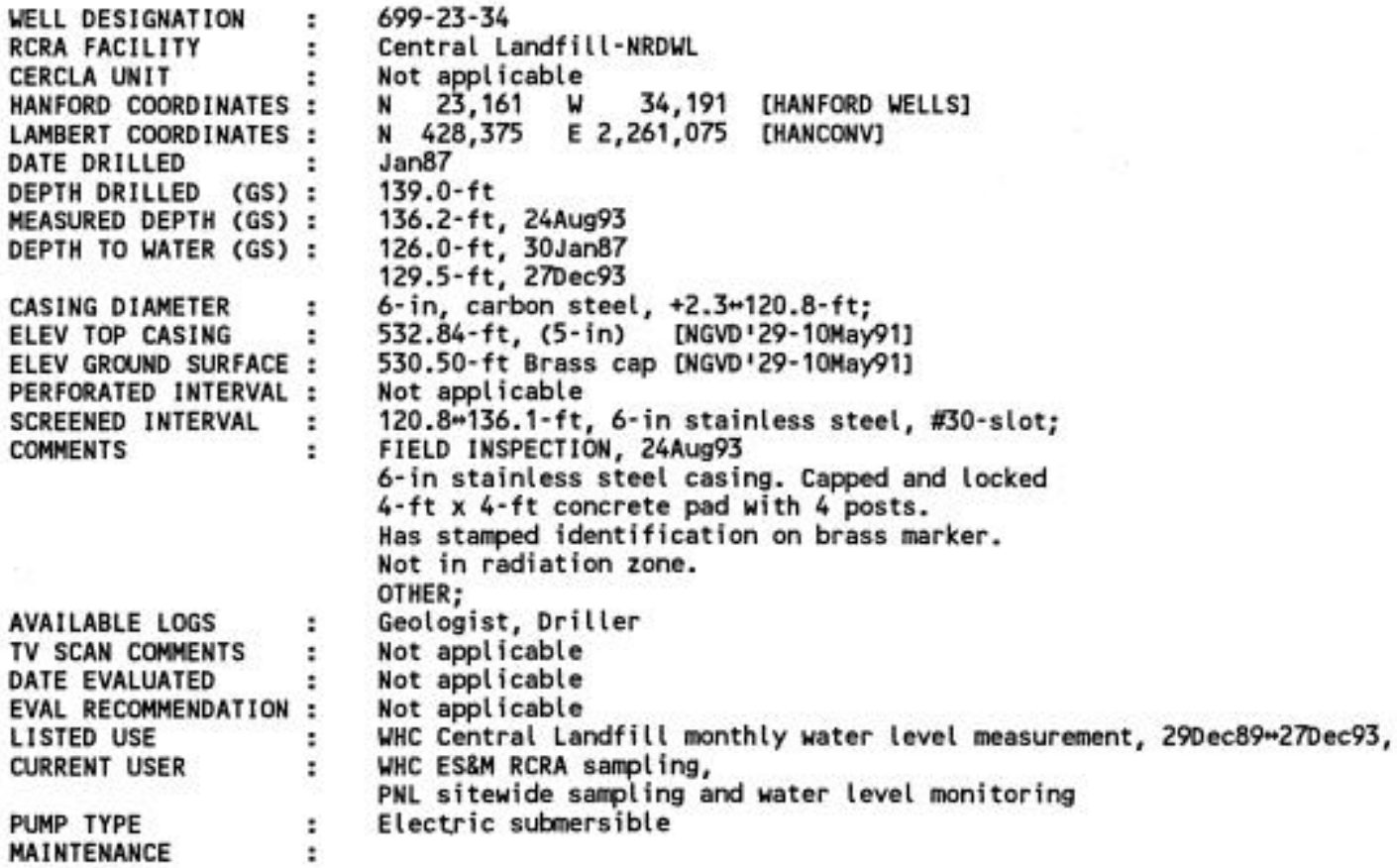




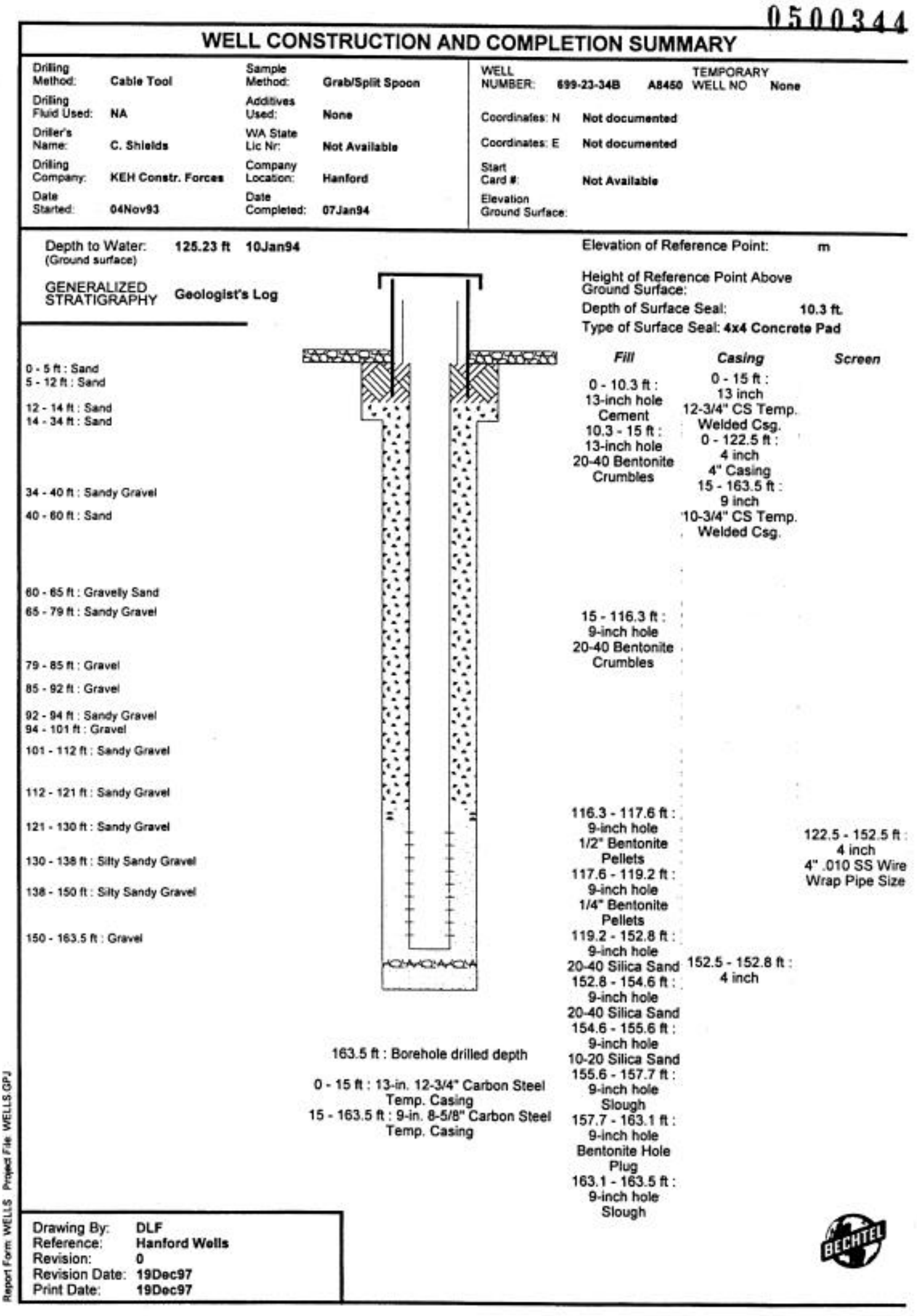

C. 8 


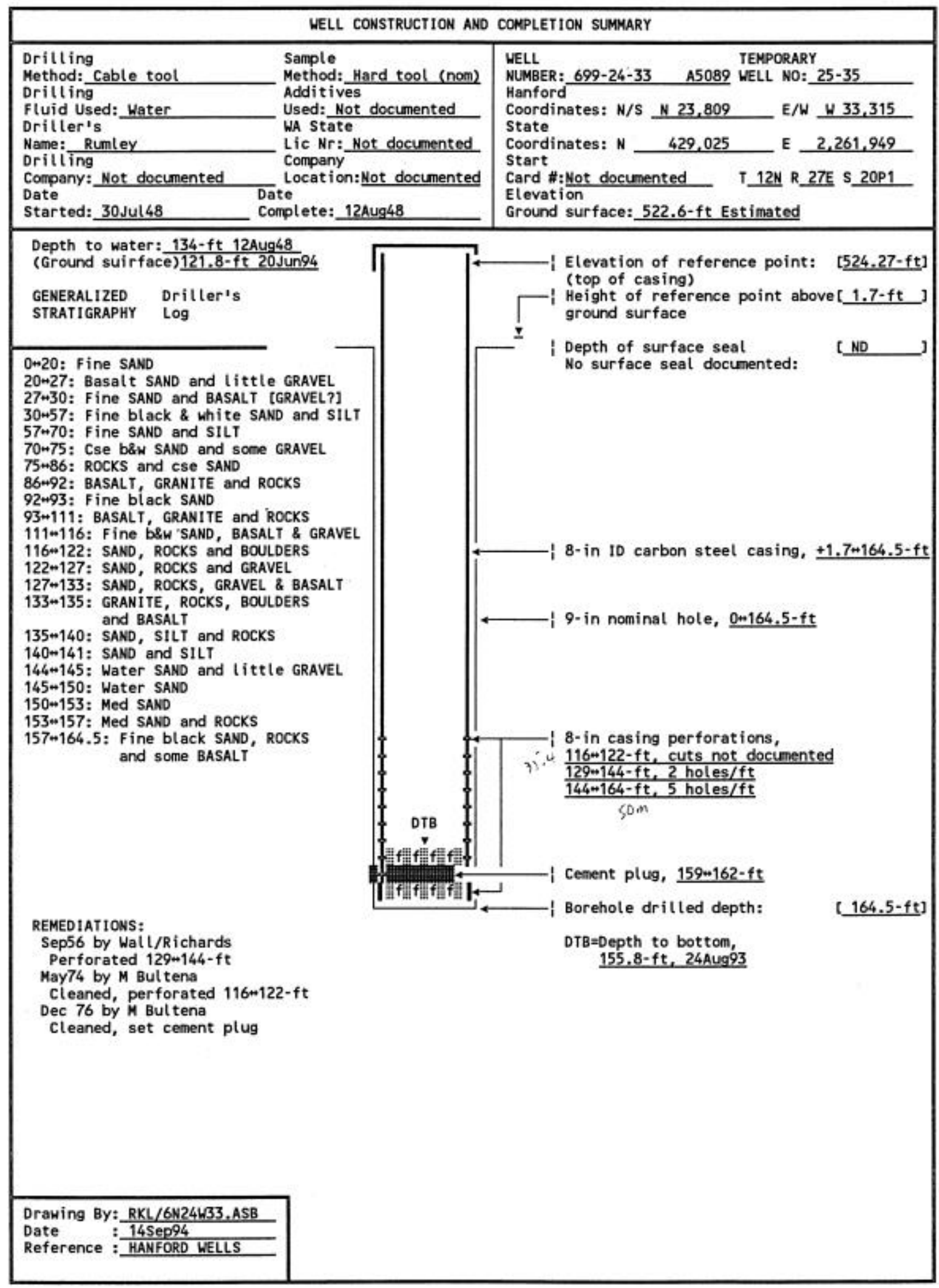




\section{SUMMARY OF CONSTRUCTION DATA AND FIELD OBSERVATIONS RESOURCE PROTECTION WELL - 699-24-33}

\begin{tabular}{l} 
WELL DESIGNATION \\
RCRA FACILITY \\
CERCLA UNIT \\
HANFORD COORD INATES \\
LAMBERT COORDINATES \\
DATE DRILLED \\
DEPTH DRILLED (GS) \\
MEASURED DEPTH (GS) \\
DEPTH TO HATER (GS) \\
CASING DIAMETER \\
ELEV TOP CASING \\
ELEV GROUND SURFACE \\
PERFORATED INTERVAL \\
SCREENED INTERVAL \\
COMMENTS \\
\multicolumn{2}{c}{} \\
AVAILABLE LOGS \\
TV SCAN COMMENTS \\
DATE EVALUATED \\
EVAL RECOMMENDATION \\
LISTED USE \\
CURRENT USER \\
PUMP TYPE \\
MAINTENANCE
\end{tabular}

699-24-33

Central landfill

Not appl icable

N 23,809 W 33,315 [HANFORD WELLS]

N 429,025 E 2,261,949 [HANCONV]

Aug 48

$164.5-\mathrm{ft}$

155.8-ft, 24Aug93

134- $\mathrm{ft}$, Aug48

121.8-ft, 20Jung4

8-in, carbon steel, $+1.7+164.5-\mathrm{ft}$

$524.27-\mathrm{ft}$ [10May91-NGVD'29]

$522.6-\mathrm{ft}$, Estimated

$116+164-\mathrm{ft}$

Not appl icable

FIELO INSPECTION, 24 AUg93

8-in carbon steel casing. Capped and locked

No pad, posts or permanent identification.

Not in radiation zone.

OTHER;

Driller

Not applicable

Not applicable

Not appl icable

Central landfill monthly level measurement, 01Jun84*20Jun94;

WHC ES\&M $w / L$ monitoring and RCRA sampling,

PNL sitewide sampling and $w / l$ monitoring

Electric submersible 


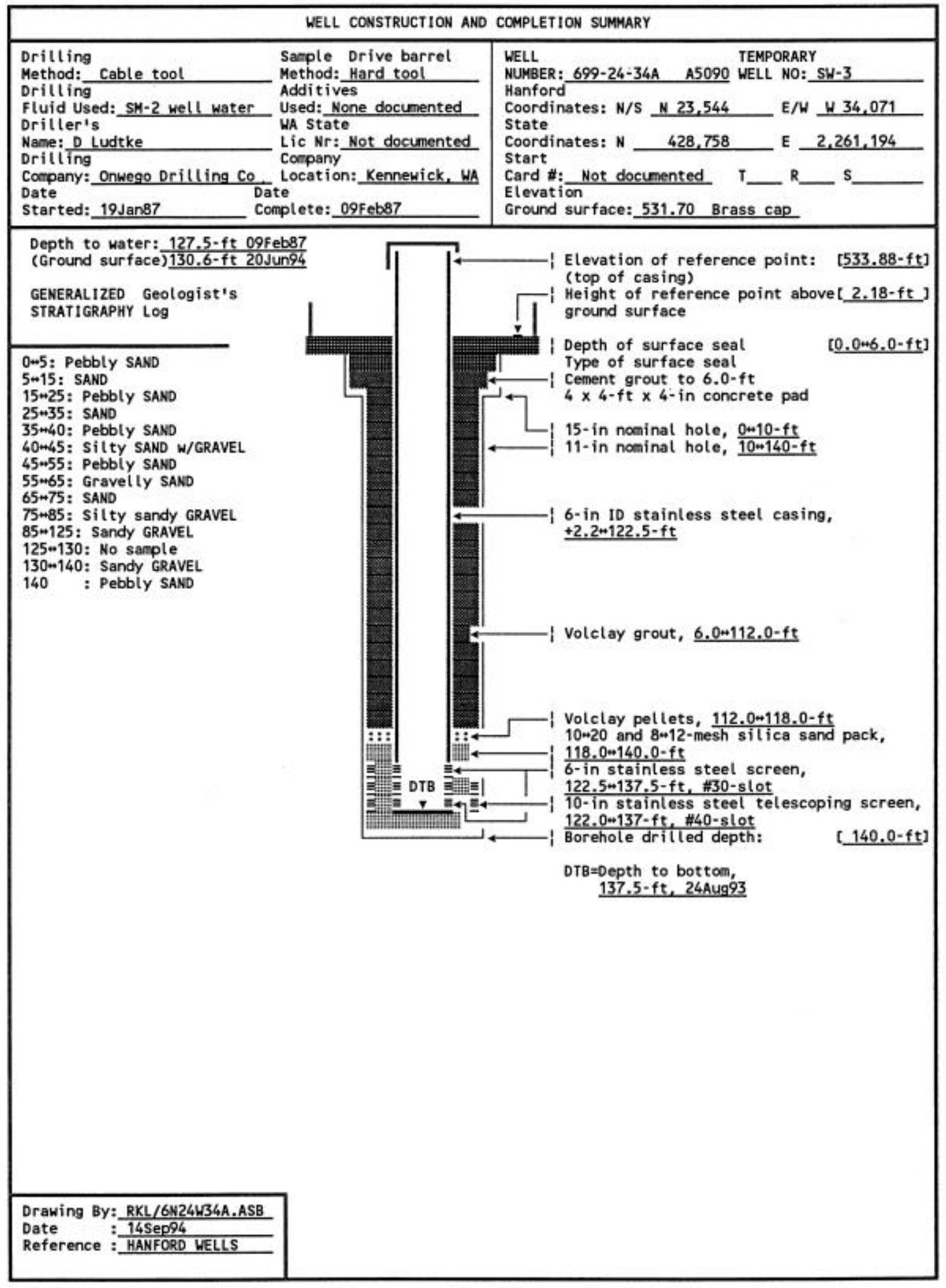




\section{SUMMARY OF CONSTRUCTION DATA AND FIELD OBSERVATIONS RESOURCE PROTECTION WELL - 699-24-34A}

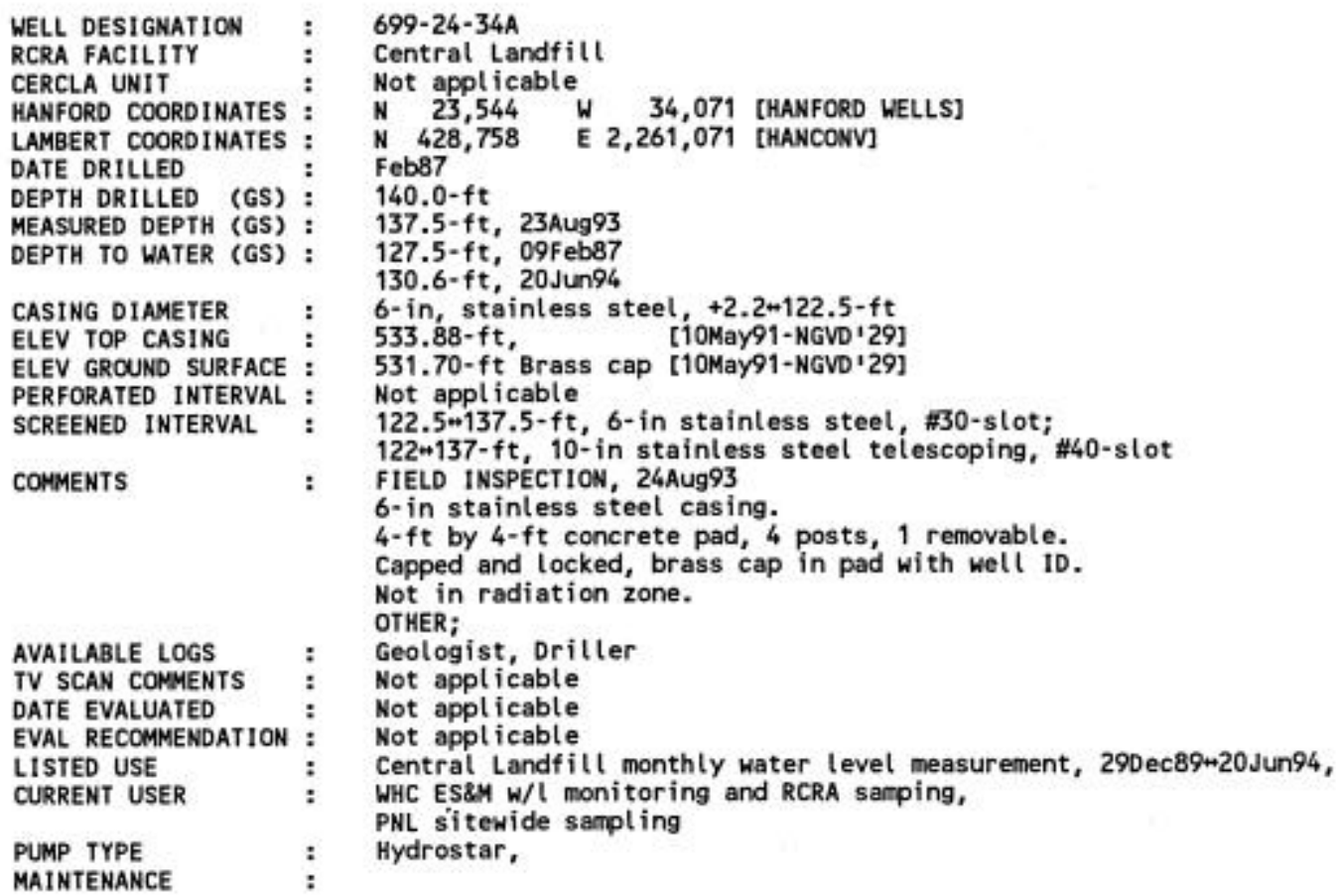




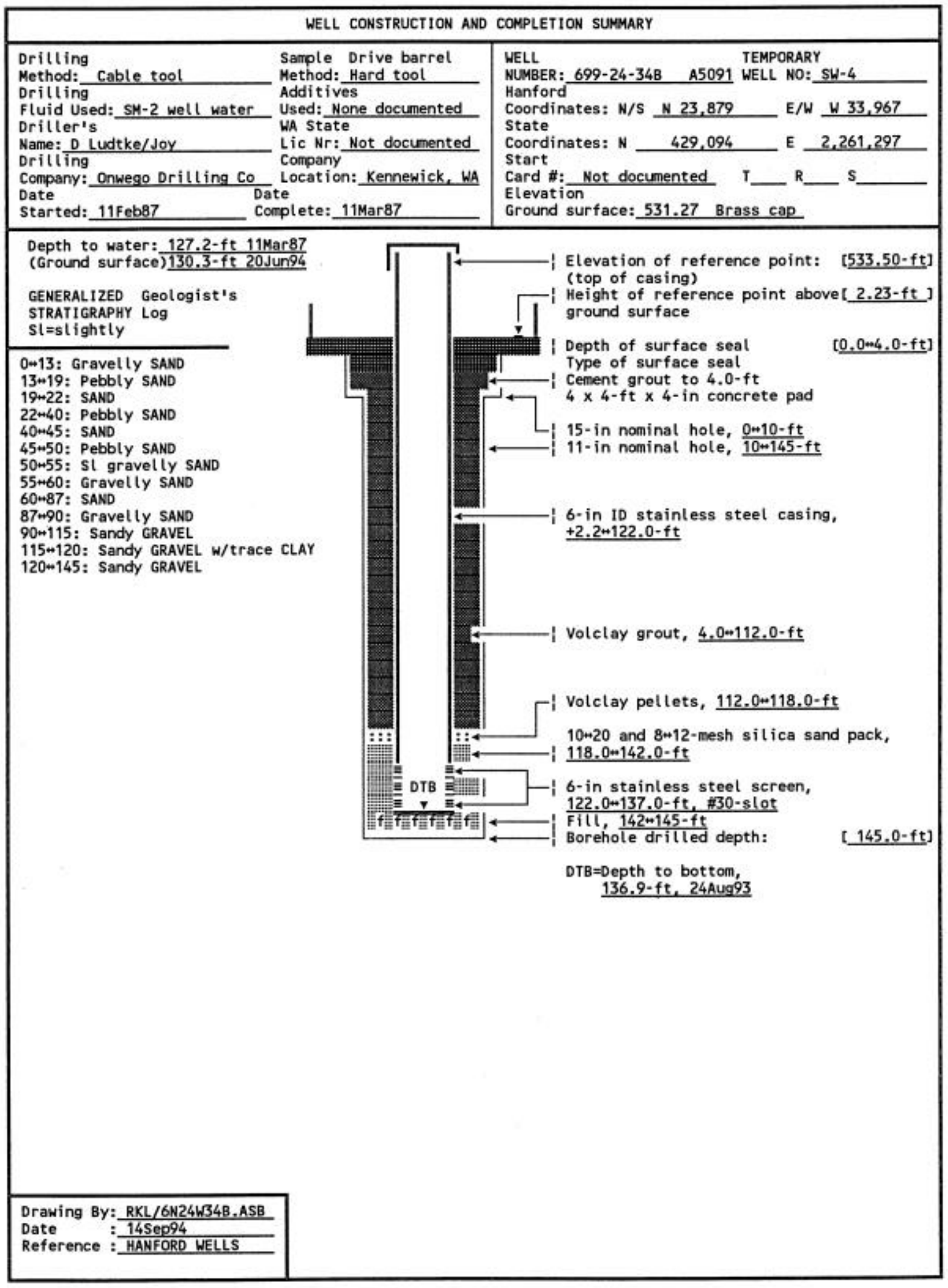

C. 13 


\section{SUMMARY OF CONSTRUCTION DATA AND FIELD OBSERVATIONS \\ RESOURCE PROTECTION WELL - 699-24-34B}

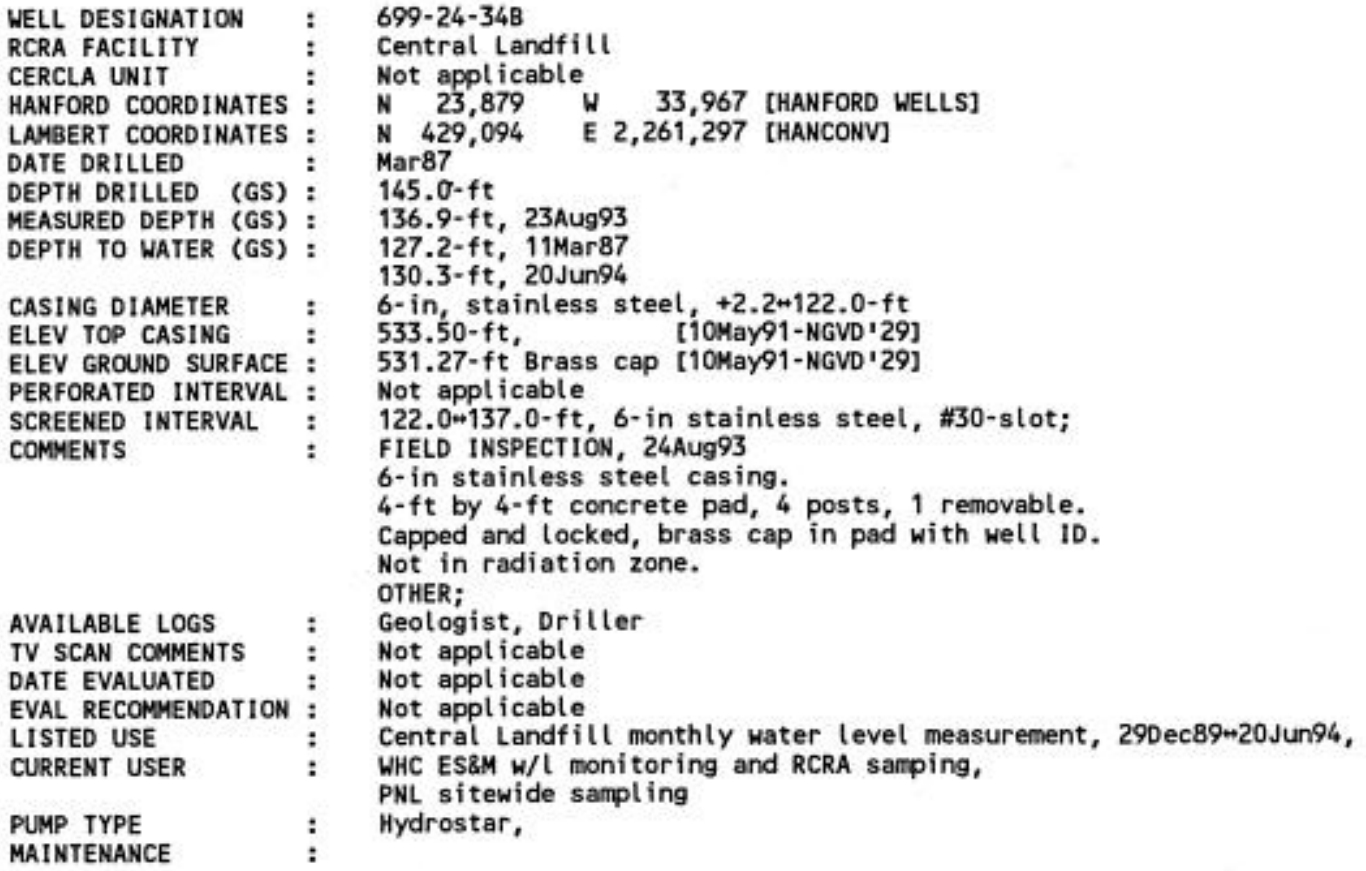




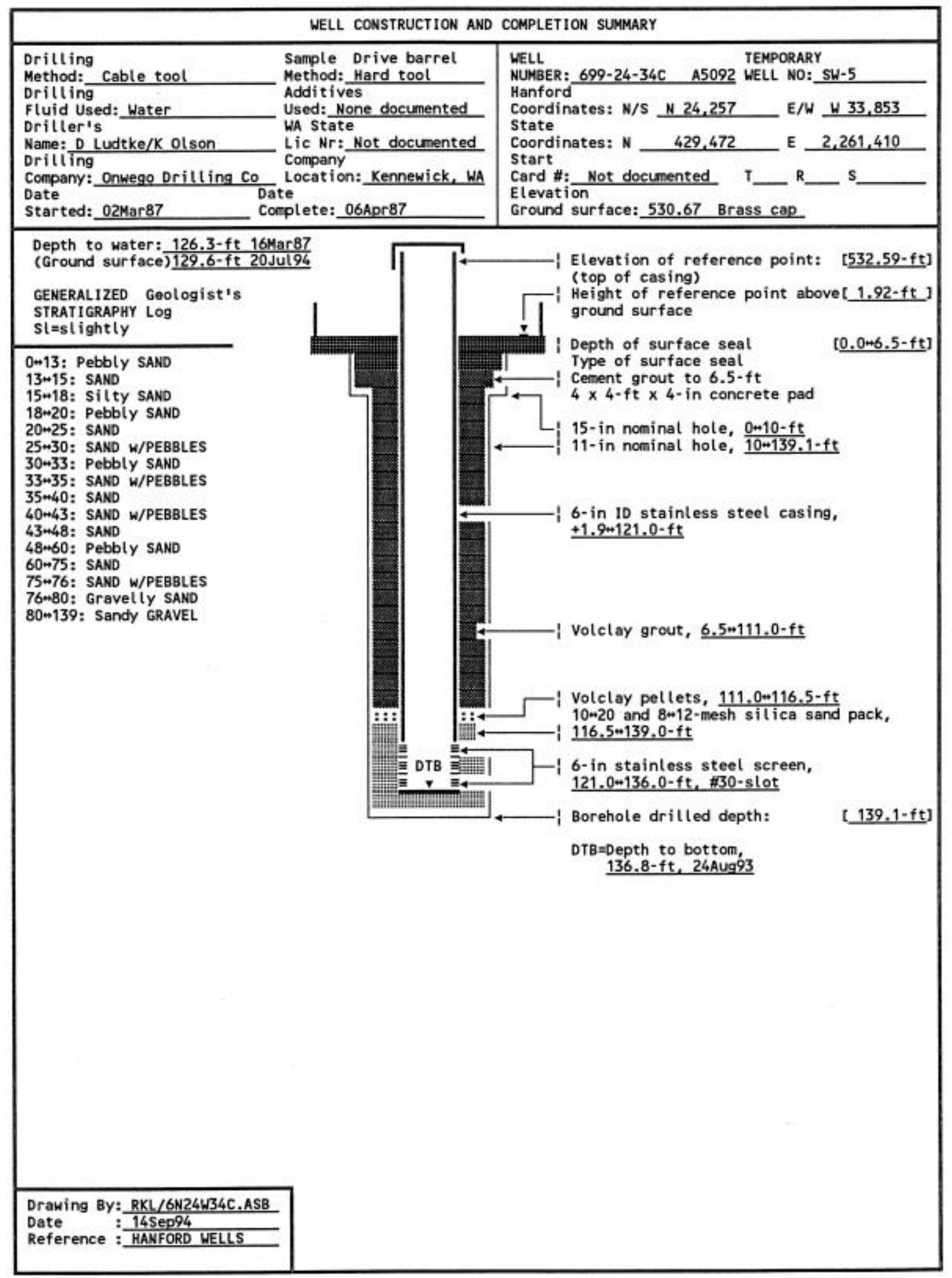




\section{SUMMARY OF CONSTRUCTION DATA AND FIELD OBSERVATIONS RESOURCE PROTECTION WELL - 699-24-34C}

\begin{tabular}{l} 
WELL DESIGNATION \\
RCRA FACILITY \\
CERCLA UNIT \\
HANFORD COORDINATES \\
LAMBERT COORDINATES \\
DATE DRILLED \\
DEPTH DRILLED (GS) \\
MEASURED DEPTH (GS) \\
DEPTH TO WATER (GS) \\
CASING DIAMETER \\
ELEV TOP CASING \\
ELEV GROUND SURFACE \\
PERFORATED INTERVAL \\
SCREENED INTERVAL \\
COMMENTS \\
\multicolumn{2}{c}{} \\
AVAILABLE LOGS \\
TV SCAN CONMENTS \\
DATE EVALUATED \\
EVAL RECOMMENDATION \\
LISTED USE \\
CURRENT USER \\
PUMP TYPE \\
MAINTENANCE
\end{tabular}

699-24-34C

Central Landfill

Not applicable

N 24,257 W 33,853 [HANFORD WELLS]

N 429,472 E $2,261,410$ [HANCONV]

Apr 87

139.1- $\mathrm{ft}$

136.8- $\mathrm{ft}, 24$ Aug 93

$126.3-\mathrm{ft}, 16 \mathrm{Mar} 87$

129.6- $\mathrm{ft}$, 20Jun94

$6-$ in, stainless steel, $+1.9=121.0-\mathrm{ft}$

$532.59-\mathrm{ft}$ [10May91-NGVD'29]

530.67-ft Brass cap [10May91-NGVD '29]

Not applicable

$121.0 m 136.0-\mathrm{ft}, 6$-in stainless steel, $\# 30$-slot;

FIELD. INSPECTION, 24 Aug93

6-in stainless steel casing.

$4-\mathrm{ft}$ by $4-\mathrm{ft}$ concrete pad, 4 posts, 1 removable.

Capped and locked, brass cap in pad with well ID.

Not in radiation zone.

OTHER;

Geologist, Driller

Not applicable

Not applicable

Not applicable

Central Landfill monthly water level measurement, 290ec89m20 Jun94, WHC ESBM $w / l$ monitoring and RCRA samping,

PNL sitewide sampling

Hydrostar, 


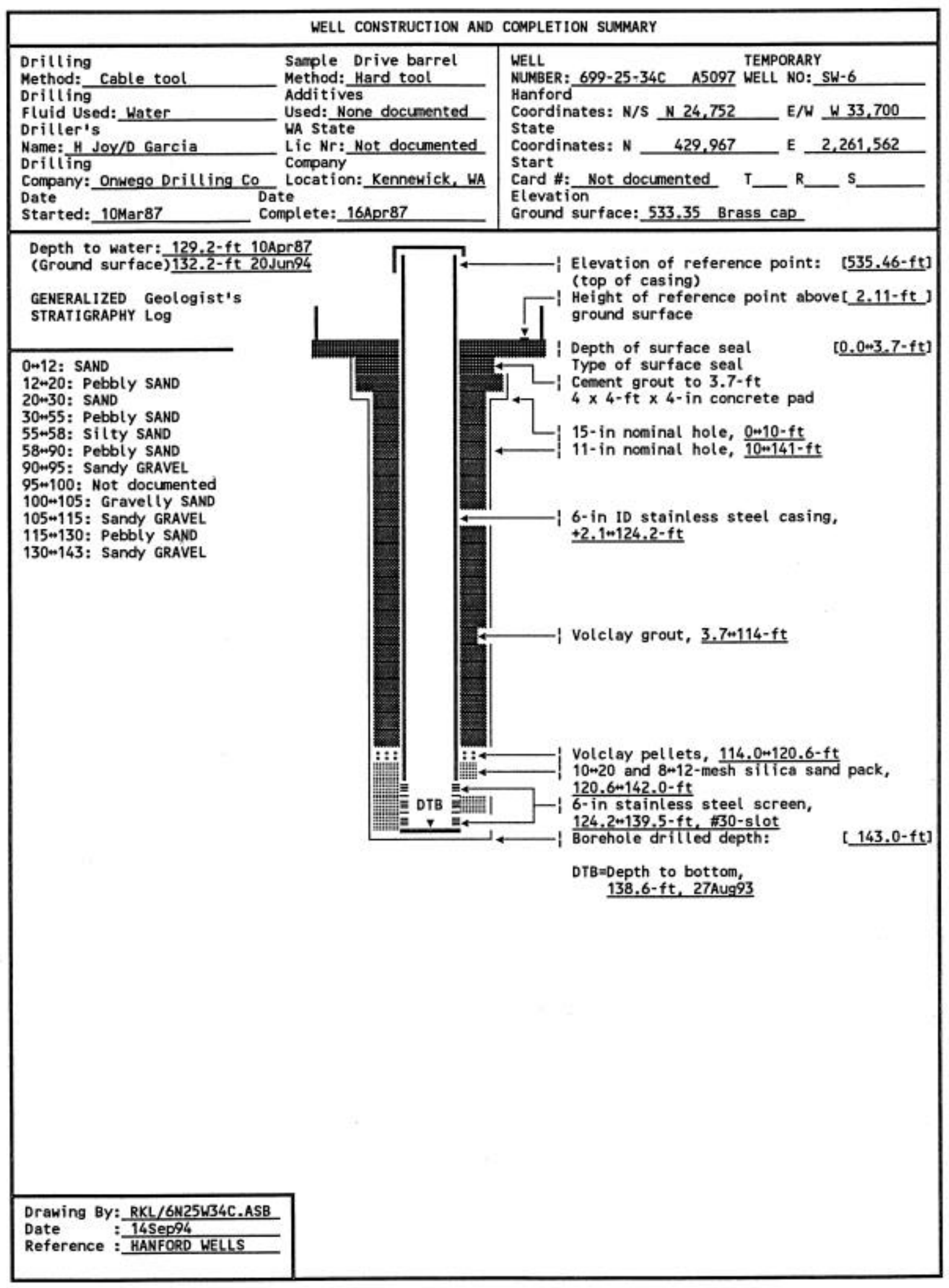

C. 17 


\section{SUMMARY OF CONSTRUCTION DATA AND FIELD OBSERVATIONS RESOURCE PROTECTION WELL - 699-25-34C}

WELL DESIGNATION
RCRA FACILITY
CERCLA UNIT
HANFORD COORDINATES :
LAMBERT COORDINATES :
DATE DRILLED
DEPTH DRILLED (GS)
MEASURED DEPTH (GS)
DEPTH TO WATER (GS)
CASING DIAMETER
ELEV TOP CASING
ELEV GROUND SURFACE :
PERFORATED INTERVAL
SCREENED INTERVAL
COMMENTS
:
AVAILABLE LOGS
TV SCAN COMMENTS
DATE EVALUATED
EVAL RECOMMENDATION
LISTED USE
CURRENT USER
PUMP TYPE
MAINTENANCE

699-25-34C

Central Landfill

Not applicable

N 24,752 W 33,700 [HANFORD WELLS]

N 429,967 E 2,261,562 [HANCONV]

Apr87

$143.0-\mathrm{ft}$

138.6- $\mathrm{ft}, 23 \mathrm{Aug} 93$

129.2-ft, 10Apr87

132.2- $\mathrm{ft}, 20 \mathrm{Jun} 94$

6-in, stainless steel, $+2 \cdot 1+124.2-\mathrm{ft}$

535.46- $\mathrm{ft}$, [10May91-NGVD'29]

$533.35-\mathrm{ft}$ Brass cap [10May91-NGVD '29]

Not applicable

$124.2+139.5-\mathrm{ft}, 6-$ in stainless steel, $\# 30-$ slot;

FIELD INSPECTION, 27 Aug93

6-in stainless steel casing.

4- $\mathrm{ft}$ by $4-\mathrm{ft}$ concrete pad, 4 posts, 1 removable.

Capped and locked, brass cap in pad with well ID.

Not in radiation zone.

OTHER;

Geologist, Driller

Not applícable

Not applicable

Not applicable

Central Landfill monthly water level measurement, 290ec89+20Jun94, WHC ES\&M $\mathrm{w} / \mathrm{l}$ monitoring and RCRA samping,

Hydrostar, 


\section{Distribution}

No. of

Copies

ONSITE

5 DOE Richland Operations Office

M. J. Furman

K. M. Thompson

A. C. Tortoso

Reading Room (2)

2 Environmental Protection Agency

D. A. Faulk

M. L. Goldstein

DynCorp, Tri-Cities, Inc.
No. of

Copies

3 Washington State Department of Ecology

D. Goswami

B5-18

A. D. Huckaby

B5-18

W. W. Soper

B5-18

A5-13

A5-13

$\mathrm{H} 0-12$

A5-13

R. A. Del Mar
B5-01

B5-01

G3-26

\section{Pacific Northwest National Laboratory}

\section{J. Chou}

K6-81

M. J. Hartman

K6-96

J. W. Lindberg (5)

K6-81

S. P. Luttrell

K6-96

L. F. Morasch

K6-86

D. Vela (Project File)

K6-96

Information Release Office (7)
K1-06 